Universidade de São Paulo

Faculdade de Filosofia, Letras e Ciências Humanas

Departamento de História

Programa de História Social

\title{
Solidariedade e Resistência em Tempos Sombrios: As associações judaicas no Estado de São Paulo (1937-1950)
}

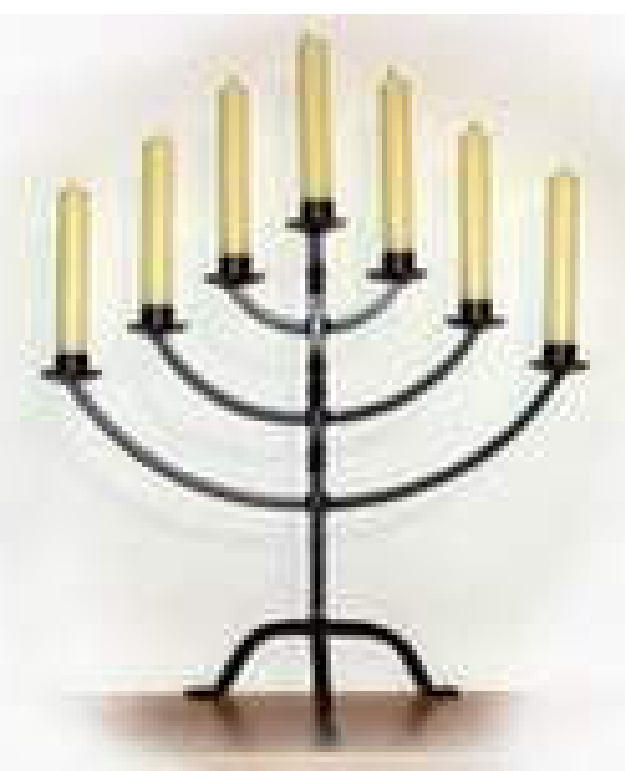

Dissertação de Mestrado em História Social

Autora: Renata Mazzeo Barbosa

Orientadora: $\operatorname{Prof}^{\mathrm{a}} \mathrm{Dr}^{\mathrm{a}}$ Maria Luiza Tucci Carneiro

São Paulo

2008 
Universidade de São Paulo

Faculdade de Filosofia, Letras e Ciências Humanas

Departamento de História

Programa de História Social

\section{Solidariedade e Resistência em Tempos Sombrios:
As associações judaicas no Estado de São Paulo Tempos Sombrios:
As associações judaicas no Estado de São Paulo (1937-1950)} . 


\section{Sumário}

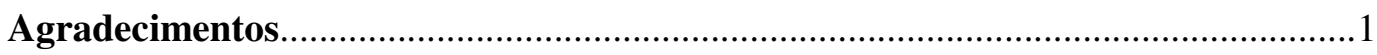

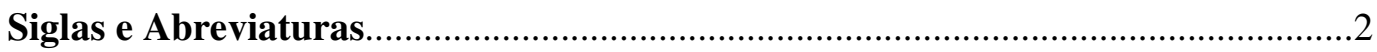

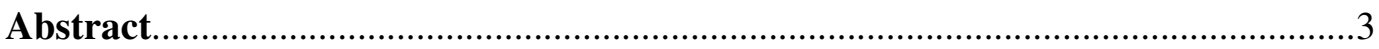

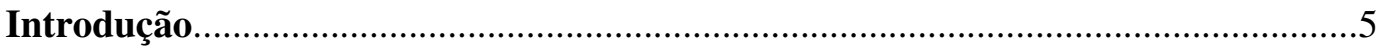

I. Aspectos do judaísmo no Brasil Contemporâneo

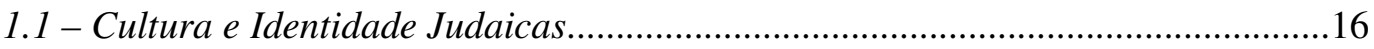

1.2 - Fascismo, intolerância e emigração forçada .....................................................25

1.3 - As Associações comunitárias e as estratégias de ajuda aos refugiados...............33

II. Frentes de resistência ao Nazi-fascismo

2.1 - Congregação Israelita Paulista: Ação e Solidariedade ........................................40

2.2 - As Crianças e os Jovens da Congregação Israelita...............................................71

\section{Redes de Solidariedade}

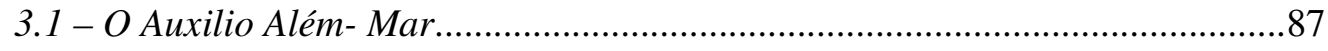

3.2 - O JOINT, a Congregação Israelita Paulista e os Emigrantes........................109

\section{A Comunidade e os Súditos do Eixo}

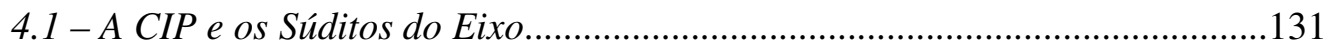

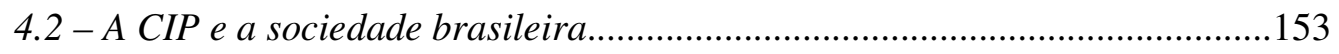

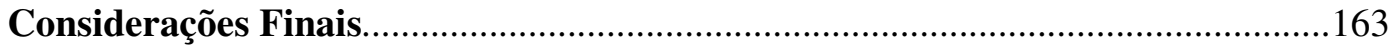

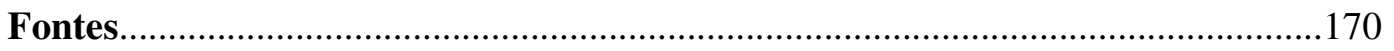

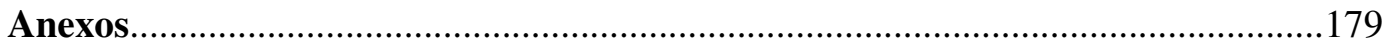

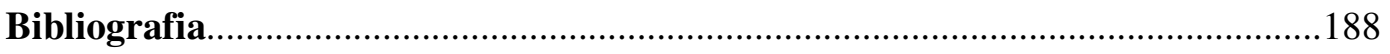




\section{Agradecimentos}

Inicialmente, agradeço à Professora Maria Luiza Tucci Carneiro por todos os conselhos, correções e, por toda a atenção e paciência com as quais tem me tratado ao longo desses anos. Desde os tempos de graduação, quando da Iniciação Cientifica, ela me ensinou o quanto a história poderia ser fantástica e surpreendente. No mestrado, possibilitou que eu tivesse acesso ao Arquivo Lorch, depositando em mim sua confiança. À Rachel Mizrahi, pelos "toques”, empréstimo de material e conversas sobre os conceitos judaicos e os caminhos a serem seguidos nesta pesquisa. Membro importante de minha banca de qualificação, a Professora Nancy Rosenchan chamou minha atenção para erros de conceituação e escrita.

Aos meus maravilhosos pais, pela convivência diária e compreensão por todas as vezes em que estive mal-humorada e impaciente com a finalização dessa dissertação. Nesses anos, eles me pouparam de muitas dificuldades e percalços, tomando para a si responsabilidades que anteriormente eram minhas. Ao meu querido e companheiro Edney Gualberto pela paciência e trocas de experiências.

Para que essa pesquisa tivesse conteúdo, foi importante a atenção e ajuda de Aparecido Oliveira e Tárcio Sandro, ambos funcionários do Arquivo Público do Estado de São Paulo. Agradeço também à Mirela e à Lúcia, responsáveis pela documentação existente no Arquivo Histórico Judaico Brasileiro.

À Família Lorch, pela compreensão da importância da reconstrução dos fatos históricos e pelo desprendimento que possibilitaram a doação do arquivo pessoal do Dr. Ludwig Lorch, personagem-chave do cenário judaico-paulistano entre as décadas de 1930 e 1940. Esses documentos se mostraram imprescindíveis e determinantes para a concretização desse trabalho. Ao Professor Celso Lafer, intermediário entre a Família Lorch e Tucci Carneiro, personagem importante que possibilitou que esse material chegasse ao conhecimento da história. 


\section{Siglas e Abreviaturas}

A.H.J.B - Arquivo Histórico Judaico Brasileiro

APESP - Arquivo Público do Estado de São Paulo

ARI - Associação Religiosa Israelita

CIC- Conselho de Imigração e Colonização

CIP - Congregação Israelita Paulista

DEIP - Departamento Estadual de Imprensa e Propaganda

DEOPS/SP - Departamento Estadual de Ordem Política e Social/São Paulo

EZRA - Sociedade Beneficente Amigos dos Pobres Ezra

HIAS - Hebrew Immigrant Aid Society

ICA - JCA - Jewish Colonization Association

JOINT - American Jewish JOINT Distribution Committe.

LEER/USP - Laboratório de Estudos sobre Etnicidade, Racismo e Discriminação

UNIÃO - Associação Beneficente Israelita do Rio de Janeiro 


\section{RESUMO}

As décadas de 1930-40 causaram uma grande transformação, em nível mundial, na comunidade judaica. Fuga da Europa hitlerista, holocausto e criação do Estado de Israel foram alguns dos acontecimentos que refletiram mudanças na trajetória de toda a comunidade. A emigração forçada iniciada em 1933 gerou a busca por refúgios livres do anti-semitismo. $\mathrm{O}_{\text {ischuv }}{ }^{1}$ na Palestina, região sob o domínio do mandato inglês, não constituía uma opção devido ao regime de cotas à imigração judaica imposto naquele momento. Nessa ocasião, portanto, o Brasil era visto como um "porto seguro". No entanto, essa visão transformava-se em miragem assim que esses imigrantes chegavam ao país. Sem contar com a ajuda governamental, em muitos momentos anti-semita manifesta, esses israelitas se viram num território estranho, no qual não possuíam conhecimento da língua, emprego, abrigo ou referências. Esse vácuo deixado pelo governo foi preenchido pela comunidade judaica já estabelecida no país, que, preocupada em receber os recém-chegados reservava a si, a tarefa de ensinar o português, encontrar abrigo e encaminhar a um emprego. Solidariedade, preocupação com a manutenção da cultura, da identidade e da religião judaicas, além de manifestações políticas e ideológicas foram algumas das principais bandeiras levantadas pelas Associações Judaicas estabelecidas no Brasil durante as décadas de 1930-50.

\footnotetext{
${ }^{1}$ Nome dado à comunidade judaica estabelecida na Palestina antes da criação do Estado de Israel em 1948.
} 


\begin{abstract}
The decades of 1930 and 1940 caused a world scale transformation in the Jewish community. Escape from Hitler's Europe, holocaust and the creation of the State of Israel were some of the facts that changed the trajectory of all Jewish community. The forced emigration that started in 1933 generated the search for refuges free from the anti-semitism. The $i s c h u v^{2}$ in Palestine, region under the control of the English, was not an option for those people due to the regime of quotas to the Jewish immigration imposed at that moment. Thus, in this occasion Brazil was seen as a safe place. However, this view becomes a mirage as soon as those immigrants arrived in the country. Without counting on the help of the government, many times explicitly antiSemite, the Jews found themselves in a strange territory, in which they did not know the language, and they did not have a job, shelter or references. This gap left by the State was compensated by the Jewish community already established in the country, that was concerned about welcoming the newcomers and then took the responsibility of teaching them Portuguese, finding shelter and referring to a job. Solidarity, concern about the sustenance of Jewish culture, identity and religion, besides the political and ideological manifestations were some of the main flags risen by the Jewish Associations established in Brazil from the decade of 1930 to 1950.
\end{abstract}

\footnotetext{
${ }^{2}$ Name given to the Jewish community established in Palestine before the creation of the State of Israel in 1948.
} 


\section{INTRODUÇÃO}

Com a promulgação da Constituição Brasileira de 1934 que instituiu o sistema de quotas para a imigração, e a adoção de Circulares Secretas a partir de 1937, podemos afirmar que os ideais racistas transformaram-se em política de Estado no Brasil. Circulando nos bastidores do Itamaraty e dos demais órgãos oficiais ${ }^{3}$, o discurso antisemita atendia aos interesses da elite política, muitas vezes simpática às propostas nazifascistas. Usavam com pretexto as tradicionais acusações de que os judeus dedicavamse apenas ao comércio nas capitais em detrimento da agricultura, além de não serem passíveis de assimilação. A partir de 1934, o Estado Nacional investiu contra os japoneses, negros e judeus tratando-os, cada vez mais, como indesejáveis.

Com a aplicação das Circulares Secretas, a religião judaica transformou-se em sinônimo de raça e nacionalidade, dando margens para que no Brasil, assim como nos países ocupados pelos nazistas, proliferassem o mito ariano e o mito do complô judaicointernacional. Sob este aspecto o judeu era freqüentemente associado às raças inferiores e ao comunismo ${ }^{4}$. Neste contexto, a ciência moderna se prestava para legitimar o estigma do judeu como raça inferior; enquanto no âmbito do político ele era interpretado como uma ameaça real à segurança nacional. A conexão da imagem do judeu ao ideário comunista, como se aquele fosse um disseminador de idéias subversivas, favoreceu ações intolerantes por parte do Estado e de alguns segmentos da sociedade brasileira.

Diante desta constatação, se faz necessário reconstituir alguns elementos expressivos da proliferação do anti-semitismo na Alemanha, tumultuada após a ascensão de Adolf Hitler ao poder em 1933. Após essa data, o Terceiro Reich implantou, através do nacional-socialismo, o plano de extermínio do povo judeu. O agravamento da perseguição empreendida aos judeus alemães e de outras nacionalidades do Leste europeu gerou um grande fluxo emigratório, intensificado, cada vez mais, a partir de 1937. Num momento de represália anti-semita sem limites, a vida de milhões de judeus passou a depender de um visto para emigrar, conquistado, muitas vezes, através das redes de solidariedade arregimentadas pelas comunidades judaicas

\footnotetext{
${ }^{3}$ Circulares Secretas ns ${ }^{\circ}$ 1.127, 1.261 e 1.249, apud Maria Luiza Tucci Carneiro. O Anti-semitismo na Era Vargas: Fantasmas de uma Geração, (1930-1945). $3^{\circ}$ ed. São Paulo: Perspectiva, 2001; O Veneno da Serpente. Reflexões sobre o Anti-semitismo no Brasil. São Paulo: Perspectiva, 2003.

4 Taciana Wiazovski. Bolchevismo e Judaísmo, A Comunidade Judaica sob o Olhar do DEOPS; Módulo VI - Comunistas. São Paulo: Arquivo do Estado/Imprensa Oficial, 2001.
} 
sediadas na Europa e seus núcleos receptores nas Américas. Neste mesmo ano, o governo brasileiro promulgava a primeira de muitas circulares secretas, através da qual sustentou uma política anti-semita. ${ }^{5}$

Se o recrudescimento do anti-semitismo na Alemanha forçou os judeus a emigrarem, a adoção de circulares secretas anti-semitas, pelo governo brasileiro, impediu o ingresso de milhares israelitas que não contavam com a ajuda das associações de sua comunidade. A maioria dos refugiados judeus que conseguiam desembarcar em terras brasileiras portava, apenas, o visto de turista. Mal conseguiam se comunicar com os brasileiros, dispunham de poucas oportunidades de emprego e muitos enfrentavam situações de miséria durante os primeiros meses no Brasil. Restava-lhes apenas a solidariedade da comunidade judaica radicada no país desde o final do século XIX. Cientes das necessidades desses refugiados, inúmeros foram os israelitas que estabelecidos em diferentes capitais brasileiras se preocuparam com o salvamento e adaptação desse grupo que, muitas vezes, portava passaporte de apátridas. Liderados pelos mais velhos uniram-se em associações com o intuito de ajudar aqueles que haviam conseguido o "visto da salvação", como atestam ainda hoje, alguns sobreviventes do nazi-fascismo. Tal atitude serviu também para fortalecer a identidade e os laços judaicos preservados através de sua religião e cultura.

A formação de associações judaicas de ajuda-mútua no Brasil - cuja expressividade só foi alcançada após 1938, em decorrência do início da Segunda Guerra Mundial - deve ser compreendida como um fenômeno constante na história do povo judeu na Diáspora. É necessário salientar que os judeus carregam sobre si uma história milenar delineada pela segregação e discriminação de seu povo. Esse aspecto peculiar de sua trajetória influenciou na reorganização das comunidades judaicas, no exílio, dedicadas a preservar a identidade do grupo. Muitas vezes, ao enfatizar os fatos históricos que a diferencia dos demais imigrantes, a comunidade judaica minimiza seus atos salvacionistas deixando-se ofuscar pelas versões divulgadas pela História Oficial. Cabe aqui lembrar a corrente exaltação ao Brasil enquanto país hospitaleiro e humanitário. Muitos fazem "vista grossa” à política anti-semita do governo Vargas que, em nenhum momento, investiu no salvamento dos judeus perseguidos na Europa ${ }^{6}$.

\footnotetext{
${ }^{5}$ Circular $n^{\circ}$ 1127, apud Maria Luiza Tucci Carneiro. O Anti-semitismo na Era Vargas: Fantasmas de uma Geração, (1930-1945), Op.cit.

${ }^{6}$ Sobre este tema e as políticas anti-semitas adotadas por países das América do Sul e Central, ver Maria Luiza Tucci Carneiro (org.). O anti-semitismo nas Américas. História e Memória. São Paulo: Edusp, FAPESP, 2008.
} 
Nesse contexto, a identidade judaica constituiu-se em elemento imprescindível para a inserção dos judeus refugiados junto aos seus iguais. Foram as associações, enquanto frentes de assistência, que lhes forneceram as condições para conquistar melhores condições de trabalho e oportunidades de vida na conjuntura econômica brasileira.

Tendo em vista tais elementos identitários optamos por estudar as redes de solidariedade que uniram as associações judaicas atuantes no Estado de São Paulo em prol de uma causa comum. Políticos ou estritamente assistenciais, diferenciados por seus objetivos, estes grupos favoreceram em grande parte, a unidade da comunidade, ainda que distintas por seus núcleos de origem e espaços de recepção. Enfim, consideramos que as rezas, as festas, as músicas, os jogos e o teatro judaicos transformaram-se em estratégias de sobrevivência do povo judeu na Diáspora. Avaliando a postura humanitária desta comunidade, constatamos que suas organizações se constituíram em verdadeiras "ilhas de tolerância" que, na sua maioria, sobreviveram ao anti-semitismo político inerente ao governo de Getúlio Vargas (1930-1945) e Eurico Gaspar Dutra (1946-1950).

As correntes imigratórias dos refugiados entre 1933 e 1948, devem ser compreendidas no contexto das redes de solidariedade envolvidas com o processo de salvamento dos judeus perseguidos pelos nacional-socialistas. A reconstituição das práticas das circulares secretas que proibiam a concessão de vistos aos semitas interessados em ingressar no Brasil, se faz necessária para avaliarmos a real dimensão do trabalho de resgate realizado pelas entidades judaicas.

Como recorte temporal, optamos pelo ano de 1937 até o início da década de 1950, abrangendo o período do Estado Novo (1937-1945) e o governo Dutra (19461950). Em 1937 a implantação do Estado Novo garantiu, por seu viés autoritário, a prática sistemática das circulares anti-semitas que, durante a Segunda Guerra Mundial, forçaram a criação de organizações dedicadas a salvar judeus refugiados e a abrigar os deslocados de guerra. O governo Dutra, da mesma forma que outros governos de países americanos, teve de enfrentar o grande fluxo de judeus sobreviventes dos campos de concentração na Europa. Após 1945, apesar da divulgação dos "campos da morte", o governo brasileiro pouco fez para oferecer abrigo aos sobreviventes sem pátria. Muitas vidas foram salvas graças à união das comunidades judaicas atuantes em todo o mundo, cujos contatos permitiram a localização de parentes e vitimas do nazismo, o reencontro com seus familiares e amigos sobreviventes, assim como o reinicio de uma nova vida. Com o estabelecimento do Estado de Israel em 1948, os israelitas radicados no Brasil 
puderam enfim, fortalecer sua noção de pátria em função da instalação de uma representação diplomática, até então inexistente ${ }^{7}$.

Importante ressaltar que nas décadas de 1940-1950, a comunidade judaica foi marcada pela ebulição de um conjunto de ideologias identificadas com a luta antifascista e a criação de um Lar Nacional Judaico na Palestina. Cumpre investigar o papel assumido pelo assistencialismo. Daí a importância de reconstituirmos a atuação dos imigrantes judeus de primeira geração, provenientes da Europa e radicados no Brasil desde o início do século XX. Esta ação se faz distinta daquela assumida por seus filhos, muitos dos quais, nascidos e criados no Brasil.

Ao propormos este estudo pretendemos avaliar o processo de recepção e as negociações que permearam as relações entre os órgãos governamentais e as associações judaicas. Estaremos atentos ao período do Estado Novo, momento em que persistiu a vigilância e a perseguição sistemáticas aos núcleos israelitas por parte da Polícia Política do Estado de São Paulo. Detentora de poder de decisão e mobilizada pelo mito do complô judaico-internacional, esta polícia agiu no sentido de coibir a ação das associações judaicas, mesmo daquelas dedicadas apenas ao assistencialismo. Nesse contexto de autoritarismo e xenofobia, não podemos desconsiderar a suspensão das atividades sionistas e o conseqüente fechamento ou reformulação dessas organizações a partir do Decreto-lei $\mathrm{n}^{\circ} .383$ que proibia aos estrangeiros fixados no território nacional e aos que nele se encontrassem em caráter temporário, a organização e a manutenção de sociedades, fundações, companhias, clubes e quaisquer outros estabelecimentos de caráter político. $^{8}$

O fim da ditadura de Getúlio Vargas não garantiu o início de uma paz duradoura para a coletividade judaica no Brasil que, acuada pelo medo e por insegurança, manteve-se fechada sobre si mesma. $\mathrm{O}$ volume de documentos policiais (prontuários e dossiês), referentes ao controle de suas associações, demonstra a persistência de uma posição arbitrária e intolerante em relação aos judeus, mesmo durante o governo Dutra. Daí a importância de avaliarmos a formação de associações judaicas que, a partir de 1937, contribuíram para a solidificação das redes de solidariedade, para o fortalecimento da identidade judaica, para a disseminação dos ideais sionistas e para a

\footnotetext{
${ }^{7}$ Em julho de 1948, Samuel Malamud foi nomeado Oficial de Ligação entre o Brasil e o recém-criado Estado de Israel. A instalação da Legação de Israel só ocorreu em 1952, com a vinda do primeiro representante diplomático, o General David Shaltiel.

${ }^{8}$ Decreto-lei $n^{\circ} 383$ de 18 de abril de 1938: Veda a estrangeiros a atividade política no Brasil e dá outras providências.
} 
sustentação de ajuda aos recém-chegados em Israel. O acervo do Arquivo Histórico Judaico-Brasileiro, no qual estão presentes as atas e as resoluções das principais reuniões ocorridas nas sedes das associações judaicas, fornece uma visita interessante ao olhar dos membros da comunidade sobre a legislação brasileira, as práticas governamentais e os acontecimentos externos. A documentação inédita do Arquivo Lorch traz à tona rascunhos e documentos confidenciais, referentes à CIP, portados por Ludwig Lorch e sua esposa Luiza ${ }^{9}$, o que nos possibilita conhecer toda a movimentação presente nos bastidores dessa importante associação. Cartas trocadas entre a CIP e o JOINT, nos auxiliarão a reconstituir os caminhos trilhados, com muita dificuldade, pelos judeus do pós-guerra. Sob o prisma da violência institucionalizada, os documentos produzidos pelo DEOPS/SP explicitam a força policial como um entreposto acionado para fragilizar a ação dessas associações enquanto frentes de resistência do povo judeu na Diáspora.

\section{A Historiografia sobre o Tema}

A historiografia contemporânea tem demonstrado que, a partir de 1933, milhares de judeus abandonaram a Europa Central e que, os sobreviventes do Holocausto, após a Segunda Grande Guerra, procuravam lugares nas Américas para recomeçar a vida ${ }^{10}$.

Essas ondas imigratórias e seus aspectos políticos têm sido, principalmente nas duas últimas décadas, objeto de atenção da historiografia brasileira. A obra pioneira $O$ Anti-semitismo na Era Vargas, de Maria Luiza Tucci Carneiro, norteou a partir de 1988, as pesquisas subseqüentes instigando novas pesquisas e abrindo o debate sobre o antisemitismo político e a política imigratória instituída pelo governo de Getúlio Vargas (1937-1945). Através de farta documentação diplomática, periódicos, charges e testemunhos orais, a autora comprova a aversão aos judeus expressa pelo alto escalão do governo, responsável pela emissão e prática de circulares secretas, além da imposição de quotas à imigração seletiva ${ }^{11}$.

Nessa mesma linha de pesquisa está o brasilianista Jeffrey Lesser cujo estudo dá continuidade aos temas pesquisados por Tucci Carneiro. $\mathrm{O}$ autor aprofunda a discussão

\footnotetext{
${ }^{9}$ O casal Lorch participou ativamente da formação das associações judaico-paulistanas mais importantes durante o governo de GetúlioVargas. Entre elas cito OFIDAS, CIP e Lar da Criança Israelita. Ludwig Lorch era médico e presidiu a CIP entre 1936-1941. Foi Presidente do Conselho entre 1942 e 1943.

${ }^{10}$ Maria Luiza Tucci Carneiro (org). O Anti-semitismo nas Américas, Op.cit.

${ }^{11}$ Maria Luiza Tucci Carneiro. O Anti-semitismo na Era Vargas, Op.cit.
} 
em temas como a prática das circulares secretas e o trajeto dos refugiados a bordo do navio Cabo de Hornos. Publicado em 1995, o estudo de Lesser retoma os três eixos investigados por Tucci Carneiro: diplomacia, imigração e anti-semitismo, procurando minimizar o envolvimento de Oswaldo Aranha, Ministro das Relações Exteriores entre 1937-1944, apresentando-o como filo-americanista. Comprovar a entrada legal de 4.601 imigrantes judeus no ano de 1939, considerando as medidas "oficiais" para impedir a entrada de "indesejáveis" da raça semita, constitui uma das principais preocupações manifestadas pelo autor. Segundo Lesser, os estereótipos negativos aos judeus foram, naquele momento, positivamente reinterpretados, fato que teria influenciado para a aceitação, ainda que parcial, do judeu no Brasil ${ }^{12}$. O estudo retoma a análise do antisemitismo varguista no sentido de demonstrar o endosso deste em alguns círculos do alto escalão e sua inexistência na sociedade brasileira ${ }^{13}$.

Esta temática foi retomada por Avraham Milgran que, em 1995, publicou Os Judeus do Vaticano, obra que trata das políticas anti-imigratórias varguistas e as dificuldades criadas por estas para a entrada de judeus, convertidos ao cristianismo, em território nacional. $\mathrm{O}$ autor tem como objeto da sua pesquisa a autorização de Getúlio Vargas para a concessão de 3.000 vistos de entrada no Brasil para alemães católicos não arianos, em consideração à solicitação feita pelo Papa Pio XII ${ }^{14}$. A partir daí, Milgran nos mostra as maquinações do governo brasileiro para que tal promessa não precisasse ser cumprida, como de fato não foi. Na sua totalidade, dos 3.000 vistos pedidos, apenas 959 foram outorgados ${ }^{15}$.

Mais recentemente, Taciana Wiazovski, utilizando-se de documentos inéditos do acervo DEOPS, demonstrou como o anticomunismo e o anti-semitismo eram sentimentos que caminhavam juntos nas décadas de 1930-1940 ${ }^{16}$. Através da análise de impressos católicos, Wiazovski esclarece como a Igreja Católica esteve envolvida na

\footnotetext{
${ }^{12}$ Por exemplo, a imagem estereotipada do judeu capitalista foi repensada pela liderança brasileira a partir de conceitos desenvolvimentistas da época, nos quais tanto a capacidade engenhosa da iniciativa privada como seu capital, faziam-se necessários.

13 Jeffrey Lesser. O Brasil e a Questão Judaica. Rio de Janeiro: Imago, 1995.

${ }^{14}$ Esta questão foi tratada pela primeira vez, no livro de Tucci Carneiro, O Anti-semitismo na Era Vargas (1930-1945), num sub-ítem específico que leva o nome de "Novos-Cristãos do Século XX", cujo conteúdo faz uma analogia ao episódio dos cristãos-novos perseguidos pela Inquisição Ibérica na época moderna.

${ }^{15}$ Avraham Milgran, Os judeus do Vaticano. Rio de Janeiro: Imago, 1994.

16 Taciana Wiazovski,O Mito do Complô Judaico-Comunista no Pensamento Autoritário Brasileiro: Gênese, Difusão e Desdobramentos. Dissertação de Mestrado apresentada ao Programa de Pós em Língua Hebraica, Literatura e Cultura Judaicas. FFLCH / USP, 2005.
} 
construção de uma imagem estereotipada do israelita radicado no Brasil, associando-o ao comunismo e a proliferação da obra apócrifa Os Protocolos dos Sábios de Sião ${ }^{17}$.

Na contramão das obras citadas até aqui, encontramos A Questão Judaica Diplomacia, Repressão e Resistência no Brasil Contemporâneo, de Zilda Iokói, que sustenta a tese de que os judeus estabelecidos no Brasil à época de Vargas e Dutra eram realmente comunistas e, por este motivo, sofreram perseguições por parte da Polícia Política. Ignorando os milhares de documentos anti-semitas produzidos pela diplomacia e autoridades brasileiras, a autora explicita que “(...) em nenhum documento é possível afirmar que estariam esses representantes do poder do Estado formulando uma política anti-semita". ${ }^{18}$ Em outra passagem, Zilda Iokói associa a intolerância aos judeus com a sua participação em meios comunistas:

“(...) percebemos que havia um certo movimento de tolerância aos judeus quando eles não estavam ligados ao comunismo, ao programa revolucionário e às práticas desenvolvidas pela Internacional Comunista." ${ }^{19}$

Ou seja, o anti-semitismo não existira, mas apenas o já conhecido preconceito anticomunista que recaía sobre a comunidade judaica devido à sua tendência esquerdista.

Em seu livro D. Quixote nas Trevas, o historiador Fábio Koifman relata em primeiro plano, o trabalho e o salvamento de centenas de judeus realizado pelo embaixador brasileiro Luiz Martins de Souza Dantas, Chefe da Representação Brasileira na França de 1922 a 1943. Os cenários para essa história são o Holocausto e as diretrizes da política externa ditadas pelo Presidente brasileiro Getúlio Vargas, com o objetivo de impedir a entrada de determinados grupos imigrantes em território nacional, dentre os quais os "semitas". Cruzando pesquisa histórica com testemunhos, Koifman descobriu que o Embaixador Dantas não se limitava "a dar vistos", conseguindo, muitas

\footnotetext{
${ }^{17}$ Inspirada na obra de Sergey Nilus, do final do século XIX, que recompõe o diálogo entre Maquiavel e Montesquieu no inferno, a primeira versão dos Protocolos (Rússia, 1903), não tem autoria definida e, tentava comprovar a existência de uma organização de anciãos judeus com pretensões de dominar o mundo. No Brasil, a primeira edição em português dos Protocolos, data de 1936, traduzida por Gustavo Barroso.

${ }^{18}$ Zilda Márcia Grícoli Iokói A Questão Judaica. Diplomacia, Repressão e Resistência no Brasil Contemporâneo. Tese de Livre Docência apresentada ao Departamento de História: FFLCH / USP, 2001, publicada pela Associação Editorial Humanitas em parceria com o LEI/USP (Laboratório de Estudos da Intolerância), em 2004. p.114.

${ }^{19}$ Ibid. p.116.
} 
vezes, documentos de viagem através de conhecidos em outras representações diplomáticas, como os cônsules de Cádiz, na Espanha, e Casablanca, no Marrocos ${ }^{20}$.

Convergindo ou não, o ponto comum entre esses estudos está no enfoque político do anti-semitismo enquanto instrumento de poder. Tanto Tucci, como Lesser e Wiazovski, avaliam as ações anti-semitas governamentais e eclesiásticas com ênfase nas restrições legais e secretas impostas pelo governo Vargas. Nesse contexto, a comunidade judaica nos parece vitimizada, sujeita a tais imposições e com poucas condições materiais e psicológicas para reagir enquanto frentes de resistência. Tal postura é ainda pouco conhecida pela historiografia brasileira, que tem dificuldades para acessar os arquivos da comunidade judaica. Ainda por inventariar e, bastante dispersos, os documentos carecem de maior atenção por parte dos arquivistas, historiadores e líderes comunitários. Mesmo porque a divulgação de registros da comunidade judaica à época da Segunda Guerra e no pós-guerra, permanece restrita aos livros comemorativos $^{21}$, e obras biográficas de algumas de suas personalidades ${ }^{22}$.

No trato da comunidade judaica como um todo, destaco as obras de Nachman Falbel Estudos sobre a Comunidade Judaica no Brasil. ${ }^{23}$, Egon e Frieda Wolff Depoimentos: Um Perfil da Coletividade Judaica Brasileira ${ }^{24}$, Henrique Rattner Tradição de Mudança. A Comunidade Judaica em São Paulo ${ }^{25}$, Alice Irene Hisrschberg, Desafio e Resposta, a História da Congregação Israelita Paulista ${ }^{26}$ e Roney Cytrynowicz, Unibes 85 anos. Uma História de Trabalho Social da Comunidade

\footnotetext{
${ }^{20}$ Fábio Koifman. Dom Quixote nas Trevas. Rio de Janeiro: Imago, 2000.

${ }^{21}$ Entre esses podemos citar: 40 aniversário da Sociedade de Beneficência Israelita EZRA. São Paulo, 1956; Alice Irene Hirschberg, Desafio e Resposta, a História da Congregação Israelita Paulista, Edição especial por ocasião do quadragenário da Congregação Israelita Paulista, São Paulo, 1976; Unibes 85 anos. Uma história de trabalho social da comunidade judaica em São Paulo. São Paulo, 2001; Renascença 75 anos; Comemorativo ao aniversário do Instituto de Educação Hebraico Brasileiro Renascença. São Paulo, 1997; Fisesp 50 anos. Comemorativo ao aniversário da Federação Israelita de São Paulo. São Paulo, 1996; Bnai Brith do Brasil: 70 anos de intenso trabalho em defesa dos direitos do homem. Revista Herança Judaica $\mathrm{n}^{\circ}$ 111; A Congregação Israelita dos Pequenos. História do Lar das Crianças da Congregação Israelita Paulista - 65 anos. São Paulo, 2003.

22 Fritz Pinkuss, Estudar, Ensinar, Ajudar - Seis décadas de um rabino em dois continentes. São Paulo: Cultura, 1990; Lívio Túlio Pincherle, Meus dois Mundos: História da vida de médico judeu ítalobrasileiro. São Paulo: Roswitha Kempf, 1987; Nelson Werneck Sodré, Memórias de um Escritor -1. Rio de Janeiro: Civilização Brasileira, 1970; Marília Freidenson e Gaby Becker (org.) Passagem para a América. Relatos da Imigração Judaica para São Paulo. São Paulo: Arquivo do Estado / Imprensa Oficial, 2003.

${ }^{23}$ Nachman Falbel. Estudos sobre a Comunidade Judaica no Brasil. São Paulo, Federação Israelita do Estado de São Paulo, 1984

${ }^{24}$ Egon e Frieda Wolff. Depoimentos: Um Perfil da Coletividade Judaica Brasileira. Rio de Janeiro, Instituto Histórico e Geográfico Brasileiro, 1988.

${ }^{25}$ Henrique Rattner Tradição de Mudança. A Comunidade Judaica em São Paulo. São Paulo, Ática, 1977.

${ }^{26}$ Alice Irene Hirschberg, Desafio e Resposta, a História da Congregação Israelita Paulista. Op.cit.
} 
Judaica em São Paulo; A Congregação Israelita dos Pequenos: História do Lar das Crianças da Congregação Israelita Paulista, 65 anos; Guerra sem Guerra. ${ }^{27}$.

Tradição e Mudança constitui uma das obras de maior relevância acerca da história da comunidade judaica em São Paulo. Através de estatísticas precisas, Henrique Rattner avalia importantes meandros da vivência judaica contemporânea no Estado de São Paulo na década de 1970. A inserção econômica do imigrante judeu é um dos pontos centrais da sua análise dedicada a reconstituir o status sócio econômico dos imigrantes judeus e de seus descendentes. Tal preocupação corresponde à sua formação acadêmica em Economia Política, e sua abordagem enquanto personagem desta imigração. No entanto, tal estudo não abrange a comunidade judaica de primeira geração, imigrantes e refugiados que chegaram ao nosso país num momento difícil.

Por dedicar-se ao surgimento das associações judaicas no Brasil, Nachman Falbel utiliza em seu estudo um balizamento que se estende do período colonial até o Brasil Império, centrando-se no decorrer do século XIX e no primeiro quarto do século XX. A contribuição dos judeus paulistas ao desenvolvimento de São Paulo desde os tempos coloniais até o início do século XX, o primeiro Congresso Sionista no Brasil em 1922 e a presença israelita na Revolução Paulista de 1932, são alguns dos pontos explorados pelo autor.

Os testemunhos constituem o ponto de partida para Depoimentos, do casal Egon e Frieda Wolff. A obra apresenta uma compilação de cerca de vinte depoimentos de judeus radicados no Brasil, principalmente no Rio de Janeiro e São Paulo, considerando suas origens e percepções acerca do território brasileiro, no momento da sua imigração. A trajetória de vida desses depoentes no Brasil também é valorizada pelos autores. Apesar de ser uma importante fonte de conhecimento sobre a percepção e o entrosamento judaicos dispensados ao Brasil, o livro não traz uma análise mais aprofundada acerca dessas memórias.

Em Desafio e Resposta, Alice Irene Hirschberg procura reconstituir a memória da Congregação Israelita Paulista, importante associação judaica fundada em 1936, por um grupo de imigrantes judeus da Alemanha. Por se tratar de um livro comemorativo, escrito por uma figura atuante nessa instituição, a autora lega à obra um tom propagandístico, no qual exalta não só os feitos da CIP, mas também a superioridade

\footnotetext{
${ }^{27}$ Roney Cytrynowicz. Unibes 85 anos, Op.cit.; A Congregação Israelita dos Pequenos; Op.cit.; Guerra sem Guerra. A mobilização e o cotidiano de São Paulo durante a Segunda Guerra Mundial. São Paulo: Edusp, 2000.
} 
dos judeus de origem alemã: “o judeu alemão representava um tipo especial, diferente do judeu que comumente dominava o cenário, isto é, o judeu europeu ocidental (...) no ano seguinte, a família Lorch, conjugando o ambiente de sofisticação dos judeus já estabelecidos com a cultura característica judaica-alemã." 28 Apesar de ter sido elaborado a partir de fontes históricas - como alguns periódicos da imprensa judaica - e documentação referente ao desenvolvimento da Congregação, a obra de Alice Irene não se diferencia dos outros livros comemorativos escritos por pessoas contratadas pelas respectivas comunidades. Além disso, Alice é filha de Alfred Hirschberg, colaborador da CIP e editor do periódico Crônica Israelita, produzido por essa associação. Deste modo, a autora não consegue escapar de colocações tendenciosas.

Nessa mesma linha dos livros comemorativos, encontramos Roney Cytrynowicz, autor de várias obras sobre a história das principais associações judaico-paulistanas, como a UNIBES e o Lar da Criança Israelita ${ }^{29}$. Estes estudos descrevem como tais organizações foram formadas, suas linhas de atuação, os problemas enfrentados durante sua trajetória e os sucessos conquistados. Valendo-se de fontes primárias, Cytrynowicz procura contextualizar o trabalho daquelas associações em um universo mais amplo. $\mathrm{O}$ autor realiza uma análise menos parcial dos documentos textuais, cruzando-os com a iconografia e entrevistas expressivas da história da comunidade judaica em São Paulo. Em meio acadêmico, Cytrynowicz analisou em sua dissertação de mestrado o antisemitismo e o integralismo nos textos de Gustavo Barroso durante os anos 30, recuperando os principais temas de seus livros e artigos escritos durante a existência do partido integralista, entre 1932 e $1937^{30}$. A pesquisa identifica o anti-semitismo e o mito da conspiração judaica mundial como temas centrais para a compreensão do pensamento de Barroso e sua concepção de história. Em 2000, o autor publicou sua tese de doutorado, "Guerra sem Guerra. A mobilização e o cotidiano de São Paulo durante a Segunda Guerra Mundial”, retratando o dia-a-dia e a consciência adquirida pela população paulistana durante a Segunda Grande Guerra ${ }^{31}$. Este estudo, de caráter mais acadêmico, se utilizou de periódicos, jornais e obras literárias da época a fim de captar a

\footnotetext{
${ }^{28}$ Alice Irene Hisrschberg, Op.cit. p. 24-25.

${ }^{29}$ Roney Cytrynowicz. Unibes 85 anos. Uma História de Trabalho Social da Comunidade Judaica em São Paulo; A Congregação Israelita dos Pequenos: História do Lar das Crianças da Congregação Israelita Paulista, 65 anos, Op.cit.

${ }^{30}$ Roney Cytrynowicz. Integralismo e anti-semitismo nos textos de Gustavo Barroso na década de 30. Dissertação de Mestrado apresentada ao Departamento da História da FFLCH/USP, 1992.

${ }^{31}$ Roney Cytrynowicz. Guerra sem Guerra. A mobilização e o cotidiano de São Paulo durante a Segunda Guerra Mundial, Op.cit.
} 
mentalidade paulistana durante a II Guerra. Aqui, a comunidade judaica foi brevemente citada, não constituindo o tema principal da obra.

Recentemente foi defendida a tese de doutorado In Difesa della Razza, por Ana Rosa Bigazzi que, baseada em ampla documentação do Arquivo Histórico do Itamaraty, reconstituiu a fuga e a trajetória dos judeus italianos radicados no Brasil a partir de $1938 . .^{32}$

Enfim, podemos afirmar que são poucos os estudos dedicados à reconstituição da trajetória dos sobreviventes do nazismo que conseguiram emigrar para o Brasil. Milhares de documentos sobre este tema continuam inéditos nos acervos públicos e comunitários brasileiros. O papel das redes de solidariedade que contribuíram para o salvamento de milhares de judeus refugiados na Europa a partir de 1933, ainda está por ser estudado. Ao investir na ajuda humanitária as comunidades judaicas organizadas no Brasil garantiram a sua continuidade e reforçaram de seus traços de identidade. Enquanto grupo de resistência ao nazi-fascismo, os judeus garantiram a preservação de sua cultura permeada por valores éticos, humanitários e de justiça difundidos pelo judaísmo. Enfim, a sobrevivência do judeu enquanto membro de um grupo distinto e historicamente hostilizado, lhe imprimia um sentimento profundo e intensamente arraigado de auto-defesa ${ }^{33}$. Estas são as questões que orientam este estudo ${ }^{34}$.

\footnotetext{
32 Anna Rosa Bigazzi In Difesa della Razza - Os judeus italianos refugiados do fascismo e o antisemitismo do Governo Vargas. Doutorado em Língua Hebraica, Literatura e Cultura Judaica; Departamento de Letras Orientais, FFLCH/USP, 2008.

${ }^{33}$ Silvia Jane Zveibil. Identidade Étnica judaica. Caracterização e Processo de Constituição. Tese de Doutorado apresentada ao Departamento de Ciências Sociais. FFLCH/USP, 1980.

${ }^{34}$ Em consonância com outros trabalhos orientados por Maria Luiza Tucci Carneiro, esse estudo integrará o Arquivo Virtual sobre o Holocausto e o Anti-semitismo (ARQSHOAH), que disponibilizará através da internet, o acesso inúmeros documentos, fontes primárias e entrevistas sobre as vicissitudes enfrentadas pela comunidade judaica no Brasil.
} 


\section{I - ASPECTOS DO JUDAISMO NO BRASIL CONTEMPORÂNEO}

\section{1 - Cultura e Identidade Judaicas}

A definição de identidade judaica é um problema cuja resolução tem sido tentada por diversos autores, muitos dos quais são judeus. $\mathrm{O}$ embate entre a acepção religiosa, cultural, étnica e histórica se apresenta na maioria destes trabalhos, o que nos induz a pensar o nosso objeto de estudo - as associações comunitárias - sob múltiplos vieses. É indubitável a peculiaridade da identificação dos judeus, o que possibilitou sua existência enquanto grupo distinto, por dois mil anos de Diáspora, sem que houvesse a ligação com um Estado Nacional. Inseridos em sociedades nas quais eram, muitas vezes, repudiados, os judeus resistiram aos caminhos da assimilação e da conversão, acreditando no possível retorno à Terra que, biblicamente, lhes havia sido prometida.

Dada a impossibilidade de se caracterizar o grupo judaico enquanto raça, já que tal definição prevê um complexo no qual se incluem características de origem genética, e considerando-se que a religião não é suficiente para a caracterização de um povo que criou um Estado-nação, utilizaremos aqui a definição de grupo étnico de Fredrik Barth para identificar socialmente os judeus. Este conceito atende ao nosso trabalho que se propõe a explicar a tendência centrípeta da comunidade judaica brasileira e a sua ação solidária.

Segundo Barth, um grupo étnico designa uma população que:

a) "Perpetua-se por meios biológicos;

b) Compartilha de valores culturais fundamentais, postos em prática em formas culturais;

c) Compõe um campo de comunicação e interação;

d) Tem um grupo de membros que se identifica e é identificado por outros como constituinte de uma categoria distinguível de outras categorias da mesma ordem." 35

Sob esse aspecto, a constituição de um grupo étnico não depende de qualidades raciais ou de referentes à origem nacional, mas é determinada por uma situação de interação social, na qual qualquer característica diferencial pode ser utilizada como instrumento para definição do grupo. Ou seja, a diferenciação entre os grupos tem como base as características religiosas, lingüísticas ou alimentares, construindo-se assim, as

\footnotetext{
${ }^{35}$ Fredrik Barth. Ethnic Groups Boundaries: The Social Organization of Culture Difference. Boston: Little Brown \&Co, 1969. p. 10-11.
} 
peculiaridades étnicas pela instituição dos limites entre os grupos: "na medida em que os agentes se valem da identidade étnica para classificar a si próprios e aos outros, para propósito de interação, eles formam grupos étnicos em seu sentido de organização" ${ }^{\text {36 }}$. Silvia Jane Zveibil, ao elaborar um estudo baseado em entrevistas com jovens judeus, conclui:

"É esta relação entre individuo e sociedade onde a identidade pessoal (ou individual) e social (ou coletiva) emerge (...) Isto é, que o ser judeu, surge da relação, das pessoas com a sociedade, não sendo portanto uma condição natural, mas construída socialmente" 37

Este processo depende, portanto, do contato interétnico, da existência de outros grupos que determinem uma situação de interação. Adentramos, pois, na essência da identidade étnica: a identidade contrastiva. Roberto Cardoso de Oliveira afirma que, "quando uma pessoa ou grupo se afirmam como tais, o fazem como meio de diferenciação em relação a alguma pessoa ou grupo com que se defrontam" ${ }^{38}$, ou seja, a identidade contrastiva surge por oposição e implica, principalmente, na afirmação de nós diante dos outros. Para Erwin Goffman, o fato de a identidade ser parte dos interesses e definições de outras pessoas em relação ao grupo ou ao individuo cuja identidade está em questão, constitui a base para a estigmatização desse mesmo grupo ${ }^{39}$. Nesse sentido, tais indivíduos seriam reféns da idéia que os considerados "normais" construíram sobre eles, não possuindo liberdade para definirem sua própria identidade.

Enquanto Goffman entende a identidade contrastiva como algo negativo, o autor Luís Luwisohn analisa as situações de segregação com relativa positividade, já que acredita viver num mundo onde as diferenças são essenciais para o crescimento humano. A massificação da cultura, dos costumes e das pessoas, constituiria uma característica típica de regimes totalitários, aos quais os indivíduos, em especial os judeus, não devem se render. Em texto dirigido à coletividade judaica brasileira, explica ser necessário diferenciar os judeus do restante da população, criticando abertamente o assimilacionismo. Acreditando que "ser judeu" não é uma escolha ou atribuição social, mas sim, o único destino possível para aqueles que possuem antepassados judeus, o

\footnotetext{
${ }^{36}$ Roberto Cardoso de Oliveira. Identidade, Etnia e Estrutura Social. São Paulo: Livraria Pioneira, 1976, p.4.

${ }^{37}$ Silvia Jane Zveibil, Op.cit, p. 58.

${ }^{38}$ Roberto Cardoso de Oliveira, Op.cit, p. 5.

${ }^{39}$ Irving Goffman. Estigma. Rio de Janeiro: Zahar Editores, 1980.
} 
autor clama pela democracia e pela liberdade inerente a essa, para que a comunidade judaica possa ser feliz "ao exibir o seu verdadeiro 'eu”. ${ }^{40}$

Importante salientar que os membros do grupo aproveitam sua identidade étnica como modo de estabelecer os limites e reforçar a solidariedade de seu grupo em relação aos demais, num processo em que eles próprios são identificados pelos outros. Segundo Goffman, "o seu grupo real, então, é o agregado de pessoas que provavelmente terão de sofrer as mesmas privações que ele sofreu porque tem o mesmo estigma"41. Aqui, a identidade por contraste é tratada não como algo natural, mas como uma consequiência do preconceito sustentado por certos segmentos sociais em relação a outros, principalmente as minorias.

Helena Lewin considera a endogamia, a solidariedade no exílio e o imperativo da memória, como os três pilares sobre os quais repousa a identidade judaica e sua perpetuação na Diáspora ${ }^{42}$. A endogamia constituiria a ferramenta de manutenção da integridade do grupo, de sua continuidade; enquanto o imperativo da memória significa lembrar dos ensinamentos divinos, contar e recontar a história judaica:

“A permanência judaica - pluriespacial e pluritemporal - decorre de sua memória e do compromisso de mantê-la servindo de fundamento para sua caracterização enquanto povo quer referida a seus antecedentes históricos - o passado, assim como a seus pares no presente e seus descendentes no futuro." 43

Já a solidariedade no exílio, tema deste nosso estudo, estaria relacionada ao momento após a destruição do segundo templo de Jerusalém ${ }^{44}$, símbolo da unidade nacional, o que incitou as comunidades dispersas no exílio a "se fechar" de modo a manter suas características culturais e religiosas. Assim, criou-se um sentimento de responsabilidade "que estimula cada judeu a ser responsável por si e pelos outros judeus. Este sentimento é responsável pela identidade judaica”,45.

Nesse sentido, grande parte das comunidades que convivem ao lado dos judeus, acreditam na tese do enquistamento da população judaica, argumento que tem se prestado para legitimar o anti-semitismo através do suposto comportamento "avesso"

\footnotetext{
${ }^{40}$ Luís Luwisohn. O Que é a Herança Judaica? Rio de Janeiro: Editora B'Nai B'rith, s/d, p. 19.

${ }^{41}$ Irving Goffman, Op.cit, p.124.

42 Ilana Rabinovici Iglicky. A Ética Judaica inserida no Sistema Educacional como fator construtor da Identidade Comunitária: Fatos e Realidades. Dissertação de Mestrado apresentada ao Programa de Pós em Língua Hebraica, Literatura e Cultura Judaicas. FFLCH / USP, 2004, p. 17.

${ }^{43}$ Helena Lewin. "Os Judeus e seu Compromisso com a Memória". Revista do Museu Judaico, Edição comemorativa do $25^{\circ}$ aniversário. Rio de Janeiro, julho de 2002, p.3.

${ }^{44} \mathrm{O}$ segundo Templo de Jerusalém, construído após o retorno do exílio imposto pelos babilônios, foi destruído pelos romanos em 70 d.C.

${ }^{45}$ Ilana Rabinovici Iglicky, Op. cit, p. 17.
} 
dos judeus. Assistimos ao início de um "círculo vicioso" no qual, o comportamento da comunidade judaica serve de base para a construção do discurso anti-semita que, por sua vez, provoca uma reação de auto-defesa, comportamento julgado inadequado.

Ilana Iglicky avança ainda mais na busca das raízes históricas da solidariedade judaica, relacionando-a ao recebimento da $\operatorname{Torá}^{46}$ por Moisés no Monte Sinai, cujo ensinamento incorre no cultivo da bondade, generosidade e responsabilidade coletiva. A partir daí, a autora analisa duas importantes instituições relacionadas à religião judaica, a guemilut chassadim e a tsedaká:

"O mandamento da guemilut chassadim inclui qualquer ato de bondade que é feito a outro, como emprestar dinheiro ou objeto, ser hospitaleiro, visitar e confortar doentes, dar roupas a quem necessita, auxiliar e alegrar noivos e noivas, enterrar os mortos e consolar os enlutados" ${ }^{\prime 7}$.

Traduzida como “caridade e honradez”, a tsedaká significa a obrigatoriedade da filantropia para todos os judeus, e pode ser considerada como um sinônimo de justiça social. Seus princípios estão intimamente relacionados à religião judaica, às noções de que todos os homens são iguais perante a Deus e, portanto, merecem ter as mesmas oportunidades e condições. Aos benefícios legados a todos os judeus pela sua pertença à comunidade deveria haver igual retribuição por aqueles que tivessem tais condições. Durante a antiguidade, "os sábios ensinavam que um judeu não deveria considerar esses deveres sociais como cargas, mas como outras formas de os homens mostrarem seu amor a Deus e sua honradez" ${ }^{\text {"48 }}$. Suas idéias já eram presentes no momento em que os judeus foram resgatados do Egito por Moisés, nos preceitos inscritos no Talmud e nas obras de Maimônides, segundo o qual "um judeu mantido à distância de sua comunidade, embora temente a Deus de outros modos, não teria participação no outro mundo ${ }^{, 49}$. Segundo a tsedaká, a prática de atos bondosos levaria àquele que os praticou a uma esfera mais próxima de Deus. Tais atos poderiam ser em forma de ajuda

\footnotetext{
${ }^{46}$ Torá é o nome dado aos cinco primeiros livros do Tanakh e que constituem o texto central do judaísmo. Contém os relatos sobre a criação do mundo, da origem da humanidade, do pacto de Deus com Abraão e seus filhos, e a libertação dos filhos de Israel do Egito e sua peregrinação de quarenta anos até a terra prometida. Inclui também os mandamentos e leis que teriam sido dadas a Moisés para que entregasse e ensinasse ao povo de Israel.

47 Ilana Rabinovici Iglicky, Op. cit, p.23.

${ }^{48}$ Paul Johnson. História dos Judeus. Rio de Janeiro, Imago, 1989, p.161.

${ }^{49}$ Nascido em 1135, numa família judaica, Maimônides, além de médico, estudou a tradição judaica com seu pai, juiz e erudito da jurisprudência legal judaica. Maimônides escreveu dez trabalhos de medicina em árabe e vários trabalhos de teor religioso, onde reflete sua visão filosófica sobre o judaísmo. É o codificador dos treze príncipios fundamentais do judaísmo. Morreu em 1204, em Fostat. Paul Johnson. Op.cit, p.161.
} 
financeira, afeto ou conhecimento, contanto que quaisquer necessidades de seu semelhante fossem supridas. A tsedaká seria, nesse sentido, uma atitude necessária para a construção de uma sociedade mais justa, contribuindo para a distribuição dos recursos de forma mais racional e menos desigual. "O judeu deve exercer esta prática da tsedaká no seu cotidiano e transmiti-la aos seus filhos através de seus atos, praticando a tsedaká com a doação de recursos ou através de trabalhos voluntários nas instituições. ${ }^{\circ 0}$. Ajudar aos necessitados, idosos e crianças, doentes e viúvas, além de providenciar hospedagem aos viajantes e sepultura aos mortos constituem, pois, algumas características da tsedaká. Adiante, veremos de que forma as associações beneficentes judaico-paulistanas agiram em congruência com os preceitos propostos pelas guemilut chassadim e tsedaká.

Sem a posse de um Estado Nacional com o qual pudessem se identificar, os judeus constituíram uma minoria étnica por toda a história da Diáspora. O passado de discriminação e anti-semitismo refletiu-se na forma como os judeus se organizaram e construíram sua história em meio à sociedade mais ampla. $\mathrm{O}$ ódio aos judeus iniciou-se já no mundo heleno pré-cristão, quando literários anti-semitas acusavam a comunidade judaica de sacrificar gregos no templo de Jerusalém; mais tarde, após o século quarto, a Igreja Católica adotou o mundo greco-romano e o rancor pagão, contribuindo para a inserção desses valores na mentalidade ocidental. A partir daí, os judeus passaram a ser vistos como "seres que odiavam a humanidade" 51.

Durante a Idade Média, a economia comercial e os preconceitos cristãos empurraram os judeus às ocupações impopulares, como traficantes e agiotas. Discriminados como portadores de sangue infecto, os judeus eram acusados de serem os responsáveis pela peste negra que varria o século XIV, sendo classificados como envenenadores de poços e feiticeiros, conspirando contra os cristãos. A perseguição aos judeus transformou-os num povo migrante, sem direito a possuir terras e restrito aos ofícios mais sórdidos, posição que acentuou sua tendência à exclusividade.

No contexto iluminista, os judeus da Europa Central e Ocidental, puderam então, conviver com os demais grupos, participando ativamente da vida política, social e cultural da época. No entanto, em meados do século XIX, os ideais de democracia, liberalismo, e laicização chocaram-se com os antigos ideais tradicionalistas, e os judeus

\footnotetext{
${ }^{50}$ Ilana Rabinovici Iglicky, Op. cit, p.26.

${ }^{51}$ Alan Davies. Antisemitism: An Enduring Problem in Western Society. Canadá: Jcrelations.net, 1996.
} 
começam a ser vistos como os "portadores do mundo moderno",52, como seres estranhos e semi-demoníacos. O surgimento de teorias científicas raciais no final do século XIX, gerou novas abordagens sobre a origem e a natureza humanas: todas as idiossincrasias podiam ser explicadas através da raça. Esse princípio foi assimilado pelo moderno anti-semitismo e a comunidade judaica tornou-se alvo do preconceito. Nascia ao final do século XIX, a forma moderna de anti-semitismo, fundamentada no mito do complô judaico internacional ${ }^{53}$.

Essa digressão sobre o anti-semitismo foi composta no sentido de demonstrar o avanço deste no continente europeu. Se considerarmos que a comunidade judaica brasileira proveio, principalmente, de países da Europa Oriental, Central e Ocidental convém traçar um paralelo entre a forma de organização comunitária nessas regiões e no Brasil. Para alguns autores, comunidade judaica européia formou-se sobre um histórico de segregação e de anti-semitismo no qual, a autonomia e o fechamento de suas instituições frente ao restante da sociedade constituíram a principal forma de sobrevivência de sua cultura:

"Se o anti-semitismo não se mostrasse tão arraigado, persistente e poderoso na civilização católica européia, os judeus não existiriam agora como uma comunidade distinta. Teriam sido completamente assimilados. O que vem recriando constantemente essa consciência judaica e injetando-lhe sempre, nova vitalidade, tem sido o hostil ambiente não judeu que o cerca" ${ }^{, 54}$

Ou seja, a presença do anti-semitismo e a consciência de identidade e de destino comuns teriam favorecido o desenvolvimento de laços de solidariedade entre os judeus. Ao analisarmos a amplitude alcançada pelas associações judaicas no Brasil, especificamente em São Paulo, podemos então reiterar as teses daqueles que defendem a persistência do anti-semitismo no Brasil de Vargas e Dutra. A comunidade judaicobrasileira, nesse período, era composta, basicamente, por imigrantes. Esses, em sua maioria, haviam emigrado de seus países de origem em resposta à insegurança física, à falta de dignidade, à fome e ao desemprego. Chegando ao Brasil, esses imigrantes tiveram de adaptar sua identidade original a uma nova realidade social, econômica e

\footnotetext{
${ }^{52}$.Norman Cohn. El Mito de la Conspiracion Judia Mundial. Argentina: Raices, 1969.

53 “O mito da conspiração judaica mundial representa uma adaptação moderna da tradição demonológica antiga. Segundo esse mito, existe um governo secreto judeu que, através de uma rede mundial de organismos e organizações camuflados, controla partidos políticos e governos, a imprensa e a opinião pública, os bancos e o andamento da economia."

${ }^{54}$ Isaac Deutscher. O Judeu não -judeu e outros ensaios. Rio de Janeiro: Civilização Brasileira, 1970, p. $45-6$
} 
cultural, "criando respostas diferenciadas decorrentes da relação in-group (comunidade) e out-group (sociedade brasileira), além da intervenção do mapa pessoal que cada um elabora influenciando o desenho final da "função-adaptabilidade.",55

Sob tais circunstâncias, o recomeço daqueles que imigraram foi muito difícil. Segundo Helena Lewin, os recém-chegados precisaram modificar desde seu vestuário, inadequado ao clima tropical brasileiro, até as estruturas de suas instituições comunitárias. No novo país, para que essas pudessem existir, era necessário responder a dois pré-requisitos: obedecer à legislação brasileira vigente, que prezava pela laicidade nacional e, ao mesmo tempo, limitar-se às normas e valores comportamentais judaicos, a fim de resguardar a continuidade do grupo e evitar sua assimilação. ${ }^{56}$

A primeira geração de imigrantes judeus chegados ao Brasil enfrentou vários tipos de problema, tanto em relação à sua sobrevivência e de sua família, quanto à continuidade do exercício de sua religião e valores judeus. Quanto a este último, delineavam-se duas importantes questões: o seu compromisso existencial de "ser judeu", e a necessidade emergencial de propiciar as condições necessárias para que a sua trajetória não fosse esquecida, e sua descendência pudesse se perpetuar no tempo, assim como ocorrera em seus países de origem. Nesse sentido, entendemos que o modo de organização das primeiras instituições comunitárias esteve diretamente ligado à solidariedade e ao apoio aos necessitados e aos recém chegados, integrando-os à vida do país. Nesse contexto é que avaliamos o Relief e as organizações assistenciais; as sinagogas ou os pequenos espaços de culto; e as escolas. Em período posterior, o aparato comunitário foi se tornando cada vez mais complexo, agregando novas instituições que reforçaram a identidade coletiva e individual judaicas.

"Espaços culturais e de recreação foram criados, multiplicaram-se as ofertas educacionais, de saúde e geriatria, instituíram-se atividades artísticas e intelectuais de várias modalidades, criaram-se organizações políticas de âmbito interno e de relacionamento com congêneres internacionais, além de organizações de apoio a Israel, entre outras, diferenciadas entre si por questões de natureza ideológica, religiosa ou filosófica." $" 57$

Henrique Rattner explica as peculiaridades da comunidade judaica através dos fenômenos de coesão grupal e solidariedade. $\mathrm{O}$ autor utiliza esses conceitos para tentar

\footnotetext{
55 Helena Lewin. O Desocultamento: o primeiro passo para entender a diferenciação. Rio de Janeiro, UERJ, 1993.

${ }^{56}$ Helena Lewin. Os Judeus e seu Compromisso com a Memória, Op.cit.

${ }^{57}$ Idem.
} 
entender como os membros do grupo judeu permanecem relativamente unidos, não se diluindo na sociedade mais ampla e, porque se identificam como uma unidade. Coesão significa, nesse sentido, a resistência do grupo à divisão e à assimilação de seus membros, sem que estes, no entanto, tenham consciência desse fato. Sua manutenção baseia-se na "lealdade grupal e fidelidade aos padrões tradicionais"; e na "existência de uma forte pressão externa ao grupo" ${ }^{58}$. Já a solidariedade, consiste na disposição e presteza de agir em comum, de forma consciente, resultado "tanto da participação em atividades e valores grupais, quanto da reação à discriminação e pressões externas aos membros do grupo" "59 Percebe-se a utilização, em ambas as explicações, da "pressão do meio externo" como um fator determinante no modo de condução da comunidade. Considerando-se o passado de anti-semitismo aqui descrito, acreditamos ser esse o principal catalisador das pressões externas.

A pesquisa realizada por Sílvia Zveibil a levou a concluir que "sem o gói não haveria o judeu”. Na sua opinião, a situação de contato e interação social com o meio exterior é que culmina na conscientização da condição judaica, proporcionando a autoclassificação e a classificação daqueles pertencentes ao meio externo:

"Quando as pessoas se identificam como membros de algum grupo, no caso, um grupo étnico, estão tomando posições num sistema de relações definido. No mesmo momento em que se classificam, estão classificando, por um processo de oposição, os outros grupos." ${ }^{, 60}$

No imaginário judaico a figura do goi, emerge como uma ameaça em potencial, cristalizando todo o universo discriminatório exterior. Nesse sentido, o anti-semitismo transforma-se num dos elementos de manutenção da comunidade judaica que, em busca de proteção, estabelece uma linha divisória entre o universo gói e o judaico. Segundo Elisa Caner,:

"o mecanismo de segregação do grupo encontra sua justificativa na hostilidade possível da sociedade mais ampla (...) a ameaça potencial do exterior é a garantia para a existência da segregação social enquanto mecanismo fundamental na constituição do grupo"61.

Ou seja, numa sociedade com características anti-semitas, aumentam as possibilidades de união da comunidade judaica em torno de seus membros e de suas

\footnotetext{
${ }^{58}$ Henrique Rattner, Op.cit, p. 19.

${ }^{59}$ Ibid. p. 19

${ }^{60}$ Silvia Jane Zveibil, Op.cit, p. 72.

${ }^{61}$ Ibid. p. 69.
} 
próprias instituições. Estabelece-se, desse modo, um "circulo vicioso" no qual os judeus legitimam sua realidade sectária através de seu referencial histórico e da discriminação empreendida pelo meio externo; por outro lado, percebemos que a imagem negativa do judeu persiste e se faz reformulada nos momentos em que ele se separa da sociedade mais ampla.

Elisa Caner entende que a ascensão de Hitler ao poder na Alemanha e a implantação de sua política anti-semita provocaram o retorno do segmento judaico europeu mais liberal às suas origens:

"se antes estavam desapegados da sua cultura, vivendo como cidadãos alemães, no momento em que passaram a ser vistos como 'diferentes' e, sobretudo sentiram-se 'diferentes', uniram-se e fortificaram os laços com o judaísmo" ${ }^{2}$.

A promulgação de leis anti-semitas naquele país, a partir de 1933, e a política de desnacionalização empreendida aos judeus alemães e do Leste europeu culminaram na fuga e deportação de milhares de indivíduos, que buscavam no exterior um novo paradeiro ${ }^{63}$. Diante do anti-semitismo hitlerista e da imposição de quotas à imigração judaica em países como, Estados Unidos, Canadá e Argentina, o Brasil surgia como uma possibilidade de refúgio.

Portando vistos temporários ou ingressando como católicos, milhares destes judeus ingressaram em nosso país que, desde 1930, era governado por Getúlio Vargas. Ao chegar às terras brasileiras, não contavam com nenhum apoio por parte do governo instituído. Tais fatores levaram o grupo judaico a inserir-se em ambiente brasileiro, através da recomposição de suas formas de organização de apoio mútuo existentes na Europa. Visando facilitar a inclusão da comunidade num novo ambiente e garantir o

${ }^{62}$ Elisa Caner. Judeus-alemães no Brasil - um Estudo dos Depoimentos das Vitimas do Nazismo. Dissertação de Mestrado apresentada ao Departamento de Língua Hebraica, Literatura e Cultura Judaica. FFLCH/USP, 1996, p.30.

63 O fenômeno da desnacionalização, enquanto arma da política totalitária, pode ser compreendido a partir da análise do surgimento das minorias no pós-Primeira Guerra Mundial. O final da guerra trouxe consigo a necessidade em firmar Tratados de Paz que, numa frustrada tentativa de formar Estados Nacionais, agruparam povos distintos num só Estado, cujo governo não era representativo de todos. Surgiam as minorias, uma espécie de "cidadãos de segunda classe", para os quais as leis estatais não se adequavam, sendo necessárias leis especiais, diferentes, para lidar com pessoas consideradas diferentes. Uma de suas principais conseqüências foi a produção de levas de refugiados a partir, tanto da repressão aos movimentos pela libertação nacional, quanto pela ânsia dos países europeus em se verem livres do problema provocado pelas minorias. A Segunda Guerra Mundial trouxe a resposta para a questão das minorias: desnacionalizar, expulsar, transformar os excedentes em apátridas. Rejeitados por seus estadosnação, esse grupo compreende pessoas consideradas supérfluas, sem direitos sequer a ter algum direito. Inseridos nesse grupo estão os judeus residentes na Europa Central e Oriental durante o regime hitlerista. Hannah Arendt. Origens do Totalitarismo: Anti-Semitismo, Imperialismo, Totalitarismo. São Paulo, Companhia das Letras, 1989. 
salvamento de seus conterrâneos, vítimas do regime nazista, os judeus procuraram se unir na diáspora brasileira reforçando a ação das associações beneficentes e transformando-as numa ponte entre a comunidade judaica e a sociedade exterior:

"Devemos entender a emergência e o desenvolvimento histórico das diferentes instituições comunitárias como uma resposta às necessidades de um grupo, procurando assegurar sua existência e sobrevivência num ambiente nem sempre tão aberto e acolhedor como o é a sociedade brasileira",64

Nesse contexto, consideramos que as associações não buscavam apenas assegurar a sobrevivência física de seus membros, mas sim a permanência dos judeus enquanto grupo étnico distinto, com cultura e tradição próprias. Segundo Ruben Oliven, “Embora sejam entidades abstratas, as identidades precisam ser moldadas a partir de vivências cotidianas (...)" ${ }^{65}$. As festas, os cultos religiosos, as reuniões e os debates sobre o momento vivido, concediam, pois, aos judeus refugiados no Brasil a oportunidade de voltar a se sentirem judeus e de fortalecerem seus laços comunitários.

O destino comum e o passado comum com os quais os judeus se identificam são, certamente, fatores que contribuíram para sua singular união e mútua ajuda, elementos considerados neste estudo. No entanto, não podemos relegar à um segundo plano o fenômeno do anti-semitismo que, por sua vez,força esta união enquanto reação e defesa por parte dos excluídos. Da mesma forma, o Holocausto fez reviver aos judeus, de diversas origens e nacionalidades, seu histórico de perseguição e discriminação, levando-os à união, inclusive na Diáspora.

\section{2 - Fascismo, intolerância e emigração forçada}

No Brasil, desde a década de 1920, percebemos o recrudescimento do sentimento nacionalista. A intensa imigração das décadas anteriores fora responsável por, praticamente, dobrar o número de habitantes do Brasil, principalmente nos centros urbanos, como São Paulo e Rio de Janeiro ${ }^{66}$. Geralmente melhor instruídos, os imigrantes conseguiam bons empregos e alguns até enriqueciam, enquanto um número

\footnotetext{
${ }^{64}$ Henrique Rattner, Op.cit, p. 79.

${ }^{65}$ Ruben George Oliven. "Revisitando a Tradição". in: Revista do Instituto de Filosofia e Ciências Humanas, Porto Alegre, UFRGS, v. 15, p. 31-45, 1991; In: Anita Brumer. Identidade em Mudança. Pesquisa sociológica sobre os judeus do Rio Grande do Sul. Porto Alegre: Federação Israelita do Rio Grande do Sul, 1994, p. 30.

${ }^{66}$ Segundo Jeffrey Lesser, o censo de 1920 demonstra que, nesse período, a população do país havia crescido de 17,3 milhões para 30,6 milhões de pessoas.
} 
cada vez maior de brasileiros nativos assistia à piora de sua situação social. Conflitos sociais nasceram dessa situação e foram aproveitados por políticos que perceberam o potencial de uma retórica anti-imigratória.

Nesse mesmo período, os nativistas ${ }^{67}$ agravaram os ataques aos judeus apropriando-se de teorias eugenistas importadas da Europa Central e Ocidental. Além disso, o grande número de imigrantes judeus provenientes do Leste Europeu, após a Revolução Bolchevique de 1917, acirrou o anti-semitismo manifestado por políticos e intelectuais que acusavam os judeus de serem comunistas. Em 1923, o historiador Francisco José Oliveira Vianna iniciava sua campanha a favor da arianização brasileira, enquanto Fidélis Reis, deputado federal, demonstrava sua preocupação com a aquisição de terras no Rio Grande do Sul, pela ICA - Jewish Colonization Association. ${ }^{68}$. Essas visões tornaram-se comuns a um grupo de políticos brasileiros que, após a Revolução de 1930, chegaram ao poder.

A concentração dos judeus em bairros específicos junto aos grandes centros urbanos, como por exemplo, no bairro paulistano do Bom Retiro, suscitou preocupações acerca de sua assimilação. O fato de se comunicarem em iídiche e praticarem uma religião diferente tornaram-se sinônimos de enquistamento étnico:

“(...) o que realmente separava os judeus dos demais imigrantes europeus no Brasil e os tornava objeto de minucioso exame por parte dos não judeus era sua concentração em uma série de ocupações bastante visíveis, principalmente a atividade de mascate e o comércio de tecidos (...) seu enriquecimento crescente fez aflorar o racismo e o antisemitismo latentes na sociedade que os rodeava." 69

A década de 1930, além de uma profunda mudança na estrutura política do país, marcou a consolidação dos ideais nacionalistas. O novo governo, sob o comando de Getúlio Vargas, modificou os princípios e a dinâmica da política brasileira, inclusive no que dizia respeito à imigração. O aumento do desemprego e o desejo de ascensão social num mundo menos competitivo, provocou o repúdio de alguns segmentos da população urbana contra os imigrantes, principalmente aqueles que conseguiam ser bem sucedidos. Assim, as autoridades governamentais investiram contra a imigração, principalmente

\footnotetext{
${ }^{67}$ Termo utilizado, em geral, por brasilianistas, para caracterizar o sentimento nacionalista em voga no Brasil nas décadas de 1930 e 1940.

${ }^{68}$ A Jewish Colonization Association foi fundada em 1891 pelo Barão de Hirsch, com sede em Londres e administração em Paris, reunia representantes de organizações israelitas da Alemanha, Inglaterra, Bélgica e França com o objetivo de dar assistência a emigrantes que se dirigiam as colônias agrícolas mantidas pela associação; na américa do sul estas se localizavam principalmente na Argentina e no Sul do Brasil ("Colônia Quatro Irmãos" (R.S).

${ }^{69}$ Jeffrey Lesser, Op.cit, p.67.
} 
àquela direcionada para as áreas urbanas. A partir daí, o discurso anti-imigratório passou a fazer parte do debate político e as ideologias raciais em voga na Europa, ganhariam impulso servindo de motivação para limitar a entrada de estrangeiros no Brasil.

Nesse contexto, a ideologia nacionalista saiu em defesa do branqueamento e da formação de uma população genuinamente brasileira. $\mathrm{O}$ imigrante ideal seria aquele adequado aos padrões europeus de tradição e cultura e, o discurso oficial voltou-se então contra a imigração de indivíduos fora desse padrão: "Formou-se nesse período uma verdadeira corrente em prol da 'eugenia da raça', solução que só poderia ser obtida mediante a aplicação de medidas restritivas à imigração" ${ }^{70}$. Naquele momento, a Europa não era vista sob seus limites geográficos, mas como uma "construção social que incluía concepções de cor e religião",71. Conseqüentemente, apesar de europeus, os judeus eram considerados como "indesejáveis", sendo avaliados como "etnicamente dispensáveis para a formação da população brasileira”.

O crescimento do nacionalismo, da xenofobia e a persistência de um pensamento racista entre os intelectuais brasileiros, o cenário político e econômico da Europa, naquele momento, e a influência das idéias nazi-fascistas foram os responsáveis, segundo Tucci Carneiro, pela adoção de medidas restritivas à entrada de semitas no Brasil a partir de 1937. O endosso ao discurso anti-semita no sentido de classificar a religião judaica como "raça", contribuiu para a convergência do sentimento antiimigrante com o sentimento anti-judeu. Como exemplo, citamos Oliveira Viana que acusava os judeus de serem "inassimiláveis" e "não brancos",72. Sem apoio do corpo diplomático brasileiro em missão no exterior, os judeus tornaram-se o alvo preferencial dos nacionalistas.

O governo provisório de Vargas (1930-1934) foi o responsável pela instituição das primeiras medidas restritivas à imigração judaica e japonesa e que, a partir de 1937, seriam direcionadas para conter o fluxo dos refugiados políticos, contrariando os apelos e iniciativas de um grupo de países representados na Liga das Nações. Dentre as exigências impostas pelas circulares secretas anti-semitas constavam como condições que o emigrante provasse possuir uma quantia mínima de dinheiro, na tentativa de inibir a entrada daqueles considerados pobres. Até 1937, exigia-se cartas de chamada que

\footnotetext{
${ }^{70}$ Maria Luiza Tucci Carneiro. O Anti-semitismo na Era Vargas, p. 90.

${ }^{71}$ Ibid, p. 99.

${ }^{72}$ Francisco José de Oliveira Viana. Raça e Assimilação. São Paulo: Companhia Editora Nacional, 1932.
} 
permitiam aos residentes no Brasil "chamar" seus parentes, fornecendo-lhes declarações juramentadas de apoio $^{73}$. A autorização para desembarque nos portos brasileiros ficava a encargo da Polícia Marítima, orientada pelo Ministério da Justiça e Negócios Interiores e também pelo Ministro das Relações Exteriores.

As "cartas de chamadas" transformaram-se em instrumentos de salvação utilizados pela comunidade judaica estabelecida no Brasil e que tentava salvar o maior número possível de seus conterrâneos judeus, especificamente após 1933. Não obstante, a Constituição brasileira de 1934 ao tentar coibir a imigração de indesejáveis no Brasil, acabou favorecendo a entrada de judeus refugiados, que encontravam no sistema de quotas $^{74}$ uma válvula de escape. Segundo Tucci Carneiro, valendo-se da porcentagem por nacionalidade, os judeus acabavam conseguindo vistos para ingressar no país, ainda que na categoria de temporários. Conscientes dessa abertura, o Itamaraty criou Circulares Secretas que, a partir de 1937, inibiam a concessão de vistos por parte dos diplomatas brasileiros em missão no exterior.

A Constituição de 1934, refletindo os anseios nacionalistas e xenófobos das autoridades estatais, além de estabelecer as quotas para a imigração, determinou que os empreendimentos comerciais e industriais brasileiros possuíssem uma maioria de brasileiros natos em seus conselhos administrativos, além de restringir as profissões liberais ao emprego apenas dos brasileiros nativos ou naturalizados. Sob o prisma da política externa, a entrada no Brasil dos refugiados do nazismo emergia como um problema a ser solucionado. As tentativas da Liga das Nações de transformar o Brasil num possível abrigo para esses apátridas incomodavam as autoridades brasileiras que mantinham como condições que o imigrante fosse agricultor e católico ${ }^{75}$.

Paralelamente, a suposta conexão entre judaísmo e comunismo reforçou a postura anti-semita de parte da intelectualidade e diplomacia brasileira em torno da “questão judaica”. Em 1933, Gustavo Barroso lançava a tradução do livro Os Protocolos dos Sábios de Sião que reafirmava a idéia de que "antigos judeus' estavam pretendendo dominar o mundo secretamente, possuindo para isso uma organização que se reunia, de tempos em tempos, para planejar a conquista"76. Em algumas das passagens dessa obra apócrifa, Barroso retoma preconceitos antigos, identificando os

\footnotetext{
${ }^{73}$ Jeffrey Lesser, Op.cit, p. 103.

74 Essas quotas eram anuais e permitiam a entrada no país de somente $2 \%$ do total de imigrantes provenientes da cada nação nos últimos cinqüenta anos.

75 Sobre este tema ver: Maria Luiza Tucci Carneiro. Cidadão do Mundo: Brasil e a Questão dos Refugiados Judeus (1933-1948). São Paulo: Perspectiva, no prelo.

${ }^{76}$ Maria Luiza Tucci Carneiro. O Anti-semitismo na Era Vargas, Op.cit, p.29
} 
judeus como os responsáveis pelo: “culto ao demônio, desmistificação do cristianismo, o uso da violência como principio, a hipocrisia como regra, a implantação do terror, a destruição dos valores morais e a tentativa constante de enfraquecimento do espírito crítico da população" 77 .

Finalmente, em 7 de junho de 1937, ou seja, cinco meses antes do início do Estado Novo, o governo brasileiro promulgou a Circular $\mathrm{n}^{\circ}$. 1.127, autorizada pessoalmente por Getúlio Vargas. Essa circular, a primeira de muitas outras, proibia a concessão de vistos às pessoas de "origem semítica": "fica recusado visto no passaporte a toda pessoa de que se saiba, ou por declaração própria (folha de identidade), ou qualquer outro meio de informação seguro, que é de origem semítica. " ${ }^{78}$. Caso o indivíduo declarasse professar a religião católica, era exigida a exibição da certidão de batismo. Suas cláusulas foram rigorosamente aplicadas pelos diplomatas e embaixadores brasileiros no exterior. O impacto dessa nova lei, para a comunidade judaica, deve ser avaliado sob o prisma da situação internacional: nessa época a emigração de judeus das áreas afetadas pela política nazista atingiu o seu auge, sendo raros os países que aceitavam receber levas de refugiados. Nesse contexto, associações judaicas, atuantes em diferentes localidades, tentaram driblar as restrições impostas por esses governos, utilizando-se de estratégias de salvamento: falsas certidões de batismo e suborno junto aos funcionários consulares.

Prosseguindo em sua tentativa de controlar ao máximo a imigração para o Brasil, em 1938, Vargas criou o CIC - Conselho de Imigração e Colonização, responsável por supervisionar os serviços de colonização e "preservar a constituição étnica do Brasil" "79. Além disso, promulgou o Decreto-lei 406 que, dispondo sobre a entrada de estrangeiros no território nacional, trazia no Art. $2^{\circ}$ que "ao Governo Federal reservava-se o direito de limitar ou suspender, por motivos econômicos ou sociais, a entrada de indivíduos de determinadas raças ou origens, ouvido o Conselho de Imigração e Colonização ${ }^{80 " . ~ A ~ r e s p o s t a ~ d e s s e ~ o r g a n i s m o ~ s e ~ d e u ~ n a q u e l e ~ m e s m o ~ a n o, ~}$ com a promulgação de uma nova Circular Secreta, cujo objetivo específico seria o de "regulamentar a entrada de estrangeiros de origem 'semita' em território nacional" 81 .

\footnotetext{
${ }^{77}$ Maria Luiza Tucci Carneiro. O Veneno da Serpente, Op.cit, p. 54.

${ }^{78}$ Circular Secreta $n^{\circ} 1127$ de 7 de junho de 1937. Maria Luiza Tucci Carneiro. O Veneno da Serpente, p. 115 .

${ }^{79}$ Maria Luiza Tucci Carneiro. O Anti-semitismo na Era Vargas, Op.cit, p.129.

${ }^{80}$ Decreto-lei 406 de 4/05/1938. Dispõe sobre a entrada de estrangeiros no território nacional.

${ }^{81}$ Circular Secreta $n^{\circ} 1249$, regulamentando a entrada de israelitas em território nacional. Rio de Janeiro, 27 de setembro de 1938, lata 996, maço 16177. AHI. Maria Luiza Tucci Carneiro, Op.cit, p. 132-134.
} 
Os consulados brasileiros no exterior estavam autorizados a visar, apenas temporariamente, passaportes de turistas e comerciantes, desde que seus países de origem garantissem o seu regresso; cientistas e artistas foram postos a critério da autoridade consular; e capitalistas que comprovassem a posse, e transferência para o Brasil, de uma quantia mínima em dinheiro também tinham direito a um visto.

Em 20 de agosto desse mesmo ano, foi assinado o Decreto-lei, $\mathrm{n}^{\mathrm{o}} 3010^{82}$, cujo Art.1 dispunha “(...) sobre a entrada e a permanência de estrangeiros no território nacional, sua distribuição e assimilação e o fomento do trabalho agrícola. Em sua aplicação ter-se-à em vista preservar a constituição étnica do Brasil’. Segundo Fábio Koifmann:

"A lei 3.010 é extensa, extremamente detalhada, e se assemelha a uma espécie de manual. Fornecia não somente as regras e diretrizes a serem seguidas, mas também reajustava e padronizava todos os detalhes relacionados à burocracia da entrada de estrangeiros. A lei teve por objetivo ordenar e controlar minuciosamente todo o processo de entrada e registro dos estrangeiros no Brasil, desde a autorização para a concessão do visto até a partida ou a naturalização daquelas pessoas". ${ }^{83}$

O Art. 33 desse decreto definia que o estrangeiro apátrida que desejasse vir ao Brasil, em caráter permanente ou temporário, só obteria o visto se, além dos demais documentos, apresentasse declaração oficial de que poderia regressar em qualquer época, sem impedimento algum, ao país onde tinha residido. A autoridade consular remeteria diretamente esse documento ao Registro de Estrangeiros respectivo, depois de anotar no passaporte a declaração. No entanto, para um cidadão nessas condições, necessitando abandonar seu país de origem, não era possível regressar.

Outras circulares secretas e proibitivas deram prosseguimento à política de restrições impostas pelo governo Vargas, como a Circular no 1498, que "suspendia a concessão de vistos temporários e permanentes a israelitas e seus descendentes" ${ }^{\text {, }}$; e a Circular $\mathrm{n}^{\text {o }} 1522$ de 1941, estabelecendo em um dos seus parágrafos que, "qualquer exceção quando se tratar de judeus, deve ter consulta prévia" ${ }^{\text {" }}$.

\footnotetext{
${ }^{82}$ Decreto-lei 3.010 de 20/08/1938.

${ }^{83}$ Fábio Koifman, Op. cit, p. 112.

${ }^{84}$ Circular Secreta ${ }^{\circ}{ }^{1498}$. Encaminhada por Oswaldo Aranha às Missões Diplomáticas, Consulados de Carreira e Consulados Honorários do Brasil no Exterior. Rio de Janeiro, 6 de janeiro de 1941, lata 899, maço 13858. AHI. Apud Maria Luiza Tucci Carneiro, Op.cit, p. 152.

${ }^{85}$ Circular Secreta no 1522 de 6 de maio de 1941, dá instruções para a aplicação do Decreto-Lei no 3175 , de 7 se abril de 1941. Ministério das Relações Exteriores, gestão de Oswaldo Aranha. AHI. Apud Maria Luiza Tucci Carneiro. Veneno da Serpente, p. 155.
} 
No ano seguinte, eclodiu a Segunda Guerra Mundial. Inicialmente, em 1939, após a invasão da Polônia pelas tropas alemãs, o Brasil declarou-se neutro em relação às potências mundiais. A falta de engajamento em um dos lados da guerra permitia ao governo Vargas a "simples" observação dos acontecimentos e de seus resultados, assim como a continuidade da omissão no trato aos refugiados. No entanto, a existência no Brasil de significativos núcleos alemães e italianos, engajados no movimento político de seus países de origem, levava os Estados Unidos a pressionar o país no sentido de cercear a infiltração nazi-fascista. Além disso, a luta do Brasil contra os poderes do Eixo implicaria não apenas na neutralização de células nazistas, mas também na ruptura das relações econômicas com a Alemanha.

Para o historiador Jeffrey Lesser, apesar das restrições à imigração, o ano de 1939 teria sido o momento em que mais judeus entraram legalmente no Brasil. Isso se deveria à pressão norte-americana, à permanência de Oswaldo Aranha como Ministro das Relações Exteriores, e principalmente à mudança no caráter imigratório judaico, composto, nesse momento, principalmente por judeus alemães que, segundo Oliveira Viana "eram mais semelhantes aos alemães não-judeus do que aos seus compatriotas da Palestina” ${ }^{\sharp 86}$. Não obstante, este autor desconsidera que estes refugiados tenham ingressado graças à ajuda das associações judaicas sediadas no exterior e no Brasil, e não por uma atitude humanitária do governo brasileiro.

Até 1942, Vargas utilizou-se da dubiedade para tratar das relações internacionais. Enquanto simpatizante dos paradigmas fascistas, tinha interesses em apoiar a Alemanha, postura que era duramente criticada pelos Estados Unidos que mantinham o Brasil sob constante pressão. Por outro lado, achava que os Estados Unidos demonstrariam mais interesse pelo Brasil se a posição internacional deste permanecesse obscura. Diante dessa realidade, ambos os lados se sentiam inseguros com relação à posição ideológica brasileira. Como manobra, o governo brasileiro, tomava medidas frágeis para a contenção do nazismo no país ao mesmo tempo em que discursava louvando as vitórias de Hitler. Essa situação explica o fato de o Brasil ter demorado para entrar na Segunda Guerra ao lado dos Aliados, o que somente aconteceu em 1942, quando rompeu definitivamente suas relações diplomáticas com os países do Eixo.

\footnotetext{
${ }^{86}$ Francisco José de Oliveira Viana. "Os Imigrantes Semíticos e os Mongóis e sua Caracterização Antropológica”. Revista de Imigração e Colonização, outubro de 1940. Jeffrey Lesser, Op.cit, p. 226.
} 
A partir dessa data teve início em território nacional, a "caça" aos novos inimigos militares, principalmente aos imigrantes alemães e italianos, avaliados como "nazi-fascistas" e, portanto, perigosos à segurança nacional: "Entre 1942 e 1945, a ordem social e política estava pautada na idéia de segurança nacional que julgavam ameaçada em virtude do contexto de guerra" ${ }^{, 87}$. No entanto, estas medidas de defesa funcionaram como um entrave a vivência dos judeus estabelecidos no Brasil, pois, a vigilância e a perseguição empreendidas pela Polícia Política não faziam distinção entre alemães/italianos judeus e alemães/italianos identificados com a ideologia nazi-fascista.

Segundo Priscila Perazzo, acreditava-se que todo o alemão poderia estar colaborando com a causa do Reich, e logo, representava uma ameaça social. "Com a entrada do Brasil na guerra a imagem de "indesejável" foi cada vez mais exacerbada,

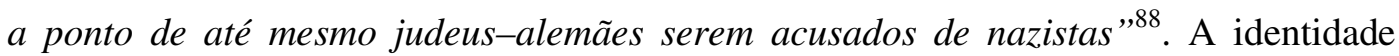
judaica foi, nesse momento, relegada a um segundo plano pelas autoridades brasileiras que, de forma generalizada, reforçaram as medidas de controle interno sobre todos os cidadãos de nacionalidade alemã e italiana, independentemente de serem judeus, e, portanto vítimas da perseguição nazista.

O ano de 1945 marcou o fim da Segunda Guerra Mundial e do governo autoritário de Vargas. Com o início do período da redemocratização elegeu-se, pelas mãos do ex-ditador, o General Dutra, em torno do qual, segundo Pedro Pomar, edificouse o mito do estadista afeito à Constituição. Em seu livro A Democracia Intolerante, o autor enfatiza que "a trajetória golpista de Dutra (1937-1945) e sua condição de 'condestável' do Estado Novo, condecorado por Hitler e Hiroito, são dissimuladas e habilmente substituídas pela imagem do governante zeloso da lei e da Constituição" 89 . Esperava-se que a ascendência de um novo regime rompesse totalmente com os preceitos do antecessor, no entanto, as medidas sintomáticas do governo de Getúlio Vargas não foram abolidas, permanecendo no governo que o sucedeu. Basta avaliarmos a legislação, a postura dos diplomatas em missão no exterior e, também, as ações da Polícia Política.

A abertura dos campos de concentração nazistas associada ao término da guerra, deixou na Europa milhares de deslocados de guerra, sobreviventes e refugiados do regime hitlerista que não pretendiam retornar aos seus países de origem. Ainda sob o

\footnotetext{
${ }^{87}$ Priscila Perazzo. Inventário DEOPS: Módulo I - Alemanha. São Paulo, Arquivo do Estado, 1997, p.78. ${ }^{88}$ Ibid. p.79.

89 Pedro Estevam da Rocha Pomar. A Democracia Intolerante. Dutra, Adhemar e a Repressão ao Partido Comunista (1946-1950). São Paulo, Coleção Teses e Monografias Vol. 4, 2002, p. 27.
} 
mandato britânico, a Palestina era incapaz de absorver a imigração judaica da Diáspora. Assim, o governo de Eurico Gaspar Dutra viu-se pressionado por um grande fluxo imigratório de judeus que, até o ano de 1949, continuaram a ter dificuldades para obter vistos para o Brasil. Tucci Carneiro apresenta em $O$ Veneno da Serpente, a imposição de circulares secretas proibitivas à imigração judaica, até o final do governo Dutra: a Instrução $\mathrm{n}^{\circ} 117 / 511.3$, de $1^{\circ}$ de fevereiro de 1947, para concessão de visto em passaportes explicitava no item b: "não visar passaportes de judeus"; em 1949, a Resolução reservada $\mathrm{n}^{\circ}$ 161, impunha "regras a concessão de visto, em caráter permanente, a um parente de semita ou alienígena de origem diversa européia. Casos análogos de outros parentes deveriam ser negados" 90 . À frente da presidência do C.I.C- Conselho de Imigração e Colonização, o diplomata Jorge Latour, cuja trajetória por Varsóvia (Polônia) e Roma (Itália) retrata o perfil anti-semita do governo brasileiro.

\section{3 - As associações judaicas e as estratégias de ajuda aos refugiados}

O início das sociedades israelitas assistenciais no Brasil coincide com a formação de uma comunidade. As primeiras associações judaicas beneficentes foram a Sociedade das Damas Israelitas (1915) e a Sociedade Beneficente Amigos dos Pobres EZRA (1916).

A Revolução Bolchevique (1917) e a Primeira Guerra Mundial (1914-1919) provocaram, naquele momento, o aumento da emigração judaica, principalmente em regiões como a Europa Oriental, Central e Oriente Médio. Desde a década de 1920, as restrições legais à imigração judaica impostas nos Estados Unidos, Canadá e Argentina, transformaram o Brasil num pólo de atração aos imigrantes judeus. Tal fluxo compunha-se principalmente de refugiados pobres e sem perspectivas de emprego e moradia no Brasil. Jacob Lestschinsky afirma, com base em números cedidos por organizações filantrópicas norte-americanas que, entre os anos de 1915/1920 cerca de 2.000 judeus imigraram para o Brasil. Esse número aumentaria expressivamente nos anos seguintes: entre 1921/1925 foram 7.139; e entre 1926/1930 a cifra chegaria a $22.296^{91}$.

\footnotetext{
${ }^{90}$ Maria Luiza Tucci Carneiro. O Veneno da Serpente, p. 122.

${ }^{91}$ Jacob Lestschinsky. Migrações Judaicas - 1840-1956; In: Henrique Rattner (org.) Nos Caminhos da Diáspora. Uma introdução ao estudo demográfico dos judeus. São Paulo, Centro Brasileiro de Estudos Judaicos, 1972, p. 77.
} 
Em junho de 1915, um grupo de senhoras paulistanas pertencentes às famílias mais antigas e prósperas do meio judaico, fundou a Sociedade Beneficente das Damas Israelitas, com o objetivo de auxiliar os novos imigrantes que chegavam ao estado de São Paulo. Por ser uma entidade feminina, uma das maiores preocupações das Damas era a assistência às mulheres parturientes que, tinham suas despesas médicas e hospitalares pagas pela Sociedade. O socorro médico promovido pelas Damas atendia não apenas aos judeus, mas também às parcelas pobres da população. Cabe ressaltar a participação de Ludwig Lorch, alemão e futuro presidente da CIP - Congregação Israelita Paulista, como um dos médicos que atendiam a associação.

No ano seguinte à fundação da Sociedade das Damas, exatamente em 20 de maio de 1916, foi fundada a Sociedade Beneficente Amigos dos Pobres EZRA, composta por judeus oriundos da Bessarábia ${ }^{92}$. Seu interesse inicial era impedir a mendicância por parte dos recém-chegados, cuidar dos doentes e arranjar emprego para os mais desamparados. Os anos de 1915 e 1916 marcaram o início da organização dos judeus em São Paulo, pois, até aquele momento, havia apenas uma sinagoga e uma pequena escola religiosa no modelo tradicional da Europa Oriental. Podemos afirmar que estas entidades, ao recepcionar de forma organizada os imigrantes e normalizar a vida deles na capital, configuraram a própria existência de uma "colônia israelita" em São Paulo, que contaria depois com a fundação de uma escola, de uma sociedade cemitério e de outras entidades.

Na década de 1920, a EZRA constituía a maior e mais importante entidade judaica, trabalhando em contato estreito com entidades estrangeiras como a HIASHebrew Immigrant Aid Society - a JCA - Jewish Colonization Association - e a JOINT - American Jewish JOINT Distribution Committe.

"A maior parte dos imigrantes chegava por meio destas organizações que providenciavam a viagem, as passagens e o contato com as organizações locais, como a EZRA e a Sociedade Beneficente do Rio de Janeiro. Estas, por sua vez, providenciavam a carta de chamada e todo o processo legal para que o imigrante pudesse entrar no país" 93

\footnotetext{
${ }^{92}$ Ver Rachel Mizrahi. Imigrantes judeus do Oriente Médio: São Paulo e Rio de Janeiro. São Paulo: Ateliê Editorial, 2003.

${ }_{93}^{93}$ Roney Cytrynowicz. Unibes 85 anos. Uma história do trabalho social da comunidade judaica em São Paulo, Op.cit.
} 
As cartas de chamada foram instituídas em 1934, pelos Decretos-lei nº $24215^{94} \mathrm{e}$ $\mathrm{n}^{\mathrm{o}} 24258^{95}$ buscando garantir que o imigrante tivesse a ocupação e os meios de subsistência afiançados por amigos ou parentes que se responsabilizavam por "chamálo" a viver no Brasil. As entidades estrangeiras assumiam a responsabilidade de estabelecer contatos entre os judeus no exterior com interesses imigratórios e, as associações brasileiras que poderiam ajudá-los. Como nem todos os interessados em emigrar possuíam estas condições, as organizações assistenciais judaicas dedicavam-se à produção das "falsas cartas", a fim de trazer para o Brasil o maior número possível de imigrantes e refugiados. Ao chegar essas pessoas eram recepcionadas no porto de Santos por integrantes da EZRA que, no momento do desembarque, intermediavam a comunicação dos recém-chegados com o Chefe da Polícia Marítima que conferia a sua documentação, validade e categoria do visto. Este ritual era necessário para que o desembarque fosse autorizado. Tensão, insegurança e medo eram sentimentos comuns a todos os refugiados que, nem sempre, portavam documentos originais ou compatíveis com a sua condição de apátridas. A EZRA responsabilizava-se também por encaminhar os imigrantes às pensões no Bom Retiro e às aulas de português, além de lhes arrumar um emprego.

Em 1924, a EZRA fundiu-se com a Sociedade Pró-Imigrante, tornando-se Sociedade Beneficente Israelita EZRA, cujos objetivos, segundo Nachman Falbel, eram:

“1) ajudar pobres necessitados; 2) fornecer ajuda médica e hospitalar a quem necessitava; 3 ) ajudar os imigrantes de passagem a chegarem ao seu destino; 4) fornecer empréstimos aos que se dirigiam à instituição; visitar enfermos em suas casas para ampará-los no que fosse necessário."

Um aspecto importante dessa associação foi o funcionamento da mesma como um pequeno banco para socorrer financeiramente aqueles que precisavam de pequenas doações ou empréstimos. Esta atitude culminou com a criação em 1928 de uma Cooperativa de Crédito, que visava entre outros, custear enterros, pagar tratamentos médicos, conceder auxílio financeiro, além de possibilitar o pagamento de passagens de parentes e amigos dos imigrantes. Desse modo, procurava-se enraizar o imigrante na sociedade brasileira, evitar o seu fracasso e, conseqüentemente, seu retorno ao lugar de

\footnotetext{
${ }^{94}$ Decreto-lei nº24215 de 9 de maio de 1934: Dispõe sobre a entrada de estrangeiros em território nacional.

${ }^{95}$ Decreto-lei no 24258 de 16 de maio de 1934: Regulamento da entrada de estrangeiros em território nacional, a que se refere o decreto n. 24.258, de 16 de maio de 1934.

${ }_{96}$ Nachman Falbel. Arquivo Histórico Judaico Brasileiro: Inventários dos Fundos das Entidades Beneficentes. São Paulo, Humanitas, 1999, p. 18.
} 
origem. As mudanças na política imigratória, após 1930, levaram a EZRA a aperfeiçoar seu campo de assessoria jurídica, importante na legalização dos imigrantes. Os judeus pobres já estabelecidos na cidade, também eram auxiliados pela entidade.

Em âmbito internacional, o ano de 1928 contou com a formação do HYCEM ${ }^{97}$, inaugurando uma nova etapa na existência da EZRA que, em conjunto com esta entidade, fundou um Comitê Central de Imigração. Esse se responsabilizou pela composição de um fundo de recursos para o custeio da imigração judaica para o Brasil. Apesar da finalidade estritamente beneficente, a EZRA não escapou da vigilância da Polícia Política varguista, atenta à entrada de judeus no Brasil. Em 1936, um comunicado reservado enviado para o Delegado Auxiliar do DEOPS/SP, tratava a associação como uma "agremiação religiosa-política israelita", demonstrando preocupação com seus planos para organizar a compra de terras, lotes e colônias, a fim de instalar novos imigrantes. Segundo o redator, tal iniciativa teria sido tomada pela agremiação para enfrentar e reduzir a atuação das autoridades, sendo que, se isso fosse conseguido, "o Brasil teria novamente 'tais elementos a farta por aí, estabelecidos com pequenas casas comerciais, dancings, belchiores, etc." 98 .

Entre 1937 e 1945, ou seja, durante todo o Estado Novo, essas associações estiveram sob a vigilância sistemática das polícias em nível federal e estadual. Em 2 de fevereiro de 1942, o Ministro da Justiça determinou ao DEOPS, que fosse exercido um controle maior das sociedades estrangeiras e nacionalizadas estabelecidas em território nacional $^{99}$. Deste modo, o Presidente da Sociedade EZRA, Benjamin Kulikovsky, naturalizado brasileiro, foi chamado a prestar declaração à Polícia Política. Informou os fins beneficentes da associação e se comprometeu a apresentar à autoridade o alvará de funcionamento expedido pelo DEIP - Departamento Estadual de Imprensa e Propaganda - o registro do serviço de Assistência Social, uma cópia do estatuto da associação e uma relação nominal com as respectivas qualificações, dos membros da diretoria. Além disso, comprometeu-se a comunicar ao DEOPS as datas de realização de todas as assembléias com antecedência de três dias, e a não efetuá-las sem a presença da autoridade ou de seu representante. Não deveria permitir a audição de estações

\footnotetext{
97 Associação criada em 1927 com o objetivo de auxiliar a emigração. Sua sede localizava-se, até 1940, em Paris.

${ }_{98}$ Comunicado Reservado no 321 para o Delegado Auxiliar de Ordem Política e Social. Departamento de Ordem Política e Social. São Paulo, 26 de novembro de 1936. Pront. $n^{o}$. 1182, Sociedade Israelita de Beneficência e Proteção aos Imigrantes “EZRA”. DEOPS/SP. APESP.

${ }^{99}$ Comunicado do Ministro da Justiça à Superintendência de Segurança Política e Social de São Paulo. Departamento de Ordem Política e Social. São Paulo, 2 de fevereiro de 1942. Pront. $n^{\circ} 1182$, Sociedade Israelita de Beneficência e Proteção aos Imigrantes “EZRA”. DEOPS/SP. APESP.
} 
emissoras do exterior no recinto e a proibiria qualquer reunião fora da sede da sociedade $^{100}$.

Desde a instauração do Estado Novo, quaisquer reuniões estavam sob suspeita e, principalmente, aquelas que estivessem relacionadas a associações de estrangeiros. Atenta ao possível caráter subversivo, a Polícia Política agia no sentido de controlar a ação das associações beneficentes judaicas que, seguindo a lógica da desconfiança, poderiam estar acobertando práticas comunistas. Daí as exigências diárias de "prestação de contas" de suas atividades e perfil dos freqüentadores. Os documentos anexados aos prontuários demonstram que os estatutos dessas associações eram minuciosamente estudados pelas autoridades policiais e sua diretoria vigiada, com o objetivo de se detectar vestígios de atitudes ou idéias subversivas. A prova deste controle, característico dos regimes autoritários, está no fato de que a maioria dos membros da Diretoria e Presidência dessas organizações foi fichada pelo DEOPS-SP ${ }^{101}$. Situação semelhante deve ter ocorrido com as organizações judaicas instaladas em outros estados brasileiros, constatação que depende da abertura dos respectivos arquivos DEOPS.

Segundo o art. $3^{\circ}$ do Decreto-lei nº383 de 1938, a realização de reuniões, festas ou assembléias dependia da aprovação da Polícia:

Art. $3^{\circ}$. E' lícito aos estrangeiros associarem-se para fins culturais, beneficentes ou de assistência, filiarem-se a clubes e quaisquer outros estabelecimentos com o mesmo objeto, bem assim reunirem-se para comemorar suas datas nacionais ou acontecimentos de significação patriótica.

$\S 2^{\circ}$. As reuniões autorizadas neste artigo não serão levadas a efeito sem prévio licenciamento e localização pelas autoridades policiais ${ }^{102}$.

O presidente da organização interessada deveria dirigir-se a um posto policial e requerer autorização para realizar o evento. Desse modo, na data e horário previstos, a Polícia destacava um pequeno grupo de* investigadores para acompanhar a reunião. Após seu término, eram produzidos relatórios detalhados, nos quais contava-se tudo o que havia sido falado e decidido, o horário de início e de término da reunião e os nomes dos oradores. Importante salientar que, em caso de conferências proferidas em outros

\footnotetext{
${ }^{100}$ Termo de Declaração de Benjamin Kulikovsky. Departamento de Ordem Política e Social. São Paulo, 2 de fevereiro de 1942. Pront. $n^{o} .1182$, Sociedade Israelita de Beneficência e Proteção aos Imigrantes “EZRA”. DEOPS/SP. APESP.

101 Pront. $n^{o} .44006$, de Guilherme Krausz; Pront. $n^{o} .38006$, de Fritz Pinkuss; Pront. $n^{o} .36002$, de Frederico Zausmer. DEOPS/SP. APESP.

${ }^{102}$ Decreto-lei $n^{\circ} 383$ de 18 de abril de 1938: Veda a estrangeiros a atividade política no Brasil e dá outras providências. Grifo nosso.
} 
idiomas como o alemão ou iídiche, destacava-se um membro da comunidade para traduzir as falas ao observador policial.

Entre o final da década de 1920 e o início dos anos 1930, outras associações judaicas foram fundadas, como a Sociedade Beneficente Linath Hatzedek (1929), a Creche Gota de Leite da B'nai B'rith (1932) e o Lar da Criança das Damas Israelitas (1939). A primeira, que depois passou a se chamar Policlínica, tratava-se de um ambulatório para consultas, procedimentos como curativos e banhos de luz, e pequenas cirurgias. Em sistema de rodízio, médicos atendiam voluntariamente na sede da entidade, em várias especialidades, e recebiam pacientes em seus consultórios, mediante desconto no valor da consulta ${ }^{103}$. Já a Gota de Leite e o Lar da Criança surgiram da necessidade de cuidar das crianças que eram órfãs, ou não tinham onde ficar enquanto seus pais trabalhavam.

A Gota de Leite, fundada por mulheres imigrantes da Alemanha, era uma entidade originada de um segmento da B'nai B'rith. Visava, especificamente, cuidar de crianças recém-nascidas, oferecendo-lhes leite e alimentos, e de suas mães, orientandoas em como cuidar dos bebês. Quanto ao Lar da Criança, tratava-se de um jardim maternal para crianças de três a sete anos, cujo trabalho ligava-se estreitamente ao realizado pelo Lar da Criança da CIP.

É interessante salientar que, apesar das diferenças existentes entre judeus de descendência ashkenazi e sefaradi, estas não prejudicaram a atuação beneficente da comunidade judaica paulistana, como podem atestar os quadros de Presidência e Diretoria das diversas associações. Por exemplo: Salo Wissman, Diretor da EZRA em 1930, foi um dos fundadores da CIP, associação de origem judaico-alemã. Estreitamente ligados à CIP, estavam também Ludwig Lorch, médico que atendia aos doentes encaminhados pela EZRA, Luiza Lorch, Alice Zrausz e Ammy Zausmer, sendo as duas últimas de nacionalidade alemã e fundadoras da Gota de Leite. Em 1940, a Gota de leite uniu-se com o Lar da Criança e com a Sociedade das Damas Israelitas, ambas de origem sefardi, para fundar a OFIDAS. Percebemos, pois, que a solidariedade considerava apenas o desamparo dos necessitados e não suas comunidades de origem.

Ainda em 1936, foi fundado em São José dos Campos o Sanatório EZRA para tuberculosos que, nos anos 1940, chegou a ter 120 leitos e 30 funcionários. Imigrantes doentes, de qualquer credo ou nacionalidade, tinham a oportunidade de se recuperar no

\footnotetext{
${ }^{103}$ Roney Cytrynowicz. Unibes 85 anos, Op.cit.
} 
Sanatório, cujo sucesso mobilizou várias campanhas de arrecadação de recursos para manter os pacientes e para a continuidade das atividades da instituição. Até a década de 1940, a tuberculose era uma das doenças com maior índice de mortalidade no mundo e considerada incurável; o tratamento existente era uma combinação de internação em localidades consideradas "zonas climatéricas", com descansos, dietas e uma rígida disciplina de comportamento. O Sanatório funcionou até 1966, quando, diante da queda brusca no número de internos e da desapropriação do terreno pela prefeitura local, suas atividades foram encerradas ${ }^{104}$.

Organizada, a comunidade judaica paulistana foi capaz de preencher o vácuo deixado pelo governo de Getúlio Vargas no que dizia respeito à recepção e amparo aos imigrantes recém-chegados. Não obstante, a legislação coercitiva e os preceitos antisemitas persistentes no Brasil, dificultaram o andamento dos trabalhos dessas associações que se desdobravam entre o auxílio aos refugiados e as explicações à Polícia Política. Medo e tensão persistiram nos anos de 1930 e 1940, quando Getúlio Vargas não escondia suas simpatias pelos regimes nazi-fascistas. A presença do Partido Nazista em São Paulo, fundado em 1932, da mesma forma que o avanço dos integralistas pelo país, manteve a comunidade judaica acuada, fechada entre os seus iguais. $^{105}$

\footnotetext{
${ }^{104}$ Roney Cytrynowicz. Unibes 85 anos, Op.cit.

${ }^{105}$ Sobre as organizações de direita atuantes no Brasil, muitas das quais inspiradas nos paradigmas do fascismo europeu, ver: Ana Maria Dietrich. Caça às suásticas : o Partido Nazista em São Paulo sob a mira da Polícia Política. São Paulo: Humanitas/ FAPESP/ Imprensa Oficial, 2007; João Ricardo de Castro Caldeira. Integralismo e política regional: a ação integralista no Maranhão (1933-1937). São Paulo: Annablume, 1999.
} 


\section{II - FRENTES DE RESISTÊNCIA AO NAZI-FASCISMO}

\section{1 - Congregação Israelita Paulista: Ação e Solidariedade}

A comunidade judaica brasileira encontrava-se organizada desde o início do século XX. A Primeira Guerra Mundial provocara um aumento considerável desta imigração para o Brasil e também para outros países como a Argentina e os Estados Unidos. A imposição de quotas imigratórias por percentagem de nacionalidade obrigou a comunidade, já estabelecida, a se organizar em prol da recepção dos novos imigrantes e, a partir de 1933, dos refugiados do nazismo. Entre as décadas de 1910-1920, algumas das famílias judias mais tradicionais e bem estabilizadas fundaram sociedades beneficentes, cujo ônus recaía sobre os próprios sócios ou era conseguido em campanhas beneficentes envolvendo a comunidade. Importante salientar que, nesse período, os imigrantes judeus eram provenientes em sua maioria, dos países do Leste europeu, falavam o iídiche e dedicavam-se ao comércio.

Foi grande o número de associações judaicas com fins assistenciais, políticas, culturais e esportivas fundadas em São Paulo entre 1920 e 1950. Assim, no que tange ao assistencialismo e à recepção aos refugiados, a associação de maior projeção nas décadas de 1930 a 1950 era a Congregação Israelita Paulista, razão que nos serviu de critério para a seleção da documentação junto ao A.H.J.B.

A ascensão nacional-socialista na Alemanha em 1933 e a eclosão da Segunda Guerra Mundial em 1938 modificaram o fluxo imigratório judaico para o Brasil. Aos judeus provenientes do Leste europeu somaram-se outras nacionalidades à medida que o exército alemão promovia, em cadeia, a ocupação da Tchecoslováquia, Áustria e Polônia. Em sua maioria eram judeus alemães, educados nos padrões europeus, muitas vezes com formação universitária e pertencentes às classes-média e média-alta. Esse contingente, apesar de judeu, não se identificava com a corrente imigratória anterior que emigrou para o Brasil, proveniente do Leste-europeu ${ }^{106}$. Enquanto estes viam na imigração um modo de escapar da pobreza e dos pogroms, os judeus-alemães a viam como o desmoronar de sua existência, como o fim do mundo que conheciam. Até a ascensão do nazismo, as famílias judaicas residentes da Alemanha encontravam-se

\footnotetext{
${ }^{106}$ Estes foram direcionados, em grande parte, para as colônias da ICA, no sul do Brasil. Muitos não eram alfabetizados e provinham das antigas aldeias da Bielorússia. Um outro segmento, representante da classe média européia, optou pelos grandes centros urbanos brasileiros, como São Paulo, Porto Alegre e Recife.
} 
plenamente integradas à vida social, cultural, política e econômica alemã, apesar das manifestações anti-semitas cujas raízes remontam ao final do século XIX. Na maioria das vezes, os judeus sentiam-se mais alemães do que os alemães ditos "arianos". A emigração, por ser forçada, surgia assim, como uma ruptura que, apesar de salvar vidas, lhes causava uma profunda sensação de perda, deslocamento e desagregação familiar.

Desde a década de 1920, a pequena comunidade asknasi paulistana se preocupava com a formação de uma instituição que se prestasse a atendê-los, principalmente com relação aos assuntos religiosos. Com este objetivo, em 1924, existia em São Paulo a Congregação Israelita Asknazi, composta pelas famílias Lorch, Klabin e Lafer, as mesmas que estariam envolvidas com a formação da CIP. A principal preocupação da Congregação Asknazi, naquele momento de relativa calmaria, recaia sobre a construção de uma sinagoga e de um ginásio ${ }^{107}$.

A partir de 1933, com a chegada dos primeiros 150 imigrantes judeus da Alemanha a São Paulo, um segmento deste grupo fundou a CARIA - Comissão de Assistência aos Refugiados Israelitas da Alemanha. A fundação de uma associação dedicada aos refugiados é sintomática da difícil realidade que começava a ser vivenciada pelos judeus na Alemanha. Sustentada através de donativos e mensalidades angariados junto aos diversos grupos da comunidade israelita paulistana, a CARIA prosseguiu com suas atividades até o final de 1936. Seus objetivos residiam em oferecer aconselhamento, assistência médica e ajuda financeira aos recém-chegados. Esta última consistia na manutenção do recém-chegado por períodos curtos, de um a dois meses, até que o mesmo conseguisse um emprego. Eram concedidos também pequenos empréstimos, usados para financiar cartas de chamada, ou para fins econômicos, como o requerimento de licenças:

"Quando avisada pela HIAS, a CARIA recepcionava os imigrantes no navio,
desembarcava e despachava sua bagagem e os encaminhava a uma pensão,
responsabilizava-se pelas despesas de manutenção dos que fossem carentes de recursos
até que tivessem condições de auto-sustentação. Nas ocasiões em que foi necessário,
forneceu-lhes roupa de trabalho, ferramentas e encarregou-se de regularizar seus
documentos. Organizou também aulas de português. A principal preocupação, sempre,
era dar condiç̃̃es ao imigrante de realizar com dignidade a sua independência
econômica."

107 Carta da Família Klabin para a Diretoria da Congregação Israelita Askenasi. São Paulo, 26 de dezembro de 1924. Fundo Lorch/LEER - USP.

${ }^{108}$ Alice Irene Hirschberg. Desafio e Resposta, a História da Congregação Israelita Paulista, Op.cit, p. 35 . 
No ano seguinte, em 1934, um grupo de 42 jovens que haviam sido recebidos pela CARIA, apoiados por um grupo de alemães judeus, decidiram fundar a SIP, Sociedade Israelita Paulista. Seus objetivos residiam no aspecto cultural e religioso da coletividade, visando conscientizar os jovens e torná-los orgulhosos de seu judaísmo; propiciar aos seus sócios um melhor conhecimento de São Paulo e do Brasil; e unificar todas as judaicas, de diferentes origens. Nesse sentido, eram ministradas aulas de hebraico, religião e história judaicas, além de promoverem encontros incentivando práticas esportivas e a comemoração das grandes festas judaicas.

O auxílio oferecido pela CARIA mostrou-se suficiente até o ano de 1935, momento no qual o número de imigrantes ainda não era alto, e sua situação econômica e jurídica, do ponto de vista de sua permanência no país, não exigiam grandes despesas. No entanto, a partir de 1936, o perfil dos imigrantes seria drasticamente alterado: eram mais velhos, mais numerosos e, geralmente, portavam vistos temporários. Surgiam então, novas necessidades financeiras, no sentido de evitar a situação de ilegalidade e o emprego em "profissões indesejáveis",109.

Angariar novos fundos entre a comunidade judaica já radicada em São Paulo, não era possível naquele momento e, as negociações com a ICA a respeito desse financiamento não resultaram em nenhum acerto. Ludwig Lorch, nesse mesmo ano, viajou aos Estados Unidos a fim de fechar um acordo com o American Jewish JOINT Distribution Committee. Detalhando a situação e as necessidades dos refugiados em São Paulo, Lorch conseguiu os recursos necessários para iniciar as atividades do Departamento de Assistência Social da futura Congregação Israelita Paulista ${ }^{110}$.

Em outubro de 1936, uma reunião na residência de Ludwig Lorch deu origem ao "Protocolo de Fundação de uma Congregação Israelita". Desse modo, em $1^{\circ}$ de julho de 1937, um grupo de judeus alemães, entre os quais se encontravam o próprio Dr. Lorch, Hans Hamburger, Salo Wissmann, Frederico Zausmer, Guilherme Krauz e o rabino Fritz Pinkuss inauguraram a primeira sede da CIP - Congregação Israelita Paulista ${ }^{111}$. Enquanto líderes comunitários pensavam no futuro de uma coletividade judaicobrasileira, através da criação de uma comunidade capaz de adaptar o judaísmo às

\footnotetext{
109 Relatório sobre as atividades do Departamento de Assistência Social. s/d. Fundo Ludwig Lorch, LEER-USP.

${ }^{110}$ Roney Cytrynowicz. Unibes 85 anos. Uma história do trabalho social da comunidade judaica em São Paulo Op.cit.

${ }^{111}$ No período a que tange o nosso estudo, a sede da CIP situava-se Rua Brigadeiro Galvão, $\mathrm{n}^{\circ}$ 181, em São Paulo, Capital.
} 
condições brasileiras e não apenas com a proposta de receber refugiados ${ }^{112}$. Dentre seus objetivos constavam iniciativas para garantir o salvamento e a recepção aos refugiados do nazismo.

O ensino da língua portuguesa foi introduzido em meio à Congregação, enquanto às sextas-feiras, eram realizados cultos regulares. Segundo o rabino da Congregação, Fritz Pinkuss: “Os que na semana anterior tinham chegado como 'refugiados', na próxima iam deixando de sê-lo, pois efetivamente, a cada sexta-feira se encontravam amparados" $" 113$.

Seus estatutos, aprovados em 18 de dezembro de 1938, caracterizavam a Congregação como uma comunidade religiosa brasileira que, excluindo quaisquer fins políticos, propunha-se a cultivar os valores da religião judaica e fomentar a coordenação cívica dos israelitas residentes no Brasil. Constituíam suas aspirações especiais:

“a) Organizar e manter os serviços religiosos e cultivar os ritos israelitas,

b) Ministrar o ensino religioso israelita,

c) reunir a juventude israelita em torno dos ideais brasileiros e dos da religião israelita;

d) Fomentar a cultura israelita e a educação cívica brasileira entre os adultos, por meio de conferências periódicas, cursos regulares e a instalação de uma biblioteca,

e) Organizar e manter os serviços religiosos em caso de luto (chevraus) e aniversários de falecimento (minjan);

f) Organizar e manter um serviço de beneficência;

g) Cuidar da educação física e cultivar a vida social.",114

Contrapondo-se à realidade ditatorial da política brasileira durante os anos de 1930-40, os estatutos originais da Congregação, assim como os das demais associações israelitas paulistas, ofereciam aos associados uma convivência inserta em preceitos democráticos. Todos os sócios em dia com as suas obrigações na CIP, inclusive as sócias, compunham a Assembléia Geral da Congregação, responsável por eleger, através do voto, a Assembléia dos Representantes. Esta era composta por vinte e cinco membros com mandatos de três anos e, constituía, juntamente com o Presidente, o poder máximo no interior da Associação. Importante ressaltar que as votações ocorriam mesmo quando não havia oposição aos candidatos ${ }^{115}$.

\footnotetext{
${ }^{112}$ Fritz Pinkuss. Estudar, Ensinar, Ajudar. Seis Décadas de um Rabino em Dois Continentes. São Paulo Livraria Cultura Editora, 1989.

${ }^{113}$ Ibid. p.52

${ }^{114}$ Art. $2^{\circ}$ dos Estatutos da Congregação Israelita Paulista. São Paulo, 18 de dezembro de 1938. Pront. 4705, da Congregação Israelita Paulista. DEOPS/SP. APESP.

${ }^{115}$ Ata da Ata da reunião da Assembléia dos Representantes da CIP. São Paulo, 6 de setembro de 1939. Fundo 187/AHJB.
} 
São Paulo, 12 de Dezembro de 1944

Aos Sócios da C. I. P.

\section{POR QUE VOTAR NA \\ "CHAPA RECOMENDADA?"}

$P \bigcirc R Q U E$ oC. I. P. que até agora tem desempenhado uma taréla benemérita, deve continuar.

$P O R Q U E$ os nomes desta chapa representam a Garantia da Continuação da C. I. P.

PORQUE

e, portanto, de todas as suas indispensaveis instituiçōes.

parada a amparar as vítimas da guerra e do nazi-facismo, onde quer que se encontrem.

PORQUE a C.I. P. deve abrigar num ambiente de cordialidade israelitas das mais diver-

PORQUE sas procedencias e opiniōes individuois.

a C. I. P. considera o seu dever sagrado manter e serantir a plena autonomia dos ritos ortodoxos e liberais na maior harmonia.

PORQUE

a C. I. P. deve continuar a publicação da "Crônica Israeliia" para a qual deverá ser adoptada uma orientação definida afim de que seja ela uma tribuna imparcial para os legitimos interesses de toda a coletividade israelita.

PORQUE

a C. I. P. não deve, nem pode ser entregue a grupos ou fraçōes que, atrós de um "programa" - "manifesto" nebulosos e agressivos, escondem fins bem diferentes que levariam a comunidade à discordia e à dissolução.

Contra o "manifeste" da chapa "Pró Reforma" tem-se claramente pronunciado os senhores Mauricio Grinberg, Horacio Lafer, Jacob A. Lafer e José E. Mindlin, membros da Diretoria da C. I. P.

Sinceramente pedimos que ajudeis a proteger a C. I. P. cantra experiências arriscadas e a garantir a C. I. P., para um futuro de grandes tarefas e responsabilidades:

Defendei, pois, a obra edificada om oito anos de duros esforços $\theta$ sacrificios feita por vós a para vós, votando na chapa que traz o cabecalho

\section{CHAPA RECOMENDADA}

\section{PELA DIRETORIA E ASSEMBLÉIA DOS REPRESENTANTES}

Siegiried ADLER - Kurt ARNHOLD - Frederico BRAHMS - Heinz BRANDT - Walter CALLMANN - Cecilia COHN SEIDEMANN - Walter ELSBACH - Hugo FRANK - Friedrich GOTTDENKER - Martin GRUMACH - Guenter HEILBORN - Alberto HOFMANN - Artur HURTIG - Ernst JOSEPHS - Otto JUNGMANN - Carlos KATZENSTEIN lsidorKIERSKI - Ernst KOCH - Guilherme P. KRAUSZ - Carlos Alberto LEVI - Mario Eli LEVI - Luiz LORCH - Feodor Meyer - Georg MOSLER - Kurt MUNTER - Erwin OELSNER - Gerhard ORGLER Siegbert PEISER - Hans Julius PEYSER - Alfred RECTOR - Ernst REICHENBACH - Henrique REICHMANN - Erich ROSENTHAL Martin RUBEN - Ernst SCHEYE - Kurt SIEBNER - Heinz SILBERBERG - Oscar SINGER - Richard SONNENTHAL - Alberto STAHL Hans STEINBERG.

As esposas dos nossos sócios podem e, porisso, devem votar. Cada eleitor tem o direito de riscar nomes de pessôas que não aprova. A Chapa finalmente depositada na urna, não precisa conter 60 nomes,

- Propaganda das chapas formadas para concorrer à Assembléia dos Representantes e Direção da Congregação Israelita Paulista nas eleições de 1944. Departamento de Ordem Política e Social. Pront. $n^{\circ} 4705$, da Congregação Israelita Paulista. DEOPS/SP. APESP. 


\section{MANIFESTO AOS SOCIOS \\ da Congregação Israelita Paulista}

Aos Sócios da C. I. P.,

São Paulo, Dezembro de 1944.

Considerando ser o Judaismo um todo indivisível, composto de elementos morais, éticos, religiosos, históricos - legado comum de todos sos seus filhos, venham de onde vierem - e conscientes do fato de constituirem êsses elementos para cada Judeu a base da sua existência espiritual e moral:

Considerando, também, que a C. I. P., composta principalmente de refugiados e estrangeiros, deve procurar se aproximar dos Judeus radicados desde muito tempo entre o bondoso Povo brasileiro;

\section{QUEREMOS:}

Que a Administração da C. I. P., dedicando todos os seus recursos para o fim fundamental da conservação da Comunidade judáica,

Colabore com tôdas as Organizações judáicas locais, nos campos das atividades até agora desenvolvidas pela C. I. P.;

mundo;

Apoie com sentido unitário tôdas as iniciativas tendentes a eliminar a miséria judáica no

Coopere na formação de uma federação de tôdas as Associações Israelitas em São Paulo e apoie todos os esforços empregados nêsse sentido;

\section{ALÉM DISSO PRETENDEMOS:}

1. Escolher para os lugares diretivos só quem tiver provado estar na posse de condições morais que dêle façam verdadeiramente um expoente judeu;

2. Alterar os Estatutos da C. I. P. de molde a só terem assento e voz ativa nos grêmios com direito a voto, aquêles que para tal foram expressamente designados pela Assembléia Geral, e a não ser lícito às pessoas remuneradas pela C. I. P. pertencerem a tais grêmios representativos:

3. Estabelecer um regulamento eleitoral que permita, futuramente, eleições livres de qualquer ingerência da Administração anterior:

4. Simplificar quanto possível o sistema adiministrativo da C. I. P.;

5. Favorecer as manifestações ativas da vida judáica dentro da Congregação, afim de conceder aos Sócios ortodoxos oportunidade para viverem da acôrdo com os preceitos rigorosos da Religião:

6. Melhorar o ensino israelita no âmbito de atividades da Congregação, dentro do espírito da tradição judáica, com medidas tendentes à maior divulgação e aprof́undamento dos conhecimentos judáicos no meio da juventude israelita em idade post-escolar;

7. Tomar medidas adequadas para que a redação da "Crônica Israelita" cesse tôda propaganda, aberta ou disfarçada, contrária aos séntimentos e aos interêsses judáicos, noticiando e comentando, viceversa, de maneira objetiva e condigna, tôdas as ocorrências israelitas, tomando em conta tôdas as tendências existentes dentro da Comunidade, e abstendo-se de tudo que puder provocar discórdia;

8. Continuar e manter tôdas as instituições criadas pela C. I. P., tanto quanto o permitam os recursos financeiros, coordenando a Assistência Social da C. I. P. com as demais Organizações similares, afim de conseguir o máximo rendimento possível.

Quem estiver de acôrdo com êsłe programa, dê o seu voto à nossa lista, com a senha

"CHAPA PRO REFORMA DA C. I. P."

SALO WISSMANN - ADALBERTO CORINALDI - GEZA KLINGER - ROBERTO SALOMON

N. B. - As espôsas dos Sócios trambém têm direito a voto. Providenciem, pois, para que as suas espôsas compareçam à eleição.

A VOTAÇÃo TERÁ COMEÇO Às 20 HORAS INDEPENDENDO DE QUALQUER DISCUSSÃO!

Distribuição interna autorizada pelo D. E.I. P.

- Propaganda das chapas formadas para concorrer à Assembléia dos Representantes e Direção da Congregação Israelita Paulista nas eleições de 1944. Departamento de Ordem Política e Social. Pront. $n^{\circ} 4705$, da Congregação Israelita Paulista. DEOPS/SP. APESP. 
A administração da CIP ficava a cargo da Diretoria: onze indivíduos eleitos pela própria Assembléia dos Representantes, com mandatos de três anos. Cada um dos membros da Diretoria encabeçava uma das diferentes Comissões da CIP, compostas por cinco membros e responsáveis por tomar as decisões cotidianas na Associação. O rabinato da Congregação cabia àquele que fosse escolhido pela Assembléia dos Representantes, sendo Fritz Pinkuss o primeiro a ocupar esse cargo, cuja presença esteve ligada à Congregação até a sua morte.

Apesar de intitular-se uma associação beneficente com finalidade estritamente cultural e religiosa, a CIP enfrentou, em seus primeiros anos, problemas relacionados à legalização de seu alvará de funcionamento. Em outubro de 1937, o agente do DEOPS Venâncio Ayres, em opinião acerca do registro dos estatutos da CIP, concluiu que podia-se inferir que tal associação não tinha apenas fins religiosos, mas pretendia, principalmente que "não se deixasse apagar o fogo sagrado e racial dos judeus",116. Venâncio expôs que era suspeita a honestidade de uma associação que exigia para o sócio uma idoneidade assegurada por dois outros sócios, já que, se a associação fosse apenas religiosa, teria como dever "conclamar ovelhas ao paraíso". Desse modo, as "desgarradas, más e de identidade duvidosa" é que deveriam ser chamadas à Associação. Diante do exposto, Venâncio Ayres indeferiu o requerimento de funcionamento da CIP. ${ }^{117}$

Importante salientar que as entidades judaicas assistenciais possuíam em seus estatutos a exigência de boa conduta para os sócios porque estes deveriam estar aptos a contribuir mensalmente com uma quantia para a manutenção da associação, capacitados a acolher e lidar com os imigrantes recém-chegados, além de isentos de qualquer suspeita policial. Deparamo-nos aqui, com o caráter preventivo da Polícia Política varguista que coibia os atos de solidariedade de certos segmentos da população que, segundo a lógica policial, poderiam estar acobertando interesses e ações políticas de cunho subversivo. Devemos acrescentar que não interessava ao governo a organização sistemática das comunidades imigrantes que, assim, fortaleciam suas identidades culturais e nacionais. Daí o investimento do Estado em incentivar a assimilação e insistir no combate às diferenças, elementos persistentes na propaganda oficial.

\footnotetext{
${ }^{116}$ Cópia de Informe de Venâncio Ayres para o Superintendente de Ordem Política e Social em 20 de outubro de 1937. São Paulo, 14 de janeiro de 1938. Pront. $n^{\circ} 4705$, da Congregação Israelita Paulista. DEOPS/SP. APESP.

${ }^{117}$ Idem.
} 
Não apenas as associações estavam sob a mira da vigilância policial. Grande parte dos cidadãos envolvidos com a fundação da CIP e em sua coordenação foram prontuariados no DEOPS-SP. Fritz Pinkuss, Salo Wissman, Frederico Zausmer, Guilherme Krausz, Alfred Ettlinger, Charlotte Hamburger, Alfred Hirschberg e Luiza Lorch, são alguns dos nomes que figuraram no arquivo da Polícia Política nas décadas de 1930 e $1940^{118}$. Em sua maioria, seus prontuários são compostos por termos de declarações, pedidos de salvo-condutos e atestados de boa conduta, necessários à locomoção de qualquer imigrante no território nacional.

O problema da concessão do alvará arrastar-se-ia por mais algum tempo e, em dezembro de 1937, a CIP requereu esclarecimentos do Secretário de Segurança Pública, acerca do motivo para tal impedimento. Em janeiro de 1938, o Delegado de Ordem Social, justificou que os motivos eram de caráter reservado, relacionando-se com "a defesa dos altos interesses sociais na Nação" ${ }^{\text {"19 }}$. Naquele mesmo ano, o ato policial seria reforçado pelo Decreto-lei $\mathrm{n}^{\circ}$. 383, que vedava aos estrangeiros fixados em território nacional e, aos que se encontravam no Brasil em caráter temporário, o desenvolvimento de qualquer atividade de natureza política e o envolvimento direto ou indireto, nos negócios públicos do país:

“Art. $2^{\circ}$. E'-lhes vedado especialmente:

1 - Organizar, criar ou manter sociedades, fundações, companhias, clubes e quaisquer estabelecimentos de caráter político;

Art. $3^{\circ}$. E' lícito aos estrangeiros associarem-se para fins culturais, beneficentes ou de assistência, filiarem-se a clubes e quaisquer outros estabelecimentos com o mesmo objeto, bem assim reunirem-se para comemorar suas datas nacionais ou acontecimentos de significação patriótica.

$\S 1^{\circ}$. Não poderão tais entidades receber, a qualquer título, sub-venções, contribuições ou auxílios de governos estrangeiros, ou de entidades ou pessoas domiciliadas no exterior.

(...) Art. $6^{\circ}$. As entidades referidas nos arts. $3^{\circ}$ e $4^{\circ}$ não poderão funcionar sem licença especial e registro concedido pelo Ministério da Justiça e Negócios Interiores (...)". ${ }^{120}$

Por outro lado, a Congregação preferia sempre não se imiscuir em assuntos que tivessem qualquer tipo de fundo político, pois, estava ciente da legislação brasileira e as ações da Polícia Política nesse sentido. Em 1943, diante de um convite do Movimento

\footnotetext{
118 Pront. $n^{o}$ 38006, de Fritz Pinkuss,; Pront. $n^{o}$.69353, de Salo Wissman,; Pront. $n^{o} .36002$, de Frederico Zausmer,; Pront. $n^{\circ} 44006$, de Guilherme Krausz,; Pront. $n^{\circ} 45885$, de Alfred Ettlinger,; Pront. $n^{o} 74897$, de Charlotte Hamburger,; Pront. $n^{o} 23074$, de Alfred Hirschberg,; Pront. $n^{o} .59120$, de Luiza Klabin Lorch,. DEOPS/SP. APESP.

${ }^{119}$ Requerimento da Congregação Israelita Paulista para o Secretário de Segurança Pública. São Paulo, 20 de dezembro de 1937. Pront. $n^{o}$. 4705, da Congregação Israelita Paulista. DEOPS/SP. APESP.

${ }^{120}$ Decreto-lei $n^{o} .383$ de 18/04/1938. Veda aos estrangeiros a atividade política no Brasil e dá outras providências.
} 
dos Alemães Livres do Brasil para participar de um protesto contra o décimo aniversário do regime nazista, a resposta de Ernst Koch, em nome da CIP, mostrou-se pesarosamente negativa:

"Reafirmar, em nossa correspondência, a importância vital da luta contra o hitlerismo, parece-nos desnecessário, pois que não há judeu que não compreenda o que o hitlerismo significa para a civilização humana e a vida religiosa. (...) Sendo, porém, a Congregação Israelita Paulista uma associação brasileira de fins religiosos e beneficentes, é evidente que ela não pode entrar em negociações sobre um "plano de ação conjunta" com uma associação estrangeira composta de alemães e cujo objetivo é não somente o de manifestar a oposição de seus sócios alemães contra a política hitlerista da Alemanha $(\ldots), 121$

A CIP declarou ainda que não faria qualquer tipo de propaganda contrária à ação do Movimento Livre, acreditando até, que muitos dos seus membros participariam do dito protesto. No entanto, após tantos problemas relacionados ao alvará de funcionamento e à substituição da sua diretoria por brasileiros natos, a Congregação não poderia arriscar sua posição na sociedade brasileira para participar de uma manifestação pública em repúdio a um sistema político. Ainda mais, sendo aquela organização presidida e composta por alemães, o que contrariava as imposições ditadas pelo Decreto-lei 383. Mesmo assim, considero importante ressaltar o papel deste Movimento e de seus membros enquanto grupo organizado de resistência aos regimes nazi-fascistas. Muito pouco se conhece e quase nada se escreveu sobre estas frentes que, em diferentes instancias, se fizeram presentes na sociedade brasileira. Dentre seus integrantes, os judeus certamente tiveram uma marcante atuação, muitas vezes na clandestinidade.

Durante todo o ano de 1943, o Movimento dos Alemães Livres esteve na mira da vigilância policial. Composto por alemães apátridas, a organização lutava pela libertação da Alemanha, pela deposição de Hitler e de seu regime nazista e pelo fim do anti-semitismo. No entanto, para a Polícia paulistana parecia inadmissível um Movimento comandado por alemães clamar por liberdade, já que a Alemanha não havia sido invadida por nenhum outro país. Assim, o Movimento fora classificado, em fevereiro daquele ano, como um mero pretexto, uma artimanha dos súditos hitleristas para angariar simpatias entre o povo brasileiro e, assim, disseminar sua ideologia

\footnotetext{
${ }^{121}$ Cópia da resposta de E. Koch, Presidente da Assembléia dos Representantes da Congregação Israelita Paulista, à carta de 13 de janeiro de 1943 do Movimento dos Alemães Livres do Brasil. São Paulo, s/d. Fundo Lorch/LEER - USP.
} 
nazista. Ao final de 1943, o Movimento dos Alemães Livres informava à Polícia sobre a sua dissolução. ${ }^{122}$

Nesse momento, um dos problemas da CIP frente à Polícia Política, era o auxílio financeiro enviado pela JOINT - American Jewish JOINT Distribution Committee recebido de modo regular até 1942 . Este ato infringia a primeira disposição do art. $3^{\circ}$ Decreto-lei $\mathrm{n}^{\circ}$. 383, motivo que levou a CIP a procurar o aconselhamento da UNIÃO Associação Beneficente Israelita do Rio de Janeiro ${ }^{123}$ que, por localizar-se no Distrito Federal, estava mais próxima da cúpula política brasileira. Sendo assim, no início de agosto de 1939, a associação carioca enviou à CIP o parecer de Pedro Baptista Martins $^{124}$ que, analisando o texto da lei, concluiu que esses preceitos legais transformavam em criminosos aqueles que a infringissem, liberando de quaisquer ônus, porém, instituições brasileiras, formadas por brasileiros ${ }^{125}$.

No final daquele mesmo mês de agosto, em sessão conjunta extraordinária, a Assembléia dos Representantes da CIP decidiu eleger novos membros para a Diretoria, confirmando o fato de que “(...) a Diretoria deve ser composta na sua maioria de membros brasileiros (...) por razões de decretos de autoridades (...)"126. Os membros antigos, estrangeiros em sua maioria, pediram demissão de seus cargos e, a partir daquele momento, novos diretores foram indicados de modo à prevalência da identidade brasileira.

A associação da CIP às atividades políticas e a intransigência governamental no quesito "alvará" foram questionados por Ludwig Lorch ainda em maio de 1938, durante a sessão da Diretoria. Lorch alegava ao alegar desconhecer os motivos pelos quais o assunto "alvará" ainda pendia, já que, conforme publicação no Diário Oficial, "sociedades religiosas nem precisam de alvará". ${ }^{127}$ A resposta viria no ano seguinte, após uma nova solicitação de licença para funcionamento, quando a Polícia exigiu, através de comunicação pelo Diário Oficial, a modificação do art. 27 dos estatutos da CIP: "Em caso de dissolução da Congregação, todos os seus bens serão entregues a

${ }^{122}$ Pront. $n^{o}$. 53569, do Movimento dos Alemães Livres. DEOPS/SP. APESP.

123 A União - Associação Beneficente Israelita foi fundada em agosto de 1936, e tinha por finalidade prestar ajuda aos imigrantes de todas as maneiras - com informação e orientação, recursos financeiros, ensino do português, busca de emprego, entre outros.

${ }^{124} \mathrm{O}$ documento não esclarece sua posição social ou profissão.

125 Parecer de Pedro Baptista Martins à União (Associação Beneficente Israelita). São Paulo, 4 de agosto de 1939. Fundo Lorch/LEER - USP.

126 Ata da Sessão dos Representantes em conjunto com a Diretoria. São Paulo, 20 de agosto de 1939. Fundo 187/AHJB.

127 Protocolo da Sessão da Diretoria da Congregação Israelita Paulista. São Paulo, 12 de maio de 1938. Fundo 187/AHJB. 
uma instituição israelita de São Paulo..." ${ }^{128}$. Modificado o estatuto, a Congregação destinaria seus bens, em caso de dissolução "à instituição nacional"129. A exigência foi prontamente atendida e a cópia dos novos estatutos foi enviada a uma repartição policial.

Desde o início de sua constituição, o Departamento de Assistência Social tornou-se a mola propulsora da CIP, não obstante a existência de diversos departamentos religiosos e culturais. Dividido em Setor Jurídico, Setor de Orientação, Setor Feminino e Lar das Crianças, esse departamento registrou a ajuda a 5.204 pessoas, em dez anos de funcionamento. A ajuda era dada em forma de auxilio financeiro, aconselhamento, apoio para o imigrante judeu legalizar sua situação no país e chamar parentes na Europa. Financeiramente, a parte mais substancial desse trabalho era a assistência médica e hospitalar e o sustento daqueles que ainda não haviam conseguido firmar-se na nova terra, comandadas pelo sub-departamento Relief.

"O custo da Assistência Médica desempenha um papel muito importante no financiamento da obra da Assistência Social. Muitos refugiados que ganham a sua vida não podem pagar os custos elevados de médicos, remédios ou hospitais; é por isso que temos de intervir em muitos desses casos" ${ }^{\text {"130 }}$

Até o ano de 1938, o cuidado aos recém-chegados durava, geralmente, poucos meses e o número total de pessoas assistidas pelo programa, naquele ano, variava entre 100 e 200. No entanto, a partir de 1939, com a crescente imigração de "turistas" e idosos, esse número superou o montante de 400 pessoas, vindo a baixar somente depois de 1941, em função, talvez, das dificuldades impostas pelo regime de Hitler àqueles que desejavam sair dos territórios ocupados pelo nazismo. Segundo a edição comemorativa do jornal Crônica Israelita, apenas no ano de 1939, 305 pessoas se beneficiaram com aquela assistência; dois anos depois, os beneficiados chegaram a 400, período que correspondia à intensificação das perseguições nazistas na Europa. Neste momento, a comunidade judaica brasileira e, em especial a CIP, mostrava-se aflita em relação aos familiares e amigos que dependiam da posse de um visto de entrada no Brasil para escapar do plano de extermínio sustentado pelo Terceiro Reich.

\footnotetext{
${ }^{128}$ Estatutos da Congregação Israelita Paulista, 1937. Pront. $n^{\circ} 4705$, da Congregação Israelita Paulista. DEOPS/SP. APESP.

${ }^{129}$ Ata da Reunião da Diretoria da Congregação Israelita Paulista. São Paulo, 22 de novembro de 1939. Fundo 187/AHJB.

${ }^{130}$ Relatório "Situação Financeira do Departamento de Assistência Social - no momento da transferência de fundos da Comissão dos três para a CIP”. São Paulo, 30 de setembro de 1942. Fundo Lorch/LEER USP.
} 
Em 1946, após o final da Segunda Grande Guerra, o número de auxiliados pelo Relief foi de apenas 56 pessoas, situação que pode ser avaliada como um interregno entre o fluxo imigratório anterior, conseqüência do anti-semitismo hitlerista e da guerra, e o início de um novo fluxo formado pelos deslocados de guerra e sobreviventes dos campos de concentração ${ }^{131}$.

As novas restrições à imigração instituídas pela Constituição de 1934, baseavam-se no sistema de quotas, que limitava o número de imigrantes de uma mesma nacionalidade a uma porcentagem máxima. Os judeus ficaram favorecidos, pois, enquanto grupo religioso com diferentes nacionalidades, poderiam obter vistos através de várias cotas, multiplicando o número de imigrantes de seu grupo. Ciente desta possibilidade, o governo brasileiro procurou novas fórmulas para cercear o ingresso de semitas no Brasil, mas sem tornar pública tal postura que o tornava conivente com a política anti-semita do III Reich ${ }^{132}$. Daí os cuidados dos Ministros das Relações Exteriores que atuaram entre 1937 e 1945, em editar circulares secretas que restringiam a impediam a entrada de judeus no Brasil. Em muitos casos, os diplomatas alegavam que a "quota estava esgotada", sem atender aos compromissos firmados pelo Brasil na Conferência de Evian. ${ }^{133}$ A questão humanitária ficava, assim, relegada a um segundo plano, prevalecendo a intolerância política.

Diante de tal alegação, os refugiados judeus procuravam entrar em território nacional portando um visto de turista que concedia noventa dias de permanência no Brasil. Para conseguir esta categoria de visto, muitos israelitas compravam passagens de ida e de volta, com o objetivo de atender aos requisitos impostos pela Circular Secreta $n^{\circ}$. 1229. Após o prazo de noventa dias, deveriam solicitar a legalização de sua situação no país e, caso houvesse disponibilidade na quota, garantiriam a prorrogação de sua permanência. No entanto, a constante sobrecarga das quotas, dificultava aos judeus refugiados a legalização de sua situação: muitos não dispunham de documentos de identificação regularizados, ou então, haviam usado cartas de chamada falsas. Alguns alegavam serem agricultores enquanto, na realidade, eram professores universitários ou técnicos interessados em se radicar nos grandes centros urbanos. O fato também, de

${ }^{131}$ Crônica Israelita 10 anos. Dezembro de 1946. Dez Anos de Construção da Congregação Israelita Paulista. Fundo 187/AHJB.

${ }_{132}$ Maria Luiza Tucci Carneiro. O Anti-semitismo na Era Vargas, Op.cit.

133 Ocorrida em 6 de julho de 1938, a Conferência de Evian fora convocada pelo Presidente americano Franklin D. Roosevelt em julho de 1938, para discutir o problema dos refugiados judeus. Apesar do encontro de trinta e dois países em Evian-les-Bains, França, a Conferência não obteve grandes resultados porque a maior parte dos países ocidentais relutou em aceitar judeus refugiados. Sobre essa questão, ver Maria Luiza Tucci Carneiro (org.). O Anti-semitismo nas Américas, Op.cit. 
serem apátridas, favorecia a classificação estereotipada de que eles eram pessoas "sem amor à pátria alguma”, expressão comum no moderno discurso anti-semita.

Nesse contexto, o setor jurídico da CIP teve importante atuação. Segundo Alice Hirschberg, a produção de cartas de chamada falsas foi uma ferramenta largamente empregada pela CIP, principalmente em 1938. Até esta data, a apresentação de uma carta de chamada, a partir de um parente ou amigo que pudesse se responsabilizar pelo imigrante, era condição para a obtenção de um visto de entrada no Brasil. Assim, na sede da Congregação, voluntários revezavam-se durante as madrugadas e finais de semana, reunindo documentos e preparando as "chamadas" que eram encaminhadas ao governo central no Rio de Janeiro, na esperança de um deferimento. Naquele ano, dos 600 pedidos de chamadas encaminhados, cerca de 200 teriam sido deferidos ${ }^{134}$, constituindo-se em verdadeiras "cartas de salvação".

Entre 1937 e 1942, além das centenas de cartas de chamada, mais de 2000 pessoas tiveram sua situação legalizada no país. Nos anos de 1939 e 1940, aqueles para os quais não fora possível conseguir a legalização no Brasil, foram enviados para os Estados Unidos ou para outros países da América do Sul, com as despesas parcialmente pagas pela $\mathrm{CIP}^{135}$.

A tentativa de legalização da permanência dessas pessoas que haviam entrado no Brasil com vistos de turistas, levou Frederico Zausmer, Salo Wissmann e Guilherme Krausz - sócios fundadores da Congregação Israelita Paulista - a lançar um apelo à Secretaria de Segurança Pública do Estado de São Paulo. Solicitavam, como medida de exceção, que todos os israelitas que tivessem entrado no país vindo como turistas até aquele ano de 1936, fossem autorizados a permanecer definitivamente no país. O Delegado de Ordem Social expediu então, uma nota declarando que achava "justo e humano" que se facilitasse a permanência dos israelitas alemães, contanto que os mesmos respondessem aos pré-requisitos necessários: atestado de residência, "prova de que possui bem imóvel no país no valor mínimo de 10:000\$000 ou declaração de estabelecimento bancário provando que tem em depósito a importância de 30:000\$000”. 136 Ou seja, os judeus poderiam ficar desde que pudessem contribuir financeiramente com o Brasil ou, pelo ou menos, não ocasionassem nenhum tipo de

\footnotetext{
${ }^{134}$ Alice Irene Hirschberg, Op.cit, p. 47.

135 Relatório "Situação Financeira Delegado Departamento de Assistência Social - no momento da transferência de fundos da Comissão dos três para a CIP". São Paulo, 30 de setembro de 1942. Fundo Lorch/LEER - USP.

${ }^{136}$ Informe do Delegado de Ordem Social. Delegacia de Ordem Política e Social. s/d. Pront. $n^{\circ} 36002$, de Frederico Zausmer. DEOPS/SP. APESP.
} 
despesa para o novo país. Considerando-se o valor exigido em conta bancária - três vezes o valor da casa - percebemos qual seria o tipo de imigrante que interessava às autoridades. Desprezava-se a difícil situação vivenciada por aqueles que, ao deixarem a Alemanha, não podiam trazer nada além de 9 marcos por pessoa, sendo que muitos haviam tido suas propriedades confiscadas pelos nazistas.

Endossando essa opinião, o Encarregado do Serviço de Fiscalização de Turistas declarou que tal medida se impunha naquele momento, para evitar que o Brasil fosse visto como um país que não amparava os desprotegidos "pela crença que abraçam e pela raça de que provém"137. Segundo ele próprio, o grande número de imigrantes irregulares presentes no Brasil, naquele momento, seria resultado de um "defeito de início no Serviço de Controle”, que não mais ocorreria. No entanto, apesar de todos os esforços, a medida não foi bem sucedida, pois, Fábio Masetto, responsável por decidir a sorte dos "turistas" israelitas, alegou que todos haviam entrado no Brasil como turistas e que, como tais, não desconheciam o prazo de permanência limitado, já que traziam consigo passagens de ida e volta: “(...) não resta, pois, a menor dúvida, que esses estrangeiros vieram com a idéia pré-concebida de burlar as leis do país". ${ }^{38}$ Assim, acatar as determinações do Delegado e do Encarregado de Serviço de Fiscalização seria impossível, já que tais incorriam contra as leis do país, "além de mau-precedente, a polícia do Estado contribuiria, nesse caso, para o franco desrespeito às leis do nosso país" ${ }^{139}$. O pedido inicial estava, por anteciapação, totalmente indeferido.

As questões das legalizações e dos pedidos de permanência em território nacional para aqueles que haviam chegado ao Brasil como turistas constituía um assunto delicado para a CIP. Nos primeiros anos de sua existência a Congregação preferia simplesmente aconselhar aqueles que a procuravam deixando as questões de ordem prática e legal ao cargo de despachantes particulares, que acreditava serem "de boa reputação e honestos”. Contudo, entre os anos de 1937 e 1938, a Comissão de Permanência de Estrangeiros com sede na Capital Federal, anulou todos os processos de legalização despachados pela polícia dos diversos estados do país até aquele momento, exigindo que todos os estrangeiros apresentassem novamente uma série de documentos a fim de poderem legalizar sua situação de maneira definitiva. Nesse momento, a CIP

\footnotetext{
${ }^{137}$ Informe do Encarregado do Serviço de Fiscalização de Turistas. s/d. Pront. $n^{o}$ 36002, de Frederico Zausmer. DEOPS/SP. APESP.

${ }^{138}$ Informe de Fábio Masetto, Superintendente de Ordem Política e Social. s/d. Pront. $n^{o}$ 36002, de Frederico Zausmer DEOPS/SP. APESP.

${ }^{139}$ Idem.
} 
percebeu que muitos despachantes queriam aproveitar-se da situação de angústia em que se encontravam os imigrantes: cobravam valores abusivos pelos seus serviços, instituindo um esquema comercial que englobava também os certificados de "chamadas".

Considerando que muitos dos imigrantes judeus não possuíam recursos para ir ao Rio de Janeiro resolver problemas pertinentes à sua permanência e, nem ao menos sabiam falar o português, a CIP, ao final de 1938, decidiu colocar todo o seu aparelho administrativo à disposição de seus correligionários. Contratou um advogado renomado, e anunciou que cobraria pelo serviço apenas as quantias referentes às traduções de documentos necessários ao processo, ao material utilizado e ao reconhecimento de firmas. Os despachantes, prejudicados em seu "comércio" pela atuação da Congregação, começaram então a difamar essa instituição frente às autoridades cariocas e paulistanas, chamando-a de gananciosa e desonesta.

A situação induziu Ludwig Lorch, em janeiro de 1939, a preparar um relatório sobre as finalidades da Congregação, desde sua fundação, explicando quais seriam os verdadeiros motivos que a levavam a encabeçar os processos de legalização e permanência de seus associados e auxiliados: "Os congregados da CIP não podem aconselhar-se nos seus respectivos consulados e eis mais um motivo porque a CIP se julga não somente no direito, mas no dever de ajudar e auxiliar em tudo esses imigrantes. ${ }^{140}$. O relatório era dirigido ao Dr. Vampré, advogado, para que o mesmo tomasse as providências cabíveis ao caso e esclarecesse, junto às autoridades brasileiras, qual seria o verdadeiro posicionamento da CIP:

"Estas explicações tem por fim esclarecer, uma vez para sempre a posição da CIP perante as autoridades brasileiras, acabando de vez com as explorações, difamações e acusações que pessoas menos escrupulosas espalham, agindo por instintos baixos e procurando aproveitarem-se da situação infeliz de muitas pessoas em seu próprio proveito." 141

Mudanças na legislação e a imposição de novas restrições dificultavam constantemente os processos de legalização. Entre 1933 e 1940, imigraram para o Brasil, aproximadamente, de 15.000 a 18.000 refugiados. Ao final do ano de 1937, início do Estado Novo varguista, o governo brasileiro ameaçou expulsar do Brasil cerca de 2.000 refugiados que não possuíam vistos permanentes. Diante de reclamações de

\footnotetext{
${ }^{140}$ Relatório $O$ que é a Congregação Israelita Paulista? São Paulo, janeiro de 1939. Fundo Ludwig Lorch, LEER-USP.

${ }^{141}$ Idem.
} 
toda a comunidade judaica, foi permitido que aqueles que houvessem entrado no país antes o dia 21 de dezembro de 1938, apresentassem um requerimento para legalização. Encaminhados esses requerimentos, aos interessados era permitido trabalhar para prover o seu próprio sustento. Deste primeiro grupo, era sabido, em 1940, que apenas 600 pessoas haviam conseguido a legalização, enquanto o restante aguardava conhecer o desfecho de sua trajetória ${ }^{142}$.

Entre o dia 21 de dezembro de 1938 e o início de 1941, mais 2.600 judeus ingressaram ao Brasil ${ }^{143}$. Todos portavam apenas vistos para turismo e haviam entrado no país ainda sob a vigência do Decreto-lei $\mathrm{n}^{\circ} 406$, de maio de 1938, cujo artigo 12 permitia a permanência em território nacional daqueles que haviam chegado com vistos temporários:

"Art. 12 - Os estrangeiros vindos para o Brasil em caráter temporário compreendem as seguintes categorias:

a) turistas e visitantes em geral e estrangeiros em trânsito;

b) representantes de firmas comerciais estrangeiras e os que vierem em viagem de negócios;

c) artistas, conferencistas, desportistas e congêneres.

Parágrafo único - Os estrangeiros classificados neste artigo poderão tornar permanente sua estada no território nacional, satisfeitas as exigências que forem estabelecidas no regulamento da presente lei". ${ }^{144}$

Esse segundo grupo, porém, não poderia trabalhar enquanto sua situação no país não estivesse legalizada. Restava, pois, à beneficência judaico-brasileira manter esses indivíduos, situação que preocupava seus dirigentes devido ao alto volume de recursos necessários para tal. Em agosto de 1939, entrou em vigor o Decreto-lei nº1532, com eficiência retroativa e visando suspender a execução do art.12 do Decreto-lei $n^{\circ} 406$. A partir daquele momento, a permanência definitiva seria concedida apenas àqueles que conseguiram vistos através de processos de chamada feitos no Ministério das Relações Exteriores; aos técnicos contratados ou estabelecidos com indústria própria, aos cientistas ou artistas com merecimento excepcional; aos "capitalistas que efetivamente empregarem capitais nas indústrias de interesse nacional”. ${ }^{145}$ Deste modo, aqueles que tivessem imigrado entre 1939 e 1940, além de não poderem trabalhar em território nacional, perdiam também o direito de se legalizarem no país.

\footnotetext{
${ }^{142}$ Relatório: Situação precária de um certo número de refugiados israelitas no Brasil. Congregação Israelita Paulista. São Paulo, s/d. Fundo Ludwig Lorch, LEER-USP.

143 Idem.

${ }^{144}$ Decreto-lei 406 de 4/05/1938. Dispõe sobre a entrada de estrangeiros no território nacional.

${ }^{145}$ Relatório de Ludwig Lorch para a Congregação Israelita Paulista. s/d. Fundo Ludwig Lorch, LEERUSP.
} 
"Embora estritamente vedado o trabalho remunerado ou lucrativo a todas as pessoas do grupo $\mathrm{n}^{\circ} 2$, muitos entre eles procuram clandestinamente ganhar algum dinheiro e tornam-se assim criminosos perante a lei. Os outros, mais escrupulosos, acham-se num estado de grande desespero e muitos decaem moralmente, devido à inatividade a que a lei os obriga" 146

Havia ainda um meio de "comprar" a permanência no Brasil pelo período de um ano: bastava efetuar o pagamento de um selo no valor de um conto de réis e depositar no Banco do Brasil uma quantia suficiente para promover a subsistência do imigrante no país. Ainda segundo o decreto de agosto de 1939, o estrangeiro que não cumprisse com as determinações propostas tornar-se-ia, automaticamente, um infrator das leis brasileiras, devendo ser preso e colocado à disposição do Ministério da Justiça e Negócios Interiores. Ao final do processo, o indivíduo poderia ser deportado ou recolhido a uma colônia penal agrícola. ${ }^{147}$

As novas resoluções do governo federal atingiam diretamente os refugiados judeus da Segunda Guerra Mundial:

"Os estrangeiros vindos da Alemanha ou dos países sob domínio alemão, em virtude das condições aí existentes, só podiam trazer consigo a quantia de dez marcos. Como, porém, se viram obrigados a abandonar seus países de origem sob a pressão da Gestapo, tiveram de aceitar qualquer visto que pudessem obter, mesmo temporário, confiando nas disposições da lei brasileira que lhes permitia obter depois a permanência definitiva. Tanto maior o golpe que lhes foi desferido pela súbita revogação da lei. Pensavam poder ser sustentados durante um certo tempo pelas associações filantrópicas, e manterse depois de legalizados com os frutos de seus próprios trabalhos". ${ }^{148}$

Sem dinheiro, os refugiados judeus não tinham como continuar a viver no Brasil. Acostumados com a vida nas cidades, desesperavam-se ao saber que corriam o risco de ser internados em colônias penais agrícolas, situação que, em suas mentes, seria análoga à prisão em campos de concentração: “Em caso em que eles sejam mandados para colônias penais espera-os uma sorte trágica e sem dúvida para muitos deles, fatal" ${ }^{49}$. Nas palavras de Ludwig Lorch, em 1941, em informe ao Comitê Central do JOINT em Nova York:

\footnotetext{
146 Relatório: Situação precária de um certo número de refugiados israelitas no Brasil. Congregação Israelita Paulista. São Paulo, s/d. Fundo Ludwig Lorch, LEER-USP.

147 Decreto-lei 1532 de 23/08/1939. Suspende a execução do art. 12, parágrafo único, do Decretolei número 406, de 4 de maio de 1938.

148 Relatório de Ludwig Lorch para a Congregação Israelita Paulista. s/d. Fundo Ludwig Lorch, LEERUSP.

${ }^{149}$ Relatório: Situação precária de um certo número de refugiados israelitas no Brasil. Congregação Israelita Paulista. São Paulo, s/d. Fundo Ludwig Lorch, LEER-USP.
} 
"A situação geral tornou-se ainda pior. Eu trago algumas informações que podem dar a você um quadro claro de como as coisas estão. Desnecessário dizer que as pessoas estão muito desesperadas frente ao perigo de serem internadas em colônias penais agrícolas. Isto significa algo em um país tropical". ${ }^{150}$

A situação daqueles cujas vidas dependiam de sua emigração da Europa se complicaria, ainda mais, entre os anos de 1940 e 1941, momento em que as restrições impostas pelo governo brasileiro causavam uma sensível diminuição na entrada de refugiados no país. Essa situação seria agravada pela promulgação do Decreto-lei $\mathrm{n}^{\circ} 3175$ que restringia, quase que totalmente, a imigração:

“Art. $1^{\circ}$ Fica suspensa a concessão de vistos temporários para a entrada de estrangeiros no Brasil (...)

$\S 1^{\circ} \mathrm{Em}$ qualquer caso, é indispensável que o estrangeiro esteja, de direito e de fato autorizado a voltar ao Estado onde obtém o visto, ou ao Estado de que é nacional, dentro do prazo de dois anos a contar da data de sua entrada no território brasileiro.

$\S 2^{\circ} \mathrm{O}$ visto de trânsito a que se refere o art. 25 , letra a, do decreto $\mathrm{n}^{\circ} .3 .010$, de 20 de agosto de 1938, será válido por 60 dias.

Art. $2^{\circ}$ Fica suspensa igualmente a concessão de vistos permanentes". ${ }^{151}$

Segundo dados oficiais do Departamento de Imigração do Ministério do Trabalho, Indústria e Comércio brasileiro, em 1941, foram concedidos um total de 259 vistos para alemães que se declaravam judeus, entre autorizações temporárias e permanentes. Apenas dois anos antes, em 1939, o número de vistos deferidos para a mesma categoria de imigrantes chegava a $2.357^{152}$. As restrições colaboraram para a existência dos "navios errantes", que vagavam pelos oceanos Atlântico e Pacífico em busca de um porto que aceitasse o desembarque de seus passageiros, em sua maioria, judeus refugiados. Nesse contexto, cabia às associações, como a CIP, a tentativa de interseção junto ao governo federal a fim de decidir a sorte daqueles viajantes.

Logo no início de 1941, as atenções da CIP e da associação judaico-carioca UNIAO - Associação Beneficente Israelita do Rio de Janeiro - voltaram-se para a proibição do desembarque, nos portos do Rio de Janeiro e em Santos, de 16 judeus a bordo do navio Montevidéu Marú. Nacionais da Alemanha, os viajantes deixaram

150 "The general situation has become still worse. I forwarded some information which will give you a clear picture of how things are. Needless to say that people are very desperate in face of the danger to be interned into agricultural penal colonies. This means something in a tropical country" Carta de Ludwig Lorch para Frederick W. Borchard c/o para American Jewish JOINT Distribution Committee, Cidade de Nova York. São Paulo, 31 de maio de 1941. Fundo Ludwig Lorch, LEER-USP.

${ }^{151}$ Decreto-lei $n^{\circ} 3175$ de 7/04/1941. Restringe a imigração e da outras providências.

152 Dados Oficiais: Imigração Judaica para o Brasil 1939-1941. Ministério do Trabalho, Indústria e Comércio. Departamento Nacional de Imigração. In: Maria Luiza Tucci Carneiro. O Anti-semitismo na Era Vargas, Op. cit, p. 405. 
Berlim e partiram para o Japão através da Rússia, atravessando toda a região da Sibéria e da Manchúria. No Japão, embarcaram no referido navio rumo ao Haiti, pois, possuíam vistos válidos para esse país, além de vistos de trânsito panamenhos. Sua intenção era chegar aos Estados Unidos, onde possuíam parentes e amigos. No entanto, chegando ao Panamá, as autoridades responsáveis pela zona do canal permitiram que apenas quatro passageiros desembarcassem, enviando o restante diretamente para o Haiti. Não obstante, ao chegarem nesse país os refugiados foram impedidos de desembarcar sob a alegação de que aquele país não permitiria sua entrada. Assim, em dezembro de 1940, a Sociedade Hebréia de Beneficência do Panamá enviou um pedido de ajuda às associações judaicas de São Paulo e Rio de Janeiro, na tentativa de conseguir que os viajantes desembarcassem no Brasil. Além disso, a organização panamenha solicitava que fossem levadas comida e água para os 12 passageiros a bordo do Montevidéu Marú, cuja situação tornava-se pior a cada dia.

Em contato constante, as principais associações judaico-brasileiras organizaramse no sentido de ajudar aqueles viajantes conforme prosseguia sua travessia ao longo do litoral brasileiro. Na Bahia, Julius Strauss garantiu a alimentação e os cuidados necessários àqueles passageiros; no Rio de Janeiro esse mesmo auxílio foi efetuado pela associação UNIAO através de Max Stern; em Santos, o casal Lorch e a Srta. Katzenstein zelaram por aqueles homens e mulheres durante os dois dias em que o Montevidéu Marú esteve ali ancorado ${ }^{153}$.

Vários esforços foram feitos pela Congregação na tentativa de desembarcar esses doze indivíduos no Brasil: Ludwig Lorch foi pessoalmente ao Rio de Janeiro a fim de resolver a questão junto às autoridades competentes. Além disso, o Presidente da CIP providenciou o envio de uma carta ao CIC na qual expôs todo o ocorrido com aquele grupo de refugiados e pleiteou o desembarque dos mesmos no porto do Rio de Janeiro, até que conseguissem vistos para outro país. A fim de garantir o deferimento do pedido, a carta trazia uma relação como nome, idade e profissão de 12 dos viajantes, demonstrando que não se tratavam de imigrantes comuns, mas de industriais e comerciantes, além de um médico e um jurista ${ }^{154}$. Apesar da tentativa, em 14 de janeiro de 1941, os doze refugiados foram impedidos de desembarcar no Rio de Janeiro e

\footnotetext{
${ }^{153}$ Relatório do setor administrativo da Congregação Israelita Paulista sobre as atividades realizadas em 1941. São Paulo, dezembro de 1941. Fundo Ludwig Lorch, LEER-USP.

${ }^{154}$ Carta de Ludwig Lorch, Presidente da Congregação Israelita Paulista, para o Presidente do Conselho de Imigração e Colonização. s/d. Fundo Ludwig Lorch, LEER-USP.
} 
prosseguiram viagem rumo à Montevidéu (Uruguai), país que declarara poder recebêlos.

Não obstante, dias antes de o vapor aportar no Uruguai, o jornal United Press divulgou a notícia exagerada de que o Brasil havia proibido o desembarque de 300 refugiados a bordo do Montevidéu Marú. "Sob a pressão moral daquela noticia espalhafatosa, falsa sob todos os aspectos, as autoridades competentes uruguaias revogaram sua permissão de desembarque, e os doze desgraçados continuam a bordo" ${ }^{155}$. Tal notícia fora, nesse momento, veiculada também no Brasil através do jornal O Estado de São Paulo, na Argentina e, até mesmo, nos Estados Unidos. Após vagar durante meses através dos oceanos Pacífico e Atlântico, os viajantes puderam, finalmente, desembarcar em Buenos Aires (Argentina).

Tucci Carneiro chamou a atenção, em O Anti-semitismo na Era Vargas, para o episódio do navio espanhol Cabo de Hornos. Em 20 de outubro de 1941, os 90 judeus presentes entre os seus passageiros ${ }^{156}$ foram impedidos de desembarcar no Rio de Janeiro “devido à objeção por parte das autoridades marítimas”. Todos eles portavam vistos temporários ou permanentes ainda válidos para o ingresso em território nacional. Em relatório presente entre a documentação pessoal do Presidente da Congregação Israelita Paulista, os 90 passageiros judeus são classificados de acordo com sua procedência e com o tipo de vistos que possuíam. Uma parte desses viajantes havia embarcado em Marselha (França), em dezembro de 1940, a bordo do navio Alsina portando vistos válidos para o Brasil. No entanto, o "vapor" chegara apenas até Dakar (Senegal), sendo proibido de prosseguir por causa de um bloqueio inglês. Durante meses, os viajantes ficaram em “campos de concentração na África do Norte” ${ }^{157}$, prosseguindo viagem apenas quando o Cônsul brasileiro em Casablanca (Marrocos) aceitou prorrogar os seus vistos. Chegando ao Brasil, tanto no porto do Rio de Janeiro como no porto de Santos, os passageiros foram impedidos de desembarcar, pois a prorrogação de seus vistos não foi considerada válida. ${ }^{158}$

\footnotetext{
${ }^{155}$ Relatório do setor administrativo da Congregação Israelita Paulista sobre as atividades realizadas em 1941. São Paulo, dezembro de 1941. Fundo Ludwig Lorch, LEER-USP.

156 Em O Anti-semitismo na Era Vargas, Maria Luiza Tucci Carneiro cita documentos oficiais que afirmam a existência de 95 judeus a bordo do navio Cabo de Hornos. Adotamos, no entanto, os números aceitos pela Congregação Israelita Paulista, e fixamos em 90 o número de passageiros judeus no referido navio.

${ }^{157}$ Relatório da Congregação Israelita Paulista. 1941. Fundo Ludwig Lorch, LEER-USP.

${ }^{158}$ Esta questão referente ao vapor Cabo de Hornos foi tratada por Tucci Carneiro e, posteriormente, por Jeffrey Lesser, op.cit. p. 243 a 247.
} 


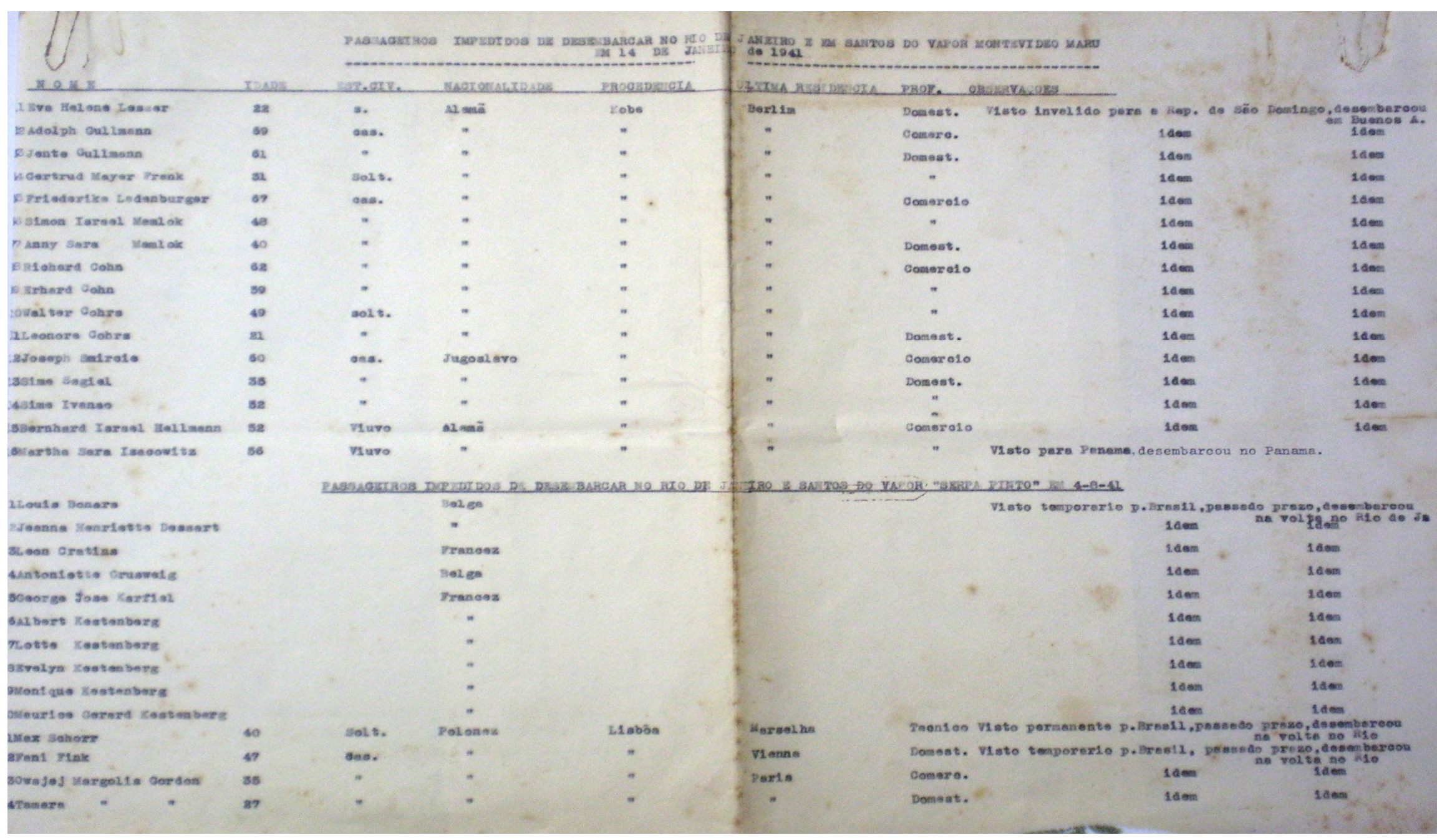

- Lista dos passageiros impedidos de desembarcar no Rio de Janeiro e em Santos do vapor Montevidéu Marú em 14 de janeiro de 1941 ; Lista dos passageiros impedidos de desembarcar no Rio de Janeiro e em Santos do vapor Serpa Pinto em 4 de agosto de 1941. Fundo Ludwig Lorch, LEERUSP. 
Um segundo grupo daqueles refugiados possuía vistos diplomáticos concedidos por Luiz Martins Souza Dantas, da Embaixada Brasileira em Vichy (França). A prorrogação desses vistos criou uma divergência entre o Conselho de Imigração no Rio de Janeiro, a Embaixada e o Ministério das Relações Exteriores acerca de sua validade, além de um processo administrativo contra Souza Dantas, acusado por cometer irregularidades $^{159}$.

O terceiro e último grupo dos refugiados portava vistos válidos para o Brasil concedidos com autorização especial do Ministério das Relações Exteriores. Não obstante, foram impedidos de desembarcar por causa de alterações recentes na lei de imigração, que só permitia a entrada de agricultores, técnicos especializados ou capitalistas que apresentassem a quantia de 400 contos de réis.

"Como se vê em todos estes casos os passageiros podiam ou mesmo tinham de confiar na validade dos seus vistos e de forma alguma podem ser responsabilizados ou punidos por alterações de leis ou por interpretações divergentes entre as autoridades marítimas de um lado e consulares do outro." 160

Segundo Tucci Carneiro, o problema com os passageiros do Cabo de Hornos não se resumia a mudanças na legislação e desentendimentos entre os funcionários federais. Tratava-se de uma tentativa das autoridades políticas e policiais em evitar a entrada de "semitas" em território nacional. Os passageiros judeus do navio eram, sem sua maioria, adultos e nacionais da Tchecoslováquia e Polônia. Haviam embarcado em Cádiz, Espanha, na esperança de aqui recomeçarem suas vidas destruídas em seus países de origem. Diante de sua situação, em 6 novembro de 1941, Horácio Lafer, em nome da CIP, enviou por telegrama um apelo para Getúlio Vargas, endereçado diretamente ao Palácio do Catete:

"Peço venha apelar sentimento piedade V. Excia. Sentido permitir desembarque passageiros vapor Cabo Hornos cuja permissão entrada Brasil terminou prazo motivos força maior. Coração generoso V. Excia. Certamente ditará solução possível afim evitar tantas infelicidades. Atenciosas saudações."161

A resposta de Getúlio Vargas seria dada apenas dois dias depois, quando ordenou que o Cabo de Hornos seguisse seu caminho para Trinidad, já que o desembarque dos

\footnotetext{
${ }^{159}$ Ver Fábio Koifman. Op.cit.

${ }^{160}$ Relatório da Congregação Israelita Paulista. 1941. Fundo Ludwig Lorch, LEER-USP.

161 Telegrama de Horácio Lafer, Vogal da Congregação Israelita Paulista, para Getúlio Vargas, Presidente do Brasil. São Paulo, 6 de novembro de 1941. Fundo Lorch, LEER-USP.
} 
judeus violaria as leis brasileiras de imigração ${ }^{162}$. Sabemos que, após essa recusa, o navio partiu para Curaçao, seu destino final ${ }^{163}$.

Um pequeno grupo, de 14 pessoas, entre aqueles que ficaram detidos por meses em Dakar, arriscaram voltar para Portugal e embarcar no vapor Serpa Pinto, rumo ao Brasil. Chegaram aos portos do Rio de Janeiro e de Santos no inicio de agosto de 1941, onde foram impedidos de desembarcar devido ao vencimento de seus vistos para turismo. Nos dias subseqüentes, coube aos senhores Horácio Lafer, Ludwig Lorch e Paulo Zander o envio de telegramas ao Presidente do Conselho de Imigração e Colonização e ao próprio Presidente da República:

“A Congregação Israelita Paulista e a União Associação Beneficente Israelita do Rio de Janeiro vem solicitar generosa atenção V. Excia. Para sorte quatorze refugiados entre os quais três crianças tenra idade chegados hontem porto de Santos bordo vapor Serpa Pinto e impedidos desembarcar em virtude expiração seus vistos temporários (...). Situação dolorosa desses infelizes refugiados ameaçados retornar horrores Europa convulsionada, pois navio regressa diretamente de Santos, poderá ser obviada por gesto humanitário autorizando desembarque (...). Essas instituições , assegurando V. Excia, que assumirão responsabilidade encaminhamento e subsistência dessas pessoas..."

Os pedidos, dessa vez, fizeram efeito: os 14 refugiados foram autorizados a desembarcar no Rio de Janeiro, de onde o vapor partiu de volta para a Europa.

É certo que um país autônomo tem o direito de instituir uma legislação imigratória adequada aos seus anseios, quaisquer que sejam eles. Mas, num momento de exceção, como o fora a Segunda Guerra Mundial, não seria mais prudente e, até mesmo humanitário, facilitar o desembarque daqueles que fugiam do nazismo? Como poderia um refugiado, vítima do anti-semitismo nazista, permanecer apenas dois anos no Brasil, sendo sustentado por alguma instituição, ou por parentes e amigos, para depois retornar ao seu país de origem? Autores como Tucci Carneiro, Avraham Milgran e Fábio Koiffman concordam ao afirmar que tais restrições não se deviam apenas à inabilidade política, por parte do governo brasileiro, e ao desconhecimento da situação européia, mas sim, faziam parte de uma estratégia governamental que visava afastar do país levas de refugiados judeus. Tais restrições aplicavam-se principalmente àqueles provenientes

\footnotetext{
${ }^{162}$ Maria Luiza Tucci Carneiro. O Anti-semitismo na Era Vargas, Op. cit, p. 157.

${ }^{163}$ Lista dos passageiros impedidos de desembarcar no Rio de Janeiro do vapor Cabo de Hornos em 20 de outubro de 1941; Lista dos passageiros impedidos de desembarcar em Santos do vapor Cabo de Hornos em 21 de outubro de 1941. Fundo Lorch/LEER - USP.

164 Telegrama de Horácio Lafer, Ludwig Lorch e Paulo Zander para Getúlio Vargas, Presidente do Brasil, e para o Presidente do Conselho de Imigração no Rio de Janeiro. São Paulo, 8 de agosto de 1941. Fundo Ludwig Lorch, LEER-USP.
} 
da Europa e só foram revogadas em 1945, ao final da Segunda Guerra, através do Decreto-lei $\mathrm{n}^{\mathrm{o}}$. 7.575, que considerou como:

"cessados os motivos de ordem política que levaram o governo a restringir a entrada de estrangeiros em território nacional e por lhe parecer conveniente facilitar desde já a imigração dos países europeus para o Brasil..."

Apesar das dificuldades impostas pelo governo brasileiro à imigração judaica, Hans Hamburger afirmou em edição comemorativa do jornal Crônica Israelita ${ }^{166}$ que, em geral, as tentativas de legalização de imigrantes feitas pela CIP foram bem sucedidas. Entre as 5.204 pessoas auxiliadas pelo setor de assistência social nos primeiros dez anos da Congregação, cerca de 1.800 haviam imigrado para o Brasil com vistos temporários. Destes, apenas 150 pessoas não conseguiram legalizar sua situação, sendo obrigados a deixar o país ${ }^{167}$. Tais extradições aconteceram no final de 1937 , apogeu do Estado Novo brasileiro e, no final de 1946, quando a ditadura varguista já havia dado lugar à pseudo-democracia do governo Dutra.

Ao Setor de Orientação da CIP cabia receber os recém-chegados e proporcionarlhes as condições necessárias para seu sustento e de sua família, cuidados médicos e orientação profissional. Esse setor também era o responsável pelo cuidado com os casos de migração pelo país, "ramo esse que, em 1939 e 1940, foi administrado por um departamento especial, quando foi feita uma tentativa de organizar uma migração maior para o interior do país. Essa tentativa, porém, não teve o sucesso desejado” 168. Nesses dois anos, a Congregação tentou encontrar possibilidades de trabalho remunerado em outros estados e municípios brasileiros, de modo a garantir o sustento dos imigrantes nos setores de agricultura, trabalho manual e na técnica industrial. Acreditava-se que no interior do país faltassem homens e mulheres capazes de

\footnotetext{
${ }^{165}$ Decreto-lei $n^{\circ} 7.575$ de 21 de maio de 1945. Regula o Decreto-lei $n^{o}$. 3.175, de 7 de abril de 1941.

166 A Crônica Israelita, órgão de informação da CIP, circulou entre setembro de 1938 e 1969, sem que houvesse interrupções. Nasceu em meio às incertezas do Estado Novo e, inicialmente, era publicado em alemão. Seu primeiro diretor foi o bibliotecário Herbert Gertsmann, mas quem se consagrou a frente desse periódico foi Alfred Hirschberg que o assumiu entre 1940 e 1969. Ver Maria Luiza Tucci Carneiro, Boris Kossoy (orgs.) A Imprensa Confiscada pelo DEOPS, 1924-1954. São Paulo: Imprensa Oficial/Ateliê Editorial, 2003.

${ }^{167}$ Crônica Israelita 10 anos. Dezembro de 1946. Dez Anos de Construção da Congregação Israelita Paulista Fundo 187/AHJB.

${ }^{168}$ Relatório "Situação Financeira do Departamento de Assistência Social - no momento da transferência de fundos da Comissão dos três para a CIP”. São Paulo, 30 de setembro de 1942. Fundo Lorch/LEER USP.
} 
desenvolver economicamente a região, enquanto, nas cidades, o acúmulo de mão-deobra dificultava a colocação profissional dos recém-chegados.

Nesse intuito, a CIP elaborou um questionário detalhado sobre o custo de vida e as perspectivas de trabalho dos diferentes municípios brasileiros, a fim de que os mesmos fossem respondidos por judeus já estabelecidos nas deferentes regiões. Com perguntas feitas em alemão e português, procurava-se descobrir se na cidade existiria água encanada, eletricidade, gás, sistema de esgoto e telefone; qual seria o seu clima; o preço de um aluguel para uma casa de três cômodos; o custo da alimentação para uma família com duas, três ou quatro pessoas; os preços de artigos como manteiga, carne e ovos; a presença, ou não, de assistência médica, ginásios esportivos, instituições culturais e cursos profissionalizantes. Além disso, para que a vida em comunidade não fosse esquecida, era necessário também conhecer o número de famílias judias radicadas na região; a possibilidade de se instalar novos imigrantes judeus, temporariamente, nas casas dessas famílias; se haveria a presença de um rabino no local; a continuidade das tradições, a realização das principais festas religiosas e a existência de escolas judaicas. ${ }^{169}$

$\mathrm{Na}$ tentativa de cumprir com uma das principais exigências no governo varguista em relação aos novos imigrantes, a CIP inquiria também, sobre as possibilidades de fixação nas zonas agrícolas do interior do Brasil: haveriam judeus já estabelecidos nessas zonas? As mesmas constituiriam uma boa possibilidade de sustento? Quais culturas seriam as mais produtivas naquele local $?^{170}$ Todavia e, a despeito de tantos esforços, a comunidade judaico-brasileira continuou a desenvolver-se em proximidade com as principais capitais do país, Rio de Janeiro, São Paulo e Porto Alegre, cidades que ofereciam melhores condições de subsistência e postos de trabalho mais apropriados ao nível educacional e cultural dos judeus emigrados da Europa ocidental.

A garantia de uma ocupação que pudesse prover o sustento do imigrante e de sua família constituía, assim, uma das principais preocupações dos dirigentes da Congregação. Recebido por representantes da comunidade logo após o seu desembarque no Porto de Santos, o recém-chegado era transladado para São Paulo, geralmente de trem. Na capital, era encaminhado às pensões judaicas e orientado a frequientar as aulas de português. Calcula-se que, entre 1937 e 1946, mais de 1.000 imigrantes tenham sido

\footnotetext{
${ }^{169}$ Questionário - Fragebogen. Congregação Israelita Paulista. São Paulo, 1939. Fundo Lorch,/LEER USP. ${ }^{170}$ Idem.
} 
beneficiados com as aulas de língua portuguesa oferecidas pela $\mathrm{CIP}^{171}$. Estas aulas foram reiniciadas após 1946 com o objetivo de atender ao novo fluxo de refugiados do pós-guerra. Além das aulas, os imigrantes eram aconselhados sobre quais seriam as melhores profissões para este recomeço de vida e quais caminhos deveriam seguir para conseguir um emprego ou iniciar o seu próprio negócio.

Visando facilitar a contratação e conhecer os atributos profissionais de toda a comunidade judaica, especialmente dos recém-chegados, a Congregação elaborava uma espécie de currículo no qual constava a idade, a data de chegada ao Brasil e toda a experiência profissional do indivíduo. Tais currículos acabavam sendo utilizados, também, para contratar os funcionários necessários à própria Congregação. Mesmo aqueles já radicados e adaptados ao Brasil, desempregados ou não, elaboravam e enviavam seus currículos para a CIP:

"Heinz Arno Hirsch

33 anos de idade.

Está no Brasil desde 1936, visto permanente.

Trabalhei na Alemanha durante 5 anos num escritório de exportação e 8 anos com a casa 'Woolworth, como chefe de vendas. No Brasil trabalhei como chefe de vendas na Lojas Brasileiras, depois conferente no Mappin Stores e, desde dezembro de 1938, para a ICA do Rio de Janeiro até a dissolução do escritório em São Paulo. Atualmente está ocupado na secretaria da Irmandade B' Nai B'rith. Crê que possue grande experiência na estatística, propaganda e serviços internos de escritório." 172

Existiam ainda, fundos especiais do JOINT concedidos para a abertura de pequenas empresas, "sem a necessidade de fiadores ou outras seguranças"173. Em alguns casos, tentava-se arrumar uma ocupação para o recém-chegado dentro da própria comunidade e, enquanto isso não acontecia, o mesmo era sustentado pela Congregação através de empréstimos.

Havia um caminho pré-estabelecido para que um empréstimo fosse concedido. $\mathrm{O}$ pretendente deveria preencher um formulário elaborado pela CIP, cujos campos solicitavam dados pessoais e da família do proponente, profissão, destino do empréstimo, se possuía alguma renda e, se positivo, de qual valor. Além disso, deveria indicar o nome de pelo ou menos, dois fiadores para que o empréstimo fosse

${ }^{171}$ Crônica Israelita 10 anos. Dezembro de 1946. Dez Anos de Construção da Congregação Israelita Paulista. Fundo 187/AHJB.

${ }^{172}$ Currículo de M. Schwartzman e Heinz Arno Hirsch. Congregação Israelita Paulista. São Paulo, 13 de maio de 1940. Fundo Lorch/LEER - USP.

${ }^{173}$ Relatório "Situação Financeira do Departamento de Assistência Social - no momento da transferência de fundos da Comissão dos três para a CIP”. São Paulo, 30 de setembro de 1942. Fundo Lorch/LEER USP. 
concedido $^{174}$. Os empréstimos variavam em quantia e finalidade: alguns se destinavam ao sustento de uma família, enquanto outros serviriam apenas para cobrir despesas médicas. Muitos destes recursos relacionavam-se às despesas gastas com a legalização de imigrantes, chegados ao Brasil sem a posse do visto permanente. Após a concessão do benefício, a Congregação formava, para cada um dos auxiliados, uma espécie de prontuário no qual constavam todos os dados do beneficiado e a quantia a ser ressarcida à CIP. Em alguns casos, eram elaboradas listagens que expressam a preocupação da comunidade com o andamento da vida de seus membros e auxiliados:

"6.11.1939 Krs. Aronowicz, Edith - O marido não sustenta mais a sua família (esposa e filho) perdeu o dinheiro ao jogo. Elle vendeu todos os móveis, ella só ficou com a roupa, motivo que ella deixou o esposo. A. recebe Rs. $150 \$ 000$ para si e seu filho de dez anos. Sobre emprego vai falar com as Sras. Ettlinger e Wachtel" ${ }^{175}$

A devolução do empréstimo poderia ser feita em parcelas mensais e, era solicitada apenas quando o beneficiado se encontrava numa situação financeira confortável e ajustada, podendo dispor daquela quantia sem prejuízo algum. Porém, muitos assistiram à incapacidade de devolver o empréstimo. Segundo anotação da CIP, o Sr. Adolf Schiller:

"Chegou no Brasil no mez de julho de 1939, junto com a esposa Charlotte. O casal se dirigiu a nós imediatamente da chegada, pedindo o nosso auxílio. Mantemos o casal Sch. Durante os primeiros 6 meses. Também pomos a disposição do snr. Sch. Todas as despesas para os processos de legalização, como também pagamos os custos das duas carteiras, i. é de Rs. $400 \$ 000$.

O saldo da conta de Schiller é de 3:292\$500. Observamos que o snr. Sch, já começou reembolsar à sua dívida a importância de Rs. $96 \$ 000$ (em prestações mensais).

O casal Sch. Consertou meias e ganhou a sua vida com esta atividade. - Concedemos o nosso último auxílio no mez de maio de 1941"176.

Através da documentação do AHJB e do Fundo Lorch/LEER -USP constatamos que a ajuda concedida aos imigrantes ia desde o embarque na Europa, através da CIP e do JOINT que providenciavam documentos, passagens e vistos, até o desembarque no porto de Santos (SP). A alusão ao pagamento de despesas relativas à legalização demonstra a posse, pelo casal Schiller, de vistos para turistas ou de trânsito. Os vistos de trânsito referem-se àqueles concedidos para que o imigrante passasse pelo Brasil na

\footnotetext{
${ }^{174}$ Requerimento de proposta de empréstimo - Congregação Israelita Paulista, s/d. Fundo Lorch/LEER USP.

${ }^{175}$ Informe da CIP. São Paulo, 6 de novembro de 1939. Fundo Lorch /LEER - USP.

${ }^{176}$ Pront. de Adolf Schiller. Secção de Serviço Social da Congregação Israelita Paulista; Casos atendidos - 1939 a 1946. Fundo 187/AHJB.
} 
necessidade de chegar a outros países da América do Sul, como Argentina e Uruguai, por exemplo. No entanto, muitos indivíduos, tendo o Brasil com destino preferencial, ao transitar pelo país desembarcavam e tornavam-se imigrantes ilegais, situação que lhes dificultava o exercício oficial de qualquer profissão. Muitos foram aqueles que, sem poder atuar publicamente como médico, dentista, engenheiro, professor - dentre outras profissões liberais, acabavam recomeçando a vida como um vendedor ambulante ou trabalhando na clandestinidade, com o "nome emprestado". Esta situação, segundo depoimentos registrados por Tucci Carneiro, só começou a mudar após $1950^{177}$.

Percebemos também que a CIP acompanhava a vida do beneficiado durante alguns meses e concedia novos empréstimos quando necessário, até mesmo antes do ressarcimento da quantia inicial. Por exemplo, anos mais tarde, em 1946, a situação de Adolf Schiller permanecia inalterada:

"Declara não estar em condições de pagar a mínima importância porque - como alega ganha pouco e tem parentes na Europa aos quais manda pacotes. Não promete nada a respeito de qualquer pagamento futuro" ${ }^{\text {"178 }}$.

A ajuda aos parentes e amigos na Europa também se tornou imprescindível no momento em que a guerra já havia terminado e milhares de judeus se encontravam sem destino, sem documentos e sem provimentos. A dívida de Schiller só começou a ser paga em 1947, quando o mesmo conseguiu um emprego numa fábrica de blusas. Importante lembrar que, em 1942, havia sido decretada uma lei que facultava aos empregadores "o direito de rescindir os contratos de trabalho com empregados estrangeiros, súditos das nações com as quais o Brasil haja rompido relações diplomáticas ou se encontre em estado de beligerância" ${ }^{\prime 79}$. Ou seja, considerando-se que, em muitos casos, os judeus eram confundidos com súditos eixistas por causa de sua nacionalidade alemã, podemos inferir que esse tenha sido um dos motivos pelos quais os judeus tiveram dificuldades em arranjar um emprego. Geralmente, os cargos ocupados pelos imigrantes ou refugiados judeus, eram conseguidos no interior da

\footnotetext{
${ }^{177}$ Maria Luiza Tucci Carneiro. Brasil, Um Refúgio nos Trópicos: A Trajetória dos Refugiados do Nazifascismo. São Paulo: Estação Liberdade, 1996.

${ }^{178}$ Pront. de Adolf Schiller. Secção de Serviço Social da Congregação Israelita Paulista; Casos atendidos - 1939 a 1946. Fundo 187/AHJB.

${ }^{179}$ Decreto-lei $n^{o} .4 .63831$ de agosto de 1942. Faculta a rescisão de contrato de trabalho com súditos das nações com as quais o Brasil rompeu relações diplomáticas ou se encontra em estado de beligerância e dá outras providências.
} 
própria comunidade, como, por exemplo, a Manufatura de Brinquedos Estrella que mantinha israelitas em seus quadros empregados ${ }^{180}$.

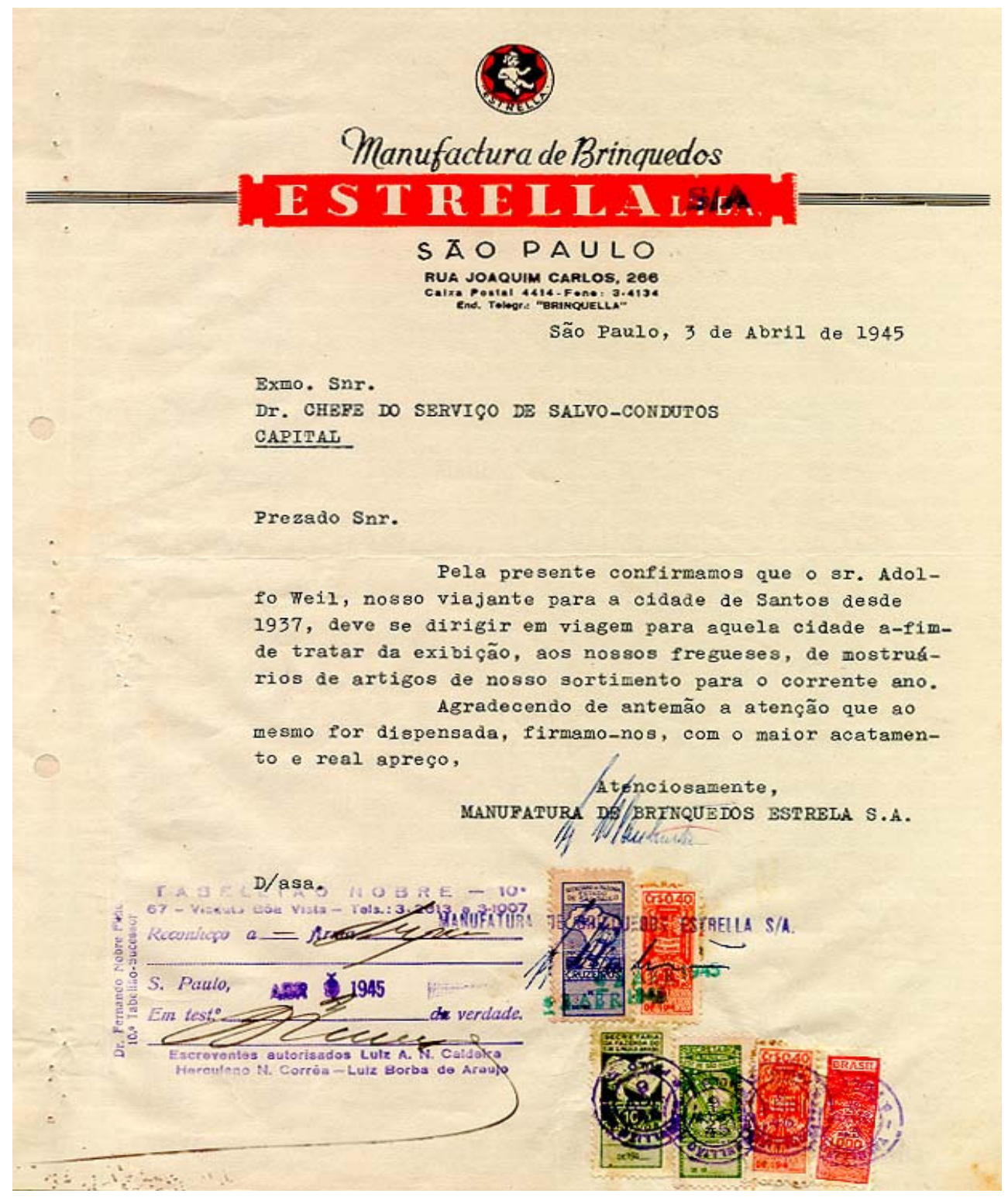

- Requerimento de Salvo-conduto da Manufatura de Brinquedos Estrella em nome de seu funcionário Adolfo Weill. Departamento Estadual de Ordem Política e Social. São Paulo, 3 de abril de 1945. Pront. $n^{o} .20403$ de Adolfo Weill. DEOPS/SP. APESP.

Dentre as prioridades da CIP estava o atendimento a comunidade judaica instalada no Brasil. Esses dispunham de serviços religiosos, reuniões culturais, ajuda médica e

${ }^{180}$ Entre os empregados da Estrella, citados em documentos do DEOPS, temos: Pront. $n^{\circ} 20403$, de Adolfo Weill; Pront. $n^{\circ} 20505$, de Herbert Cohn. DEOPS/SP. APESP. 
financeira, creche para as crianças e, até mesmo, uma colônia de férias. A falta de recursos era um problema recorrente para a CIP. A fim de incrementar a receita, os líderes organizavam festas, aumentavam as mensalidades e, em alguns casos, membros da Diretoria e da Assembléia dos Representantes ofereciam empréstimos, como o fez Ludwig Lorch em setembro de $1939^{181}$.

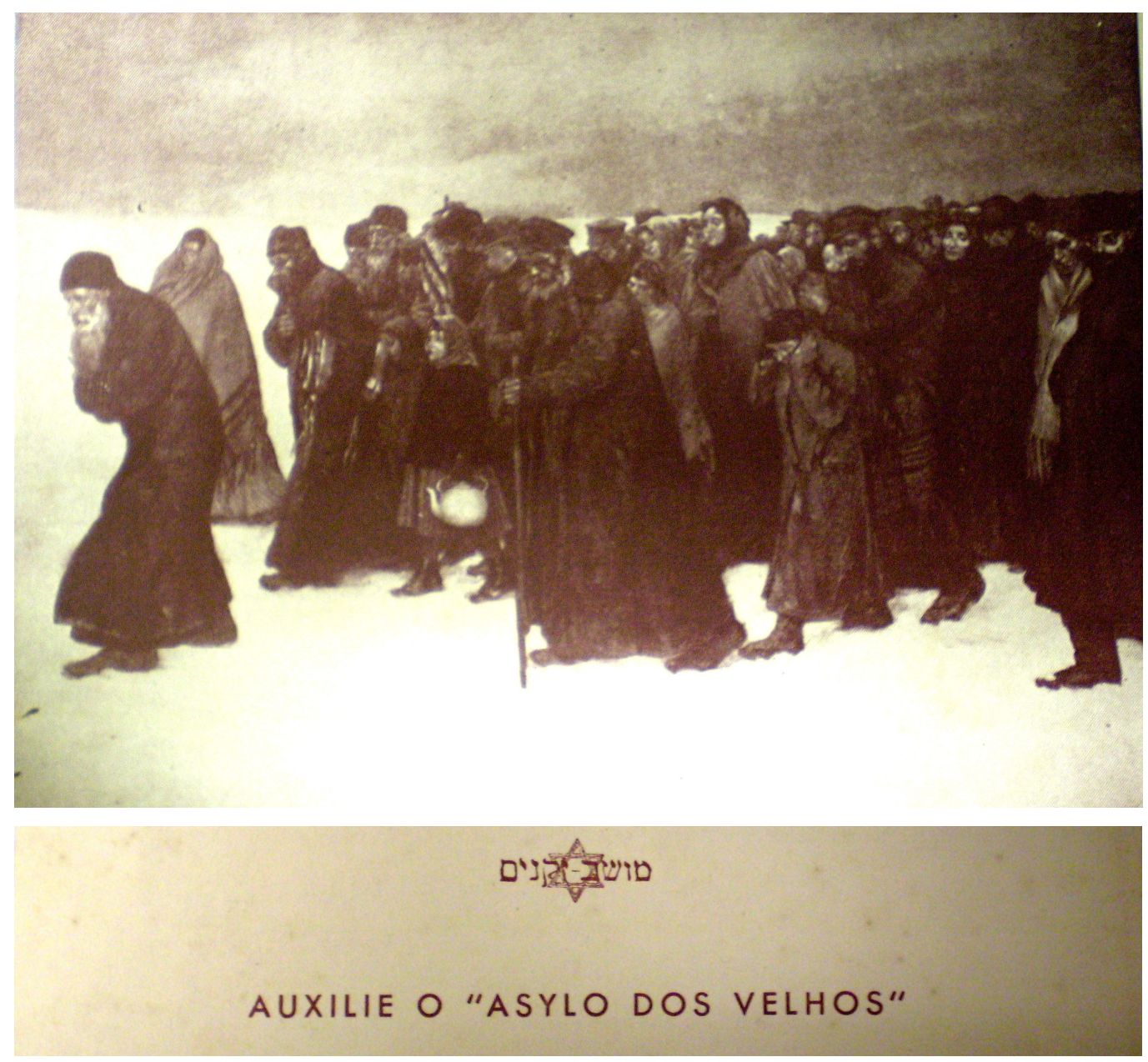

- Cartão de doação enviado pela CIP aos seus sócios e correligionários. São Paulo, 1938. Fundo Lorch /LEER - USP.

Entre o final do ano de 1937 e o início de 1938, a CIP decidiu organizar um lar para as pessoas mais velhas, uma espécie de asilo, no qual seriam aceitos todos e quaisquer judeus, independentemente de sua nacionalidade ${ }^{182}$. A fim de concretizar essa

\footnotetext{
181 Ata da Reunião da Assembléia dos Representantes da CIP. São Paulo, setembro de 1939. F.187/AHJB.

${ }^{182}$ Carta de José Mindlin para Ludwig Lorch, Presidente da Congregação Israelita Paulista. São Paulo, 25 de novembro de 1937. Fundo Lorch /LEER - USP.
} 
idéia, a Congregação iniciou uma campanha entre seus sócios para arrecadar o dinheiro necessário à compra de um terreno e à construção do Asilo. A propaganda preparada pela Congregação fazia alusão ao "judeu sem rumo", "errante', que caminha por terras inóspitas a procura de um lugar para se estabelecer. $\mathrm{Na}$ imagem, percebemos que os anciãos estão à frente desse grupo de pessoas, guiando-os, apesar do sofrimento e do frio aparentes. Procurava-se sensibilizar os possíveis doadores, fazendo-os lembrar das mazelas enfrentadas pelo povo judeu através da história. Infelizmente, não encontramos na documentação analisada indícios de que o Asilo tenha sido realmente construído.

O pedido de maiores contribuições por parte dos sócios exigia longas reuniões para discutir estratégias de angariação de fundos. Era preciso informar os sócios sobre as atividades da CIP, sua amplitude, nível de alcance e de emergência. As despesas com a compra do sítio João Dias, destinado para o lazer crianças e jovens consta como um dos principais motivos da falta de dinheiro registrada nos anos de 1942 e 1943 . No entanto, coube ao setor de Assistência Social a responsabilidade pelos déficits no orçamento, durante as duas primeiras décadas da Congregação. A recepção e o sustento dos imigrantes e refugiados recém-chegados eram itens emergenciais e que pesavam no orçamento das despesas. Nesse contexto, era enviado um relatório de gastos aos contribuintes e, em alguns momentos, os mesmos recebiam visitas de representantes da CIP, em suas casas, no sentido de esclarecer-lhes suas dúvidas. Em 1938, no combate à inadimplência, a Diretoria determinou que apenas aqueles que estivessem em dia com as suas mensalidades poderiam participar das reuniões na sinagoga ${ }^{183}$.

No ano de 1939, foram instaladas "caixinhas da CIP" nas residências dos associados, para que os mesmos fossem também responsáveis pela coleta de fundos para a Congregação. Anos mais tarde, em 1942 - momento em que a CIP tornou-se muito procurada devido às vantagens que oferecia aos seus sócios - determinou-se que, os judeus que viviam no Brasil há mais de um ano e meio, e que somente naquele instante estavam pedindo sua filiação à Congregação, deveriam pagar uma multa correspondente ao valor de doze mensalidades ${ }^{184}$.

Não obstante a compreensão dos associados, a cada dois anos era necessária a realização de campanhas maiores na CIP ou "drives unidos", com outras associações, na tentativa de arrecadar maiores valores. Nesses drives, a comunidade judaica de São

${ }^{183}$ Ata da Reunião do Conselho das Comissões da CIP. São Paulo, 1 de agosto de 1938. Fundo 187/AHJB.

${ }^{184}$ Ata da Reunião do Conselho das Comissões da CIP. São Paulo, 30 de setembro de 1942. Fundo 187/AHJB. 
Paulo era chamada a participar e, ao final da campanha, os recursos arrecadados eram divididos entre as várias associações participantes.

\section{2 - As Crianças e os Jovens da Congregação Israelita}

Mais de $1 / 4$ das despesas da CIP destinavam-se à formação dos jovens e das crianças. Seus dirigentes preocupavam-se com a formação educacional, física e religiosa daqueles que seriam o futuro da comunidade judaica no Brasil. A própria sede da associação possuía um espaço reservado para os jovens, onde podiam estudar a torah, programar seu futuro profissional, conhecer amigos e entender o funcionamento de uma congregação. Em relação às crianças, muitas vezes órfãs, era necessário oferecer aprendizado, acolhida e lazer. A elas a CIP proporcionou educação durante o ano e repouso no período de férias.

Em sua primeira década de funcionamento, a CIP recebeu dezenas de casais que haviam imigrado para o Brasil sem nenhum recurso. Nesse contexto, tanto o homem quanto a mulher eram obrigados a trabalhar, ainda que possuíssem filhos pequenos. $\mathrm{O}$ fato de serem poucos os ambientes que pudessem acolher estas crianças levou a Diretoria da CIP a alugar, ainda em 1937, um casarão na Rua Barão de Piracicaba, no centro de São Paulo, destinado a ser o Lar da Criança Israelita. Esperava-se que a ajuda dada aos pais, no sentido de alcançar uma boa situação econômica, possibilitasse aos mesmos retirar seus filhos do Lar o quanto antes, cedendo seu lugar às crianças recémchegadas da Europa. No entanto, segundo Alfred Hirschberg, em muitos casos, a criança perdia um dos pais e o parente sobrevivente via-se obrigado a deixar seus filhos no Lar. Por isso, o Lar agia também, em alguns casos, como um substituto da família, mantendo cerca de quinze a vinte crianças em regime de internato ${ }^{185}$. A maioria das crianças internas permanecia no Lar até os quatorze anos, no caso dos meninos, ou até completar a maioridade, no caso das meninas. Foram muitos os casos de internos que, ao sairem do Lar, já possuíam profissão e moradia próprias. Os depoimentos de dois antigos alunos do Lar nos possibilitam entender melhor em que condições muitas crianças chegavam àquela instituição:

${ }^{185}$ Crônica Israelita 10 anos, Op. cit. Fundo 187/AHJB. 
"É difícil divertir uma criança órfã, fazendo-a esquecer o que sucedeu a seus pais. É ainda mais difícil educar uma criança, que passou jogada nas calçadas sujas das ruas..."186

(...) "Somos em quatro irmãos, quando atingi a idade de sete anos, minha mãe adoeceu gravemente e foi para o hospital(...) papai não tinha ninguém que quisesse tomar o encargo de cuidar de nós(...) teve pois de recorrer à Congregação, que lhe indicou o Lar das Crianças..." 187

As crianças que freqüentavam a instituição eram obrigatoriamente matriculadas em escolas de ensino público ou judaico. Subtraindo-se à responsabilidade de uma simples creche, o Lar oferecia às crianças aulas de português, de religião e tradição judaicas, noções de higiene, e ainda exames clínicos semestrais, de laboratório e dentários (realizados duas vezes ao ano), além do apoio psicológico. Partilhando da mesma filosofia da CIP, os responsáveis pelo Lar acreditavam que o ensino às crianças deveria contemplar também, aspectos da cultura e da identidade brasileiras, país no qual aquelas crianças cresceriam, trabalhariam e construiriam suas vidas futuras. Não obstante, a legislação brasileira corrente no Estado Novo exigia constantes demonstrações de nacionalismo por parte, principalmente, das instituições compostas por estrangeiros, além da presença de uma foto de Getúlio Vargas em todos os estabelecimentos voltados ao público. Nas fotografias expostas abaixo podemos observar o mapa do Brasil presente, até mesmo, durante o lanche das crianças; assim como o retrato do Presidente Vargas zelando por todos enquanto aprendem.

Apesar de ser parte da Congregação, a diretoria do Lar possuía autonomia para a contratação de pessoal, gestão financeira e orientação pedagógica. No controle da instituição havia um casal residente na sede do Lar, uma comissão administrativa responsável pelos aspectos financeiros e pela manutenção da casa - e uma comissão técnica, aos quais cabia a orientação pedagógica e social do Lar. Rapidamente, percebeu-se que a infra-estrutura da casa da Barão de Piracicaba era insuficiente para receber o fluxo de crianças que o momento exigia. Em relatório confidencial de Charlotte Hamburger ${ }^{188}$ à Diretoria da CIP, em 1943, constitui alvos de reclamação, a inadequação das instalações sanitárias, a inexistência de um quarto isolado que pudesse receber as crianças enfermas, assim como a falta de aposentos para a governanta do Lar. Naquele ano, o Lar dava assistência para 69 crianças matriculadas, mantendo cerca de

\footnotetext{
${ }^{186}$ Depoimento anônimo. Crônica Israelita 10 anos, Op. cit. Fundo 187/AHJB.

${ }^{187}$ Sigrid Irene Hornblas, na época com 15 anos. Crônica Israelita 10 anos, Op. cit. Fundo. 187/AHJB.

${ }^{188}$ Charlotte Hamburger, esposa de Hans Hamburger, um dos diretores da CIP, figurava como uma das diretoras do Lar da Criança Israelita.
} 
dezoito delas em regime de internato. Interessante ressaltar que, dessas dezoito crianças, três não eram de origem israelita.
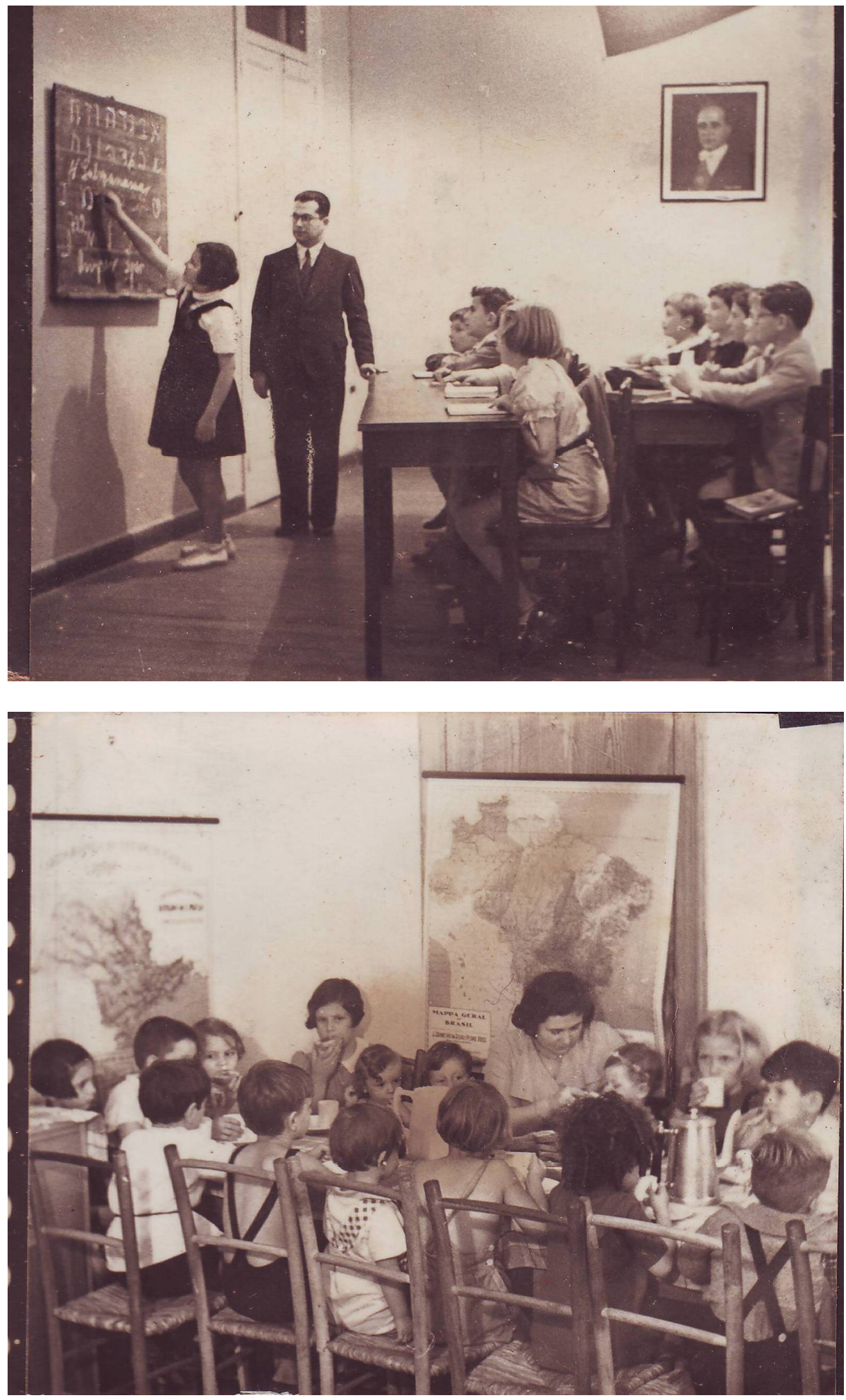

- Fotografias das crianças do Lar da Criança Israelita. São Paulo, s/d. Fundo Lorch/LEER-USP. 
Em 1945, a CIP realizou a grande "Campanha da Boa Vontade", que destinou um terço da quantia arrecadada para o JOINT, um terço para a Palestina e um terço para sua própria assistência social. Cumpridas as promessas feitas aos contribuintes, com as dívidas pagas, a Congregação resolveu reservar o dinheiro restante à compra de um terreno para a futura construção de um novo Lar das Crianças. Este se localizava no Alto da Boa Vista, em Santo Amaro. A pedra fundamental foi colocada dois anos mais tarde, em 1947, mas, devido à falta de recursos, a obra ficou parada durante doze meses.

A ameaça de despejo do Lar, com sede no casarão na Rua Barão de Piracicaba, em 1948, exigiu uma solução mais rápida para o problema financeiro. Foi constituída uma comissão que decidiu tomar um empréstimo de 300 mil cruzeiros; instituir o "mês do Lar", com festas e chás beneficentes em residências particulares; além de dobrar as mensalidades dos sócios da CIP enquanto a construção não acabasse. As propostas foram aceitas e, em 3 de julho de 1949, foi inaugurada a nova sede do Lar das Crianças, no bairro do Alto da Boas Vista ${ }^{189}$. Nesse momento, como o número médio de crianças internadas subira de 18 para 50, foram necessárias novas doações de lençóis, roupas de banho, móveis, camas, etc.

Não obstante a atuação do Lar Israelita, tornou-se claro que, em alguns casos, os danos psíquicos e físicos sofridos pelas crianças não seriam remediados somente com educação e cuidados. Era necessário distrair a criança, retirá-la de um lar com problemas e proporcionar a ela semanas de repouso e lazer.

"Conhecemos entre essas crianças certo número de mal nutridas devido aos poucos recursos dos pais; outras bem pálidas embora não estejam doentes (...). Outras crianças vivem num ambiente de tal nervosismo, que a mãe sem saber dominar lhes aplica às vezes castigos tão severos que o resultado logo mais lhe causa remorso."190

A situação das crianças judias no Brasil no inicio da década de 1940 pode ser entendida como reflexo do estado de desespero no qual se encontravam seus pais. Muitas eram partes de famílias de refugiados que haviam deixado para trás uma vida completamente diferente: parentes, amigos, emprego, casa e poupança. Não encontravam, pois, nenhum tipo de sustentação psicológica em suas casas e, em muitos casos, acabavam adoecendo sem nenhum motivo aparente. Segundo a lógica dos

\footnotetext{
${ }^{189}$ Alice Irene Hirschberg. Op.cit.

${ }^{190}$ Carta de Betti Katzenstein, Representante da Comissão da Colônia de Férias da Congregação Israelita Paulista para a Diretoria da Congregação Israelita Paulista. São Paulo, 2 de dezembro de 1940. Fundo Lorch /LEER - USP.
} 
dirigentes da CIP, era tarefa da colônia judaica contribuir para a formação de uma juventude sadia que pudesse prosseguir com sua obra comunitária. Assim, durante as férias de 1940/41, a Congregação iniciou o funcionamento de sua Colônia de Férias.

A Colônia atendia a quaisquer crianças judias indicadas pela OFIDAS, pela Associação dos Israelitas Poloneses ou pelo Lar da Criança. Constituía uma grande oportunidade para que as crianças judias convivessem com seus iguais em ambiente judaico, participando de cultos, orações e alimentando-se de forma kusher. Os meninos deveriam ter entre 7 e 13 anos de idade, e as meninas entre 7 e 14 anos.Como a procura era grande, foram impostos critérios baseados nas necessidades físicas e sociais que ajudavam a selecionar os beneficiados. Os pareceres eram dados por dois médicos sob os nomes de Dr. Petraglia e Dr. Machado.

As primeiras colônias situavam-se em São Carlos, no Estado de São Paulo, em uma fazenda alugada chamada Embaré ${ }^{191}$. Os custos da estadia das crianças na colônia de férias deveriam ser quitados, quando possível, pela sua própria família, à vista ou em prestações mensais. No entanto, muitas crianças ou eram órfãs, ou não possuíam pais em condições de pagar por suas férias. Nesse caso, os membros da comunidade judaicopaulistana eram chamados a contribuir, a adotar aquelas crianças durante as quatro semanas de lazer:

“(...) 100-150 crianças israelitas, muitas entre elas mal alimentadas, exhaustas e que urgentemente precisam de férias, de sol, luz, alegria e de boa comida, devem ser mandadas à colônia de férias dentro de poucas semanas (...). Neste ano peço a todos que tem sentimento e possibilidade que cooperem com a colônia de férias (...). Pague o senhor, a senhora, a moça e o moço para um dia (7cruzeiros) uma semana ou para toda a estadia de uma criança na colônia de férias! Qualquer que seja a ajuda, nós teremos satisfação de saber: "uma criança israelita é lá feliz e recuperando saúde porque eu ajudei". ${ }^{192}$

Os pedidos de ajuda eram prontamente atendidos, tanto que, para as férias de 1942/43, o dinheiro arrecadado foi $25 \%$ maior do que os gastos incorridos. Ao final dessa temporada, a Congregação comemorava o sucesso da empreitada: várias crianças haviam sido curadas de problemas respiratórios; outras estavam visivelmente mais

\footnotetext{
${ }^{191}$ Alice Hirene Hirschberg afirma em Desafio e Resposta, que a fazenda Embaré havia sido utilizada apenas durante o período de 1940/41. No entanto, em relatório assinado por Alberto Stahl, Presidente da Comissão da Colônia de Férias da Congregação Israelita Paulista, em março de 1943, admite-se que, ainda nesse ano, a estadia das crianças durante as férias aconteceu em Embaré.

${ }^{192}$ Rascunho de nota a ser publicada no $\mathrm{n}^{\circ} .101$ do jornal Crônica Israelita. Escrito por Ludwig Lorch. s/d, 1942. Fundo Lorch /LEER - USP.
} 
felizes. Entre aquelas que sofriam de má-alimentação, algumas haviam engordado mais de um quilo. ${ }^{193}$

Os altos custos do aluguel de uma propriedade associado ao sucesso da Colônia de Férias na recuperação de várias crianças, levaram a CIP no inicio de 1944, a comprar o sítio João Dias, nos arredores de Jundiaí. Visando a reposição do dinheiro gasto com a compra e a geração de novos recursos destinados à reforma, uma parte do sitio abrigava uma plantação de eucaliptos. No entanto, até 1946, esse local não havia sido utilizado pelas crianças devido à precária situação em que se encontravam suas instalações. Esse fato, entendido por muitos como uma atitude displicente por parte dos Diretores da CIP, levou a comissão responsável pela Colônia a pedir demissão e gerou a discussão sobre a venda de uma parte do sítio. Devido a esses e outros problemas, em 1948 teria lugar a última Colônia de Férias ${ }^{194}$.

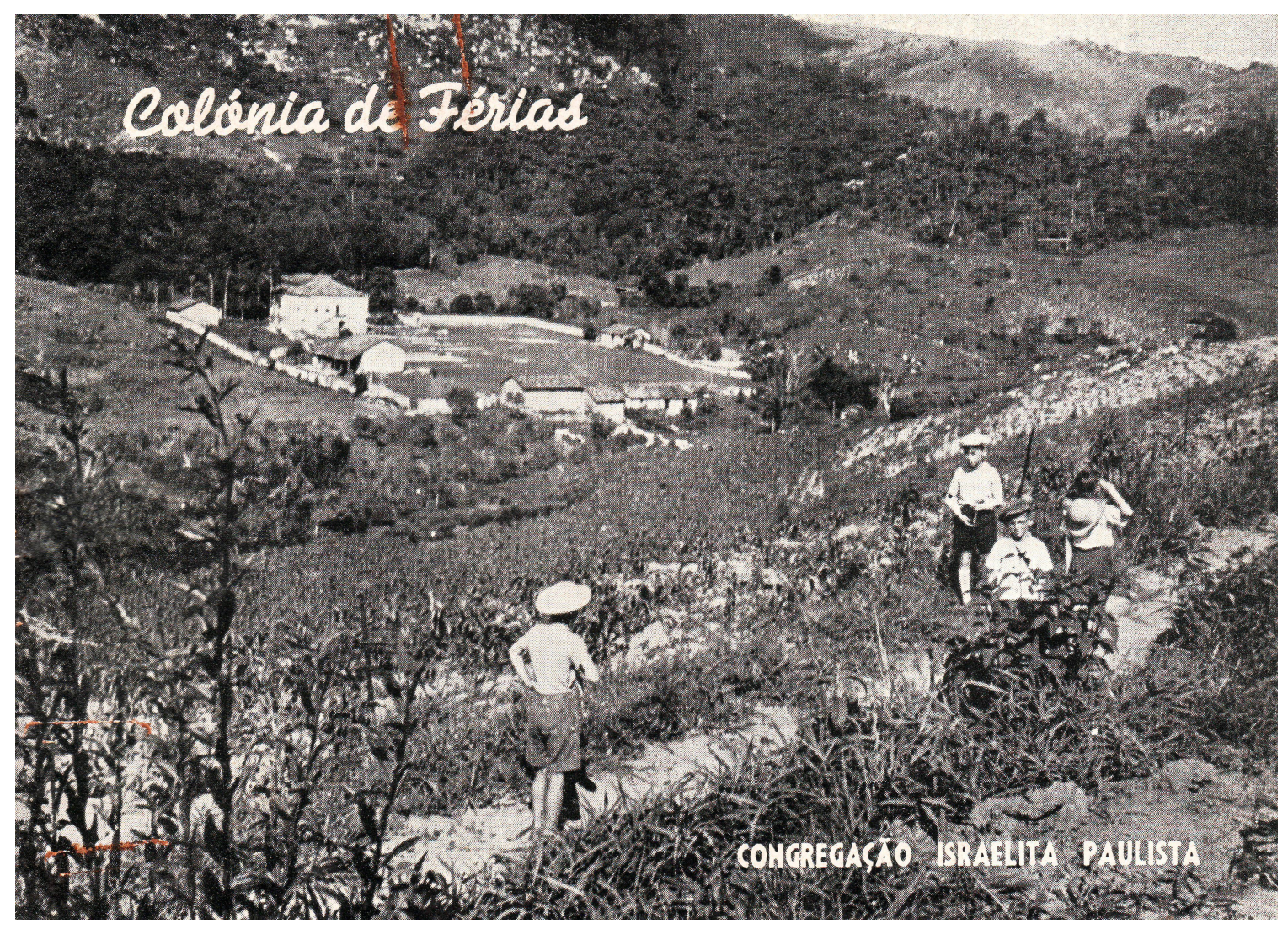

- Fazenda Embaré. Propaganda da Colônia de Férias para arrecadação de fundos das férias de 1942/1943. São Paulo, 1942. Fundo Lorch /LEER - USP.

\footnotetext{
193 Relatório da Comissão da Colônia de Férias da Congregação Israelita Paulista para o período de 1942/43. São Paulo, 22 de março de 1943. Fundo Lorch /LEER - USP.

${ }^{194}$ Alice Hirene Hirschberg. Op.cit. p. 209.
} 


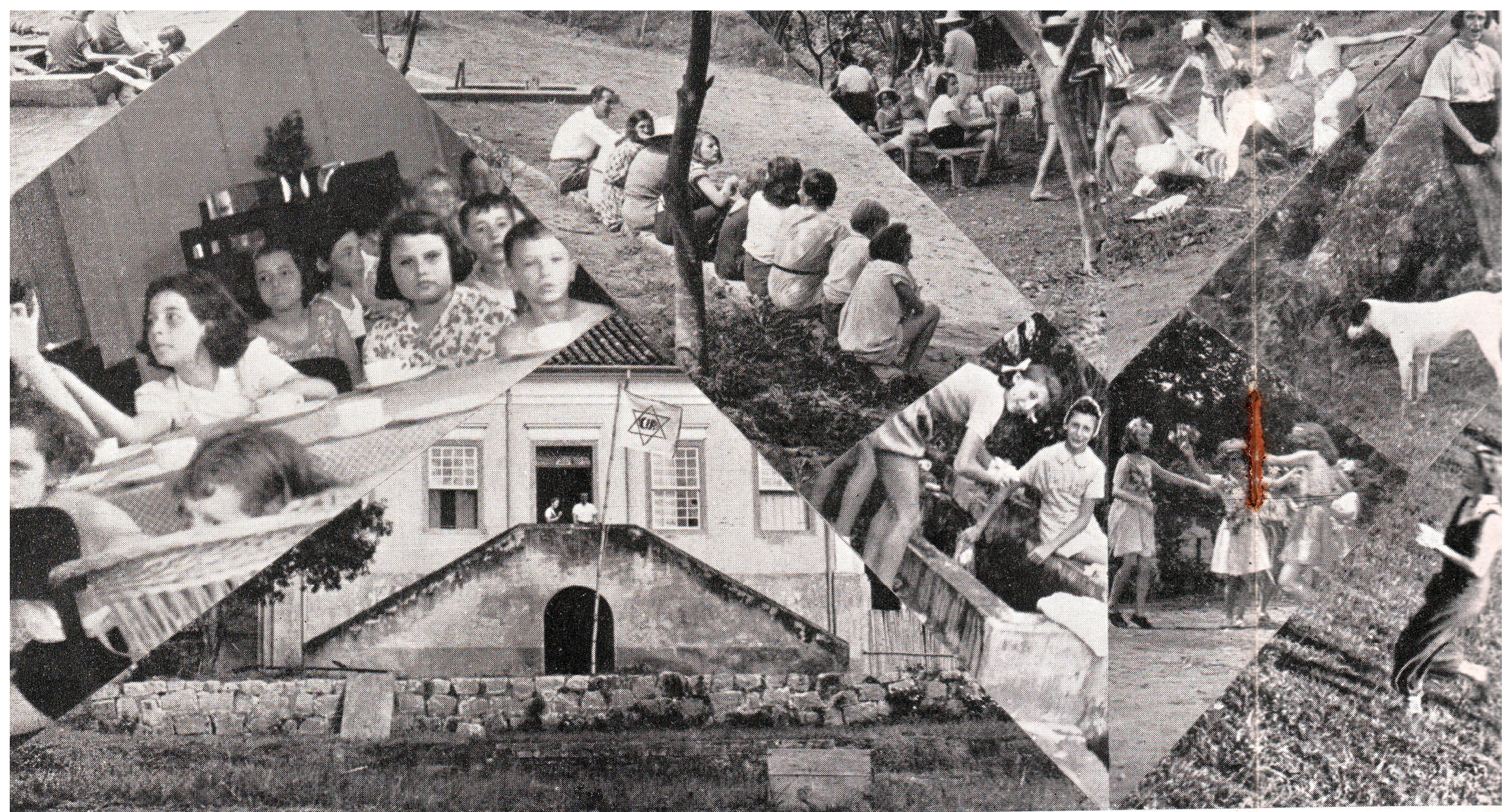

Músicas, canções e risos de contentamento que já de longe se podem ouvir, provam a felicidade e alegria que nossa juventude sente de férias.

- Montagem cm fotografias das crianças na Colônia de Férias de Embaré. Congregação Israelita Paulista. São Paulo, 1942. Fundo Lorch/LEER - USP. 
O Lar da Criança Israelita e a Colônia de Férias eram instituições voltadas preferencialmente às crianças até, em média, os 14 anos de idade. Por outro lado, segundo os estatutos da CIP, para que o individuo pudesse participar ativamente da Congregação, tornando-se sócio, era necessário ter idade superior a 21 anos. Esse intervalo de tempo na vida dos jovens judeus, entre a infância e a maioridade tornar-seia uma das grandes preocupações da CIP alguns anos após o inicio de suas atividades. Inicialmente, era necessário garantir que a Congregação sobreviveria ao futuro, que teria uma diretoria interessada em continuar com suas obras social e religiosa e sócios dispostos a contribuir mensalmente com a associação. Além disso, era preciso manter vivos os costumes e as tradições judaicas, e criar um ambiente no qual os jovens pudessem conviver com outros judeus. Mas, como resolver essas questões numa época em que novos refugiados chegavam a cada dia e tantos ainda não haviam sido radicados?

Em reunião da assembléia dos representantes, em1939, esses problemas vieram à tona. Alguns dos diretores da CIP defendiam que os jovens deveriam passar esses anos em contato com a juventude brasileira, freqüentando clubes brasileiros, enquanto outros acreditavam que essa atitude serviria como caminho para a dissolução do judaísmo. Segundo o Dr. Ludwig Lorch:

\begin{abstract}
“A juventude não se deve separar do mundo exterior e o nosso caminho não pode ser o de crearmos uma Congregação alemã-judia. Mas também não é muito fácil encontrar o contato com os brasileiros. Para cada ser humano é importante o alívio de poder conversar com companheiros do infortúnio e existem muitos jovens que estão passando muito mal do ponto de vista psicológico, sendo que aqueles certamente não encontrariam alívio si entrassem num Clube brasileiro". ${ }^{195}$
\end{abstract}

Segundo o Presidente da Congregação, cabia aos judeus tomar conta de seu próprio destino, mas, sem se esquecerem de que havia sido o Brasil que os tinha acolhido, e que, por esse motivo, podiam viver em um país no qual não existiam guerras. Assim, deveriam se esforçar para aprender novos costumes, respeitar a legislação vigente e compreender a mentalidade dos brasileiros. Por outro lado, os judeus continuavam a possuir um passado comum, com tradições comuns e uma religião própria que não deveriam ser esquecidos. A juventude deveria então, ser preparada para transitar com sucesso entre os mundos judeu e brasileiro.

\footnotetext{
195 Ata da Assembléia dos Representantes da Congregação Israelita Paulista. Sã Paulo, 6 de setembro de 1939. Fundo 187/AHJB.
} 
Decide-se então contratar professores visando atender a juventude de 10 a 20 anos de idade. Foi nesse momento, entre o final do ano de 1939 e o inicio de 1940, que a CIP trouxe de Rolândia o casal Wilhelm e Anita Speyer, ambos alemães refugiados saídos de Berlim e radicados no Brasil desde 1937. Segundo Alice Hirschberg, esse casal de educadores eram oriundos do mesmo ambiente cultural e social de que provinha a maioria dos sócios da CIP, a Alemanha. Logo, conseguiram incorporar e reunir grande parte dos jovens "dando-lhes orientação cultural judaica sistemática, inclusive iniciação religiosa." 196 Em convergência com a opinião expressa por Ludwig Lorch, Wilhelm e Anita Speyer acreditavam na necessidade de introduzir a juventude judaica na convivência brasileira, através do conhecimento da língua portuguesa e da leitura de suas principais obras. Sob outro aspecto, era preciso também organizar esses jovens “(...) tanto o interesse da Congregação como também no interesse dos judeus em sua totalidade". 197

Diante desta realidade, a CIP inaugurou, em março de 1941, a Casa da Juventude com sede na Rua Augusta, separada dos escritórios da CIP. Neste espaço eram organizadas as atividades esportivas e religiosas das quais os jovens participavam, além de saraus de dança e música, montagem de peças teatrais e estudo das tradições e dos preceitos judaicos. Em novembro, o casal Speyer e a Diretoria da Congregação discutiam sobre a possibilidade de expandir a Casa da Juventude, transformando-a num "Abrigo" ou "Internato de Mocinhos", destinado a atender a população judaica radicada nos bairros vizinhos. ${ }^{198}$

$\mathrm{O}$ atendimento aos jovens concentrou-se na apresentação de todos os aspectos do judaísmo, sem impor a necessidade de presença na sinagoga ou a escolha de alguma corrente religiosa especifica. A Palestina também era estudada, mas, sem que houvesse qualquer aspecto de propaganda sionista. Ensinava-se um pouco de hebraico e a história do povo judeu, desde a época bíblica até a atual situação na Palestina. Os Speyer procuravam, dessa forma, criar um grupo de homens que estivessem preparados para aceitar a responsabilidade que a comunidade judaica exigia. Pregavam que os jovens deviam ser leais ao Brasil enquanto cidadãos, sem esquecer-se de suas verdadeiras origens culturais e históricas.

\footnotetext{
${ }^{196}$ Alice Irene Hirschberg. Op.cit. p. 104.

${ }^{197}$ Protocolo da Sessão da Assembléia dos Representantes da Congregação Israelita Paulista. São Paulo, 12 de novembro de 1939. Fundo 187/AHJB.

${ }_{198}$ Parecer da Comissão da Juventude da Congregação Israelita Paulista, Departamento Juvenil, sobre a ampliação da Casa da Juventude. São Paulo, 11 de novembro de 1941. Fundo Lorch /LEER - USP.
} 
"O trabalho era efetuado em quatro círculos concêntricos. (...) O círculo externo compreendia as realizações sociais, divididas por grupos etários, sendo condição única de participação a inscrição prévia (...). O segundo círculo compreendia cursos sobre qualquer tema, que reunisse pelo menos quatro interessados com a obrigação de frequiência regular. $\mathrm{O}$ terceiro era constituído pelos grupos escoteiros (masculinos e femininos), e por último, o círculo dos dirigentes - os diretores e os chefes escoteiros. , 199

A CIP tinha como preocupação da Congregação não só a arregimentação dos jovens, mas também o seu futuro profissional. Em 1942, a Diretoria da associação discutiu a possibilidade de patrocinar meios de formação profissional para jovens, entre 11 e 14 anos, em condições economicamente desfavoráveis, que já tivessem conseguido o diploma escolar, mas não possuíssem idade suficiente para ingressar no mundo do trabalho. Essa atitude justificava-se frente ao fato de esses jovens serem filhos de imigrantes de primeira geração, geralmente pobres e que precisavam de garantias profissionais para, no futuro, ajudar seus pais a superar as dificuldades impostas pela situação econômica do país.

As possíveis vertentes profissionais a serem seguidas pelos adolescentes eram, basicamente, três: as manuais, as liberais e as comerciais. Considerava-se até mesmo, a possibilidade de ajudar aos pais menos favorecidos efetuando parte do pagamento de escolas renomadas como o Mackenzie College, a Associação Cristã dos Moços ou a Escola Álvares Penteado. Todavia, a escassez de recursos por parte tanto da Congregação como dos pais dos jovens, provocou a concentração dos interessados em cursos mais baratos e de menor duração, como datilografia, taquigrafia, português, caligrafia e cálculo comercial. Além da matrícula em escolas especializadas, os jovens tinham acesso também a aulas de língua inglesa e cultura geral, ambas ministradas na própria Casa da Juventude. $^{200}$

Em novembro de 1942, como conseqüência de uma denúncia anônima, um investigador do Departamento de Ordem Política e Social dirigiu-se até a Casa da Juventude a fim de obter informações a respeito de seu funcionamento e de suas atividades. Foi atendido por Wilhelm Speyer que respondeu a todas as suas perguntas. No dia seguinte, o mesmo investigador compareceu à sede da CIP para confirmar a veracidade das informações dadas por Speyer. Satisfeito, declarou que a situação da Casa da Juventude era legal e que o "assunto policial" estava resolvido. Provavelmente,

\footnotetext{
${ }^{199}$ Carta de Wilhelm Speyer para Alice I. Hirschberg. Alice Irene Hirschberg, Op. cit, p. 106.

${ }^{200}$ Relatório de Betti Katzenstein: "Sugestão para a Comissão dos Três". São Paulo, 19 de janeiro de 1942. Fundo Lorch /LEER - USP.
} 
a suspeita pairava sobre possíveis reuniões comunistas que, segundo a lógica policial, ocorriam nos meio judaicos ${ }^{201}$.

Apesar da função estritamente beneficente, o Lar da Criança Israelita também não escapou às investidas policiais. Segundo o rabino Fritz Pinkuss, as autoridades do Estado Novo tentaram identificar os judeus com os comunistas, suspeita que ocasionou inúmeras invasões não só na sede da sociedade, mas também no Lar das Crianças ${ }^{202}$. A idéia de que o perigo comunista estava intrincado no seio da população brasileira induzia alguns civis a delatar os judeus enviando cartas à Polícia Política. A carta transcrita abaixo foi escrita pela dona de casa Lucy Bley, brasileira, vizinha da sede do Lar da Criança Israelita:

\begin{abstract}
"Informações obtidas em torno do edifício nº 670 da Rua Barão de Piracicaba nesta capital:

A casa acima mencionada é visitada freqüentemente por pessoas de ambos os sexos, pessoas essas de aparências suspeitas. Trata-se em maior número russos, alemães, japonezes e pretos (destes últimos pude constatar que dois falam perfeitamente o russo (dialecto). A entrada é sempre levada à effeito apóz haverem sido trocados signaes convencionaez; presenciei por diversas vezes que o signal mais usado é tocar a testa com a mão direita e logo em seguida leva-la ao ombro esquerdo.

Intitulando-me funcionária da Prefeitura, lá estive, informaram-me ser lá um asylo pra creanças allemãs (creanças anormais). Depois de muita insistência disseram-se ser diretora do referido asylo Fran Hamburger; porém estas informações discordam de outras por mim levadas a effeito.

$\mathrm{Na}$ Cia. Light está registrado como "Congregação Israelita". Obtive o número telefônico e por diversas vezes para lá liguei, procurei fallar em alemão e sempre obtive respostas evasivas - o phone é 5-7117.

A casa "Tókio" forneceu alguns móveis próprios para consultório ou laboratório. A gerente dessa casa não quis entrar em maiores detalhes, a não ser que os móveis foram comprados em nome de Dra. Elza. Estou certa de que na casa "Tókio" poderia ser obtido melhores informações, porém no dia era impossível insistir. Quis falar ao chauffer do caminhão que fez a entrega dos móveis, nisto fui impedida pela gerente da casa.

Freqüentemente visita a dita residência o carro número P. 1375, chapa de médico, carro azul escuro o proprietário (procurei no livro vermelho) é o Sr. A. C. Riching, residente a rua Canadá 28. Ainda uma tarde tive a ocasião de presenciar a chegada deste cavalheiro acompanhado de outro senhor e duas senhoras. Apóz desembarcarem e depois de 'terem livre entrada' o chauffer do carro, que é preto e gordo, retirou do interior do carro inúmeros cobertores de lã e mantilhas levando tudo para dentro da casa 670.

Também é visto com freqüência o carro número 9944 de propriedade de Geraldo Russo residente à rua Martiniano Prado, número 1. Este carro geralmente tem permissão de entrar no pátio da casa porém, entra e sai com capotas decaídas.

Existem na casa cerca de seis a sette creanças que brincam sempre numa área ao lado,parecendo que são obrigadas a tal simplesmente para confirmar a lenda de asylo. Estas creanças porém são fortes nada tendo de 'anormaes'. Trata-se mesmo que ao
\end{abstract}

\footnotetext{
${ }^{201}$ Taciana Wiazovski, O Mito do Complô Judaico-Comunista no Pensamento Autoritário Brasileiro: Gênese, Difusão e Desdobramentos, Op.cit.

${ }^{202}$ Fritz Pinkuss, Op.cit.
} 
mostrarem desejo de sair da referida área, pra lá são levadas novamente por uma senhora gorda, typo de mulher judia.

Anota característica de tudo é que na maior parte das vezes as pessoas que lá entram ao sahirem trazem outro traje, completamente diferente do que entraram. Aos homens é freqüente a mudança de camisas e gravatas.

Parece-me que estão levando a effeito alguma construção no prédio ou na garagem do mesmo.

Nestes últimos dias tem estado lá o carro número 60-29 do Sr. Adib Pecho Gureidini, residente à rua Itaby número 22 . Também tem sido notado um carro completamente fechado (typo caminhão de padaria) este é azul e o chauffer um preto, quando lá chega retira do interior uma enorme cesta porém esta entra e sahi cheia da mesma forma, dando a perceber que si entra com uns artigos ou objectos, de lá sahi com outros.

No porão da casa existe um móvel de forma de geladeira, é escuro com diversas chaves de contato amarellas, dá impressão de ser estação emissora de rádio.

Procurei no livro telephonico si existia o nome Hamburger e só encontrei Dr. Hans Hamburger rua Haddoch Lobo, 1625, phone 8-2972.

Ao acontecimentos acima mencionados têêm sido notados também por pessoas que rezidem ao prédio fronteiro e no qual rezide o Snr. Dr. Ariovaldo do Amaral.

Procurarei maiores informações e assim que obtiver darei sciência aos meus superiores. Lucy Bley.",203

Este documento nos remete ao imaginário político da coletividade brasileira dessa época que, influenciado pela propaganda oficial, se fazia povoado por perigos reais e imaginários. Elizabeth Cancelli explicita que, durante todo o período da era Vargas, o governo conseguira fazer, através de seus múltiplos instrumentos de propaganda, com que grande parte da população se sentisse engajada nas campanhas cívicas para a construção de um novo país. "A delação foi uma forma de engajamento participativo muito estimulada pelas autoridades" ${ }^{204}$. Segundo a autora, nestas denúncias havia uma forte vontade de ser útil e de contribuir de alguma forma e, num momento no qual o comunismo representava uma forte ameaça, as manifestações individuais de cidadãos que se colocavam no papel de "atentos delegados ideológicos do Estado" ${ }^{205}$ eram fortalecidas. Nesse contexto, Lucy Bley sentindo-se útil à nação, procurou recolher o maior número de informações possível.

Em decorrência dessa delação, o Lar das Crianças foi investigado por anos seguidos. Após receber esta carta, a Polícia Política tomou as primeiras providências: destacou investigador para ir ao local e recolher informações complementares. Em 5 de novembro de 1937, Albuquerque Martins relatou ao Delegado de Ordem Social, que estava procedendo a investigação em torno do referido prédio, conseguindo apurar que, há dois meses, moravam ali um casal de judeus em companhia de uma moça e de uma

\footnotetext{
${ }^{203}$ Carta de delação de Lucy Bley para o Departamento de Ordem Política e Social. S/d. Pront. $n^{\circ} 4705$, da Congregação Israelita Paulista. DEOPS/SP. APESP.

${ }^{204}$ Elizabeth Cancelli. O Mundo da Violência. A Polícia da Era Vargas. Brasília: UnB, 1994, p. 93.

${ }^{205}$ Ibid. p. 95.
} 
empregada, e que vinham sendo alvo de comentários por parte da vizinhança, devido à sua discrição e ao fato de não falarem com ninguém. Pela manhã eram levadas ao prédio inúmeras crianças que permaneciam ali até à tarde. $\mathrm{O}$ investigador acrescentou que no interior do prédio não se notava nada de estranho, a não ser uma parte de um compartimento ocultado por um pano. Notou que durante o dia, entravam muitos indivíduos sobraçando pastas volumosas e, saindo nas mesmas condições. Nas palavras do investigador: “(...) não vi fazerem sinal, parecendo que alli só entram pessoas conhecidas da casa, não havendo senha portanto" ${ }^{206}$.

Alceu notou a existência de um aparelho de rádio receptor e de uma boa antena no telhado e, a respeito da curiosidade da vizinhança, acrescentou:

"Dado à cumplicidade do caso, em se tratando de judeus, gente bastante inteligente, sagazes ao extremo, o único modo de apurar devidamente a denúncia, seria levar a efeito um cerco em regra a esse prédio e, realizar em seguida uma busca rigorosa alli" ${ }^{\prime 207}$.

Nesse trecho, em específico, percebemos características inerentes do discurso anti-semita: o investigador poderia até não constatar o fundamento da acusação feita por Lucy Bley, mas, como se tratavam de judeus, lhe pareceu óbvio que, por trás daquela imagem de tranqüilidade, se escondiam atividades subversivas. Segundo Taciana Wiazovski, "o fato de um indivíduo ser judeu ou simplesmente de origem judaica interferia negativamente enquanto critério de julgamento da Polícia Política brasileira" ${ }^{208}$.

No dia seguinte a esse informe, Alceu de Albuquerque Martins, enviou outro relatório ao Delegado de Ordem Social acrescentando que Luíza Lorch, inquilina do prédio em questão, havia realizado recentemente, diversas compras de móveis nas casas Tókio, tendo o cuidado de listar os itens adquiridos para o Lar das Crianças. Ocorreu ao investigador o nome de um médico, também judeu, Ludwig Lorch, por causa do sobrenome em comum com Luíza ${ }^{209}$. Tendo voltado ao mencionado prédio, Alceu

\footnotetext{
${ }^{206}$ Relatório de Investigação de Alceu de Albuquerque Martins, Inspetor $n^{\circ} 228$, ao Delegado de Ordem Social. Superintendência de Ordem Política e Social. São Paulo, 5 de novembro de 1937. Pront. 4705, da Congregação Israelita Paulista. DEOPS/SP. APESP.

${ }^{207}$ Idem.

208 Taciana Wiazovski. Bolchevismo e Judaísmo, A Comunidade Judaica sob o Olhar do DEOPS, p.31.

${ }^{209}$ Luíza e Ludwig Lorch eram casados e tiveram importante papel junto aos imigrantes judeus recémchegados a São Paulo. Ludwig foi um dos fundadores e Presidente da CIP entre os anos de 1936-1944. O Arquivo pessoal de Ludwig Lorch foi doado pela família à Prof ${ }^{a}$ Maria Luiza Tucci Carneiro, que o colocou sob a guarda do LEER- Laboratório de Estudos sobre Etnicidade, Racismo e Discriminação/USP.
} 
concluiu que as suspeitas aventadas pela Sra. Lucy Bley tinham fundamentos, pois havia apurado devidamente que naquele local haviam entrado inúmeros caixões fechados, presumindo que os mesmos fossem guardados nos fundos da garagem do prédio.

Alceu Martins descobriu ainda que o contrato de aluguel dos inquilinos daquele prédio estava fixado em dois anos, o que interpretou como "naturalmente, com o propósito de dissolver possíveis suspeitas ${ }^{210}$.O Investigador atentou para o fato de que as crianças que eram levadas até ali, diariamente e em número regular, não apareciam em certas ocasiões, porém não haviam sido sequer, retiradas de lá. Constatou também que cestos de roupas carregados para ali, não saiam mais. Além disso, o portão de acesso ao corredor até a garagem, era mantido rigorosamente fechado com cadeado, sendo que não se ouvia ali nenhum sinal de conversa ou ruído, a não ser, de vez em quando, as vozes das crianças. As persianas das janelas abriam-se apenas para tomar sol, estando quase sempre cerradas.

Gostaria de salientar que, entre aquele primeiro relatório e esse, passou-se apenas um dia. Ou seja, com apenas um dia de investigação, Alceu Martins foi capaz de descrever todo o funcionamento da casa, usando expressões generalizadas como "diariamente", "quase sempre”, etc. Não há muita diferença entre a carta de delação de Lucy Bley e os relatórios de investigação de Alceu: ambos demonstram sintomas de uma histeria persecutória. Dando continuidade a essa suspeita, o Delegado de Ordem Social, em 9 de novembro de 1937, expediu uma portaria na qual determinava a procedência de uma rigorosa verificação e apreensão ao prédio 670, “de todo e qualquer material que constituísse objeto de interesse para a Polícia em defesa as ordem política e social",211.

Diante desta Ordem de Serviço, a verificação ordenada foi procedida por Guilherme Pires e Albuquerque, Delegado de Polícia Adido à Delegacia de Ordem Social que apreendeu, entre outros, três fichas mimeografadas em língua portuguesa e alemã, indicando requisitos a preencher para a entrada de estrangeiros em território nacional; três bilhetes redigidos em língua alemã, assinados por pais de alunos,

Atualmente a documentação está sendo higienizada e identificada, guardando a organização do arquivo dada por Ludwig Lorch.

${ }^{210}$ Relatório de Investigação de Alceu de Albuquerque Martins, Inspetor no 228 , ao Delegado de Ordem Social. Superintendência de Ordem Política e Social. São Paulo, 6 de novembro de 1937. Pront. $n^{\circ} 4705$, da Congregação Israelita Paulista. DEOPS/SP. APESP.

${ }^{211}$ Portaria expedida pelo Delegado de Ordem Social. Departamento de Ordem Política e Social. São Paulo, 9 de novembro de 1937. Pront. $n^{o}$ 4705, da Congregação Israelita Paulista. DEOPS/SP. APESP. 
comunicando que, apesar da existência de uma criança doente naquele prédio, não deixariam de enviar seus filhos às aulas; seis circulares contendo instruções sobre ensino e educação, em alemão, organizadas pela CIP; um caderno escrito em língua alemã, contendo o diário do Jardim da Infância "judeu-alemão"; dez prontuários referentes aos alunos matriculados no Jardim de Infância, também em língua alemã; além de exemplares de jornais e revistas editados em Berlim e de um exemplar da Crônica Israelita ${ }^{212}$.

A verificação e apreensão realizada no prédio da Alameda Barão de Piracicaba foi efetuada sem que existissem indícios reais que justificassem o ato. Percebemos que a grande maioria dos materiais apreendidos destinava-se ao fim escolar, o que inocentava o Lar das Crianças. A presença de fichas mimeografadas, indicando requisitos a preencher para a entrada de estrangeiros em território nacional, demonstra a constante preocupação das instituições israelitas em trazer para o Brasil o maior número possível de vítimas do nazismo. Não obstante essas constatações, Charlotte Hamburger, uma das Diretoras da Associação, foi chamada a depor no início de 1938. Essa declarou que no referido prédio estava instalado um "kinderheim" (lar da criança), instituição fundada pela CIP a fim de receber crianças cujos pais trabalhavam e não podiam lhes assistir.

Naquele momento, 26 crianças estavam matriculadas no Lar, sendo 15 delas internas e o restante0 externas. A instituição funcionava desde agosto de 1937 e, não eram ministrados ensinos de quaisquer materiais a não ser trabalhos manuais, não dispondo de um corpo docente, apenas de uma governanta diplomada na Alemanha para este fim. Declarou ainda que aquele estabelecimento não estava registrado na Secretaria da Educação, mas que a diretoria pretendia registrá-lo na Assistência Social, visto que o seu fim era puramente humanitário: visava socorrer crianças, em geral pobres que necessitavam desse amparo $^{213}$. Alice Krauz, também Diretora do Lar das Crianças, assistiu ao depoimento de Charlotte e ratificou o que a amiga havia declarado ${ }^{214}$. Diante do exposto, em 1947, o escrivão Mário Magalhães relatou ao Delegado Especializado

\footnotetext{
212 Auto de Verificação e Apreensão por Guilherme Pires e Albuquerque, Delegado de Polícia Adido à Delegacia de Ordem Social. Departamento de Segurança Política e Social. São Paulo, 9 de novembro de 1937. Pront. $n^{o}$ 4705, da Congregação Israelita Paulista. DEOPS/SP. APESP.

${ }^{213}$ Termo de Declarações de Charlotte Hamburger para Guilherme Pires de Albuquerque, Delegado de Polícia Adido. Delegacia de Ordem Social. São Paulo, 14 de janeiro de 1938. Pront. $n^{o} 4705$, da Congregação Israelita Paulista. DEOPS/SP. APESP.

${ }^{214}$ Termo de Declarações de Alice Krauz para Guilherme Pires de Albuquerque, Delegado de Polícia Adido. Delegacia de Ordem Social. São Paulo, 14 de janeiro de 1938. Pront. $n^{o} 4705$, da Congregação Israelita Paulista. DEOPS/SP. APESP.
} 
que a investigação em torno do prédio 670 não havia sido levada adiante "em decorrência da explicação cabal acerca dos motivos das reuniões realizadas "215.

Percebemos, pois, que não obstante o abismo existente entre os refugiados e o Estado brasileiro, esse último agia no sentido de cercear a ação beneficente e solidária da comunidade judaica brasileira. Situações como estas, contradizem a afirmação de Roney Cytrynowicz, segundo a qual: "As leis anti-imigratórias existentes a partir de 1937, durante a ditadura do Estado-Novo implantada por Getúlio Vargas no Brasil, não interferiram na liberdade comunitária de que os judeus residentes no Brasil desfrutaram entre 1937-1945,"216. Discordamos da opinião de Cytrynowicz que ignora a ação da Polícia Política e as consequiências das Circulares Secretas. As ações policiais ultrapassaram os limites das leis e prejudicaram o andamento das atividades associativas, além de alterar o cotidiano da comunidade judaica.

Atitudes coercitivas por parte da Polícia Política, contra a comunidade judaica, persistiram mesmo durante o governo de Eurico Gaspar Dutra. Em 1948, momento em que a polícia tentava investigar uma suposta ameaça sionista, acreditava-se que o Lar da Criança estivesse empreendendo “(...) forte propaganda do lar judeu, aconselhando seus componentes a auxiliarem a campanha em que se meteram os judeus". 217

Tanto a CIP, como o Lar das Crianças, ocuparam o espaço deixado em aberto pelo governo varguista, possibilitando ao imigrante, adulto ou criança, as ferramentas necessárias para desenvolver uma vida autônoma. A ajuda prestada aos refugiados por essas associações iniciava-se desde o momento da solicitação do visto, ainda no país de origem, estendendo-se até a ajuda na criação de seus filhos em território brasileiro. A importância destas estratégias na vida dos refugiados judeus ultrapassa assim, os limites das redes de solidariedade, para se constituir numa verdadeira frente de resistência ao nazi-fascismo e ao autoritarismo do governo Vargas.

\footnotetext{
215 Comunicado de Mario Magalhães, escrivão, para o Delegado Especializado de Ordem Política e Social. Departamento de Ordem Política e Social. Pront. $n^{\circ} 4705$, da Congregação Israelita Paulista. DEOPS/SP. APESP.

${ }^{216}$ Roney Cytrynowicz, Op.cit, p.26.

${ }^{217}$ Relatório de Paulo Philbert para Manoel Ribeiro da Cruz, Delegado Especializado de Ordem Política. Departamento de Ordem Política e Social. São Paulo, 18 de junho de 1948. Dossiê no $50-J-67$ de Sociedades Estrangeiras. DEOPS/SP. APESP.
} 


\section{III - REDES DE SOLIDARIEDADE}

\section{1 - O Auxilio Além- Mar}

A trajetória da Congregação Israelita Paulista esteve intimamente relacionada e, em alguns momentos, até mesmo dependente, do American Jewish JOINT Distribution Committee (JOINT e posteriormente JDC). Fundada em 1914, por um grupo de judeus norte-americanos, esta instituição objetivava, inicialmente, ajudar a comunidade judaica radicada na Palestina e na Europa durante a Primeira Guerra Mundial. O sucesso da operação e a contínua necessidade de auxilio por parte da comunidade judaica do Leste europeu, nas décadas de 1920 e 1930, solidificou essa associação que, por volta de 1945, chegou a contar com três escritórios em território brasileiro: Porto Alegre, Rio de Janeiro e São Paulo.

Durante a Segunda Guerra Mundial, o JOINT, através de seu escritório em Paris, direcionou suas atenções para a comunidade judaico-alemã, possibilitando a fuga de cerca de 375.000 judeus da Alemanha e da Áustria. A invasão alemã à França em 1940 obrigou o escritório europeu do JOINT a se mudar para Lisboa, de onde muitos outros judeus foram ajudados a deixar a Europa, além daqueles que foram mantidos em esconderijos durante a guerra. Não obstante sua importante atuação, o JOINT não conseguiria alcançar esse sucesso se não contasse com a ajuda de outras organizações judaicas espalhadas pelo mundo. Enquanto ao JOINT cabia o patrocínio financeiro e o planejamento logístico, a CIP cuidava da recepção e da regularização da situação do imigrante, além de, em alguns casos, providenciar seu visto de imigração e suas passagens para o Brasil.

O recebimento de importantes recursos financeiros durante a II Guerra, levou o JOINT a contribuir com a formação de algumas associações beneficentes judaicas pelo mundo, entre elas a CIP. Impelidos pela grave dificuldade financeira que acometeu a CIP em seus primeiros anos, o casal Ludwig e Luiza Lorch viajaram à Nova York, sede mundial do JOINT, por diversas vezes em busca de empréstimos. Iniciava-se então, uma forte relação que perduraria durante toda a Segunda Guerra e, em seus anos subseqüentes. Àqueles empréstimos cessariam em 1942, momento em que a Congregação conseguiu equilibrar suas contas e aumentar sua receita. Anos depois, a colaboração entre ambas as associações seria marcada pela criação, em 1946, do Comitê Auxiliar do JOINT, instituição ligada à CIP. 
Entre 1937 a 1942, o JOINT lidou diretamente com Ludwig Lorch, Salo Wissmann, Martin Friedmann e Hans Hamburger que formavam uma equipe de comissários e intermediavam as conversações entre a comunidade judaico-paulistana e a sede do JOINT em Nova York. Estes homens intitulavam-se "a Comissão dos Três". Apesar do sucesso da parceria, ainda em 1942, o Presidente do Sub-comitê JOINT das Américas do Sul e Central em carta para Lorch e Wissman, pressionava no sentido da formação de um comitê especializado para lidar com o JOINT, cuja política impedia negociações com indivíduos em forma de trustees. Segundo ele, a legalização jurídica e institucional da Congregação Israelita, enquanto entidade beneficente, possibilitava que essa associação tomasse para si o trabalho de direção no programa de ajuda aos refugiados $^{218}$. Nesse sentido, a substituição dos comissários por um Comitê interno à CIP, facilitaria a divulgação dos aspectos funcionais do JOINT, transmitindo informações a respeito da situação da comunidade judaica internacional, e direcionando os esforços dos diversos agrupamentos judaicos paulistanos para o mesmo fim de auxílio às vítimas.

"Você têm promovido um progresso real em familiarizar os diversos grupos que compõe a comunidade judaica. (...). É nossa opinião que o objetivo de união de interesses e esforços será alcançado mais rapidamente quando os vários grupos estiverem informados sobre o trabalho que você tão bem começou e desenvolveu. A Congregação Israelita Paulista parece-nos ser um instrumento que pode contribuir muito para a realização desse objetivo". ${ }^{219}$

A busca pela mobilização do maior número possível de membros e organizações da comunidade devia-se à crescente demanda por recursos financeiros, necessários para o patrocínio da viagem e da legalização dos imigrantes em seus novos países. Assim, em junho daquele mesmo ano, os ex-trustees anunciaram ao Sub-Comitê das Américas do Sul e Central sua decisão em repassar suas atividades como comissários para o setor de Assistência Social da $\operatorname{CIP}^{220}$.

\footnotetext{
${ }^{218}$ Carta de Alfred Jaretzki Jr., Presidente do Sub-Comitê de Ajuda aos Refugiados nas Américas do Sul e Central, para Ludwig Lorch e Salo Wissman. Nova York, 6 de fevereiro de 1942. Fundo Lorch. LEER/USP.

219 "You have made real progress in acquainting the several groups of which the Jewish community is composed (...) It is our feeling that the goal of unity of interest and effort will be more rapidly approached the several groups become informed about the work which you have so well begun and developed. The Congregação Israelita Paulista seems to us to be the instrumentality which can contribute much to the achievement of that aim.” Idem.

${ }^{220}$ Carta de Robert Pilpel, Secretário do Sub-Comitê de Ajuda aos Refugiados nas Américas do Sul e Central, para Ludwig Lorch, Salo Wissman, Martin Friedmann e Hans Hamburger. s/d. Fundo Lorch. LEER/USP.
} 
Em 1942, segundo dados cadastrais da CIP, o número de imigrantes judeus em São Paulo, alcançava a cifra de 8.000 pessoas, provenientes em sua maior parte - cerca de 3.725 - da Alemanha. Desses, mais de 1.600, deviam dinheiro à Congregação naquele mesmo ano. Por outro lado, o JOINT não possuía, por si só, recursos suficientes para cobrir todas as despesas necessárias, esperando sempre a devolução dos empréstimos feitos e o afluxo de novas doações. A somatória desses fatores levou a CIP a uma grave crise financeira no ano de 1942, agravada pela pressão do JOINT no sentido de conhecer as despesas e receitas da associação, a fim de lhes enviar menos recursos no ano seguinte.

"Se nós formos agora reembolsar você pelos 12.527,60 seria uma considerável bala e em vista do fato de você estar recebendo dinheiro da campanha local, nós ficamos curiosos se a soma gasta com a legalização não pode ser paga por fora dessa arrecadação". ${ }^{221}$

$\mathrm{Na}$ verdade, os representantes do JOINT desconheciam a situação real da campanha local de 1941. Em novembro de 1942, Salo Wissmann em reunião com os outros comissários do JOINT, informava que não havia mais dinheiro em caixa, pois, muitos daqueles que haviam prometido doações para a campanha de 1941, não estavam cumprindo com o acordado. A solução para que a Assistência Social da Congregação continuasse a existir, seria, então, tomar empréstimos de particulares e contar com contribuições extras dos grandes doadores, como a família Klabin ${ }^{222}$.

A legalização constituía a terceira maior despesa da Congregação, atrás somente do Relief e da assistência médica, segundo os dados de 1941-42. Nesse ano discutia-se a modificação na forma da cobrança das mensalidades dos sócios, já que apenas 25 deles arcavam com a contribuição máxima de mais de $30 \$ 000$ por mês, enquanto a grande maioria, 753, pagava apenas a taxa mínima de 7\$500 mensais. Não obstante, sabia-se que a maior parte daqueles que contribuíam minimamente, estava em boas condições financeiras e podia aumentar suas mensalidades. Decidiu-se então, atrelar o valor mensal a ser pago por cada sócio, ao valor de seus aluguéis, pois, assim, não haveria

\footnotetext{
221 "If we were now to reimburse you for the 12,527.60 there would be a considerable bala and in view of the fact that you are receiving money from the local campaign, we wonder if the sums expended for legalization cannot be paid for out of the collection". Carta de Robert Pilpel, do American Jewish JOINT Distribution Committee para Hans Hamburger. Nova York, 28 de Janeiro de 1942. Fundo Lorch/LEER USP.

${ }^{222}$ Ata da Reunião a respeito dos fundos da Campanha de 1941. São Paulo, 16 de novembro de 1942. Fundo Lorch/LEER - USP.
} 
como escapar a obrigação com a Congregação ${ }^{223}$. Quanto à pressão feita pelo JOINT, a única resposta possível era a seguinte:

"Você entenderá que nós devemos entrar em dificuldades de pagamento severas quando as remunerações do Drive, como agora, não forem suficientes para cobrir as despesas. Assim nós encaramos o perigo de precisar interromper de repente o nosso trabalho se nós continuarmos com nosso déficit em descoberto. (...) Nós, por essa razão, pedimos a você imediatamente para reexaminar com urgência essa questão e nos garantir pelo ou menos a quantia de $\$ 6.000$ a $\$ 8.000$ para compensar o déficit.,"224

A estratégia do JOINT era sempre a de fomentar campanhas locais e Drives unificados a fim de diminuir ao máximo a dependência de seus comitês, garantindo que os mesmos se auto-sustentassem. A campanha de 1941, citada acima por Hans Hamburger, contou com farta propaganda e procurou sensibilizar a comunidade judaico-paulistana através de relatos e explicações sobre tudo o que estava acontecendo com os judeus na Europa.
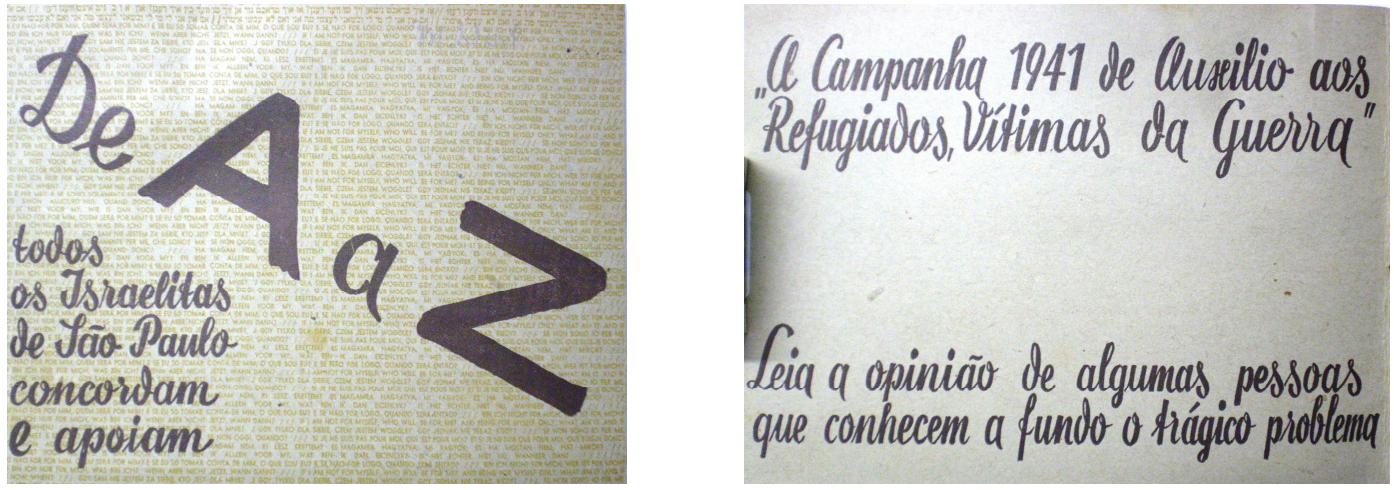

- Cartão distribuído pela Congregação Israelita Paulista durante a Campanha de 1941. Fundo Ludwig Lorch, LEER-USP.

O cartão De A a Z, continha em suas oito páginas mensagens de membros da comunidade judaico-paulistana, atentando para a obrigação que os judeus tinham de ajudar aqueles que estavam em pior situação. Além disso, procurava-se sensibilizar os doadores em potencial através da descrição das dificuldades passadas por seus "irmãos"

${ }^{223}$ Cópia da Ata de Assembléia dos Representantes da Congregação Israelita Paulista. São Paulo, 1941. Fundo Lorch/LEER - USP.

224 "You will understand that we must come into acute paying-difficulties when the payments of the Drive, as presently, do not enter sufficiently to cover the disbursements. So we face the danger to have to interrupt suddenly our work if we have to continue with our uncovered deficit. (...) We, therefore, beg you instantly to reexamine urgently this question and to grant us at least the amount of $\$ 6000$ to $\$ 8000$ for covering the deficit..." Carta de Hans Hamburger para o American Jewish JOINT Distribution Committee, em Nova York. São Paulo, 8 de março de 1942. Fundo Lorch/LEER - USP. 
na Europa: "Não vivemos só para nós. As pessoas perseguidas e escravizadas na Europa são uma parte de nós e os sofrimentos dela são os nossos sofrimentos. Ajudar é um dever natural." ${ }^{225} \mathrm{Na}$ última página do cartão, podia-se encontrar uma espécie de "bolsinho", feito em papel, reservado para o depósito das doações.

As doações eram pedidas também pelo próprio JOINT, por intermédio da Congregação. Naquele mesmo ano, outro instrumento utilizado para sensibilizar a comunidade judaica foi um livreto produzido pela JOINT, em português, e divulgado pela CIP entre seus sócios, sobre a situação dos judeus atingidos diretamente pela Segunda Guerra Mundial. Através de fotografias que procuravam retratar o sofrimento das vítimas e de textos explicativos sobre o genocídio judeu na Europa, a publicação buscava causar grande impacto nos leitores, levando-os a contribuir com a campanha internacional de 1941 organizada pela JOINT.
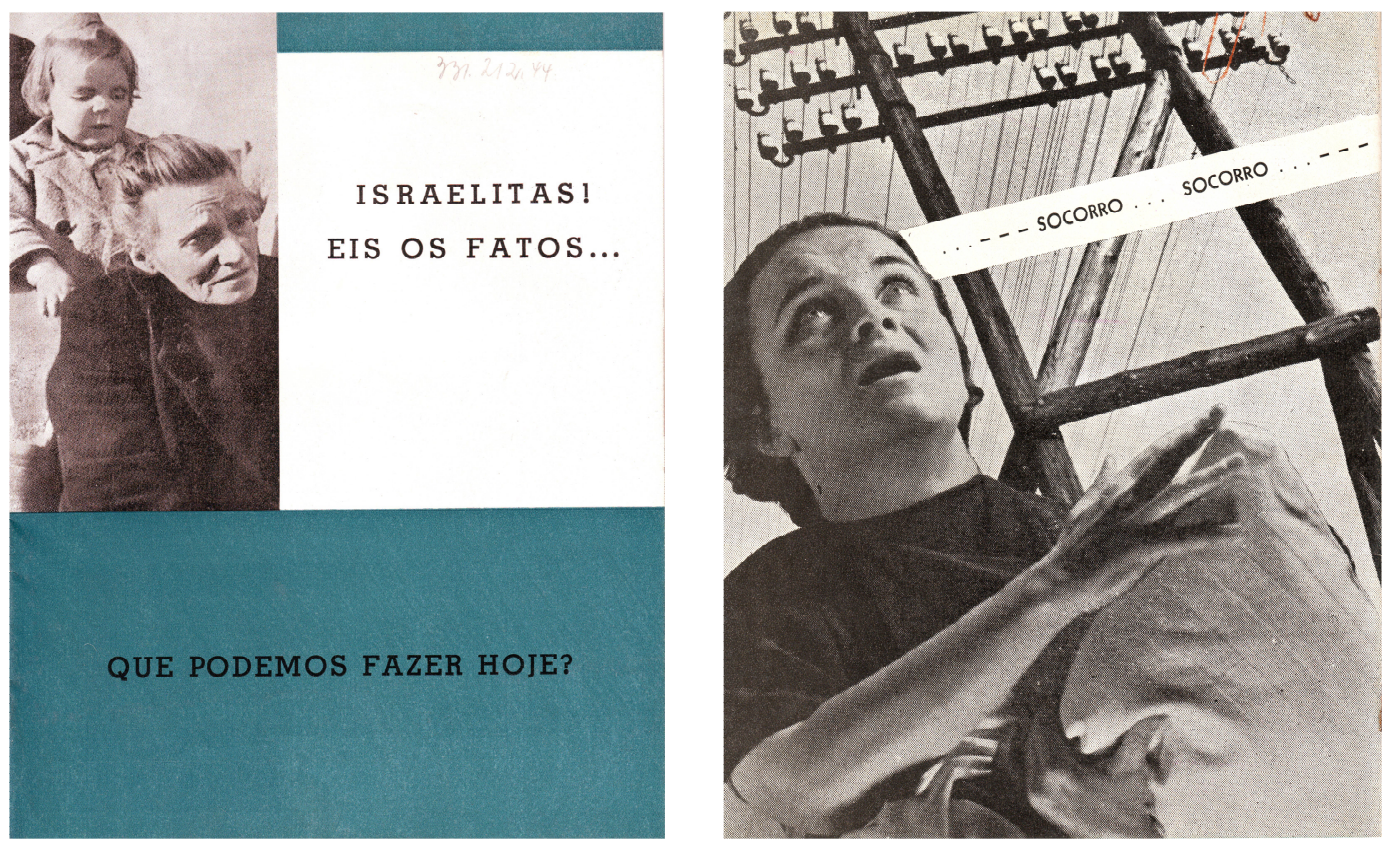

- Livreto "Que podemos fazer hoje?” distribuído pela Congregação Israelita Paulista em 1941, Capas. Fundo Ludwig Lorch, LEER-USP.

No último trimestre de 1940, as dificuldades financeiras do JOINT também se agravavam. Naqueles meses, era necessária para a associação uma receita de, pelo ou menos, \$1.000.000 por mês, dos quais a maior parte seria destinada a facilitar a emigração de judeus de alguns países da Europa. Além disso, a associação devia aos

\footnotetext{
${ }^{225}$ Declaração de José Aron Barmak em cartão distribuído pela Congregação Israelita Paulista durante a Campanha de 1941. Fundo Ludwig Lorch/LEER-USP.
} 
bancos norte-americanos e estrangeiros empréstimos que totalizavam o montante de $\$$ 2.270.000, referentes apenas àquele ano. Segundo o livreto do JOINT, no decorrer da II Grande Guerra, organismos importantes de auxílio às vitimas judaicas, como o Conselho Central Britânico para Refugiados Israelitas e a Associação Colonizadora Israelita, haviam sido fechados, deixando de cumprir com boa parte dos gastos com programas de amparo aos refugiados. Desse modo, "o JDC resta como única fonte de auxilio para centenas de milhares de israelitas na Europa. ${ }^{, 226}$ Para 1941, previa-se que a entidade teria gastos de, no mínimo, \$23.000.000.
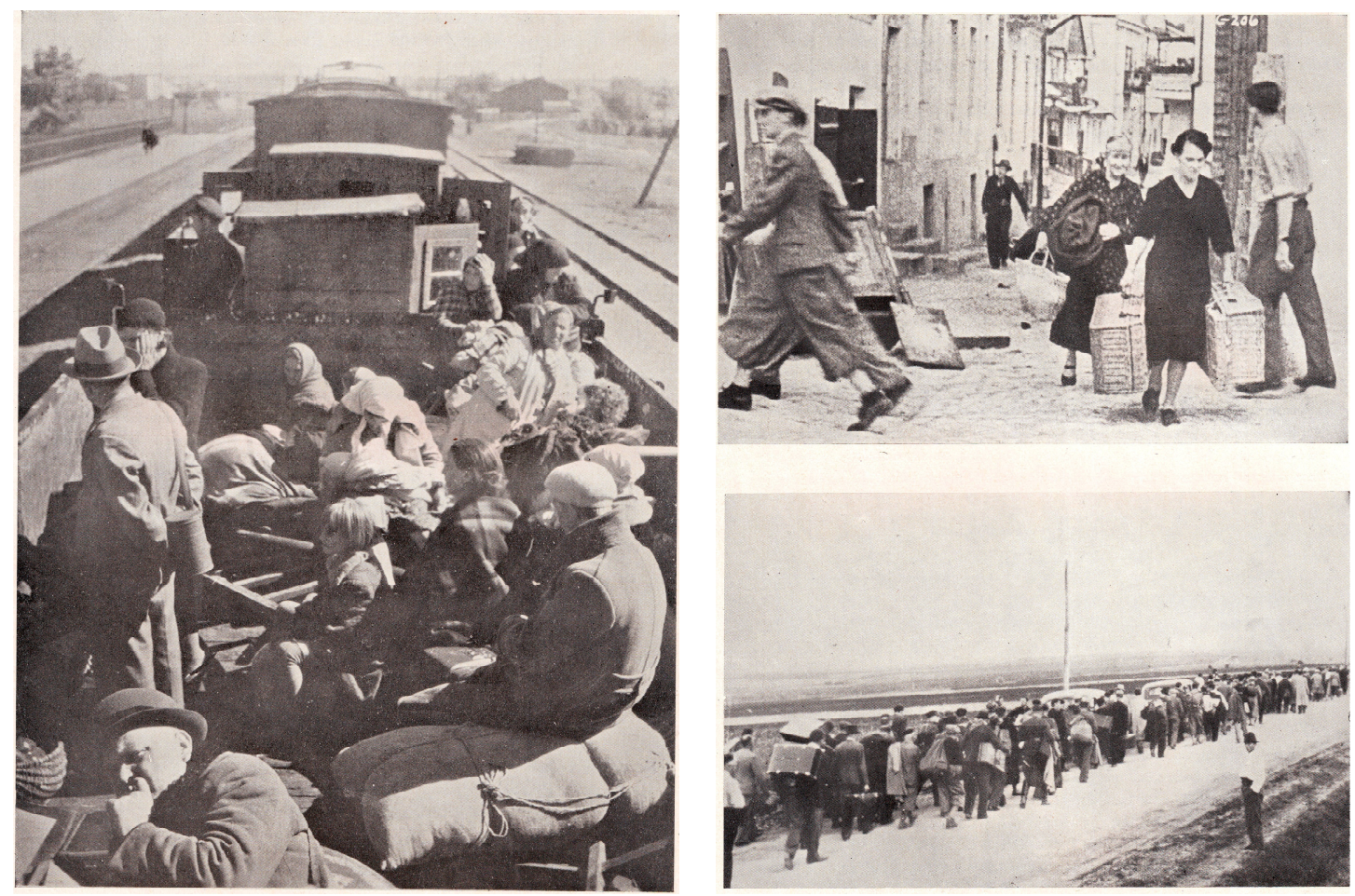

- Fotografias publicadas no livreto "Que podemos fazer hoje?" distribuído pela Congregação Israelita Paulista em 1941, pp. 08 e 12. Fundo Ludwig Lorch, LEER-USP.

Havia, naquele momento, cerca de 8.600 refugiados judeus prontos para emigrar da Europa, com passaportes e vistos concedidos No entanto, os fundos do JOINT eram suficientes para patrocinar a viagem de apenas 1.500 dentre aqueles. Existiam também os refugiados internados em campos de concentração em áreas não ocupadas, como o campo de St. Cyprien, na França, para os quais era preciso enviar roupas quentes, cobertores, alimentação e remédios. Na Polônia, a situação era ainda mais crítica:

\footnotetext{
${ }^{226}$ Livreto "Que podemos fazer hoje?” distribuído pela Congregação Israelita Paulista. 1941. Fundo Ludwig Lorch, LEER-USP, p. 07.
} 
metade dos 1.200.000 judeus da região não possuía condições sequer de fazer uma única refeição ao dia. Nesse país, ainda que ocupado pelas tropas alemãs, o JOINT conseguia manter "um grande número de postos de cozinha para adultos e crianças". Porém, a grave crise financeira da instituição obrigara-os a fechar os postos para adultos, mantendo apenas àqueles para crianças ${ }^{227}$.
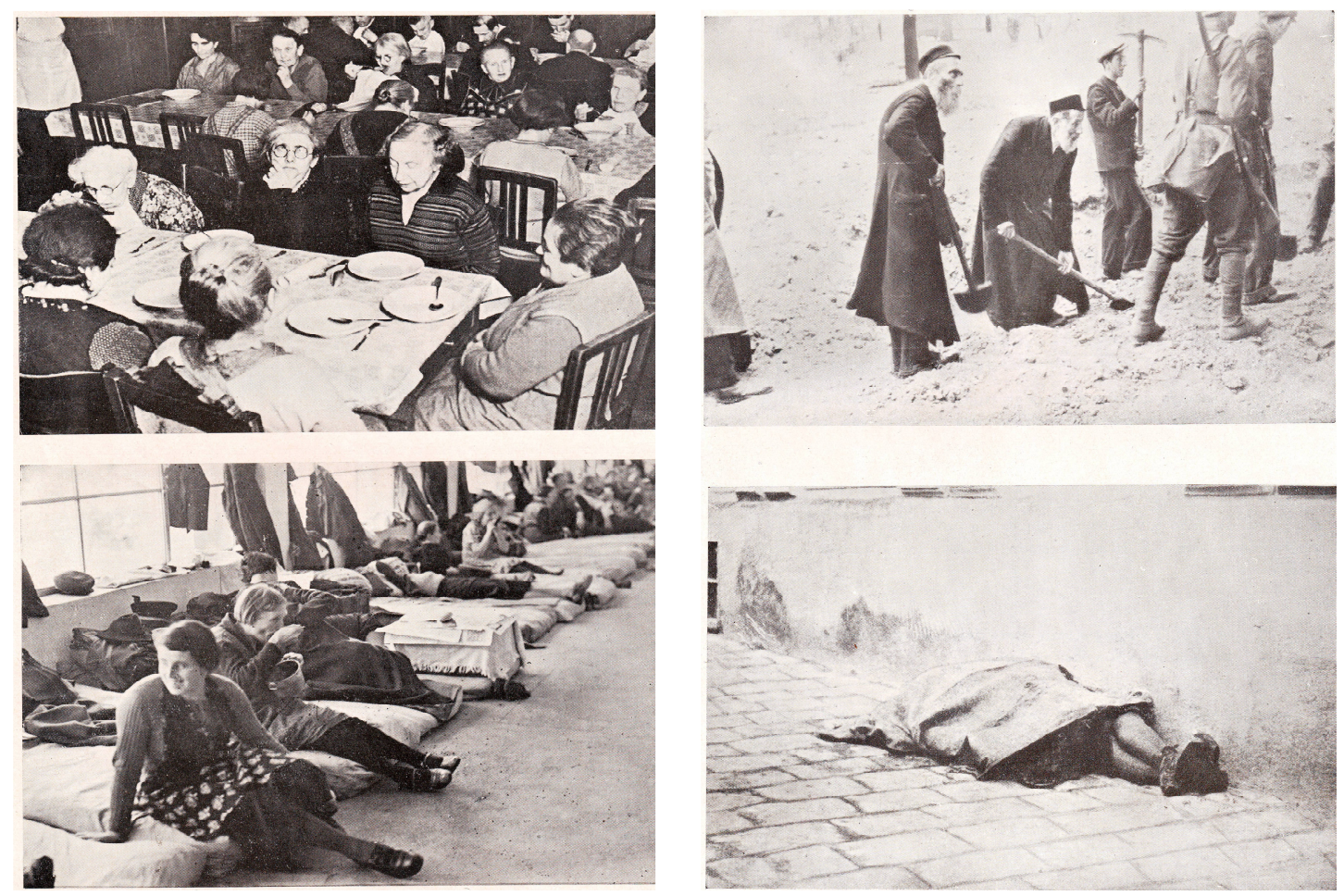

- Fotografias publicadas no livreto "Que podemos fazer hoje?" distribuído pela Congregação Israelita Paulista em 1941, pp. 14 e 05. Fundo Ludwig Lorch, LEER-USP.

Importante salientar que, durante a Segunda Guerra Mundial, o JOINT se recusava a enviar dólares para as áreas ocupadas pelo exército alemão. Nessas áreas, a solidariedade se dava através do envio direto de objetos, agasalhos e alimentação, sem que houvesse a remessa de dinheiro.

Em relatório especial, Morris C. Troper, Presidente da JOINT na Europa descreve nos seguintes termos a situação dos judeus naquele continente:

"Houve um tempo em que havia, como em toda a parte, duas classes de israelitas na Europa - os que podiam ajudar e os que deviam ser ajudados. Aquele tempo passou. Qualquer que tenha sido sua antiga situação econômica, os israelitas da Europa, homens, mulheres e crianças, estão hoje numa única classe de miséria e desespero.

${ }^{227}$ Livreto “Que podemos fazer hoje?” distribuído pela Congregação Israelita Paulista. 1941. Fundo Ludwig Lorch, LEER-USP, p. 07 
Nada tem a esperar senão fome, doença e extermínio final, a não ser que se possa socorrê-los, e imediatamente.,"228

Após descrever a situação dos judeus na Europa, Morris Troper prossegue, explicando porque os judeus de além-mar precisavam ser ajudados por aqueles que se encontravam no continente americano e, porque a Cruz Vermelha Internacional seria incapaz de proporcionar aquela ajuda:

“(...) Israelitas além-mar além de participar nos males comuns de todos os povos em guerra, estão sujeitos a encargos especiais de discriminação, perseguição, desvantagens legais e físicas, e que esses últimos sofrimentos, lhes são impostos porque são israelitas (...) Se pudesse mostrar, nesta sala, uma criança israelita, esfarrapada, amedrontada, a barriga dilatada de fome, que lhes suplicasse um pedaço de pão para acalmar sua dor, não haveria um homem cujas dúvidas, perguntas e hesitações não desaparecessem imediatamente. Correriam para dar de comer àquela criança...Multiplicar essa imagem por dezenas de milhares dará idéia do problema que hoje enfrentamos....."229

Notamos aqui, a tentativa de Morris Troper em sensibilizar e unificar os esforços dos judeus da Diáspora em torno dos excluídos vitimados pelo anti-semitismo. O início do regime hitlerista na Alemanha, e o recrudescimento do anti-semitismo na Europa Central e do Leste, serviram para restabelecer entre os judeus o apego à sua cultura e religião, contribuindo para a união e ajuda mútuas. Para Troper, os judeus não seriam vítimas comuns, pois, essas, apesar de terem perdido suas casas e seus empregos, ainda possuíam um mínimo de dignidade, com a possibilidade de se adaptar a uma vida regida pelo nazi-fascismo. Porém, para os judeus essa opção não era válida, já que não lhes restava nem dignidade e nem oportunidades econômicas. A única alternativa seria, então, reconstruir suas vidas em outros lugares. Buscando causar impacto sobre os leitores, Troper relata ainda a condição subumana vivenciada por muitas crianças judias na Europa, situação da qual, apenas a bondade dos doadores poderia livrá-las. ${ }^{230}$

JOINT e CIP compunham assim, duas instituições em mútua dependência: em relação às informações repassadas entre ambas, financeira, em nome de tantos que haviam conseguido se estabelecer no Brasil e, agora, clamavam por notícias daqueles que ficaram na Europa e, em contrapartida, por parte daqueles que ainda estavam na Europa e buscavam perspectivas de sobrevivência fora dali. Em nome desses últimos e sempre que possível, o trabalho de assistência social da CIP ultrapassou as barreiras

${ }^{228}$ Livreto "Que podemos fazer hoje?" distribuído pela Congregação Israelita Paulista. 1941. Fundo Ludwig Lorch, LEER-USP, p. 09.

${ }^{229}$ Ibid. p. 10.

${ }^{230}$ Ibid. p. 07. 
nacionais tentando alcançar as vítimas da Segunda Guerra Mundial na Europa e, até mesmo, a nova sociedade que se formava em Israel. Assim, enquanto a assistência social tentava cuidar daqueles refugiados que já viviam em território nacional, o subdepartamento "Além-mar" pretendia ajudar aos necessitados dos países devastados pela guerra e possibilitar sua imigração para o Brasil.

As atividades do "Auxílio Israelita Além-mar" foram organizadas em outubro de 1944, com o apoio do JOINT. Suas ações voltavam-se para a "localização de pessoas; orientação em questões de re-adaptação e migração; orientação a respeito do auxilio financeiro e material, assim como a angariação de fundos, víveres, roupas, medicamentos, etc; serviço informativo. "231 O departamento contava ainda com as presenças de Ludwig Lorch, Hans Hamburger, Alfred Hirschberg, Salo Wissmann e Guilherme Krausz entre seus principais colaboradores. Seus trabalhos, propriamente ditos, iniciaram-se em 1945 com a formação do "serviço de pacotes", através do qual judeus residentes em São Paulo poderiam enviar, além de dinheiro, mantimentos e remédios para seus parentes e amigos na Europa. As doações angariadas eram divididas em duas partes: cerca de 2/3 iriam diretamente para os escritórios do JOINT nos Estados Unidos e Europa, enquanto que o 1/3 restante era colocado à disposição do Além-mar de São Paulo e distribuído pela própria CIP $^{232}$.

Em 1945 esse departamento da CIP, em estreita colaboração com a OFIDAS, promoveu três grandes remessas de roupas e alimentos para a Europa. Outra estratégia acionada pela CIP para angariar doações, naquele mesmo ano, foi a "Campanha da Boa Vontade", que lhe rendeu cerca de $\mathrm{Cr} \$ 650.000,00^{233}$. Em resposta à sua atuação, a Congregação conseguiu ainda, registrar-se junto à Cruz Vermelha Brasileira o que lhe possibilitava enviar suas remessas diretamente para os escritórios centrais do JOINT no exterior, principalmente àqueles situados na Europa. Além da OFIDAS, a ARI Associação Religiosa Israelita - também contribuiu nesta campanha. Entre o último mês de 1945 e o final de 1946, a CIP conseguiu reunir e enviar 798 pacotes para a Europa e, em 1947, esse número chegaria a 1981 pacotes! ${ }^{234}$

\footnotetext{
231 Ata da Reunião do Conselho das Comissões da Congregação Israelita Paulista. São Paulo, 5 de outubro de 1944. Fundo 187/AHJB.

${ }^{232}$ Ata da Reunião da Diretoria da Congregação Israelita Paulista. São Paulo, 19 de junho de 1945. Fundo 187/AHJB.

${ }^{233} \mathrm{O}$ equivalente à U\$ 26.000,00. Dado contido em rascunho de relatório de Ludwig Lorch a respeito da situação do "JOINT" em São Paulo. São Paulo, 1948. Fundo Ludwig Lorch, LEER-USP.

${ }^{234}$ Crônica Israelita 10 anos. Dezembro de 1946. Dez. Anos de Construção da Congregação Israelita Paulista. Fundo 187/AHJB.
} 
Apesar do consolo proporcionado por essas atividades, para aqueles que viviam na ânsia de noticias por seus entes queridos, na Europa do pós-guerra, essas medidas eram apenas paliativas:

"Não há dúvidas de que todos esses serviços dão conforto aos remetentes no Brasil e ajudam os necessitados na Europa a sobreviver. Mas muito mais importante para os parentes aqui é a possibilidade de salvar os seus queridos definitivamente chamando-os para o Brasil. Por isso o serviço em redor da imigração é o mais importante e, também o mais difícil". ${ }^{235}$

No final de 1944, após a abertura dos campos de concentração nazistas e a libertação das áreas dominadas pelo exército de Hitler, as associações judaicas espalhadas pelo mundo foram inundadas por pedidos de pessoas que buscavam por seus parentes e amigos, sobreviventes da Shoá. Tal demanda levou o JOINT, em parceria com outras organizações judaico-internacionais, a instalar nos Estados Unidos, o Central Location Index que, em união com a Cruz Vermelha Internacional, seria o órgão responsável pela localização de pessoas e pelo repasse de correspondências provenientes dos campos de refugiados da Alemanha e Áustria.

Logo no início das atividades do Central Location Index, a CIP enviou 615 formulários de israelitas radicados no Brasil que buscavam informações a respeito de 2.000 pessoas desaparecidas durante a Segunda Guerra. Apesar de um início difícil, segundo Hans Hamburger, "com o decorrer do tempo os meios de investigação melhoraram e mesmo agora recebemos às vezes notícias sobre pessoas sobreviventes antes dos parentes" 236 . Atuando como parte dessa rede de solidariedade e informações, a Congregação recebia, através de comitês sediados em vários países europeus, pedidos de informações sobre pessoas residentes em São Paulo. Assim, durante o ano de 1946, a CIP foi a responsável por atender a mais de $70 \%$ dos pedidos de busca por amigos e parentes, o que totalizou cerca de 500 pessoas encontradas no Estado paulista. Em 1945, foram localizadas 309 pessoas e, outras 229 em 1947. A busca era feita a partir dos fichários das associações, nos quais constavam os dados de todos os auxiliados, através do anúncio dos nomes dos procurados em jornais, como a Crônica Israelita, e através de transmissões pelo rádio ${ }^{237}$.

\footnotetext{
${ }^{235}$ Crônica Israelita 10 anos. Dezembro de 1946. Dez. Anos de Construção da Congregação Israelita Paulista. Fundo 187/AHJB.

${ }^{236}$ Idem.

237 Relatório do Conselho sobre as Atividades da Congregação Israelita Paulista de 1945 a 1947. São Paulo, 18 de dezembro de 1947. Fundo 187/AHJB.
} 
O fim da Segunda Guerra Mundial e a abertura dos campos de concentração provocaram a dispersão de milhares de sobreviventes judeus pela Europa. A grande maioria estava pobre e doente, sem qualquer resistência física devido à subalimentação sistemática e ao tratamento brutal que recebeu dos nazistas. Em relação aos adultos, esses não possuíam emprego ou qualquer outro tipo de fonte de renda, enquanto que as crianças, em sua maioria órfãs, amontoavam-se nas creches mantidas pelo JOINT e pela HIAS. Assim, o número de pessoas carentes de auxilio e assistência aumentava a cada dia. Segundo o relatório "Para que tornem a viver" produzido pelo JOINT ao final de 1945, seria necessário empregar, no ano seguinte, cerca de 58.350.000 dólares a fim de satisfazer minimamente as necessidades dos judeus de além-mar. A instituição afirmava ainda, que cerca de $50 \%$ dos sobreviventes do Holocausto na Europa dependiam diretamente dos seus cuidados:

\begin{abstract}
"Os cem mil judeus deslocados que ainda permanecem nos vários campos e centros na Alemanha, Áustria e Itália, não somente perderam o que lhes pertencia, perderam também sua fé nos Aliados que vieram para libertá-los, e por cuja chegada rezaram fervorosamente na terrível noite de sua opressão. Não sabem compreender o motivo pelo qual, meses depois da libertação, eles continuam ainda mal nutridos, pobremente agasalhados e vivendo ainda nos países que foram cenário dos seus sofrimentos inenarráveis e cujo solo é túmulo dos entes que lhe foram caros". 238
\end{abstract}

O auxilio sustentado pelos Aliados consistia basicamente na formação dos campos de Displaced Persons e na tentativa de repatriação dos sobreviventes. No entanto, para a grande maioria dos judeus que havia conseguido sobreviver à guerra e ao Holocausto, a única forma de recomeçar suas vidas seria longe da Europa. O trauma e a desilusão para com a sua pátria de origem, principalmente no caso dos alemães, eram sentimentos comuns a todos os sobreviventes. Nos anos que sobrevieram ao fim da II Guerra, os escritórios do JOINT na Europa foram inundados por pedidos de pessoas que queriam emigrar, principalmente para os países do continente americano e para a Palestina. Além disso, os campos de pessoas deslocadas mantidos pelos Aliados, ainda que em caráter temporário, acabaram por se tornarem permanentes e não estavam preparados para prover de maneira eficiente a todos aqueles que precisavam de ajuda. Assim, na visão do JOINT, o ano de 1946 seria decisivo para toda a comunidade judaica.

\footnotetext{
${ }^{238}$ Para que tornem a viver. Relatório Anual de 1945 do JOINT Distribution Committee. Fundo Alfred Hirschberg/AHJB.
} 
Os relatórios produzidos pelo JOINT eram anuais e serviam como uma espécie de "prestação de contas", informando o total de recursos arrecadados pela organização, a aplicação desses recursos e uma previsão do quanto seria necessário para o ano seguinte. Como possuía associações conveniadas em vários países, esses relatórios eram impressos em diversas línguas, como inglês, espanhol e português. Os relatórios em português eram enviados, entre outras, para a CIP que os repassava à sua diretoria e aos seus conveniados.

Uma das principais consequiências do fim da Segunda Grande Guerra foi o aumento no afluxo de deslocados e refugiados pela Europa, exigindo a intensificação dos trabalhos das associações judaicas para os auxílios além-mar. Hans Hamburger, no final do ano de 1945, chamava a atenção para a importância de se criar um comitê de emergência, "formado na perspectiva duma imigração considerável". Segundo ele, o comitê não deveria atuar apenas como uma organização beneficente, mas coordenar o trabalho de todas as associações beneficentes judaicas em São Paulo, na tentativa de obter "uma colaboração íntima, a fim de criar condições psicológicas favoráveis aos novos imigrantes." ${ }^{239}$ A fïm de solucionar a questão da ampliação dos serviços alémmar, Salomão Resznick, Delegado do JOINT em São Paulo, propôs para a Diretoria da Congregação a formação de uma "Junta" que, enquanto órgão ligado ao JOINT, se incumbiria da angariação de fundos para a Europa e Palestina. Seria a declaração de autonomia do subdepartamento além-mar. Entendendo que aquela Junta não interferiria nos assuntos da assistência local e na colaboração direta entre a Congregação e o JOINT, a CIP concorda com sua formação, colocando à disposição da nova organização todo o seu aparelhamento pessoal e material. Hans Hamburger, Guilherme Krausz e Salo Wissmann passavam então, a integrar o quadro de Vogais da Junta que, ao final de 1945, intitulou-se Comitê Auxiliar do JOINT. Nos postos de Presidente e Vicepresidentes encontravam-se Horácio Lafer, Ludwig Lorch e Paulo Krumholz, respectivamente.

A partir daquele momento, o Comitê Auxiliar do JOINT passaria a ser o responsável por amealhar quaisquer recursos financeiros que pudessem ser enviados aos escritórios centrais do JOINT. Em panfleto veiculado junto à comunidade judaicopaulistana, o Comitê informava seus cinco objetivos centrais:

\footnotetext{
239 Ata da Reunião da Assembléia dos Representantes da CIP. São Paulo, 18 de novembro de 1946. Fundo 187/AHJB.
} 
O QUE E E O QUE ZAZ O "COMITE AUXILIAR DO "J O I N T

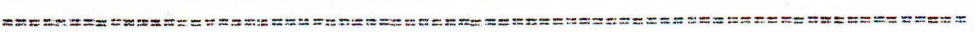

palo Dr. H. Szulo

Dirotor Executivo.

A historla do "JoIN" s a hatória do auxilio dado a todos os beres humanos pergeguidos no univergo, Na sua atividade de pais te 31. smos, o "JoINT" provou suficientemente sev caracter spolitico,isento do qualquer preconcelto nacional, racial ou religiobo. Tundado no ano de 1914 , ao iniciar ge a primeira guerra mundia], o "JOTN" ampliou as ano a mo as suas utividades, tormando-se aseim uns instituiça verdsdeiremen te internacional, com representaçres e flilals ex todas as oidades inportantes do universo.

**:

Não era,p01в, poselvel que delxasge de tex sua reprasentaço no BRASII, desde que já as possula em todos os continentes. Tendo-se instalado o Comité en Buenos A1res, Argentina no ano de 1943, fundou-ge em fins de 19450 "CONITE AJXIIIAR DO JOINT" om SEO Paulo, cujos destinos sto regldos pelas personalidades seguintea:

Presicente: Dr.Horagio Lafer; Vioeprenidentes: Dr. Luiz Lorch e Dr.Faulo Krumholz; Secretarios: V1ttorio Camerini e Berrarjo Iifschitz; Teeoureiros: Devid Proughan e Hermann Frank; Togaja: José Algranti, Dr. Hans Hemburger, Albert Rofman, Stefan Lendau, Samel Xlabin, Guilherme P. Breugz, Jaidoro Metzgar, Meier Okret,

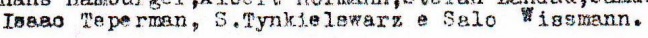

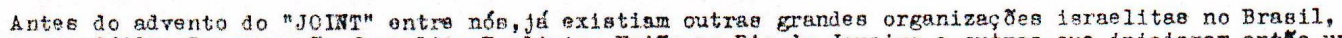

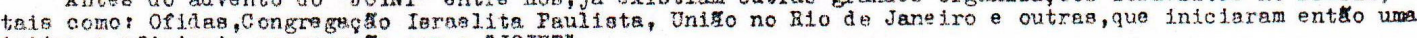
intima e eficiente copsragko com o "Joxt"

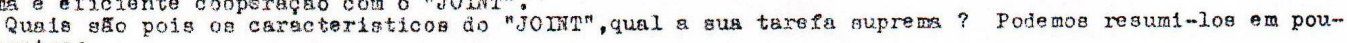
cos pontos:

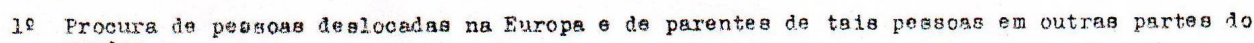
mundo:

28 Frocuxa de Pamlise residentos no Brasil, o pedido das pessoas desloceder;

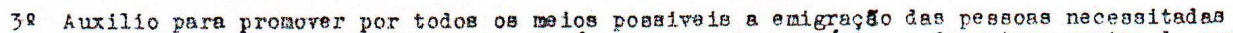

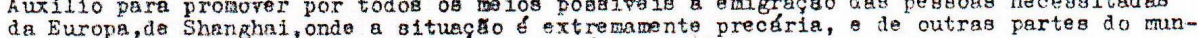
da Europa, de Shanghai, onde a situaço é extremamento preck

48 Remessa de vivera roupas pacotes individualo para os paiges nos quafo tais remesas a ace 1 tis.

52 Auxiliog pateriais e financeiros, a gerera atuslrente conseguidos atravez da "CAMPANHA S.O.S."

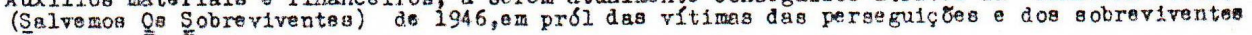
da guérra que perderam lares e havere desejem abendonar a Eurore.

Toda essa obra do "COMITÉ AUXHIAR DO "JOINT" de SEO Paulo é feita em colaboraço int ima com o "JOINT" ame ricano, que instelou suas flliais ns Europa, facliltando s8sim consideravelmente a realizacto do programs acima condensado em 5 pontos. O Comité celebrou sinda em junho deste ano um convénio com

Nos Estados Unidos o "JoINq" Jançou gua Poratdavol "Campanha de 50 milhós de dolares", enquadrad a na "Campanha de Cem Milhzes de Dolares" do "United Jeriah Appeal", em vista des somas enormes neossitades para

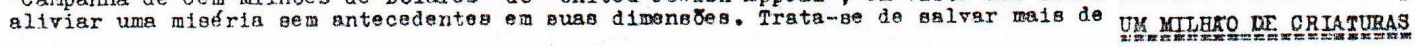

judias nqu-judjes que sobreviveram os horrores de Auschwitz, Maldenek, Dachau, Belsen, Buchenwald e outros campos da morte, que fugtrem da Europs orlentsl onde os pogroms tormaram 1mposeive I sus permanencia, quo

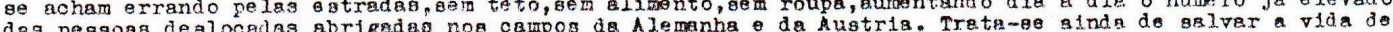
150.000 criancas.

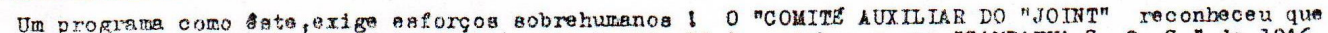

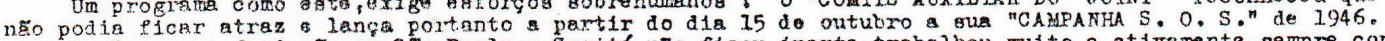

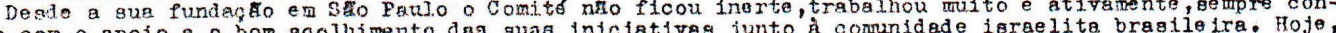
tando cor 0 gpolo o bom acolhimento das guas inielativas junto a conrunidade israelita brasile 1 ra. Hoje,

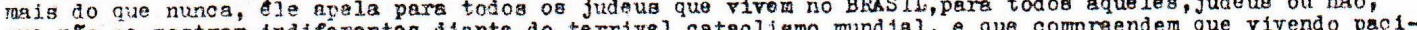
que nåo se mostram indiferentes diante do terrivel cataclismo mundial, e que compreendem que vivendo pact-

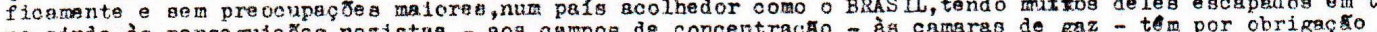

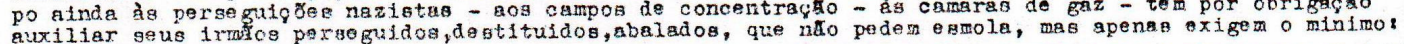
O DTREITO DE VIVER DECENTEMETIE; A OPORTUNIDADE DE GANHAR NO SUOR DO SEU ROSTO O FRO NOSSO DE CADA DIA; SEJA NA PALESTINA, NOS ESTALOS UNIDOS OU EM QUALQUER PAIS ONDE AINDA SE RESPTRA O AR PURO DA

L I B E R D A D :

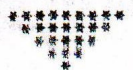

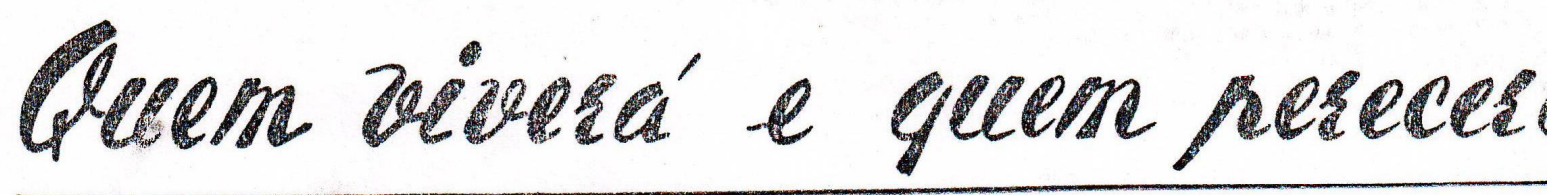

DEPENDE MAIS DO QUE NUNCA DE $\mathrm{V} O \mathrm{C}$ E $\$ \ldots \ldots \ldots \ldots \ldots \ldots \ldots$ MANDE A SUA CONTRIBUICEO AO "COMITE AUXIIIAR DO "J O I N T " DE SAO PAULO, DURANTE A "CAMPANHA S.O.S." DE 1946. AJUDE-O !

- Panfleto “O que é e o que faz o Comitê Auxiliar do JOINT de São Paulo”. São Paulo, 1946. Fundo 187/AHJB 
"1 $1^{\circ}$ Procura de pessoas deslocadas na Europa e de parentes de tais pessoas em outras partes do mundo;

$2^{\circ}$ Procura de famílias residentes no Brasil, a pedido das pessoas deslocadas;

$3^{\circ}$ Auxilio para promover por todos os meio possíveis a emigração das pessoas necessitadas da Europa, de Shangai, onde a situação é extremamente precária, e de outras partes do mundo onde a sobrevivência dessas pessoas não é garantida;

$4^{\circ}$ Remessa de víveres, roupas e pacotes individuais para os países nos quais tais remessas são aceitas;

$5^{\circ}$ Auxílios materiais e financeiros, a serem atualmente conseguidos através da "CAMPANHA S.O.S." (Salvemos os Sobreviventes) de 1946, em prol das vítimas das perseguições e dos sobreviventes da guerra que perderam lares e haveres e desejam abandonar a Europa.". ${ }^{240}$

As propostas de ação do Comitê Auxiliar esbarravam nas propostas da própria CIP. Não obstante ser fruto da Congregação, o Comitê constituía uma associação independente, mantendo um relacionamento em separado com o JOINT. Naquele momento, se as duas associações começassem a realizar campanhas para os mesmos fins e conquistassem o mesmo público, isso significaria para a mais antiga delas, a CIP, a perda de sócios, doações e prestígio. Diante disso, logo no início de 1946, surgiram as primeiras rusgas entre as duas organizações.

Em reunião entre a Diretoria da CIP e os membros do Comitê, Paulo Krumholz e Salo Wissmann, a Congregação alegou que o papel do Comitê deveria ser somente o da angariação de fundos e remessa dos mesmos para o além-mar. Segundo a CIP, a prestação de serviços em prol de pessoas físicas prejudicaria sua posição, além de contrariar os "princípios previamente estabelecidos para as atividades do Comitê, princípios esses que constam das declarações verbais feitas pelo sr. Resznick(...)”. 241 As objeções da CIP voltavam-se, principalmente, contra as atividades do Comitê no campo das chamadas, da procura de parentes e amigos, e do envio de pacotes particulares para a Europa e Palestina. Assim, a Congregação requeria exclusividade nas atividades que exigissem um relacionamento direto entre a associação e seus auxiliados.

Em resposta, Paulo Krumholz, um dos vice-presidentes do Comitê, esclarecia que o objetivo principal daquela instituição era o de arrecadar recursos e enviá-los para a Europa. No entanto, para que isso pudesse ocorrer, seria necessário que houvesse a promoção de campanhas efetivas de angariação de fundos, para as quais o contato com

\footnotetext{
${ }^{240}$ Panfleto O que é e o que faz o COMITÊ AUXILIAR do JOINT em São Paulo? São Paulo, 1946. Fundo 187/AHJB.

${ }^{241}$ Ata da Reunião da Diretoria e Presidentes das Comissões da Congregação Israelita Paulista. São Paulo, 21 de maio de 1946. Fundo 187/AHJB.
} 
os futuros contribuintes seria fundamental. ${ }^{242}$ Assim, o Comitê deveria fazer propaganda de suas ações para suscitar o interesse por parte dos judeus de São Paulo. Propunha-se, no entanto, a "colaborar com a CIP estreita e harmoniosamente". ${ }^{243}$ Ao final de uma longa discussão, os representantes de ambas as associações concluem por uma relação amistosa, já que, muitos representantes da CIP eram também membros do Comitê. Para a CIP, os principais pontos do armistício deveriam ser: evitar o trabalho "duplo e inútil, aconselhando-se unificar as listas do Comitê e da CIP"; e evitar que as relações da CIP com outras organizações estrangeiras fossem prejudicadas. Assim, o Comitê não deveria transmitir a idéia errônea de que seria a única instituição competente para a localização de pessoas na Europa ${ }^{244}$.

Resolvidos os problemas, restava agir. O Comitê iniciou suas atividades em 1946, encabeçando campanhas além-mar e coordenando todo o serviço de remessas de pacotes para o exterior. Rapidamente, direcionou suas atividades para o auxilio e salvamento dos judeus que haviam conseguido sobreviver ao Holocausto e, naquele momento, não possuíam mais suas casas, roupas, família e quaisquer meios de sobrevivência. Através de panfletos com fotografias e dizeres que atentavam para a miséria da comunidade judaica em outros países, o Comitê esperava arrecadar dinheiro, viveres, roupas, tecidos, calçados, alimentos e produtos de higiene, que seriam distribuídos em toda a Europa e Palestina com a ajuda do JOINT. Outras associações judaicas paulistanas e cariocas participavam também dessas campanhas que, já em 1946, conseguiram reunir um total de $\mathrm{Cr} \$ 1.596 .549,00$. Os pacotes angariados foram enviados para os escritórios JOINT em Paris, Varsóvia, Polônia, Alemanha e Viena, sendo compostos por: 3.082 metros de tecidos de lã; 8.700 metros dos aviamentos necessários para que o tecido fosse transformado em roupas; peças novas, como lençóis, cobertores, blusões, saias, blusas, meias e roupas brancas, num total de 34.960 quilos; 9.484 quilos de gordura; 5.920 quilos de carne bovina enlatada; 5.000 quilos de chocolate, além de caixas de papel higiênico, gazes e faixas de algodão e sapatos ${ }^{245}$.

\footnotetext{
${ }^{242}$ Ata da Reunião da Diretoria e Presidentes das Comissões da Congregação Israelita Paulista em conjunto com os representantes do Comitê Auxiliar do JOINT. São Paulo, 27 de junho de 1946. Fundo 187/AHJB.

${ }^{243}$ Idem.

244 Idem.

245 Boletim no. 3 da Campanha de 1946 do Comitê Auxiliar do JOINT. São Paulo, outubro de 1946. Fundo Alfred Hirschberg/AHJB.
} 


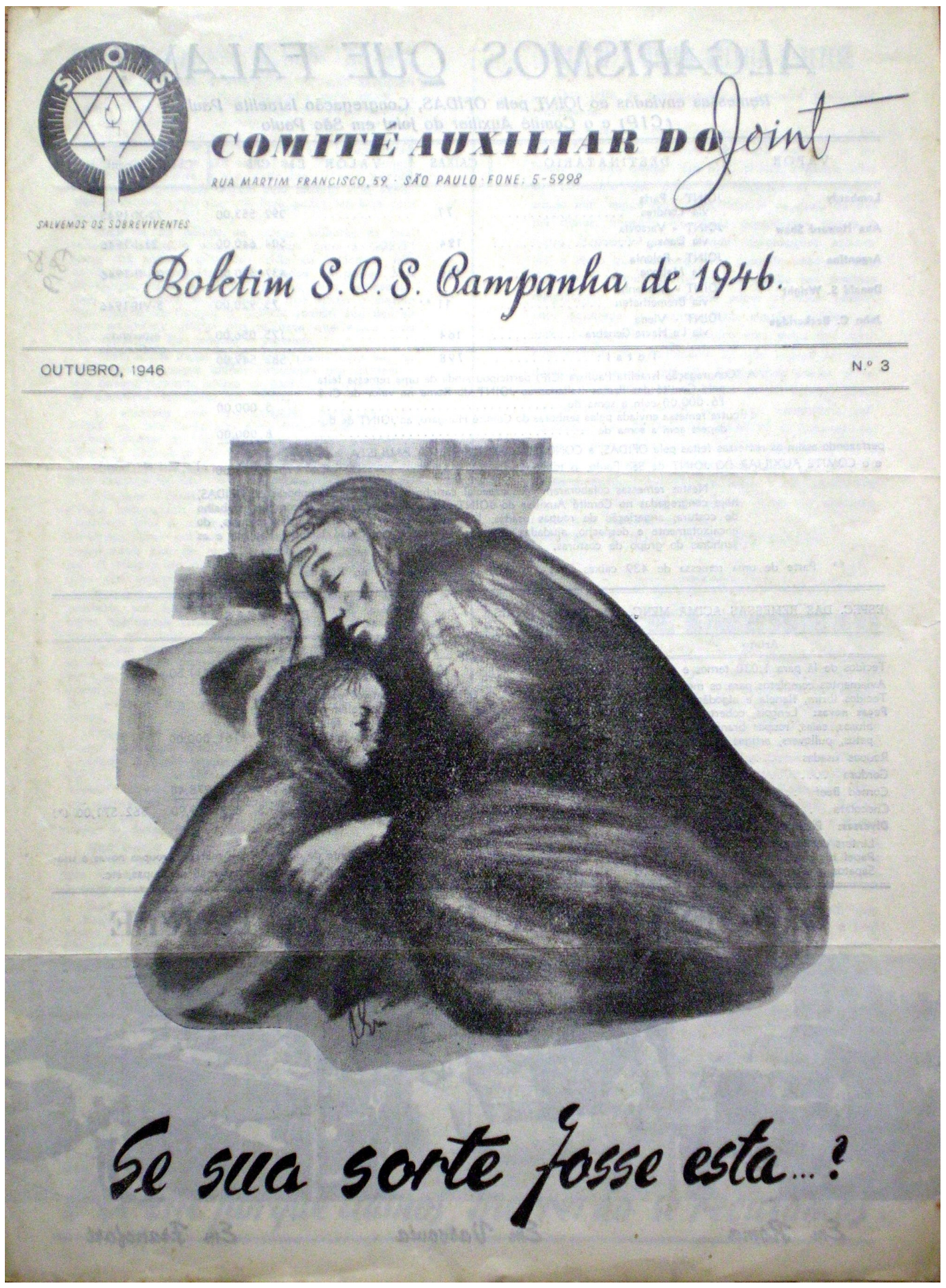

- Boletim n'. 3 "Se sua sorte fosse esta...?"da Campanha de 1946 do Comitê Auxiliar do JOINT. São Paulo, outubro de 1946. Fundo Alfred Hirschberg/AHJB. 
Mensalmente, o Comitê preparava e distribuía boletins e relatórios que serviam para explicar quais haviam sido as atividades do JOINT naquele período e, de que forma, o Comitê, através da comunidade judaico-paulistana, havia colaborado para atingir aqueles resultados e ajudar os sobreviventes e deslocados de guerra. Além disso, as publicações serviam para esclarecer e detalhar qual seria a situação real vivenciada pelos judeus na Europa, alegando que, diante de tamanho sofrimento, seria uma obrigação para a comunidade judaica brasileira ajudar aos seus companheiros:

"Mais de um milhão de judeus, milhares de pessoas deslocadas e sem teto olham para o 'JOINT' como sua última salvação. Não as podemos, não as devemos decepcionar (...). Todos nós, que vivemos num país que não experimentou em seu próprio solo os horrores bélicos, cujos habitantes viviam em plena segurança e sem temores, enquanto cidades da Europa se transformaram em cinzas e as vitimas inocentes do nazismo sucumbiram nos campos da morte ou erravam pelas estradas, devemos resgatar, com sacrifícios, a nossa própria existência, justificando-a, dando o máximo que podemos aos que necessitam desesperadamente. ${ }^{, 46}$

As capas dos boletins seguiam o padrão utilizado pelo JOINT em seus relatórios anuais, trazendo imagens e desenhos que instigavam a reflexão e despertavam a compaixão naqueles que os recebiam. Buscava-se criar a maior identificação possível entre os judeus de além-mar e aqueles já radicados no Brasil e, assim, levar uns a ajudar os outros como se esses fossem sua própria família, como se a existência de um estivesse atrelada totalmente à existência do outro.

Apesar de fundado entre o final de 1945 e inicio de 1946, portanto após o Estado Novo, o Comitê Auxiliar do JOINT não escapou à vigilância policial. A associação figura no dossiê DEOPS intitulado Sociedades Estrangeiras, no qual são investigados o Centro Hebreu de Socorro às Vítimas do Holocausto e a Sociedade Hebraica-Brasileira Renascença. A Polícia Política acreditava que tais associações estariam envolvidas na "formação de uma frente única judia na política de após-guerra"247, além do envio de remessas de dinheiro para o exterior, o que era considerado uma atitude estranha, e possivelmente subversiva. Considerando o caráter das associações investigadas, as acusações feitas seriam verdadeiras, sem, no entanto, podermos chamá-las de acusações.

\footnotetext{
246 Boletim n'. 3 "Se sua sorte fosse esta...?" da Campanha de 1946 do Comitê Auxiliar do JOINT. São Paulo, outubro de 1946. Fundo Alfred Hirschberg/AHJB.

${ }^{247}$ Relatório policial elaborado sobre uma carta de Buenos Aires para o Centro Hebreu de Socorro às Vítimas do Holocausto. São Paulo, junho de 1944. Dossiê n ${ }^{\circ} 50-J-67$ de Sociedades Estrangeiras. DEOPS/SP. APESP.
} 
A fim de legalizar o funcionamento da nova instituição, em julho de 1946, Horácio Lafer enviou ao DEOPS um memorandum, no qual explicitava os objetivos principais do recém constituído Comitê Auxiliar do JOINT:

\begin{abstract}
"Visando prestar aos israelitas vitimas da guerra na Europa, auxílio que torne possível a reconstrução de suas vidas e sua reabilitação moral e material, e cooperar igualmente com as entidades que se dedicam a esse mobilitante trabalho, um grupo de pessoas israelitas de São Paulo reuniu-se para formar um "Comitê Auxiliar do JOINT"

.As finalidades do trabalho que essas pessoas se propõe são de caráter humanitário e filantrópico, sem qualquer aspecto político. Pretendem elas prestar auxílios de toda a ordem aos israelitas vítimas da guerra (...) Igualmente pretendem estabelecer trabalho de procura de pessoas desaparecidas, que torne possível a reunião de famílias dispersas. E, finalmente, cooperarão no trabalho de emigração dessas vítimas, da Europa para outros países.

Reunindo aqui os recursos necessários para o seu trabalho, pretendem os promotores dessa obra de auxílio, fazer a remessa e a distribuição das contribuições recebidas por intermédio das várias organizações apolíticas de serviço social que se encontram aparelhadas para agir nos países devastados pela guerra, tais como a Cruz Vermelha, o American-Jewish JOINT Distribution Committe (que pode ser classificado como Cruz Vermelha Israelita), e outras entidades igualmente idôneas. Cooperando estreitamente com essas organizações (...) tal como a Hias-Hicem, é todavia intenção dos promotores desse trabalho organizar o 'Comitê' como associação civil brasileira, dando-lhe existência legal e, registrando-a nos departamentos competentes. Tratar-se-á, assim, de uma entidade brasileira absolutamente independente, embora colaborando em seu trabalho com as organizações de assistências existentes no exterior. "248
\end{abstract}

Eis aqui, a explicação em detalhes de quais seriam as atividades exercidas pelo Comitê, sem que houvesse nenhuma alusão a qualquer finalidade política. Num momento em que até mesmo o Partido Comunista estava "legalizado", qual seria o problema em autorizar o funcionamento de uma organização beneficente? Anexado ao memorandum encontramos um recorte do jornal $O$ Trabalho, de 13 de fevereiro de 1948, relatando a visita ao Brasil de Emanuel Borenstein, representante do JOINT novayorkino. Em cocktail patrocinado pelo Comitê Auxiliar do JOINT, Borenstein foi apresentado à imprensa paulista a fim de informar sobre o estabelecimento, em São Paulo, de "um escritório central do JOINT voltado para todo o país."249

Era comum a polícia anexar aos seus inquéritos quaisquer reportagens que pudessem introduzir novas informações acerca da pessoa ou instituição investigada. $O$ alvará de funcionamento do Comitê Auxiliar foi concedido, entretanto, em relatório de

\footnotetext{
${ }^{248}$ Memorandum de Horácio Lafer para o Departamento de Ordem Política e Social de São Paulo. São Paulo, 5 de julho de 1946. Dossiê $n^{\circ} 50-J-67$ de Sociedades Estrangeiras. DEOPS/SP. APESP.

${ }^{249}$ Jornal $O$ Trabalho de Sorocaba. Sorocaba, 13 de fevereiro de 1948. Dossiê n $n^{\circ} 50-J-67$, de Sociedades Estrangeiras. DEOPS/SP. APESP.
} 
novembro de 1947, essa mesma associação foi tida pela polícia como uma "sociedade de registro duvidoso". 250

Tanto a CIP, como o Comitê Representativo e o JOINT declaravam-se terminantemente anti-sionistas. Acreditavam que a comunidade judaica deveria se estabelecer e criar raízes naqueles países que os haviam acolhido, sem, no entanto, esquecerem-se de sua identidade judaica. Além disso, num momento em que ideologias políticas diferentes eram tidas pela policia com desconfiança, seria mais interessante àquelas associações manterem-se distantes de tais discussões.

Esse posicionamento apolítico não impediu, todavia, que essas instituições dedicassem uma parte de seu trabalho beneficente à comunidade judaica de Eretz Israel, sendo esta uma das muitas facetas do auxilio além-mar. Em 1945, em cooperação com a Agência Judaica para a Palestina, o JOINT utilizou parte dos recursos arrecadados em campanhas na América Latina, para financiar o transporte de mais de 8.000 judeus da Europa para a Palestina. Além disso, administrou cursos vocacionais de treinamento agrícola a milhares de jovens, subvencionou mais de setenta instituições educacionais e forneceu alimentação suplementar a diversas crianças e adolescentes subnutridos. ${ }^{251}$ Nesse mesmo ano, a CIP uniu-se ao Centro Hebreu Brasileiro de Socorro às Vítimas do Holocausto, instituição de cunho sionista, para angariar fundos em prol de Keren Hajessod. $^{252}$

O envio de recursos e mantimentos para a Palestina intensificou-se em 1948, após a formação do Estado de Israel. Em união com o governo de Israel, o JOINT passou a despender parte dos recursos que recebia com a recém-criada associação Malben, responsável por ajudar imigrantes doentes, com qualquer tipo de deficiência física ou mental, e os idosos. Três anos após a sua criação, o Malben tornou-se um dos departamentos mais importantes do JOINT, devendo todo o seu financiamento àquela instituição. Nesses anos, foi o responsável por ajudar mais de 24.000 imigrantes, construiu casas, hospitais e abrigos, além de instalar um programa médico contra a disseminação de doenças comuns, como a tuberculose. ${ }^{253}$

\footnotetext{
${ }^{250}$ Relatório do Departamento de Segurança Política e Social de São Paulo. São Paulo, 12 de novembro de 1947. Dossiê n'50-J-67, de Sociedades Estrangeiras. DEOPS/SP. APESP.

${ }^{251}$ Para que tornem a viver. Relatório Anual de 1945 do JOINT Distribution Committee. Fundo Alfred Hirschberg/AHJB.

${ }^{252}$ Ata da Reunião da Diretoria da Congregação Israelita Paulista. São Paulo, 12 de junho de 1945. Fundo 187/AHJB.

${ }^{253}$ The JDC Story, 1914-1952, por Moses A. Leavit, Vice- Presidente Executivo do JOINT Distribution Committee. Fundo Alfred Hirschberg/AHJB.
} 
Não obstante, a relação entre os Comitês do JOINT e as associações sionistas não eram tão amistosas. Enquanto o JOINT acreditava na continuidade do auxilio aos judeus vitimas na Europa e em sua imigração para os países do continente americano, os grupos sionistas defendiam que todo e qualquer recurso disposto pela comunidade judaica mundial deveria ser direcionado ao recém criado Estado de Israel. Investir na ajuda aos que estavam na Europa seria, pois, incorrer em desperdício. Essa disputa ficou clara durante a Campanha de arrecadação de fundos do Comitê JOINT paulistano em 1948.

Desde o ano anterior, em 1947, já se faziam sentir rusgas entre o Comitê JOINT paulistano e o American JOINT Distribution Committee, causadas, principalmente, pela expansão da ideologia sionista entre a comunidade judaica de São Paulo. A demora e a falta de entusiasmo dos membros do Comitê paulistano em relação aos trabalhos de arrecadação de fundos, para aquele ano, levaram a Oficina Latino-americana do JOINT a exprimir duras criticas àquela organização:

"Os primeiros contatos individuais e em conjunto com membros do Comitê Auxiliar do JOINT em São Paulo, nos deram a impressão de que este Comitê é praticamente inexistente como grupo de pessoas unificadas no propósito de cooperar com o JOINT dentro da linha geral de sua orientação e seu programa." 254

Para o JOINT, a campanha paulistana de 1947 deveria arrecadar recursos exclusivamente para os escritórios centrais daquela associação. Deveria ser uma empreitada voltada para o JOINT e não uma campanha unificada como fora proposto pelo Comitê paulistano. Por seu lado, esse comitê encontrava-se numa situação complicada: nenhum representante do JOINT aceitara vir a São Paulo e ajudar na propaganda para a arrecadação de fundos; além disso, o aumento dos adeptos ao sionismo provocara uma cisão no seio da comunidade judaico-paulistana e, aqueles que antes doavam ao Comitê JOINT, preferiam agora doar às instituições sionistas. Entre os próprios diretores do Comitê paulistano havia aqueles que simpatizavam com a causa sionista.

\footnotetext{
254 "Los primeros contatos individuales y en conjunto con miembros del Comitê Auxiliar do JOINT em São Paulo, nos dieron la impresión de que tal Comitê es practicamente inexistente como grupación de personas unificadas en el propósito de cooperar con el JOINT dentro del lineamento general de su orientación y su programa." Relatório "En redor a la proyectada United Jewish Appeal em São Paulo", de T. Berelejis, Oficina Latinoamericana del JDC. São Paulo, 8 de fevereiro de 1948. Fundo Ludwig Lorch, LEER-USP.
} 
Diante de tal situação, o meio pelo qual o Comitê esperava arrecadar algum dinheiro era através de um apelo unificado, contando com associações judaicopaulistanas de diferentes credos e ideologias. Esperavam que, desse modo, toda a comunidade se sentisse disposta a colaborar. No entanto, o prestigio sionista os levou a requerer mais de $50 \%$ do total da quantia arrecadada, o que aborreceu o escritório latino-americano do JOINT, para o qual seriam revertidos, apenas, $20 \%$ das contribuições. ${ }^{255}$ A percentagem restante seria dividida entre as principais associações locais.

Essa situação provocou a visita de T. Berelejis que, em nome da Oficina Latinoamericana do JDC, reuniu-se com representantes das principais associações judaicopaulistanas a fim de entrar num consenso e aumentar a porcentagem de doações destinadas ao JOINT. Seu argumento principal baseava-se no fato de que grande parte dos recursos à disposição do JOINT acabava sendo empregado em trabalhos na Palestina, convergindo, pois, com os anseios dos núcleos sionistas. Todavia, após vários dias de discussão o problema não fora resolvido e o JOINT percebeu que seria necessário reorganizar seu Comitê em São Paulo. Ludwig Lorch reassumiria, no ano seguinte, uma das posições na diretoria daquela organização.

Recém-chegado de uma viagem através da Europa, Ludwig Lorch havia visitado os mais importantes escritórios do JOINT e acompanhado de perto como eram realizados os seus trabalhos. Visitara também os campos de deslocados de guerra nos quais viviam inúmeros judeus "em situação de miséria, doenças e desespero (...) aguardando o auxilio do JOINT com que contam desesperadamente”. 256 Para aquele ano de 1948, o Comitê decidiu organizar em todo o Estado de São Paulo uma campanha de arrecadação de fundos com inicio em setembro. Essa idéia, porém, esbarrou nas pretensões sionistas e na apatia da coletividade judaico-brasileira, ambas denunciadas por Ludwig Lorch:

"Com número de cerca de 40000 israelitas no Estado e na cidade de São Paulo o JOINT poderia receber um forte apoio moral e material, devia por uma campanha anual recolher 5.000.000 Cr. ou 200.000 US\$. (...) Embora tivesse sido fundado em 1946 um Comité Auxiliar do JOINT em S. Paulo e em fevereiro de 48 um escritório do American J.D. Committee não foi possível a mobilização da coletividade israelita em favor do JOINT e peor - parece que o JOINT está se tornando cada vez menos popular quer

\footnotetext{
${ }^{255}$ Relatório "En redor a la proyectada United Jewish Appeal em São Paulo”, de T. Berelejis, Oficina Latinoamericana del JDC. São Paulo, 8 de fevereiro de 1948. Fundo Ludwig Lorch, LEER-USP.

${ }^{256}$ Ata da Reunião do Comitê Auxiliar do JOINT de São Paulo. São Paulo, 13 de julho de 1948. Fundo Ludwig Lorch, LEER-USP.
} 
dizer: a pouca cooperação está diminuindo ainda mais. (...) À base da questão acha-se o fanatismo nacionalista dos grupos W.J.C. e de certos líderes do movimento sionista. As dificuldades criadas não provêm tanto de uma inimizade ao trabalho do JDC como do fanatismo pela própria causa nacionalista que reclama para seu movimento a totalidade das forças espirituais e materiais." 257

Segundo Lorch, existiria um grupo de "fanáticos contra-jointistas" empreendendo contra o JOINT um movimento de resistência passiva, obstrução e sabotagem. Diante desse quadro de contra-propaganda e falta de cooperação, restaria àquela organização três caminhos possíveis: continuar a realizar o seu trabalho independentemente da boa vontade e cooperação dos grupos antagonistas; continuar o seu trabalho nas condições atuais, o que resultaria em diminuição de suas forças, desperdício do trabalho dos colaboradores e perda de pessoas dispostas a ajudar de modo efetivo; ou, por último, deixar de existir por completo. ${ }^{258}$ Ignorando as ameaças e a falta de auxilio por parte dos sionistas, Lorch levou a Campanha de 1948 ao interior do Estado de São Paulo. ${ }^{259}$

Eram poucas as famílias judias vivendo no interior do estado: havia 15 famílias em Piracicaba; 7 em Rio Claro; 10 em São Carlos; 11 em Araraquara; 9 em Ribeirão Preto e 12 em Catanduva. Representando o Comitê paulistano, Harry Calmnovitz visitou as referidas cidades, procurou reunir todas aquelas famílias, expôs os objetivos da campanha através de palestras e filmes e, por último, esquematizou um mini-comitê local, escolhendo representantes que seriam os responsáveis por fazer a arrecadação dos fundos. Ao final de todo esse trabalho, apesar de algumas comunidades terem se recusado a participar, alegando que já haviam feito campanhas próprias naquele ano, presumiu-se que os recursos a serem recebidos totalizariam $\mathrm{Cr} \$ 90.300,00$, quantia muito aquém do total esperado por Ludwig Lorch.

\section{2 - O JOINT, a Congregação Israelita Paulista e os Emigrantes}

Entre 1936 e 1938, a imigração judaica para o Brasil foi realizada, principalmente, através das cartas de chamada, já citadas anteriormente. O início da Segunda Grande Guerra, em 1939, provocou o aumento do número de emigrantes

\footnotetext{
${ }^{257}$ Rascunho de um relatório de Ludwig Lorch a respeito da situação do "JOINT" em São Paulo. São Paulo, s/d. Fundo Ludwig Lorch, LEER-USP.

${ }^{258}$ Idem.

${ }^{259}$ Relatório “Cidades Visitadas”. Campanha Pró-sobreviventes JOINT-HIAS-ORT-OSE. São Paulo, 29 de novembro de 1948. Fundo Ludwig Lorch, LEER-USP.
} 
judeus na Europa, ao mesmo tempo em que leis impostas pelo regime hitlerista dificultavam a saída dessas pessoas dos territórios ocupados pelo nazi-fascismo. Não obstante, a nova legislação brasileira, imposta pela Constituição de 1937, buscava restringir a entrada de determinados núcleos imigrantes no Brasil, dentre os quais estavam os refugiados judeus.

Nesse contexto, a interação entre a Congregação Israelita Paulista e o JOINT visava encontrar brechas em meio àquela situação, a fim de imigrar para o Brasil o maior número possível de vítimas. Em 1939, Ludwig Lorch expôs ao Presidente do JOINT quais medidas, em sua opinião, deveriam ser tomadas para a imigração de judeus ao Brasil:

"O Hicem, para um futuro próximo, deve articular o trabalho de envio de refugiados ao Brasil e cuidar deles desde sua chegada até o momento em que os mesmos alcancem seu destino final no país (...). A fim de acelerar o desenvolvimento de assentamentos agrícolas, esses deverão ter lugar sob a responsabilidade de uma Corporação Brasileira (...). A Corporação Brasileira deve, no inicio, conseguir o titulo da fazenda Rezende, e de qualquer outra propriedade que se faça necessária adquirir no futuro. (...) A preferência deve ser dada aos assentamentos agrícolas em diferença aos negócios ou ao comércio." 260

A organização HICEM, citada por Lorch, fora fundada em 1927 com o objetivo de ajudar os judeus da Europa a emigrar. Na origem de sua fundação encontramos três, dentre as maiores associações beneficentes judaicas da época: a HIAS (Hebrew Immigrant Aid Society), cuja sede estava estabelecida em Nova York; a ICA (Jewish Colonization Association), sediada em Paris, e a Emigdirect, uma organização voltada para a emigração com sede em Berlim. No momento em que a Segunda Guerra Mundial começou, o HICEM possuía escritórios por toda a Europa e Américas do Norte, Sul e Central. Seu "quartel-general" estava baseado em Paris, uma das primeiras localidades que sucumbiram ao poder do exército nazista. Deste modo, em 1940, o Hicem transferiu suas atividades para Lisboa, já que Portugal era um dos únicos países neutros da Europa. Desta forma, aproximava-se cada vez mais do JOINT. Ao final desse mesmo

\footnotetext{
260 "The Hicem for the immediate future should handle the work of sending refugees to Brazil, and of taking care of them on arrival and until such time as they reach their final destination in Brazil. (...) In order to speed up the development of agricultural settlements should be placed in charge of a Brazilian corporation (...) The Brazilian corporation should, as a start, take title to the Rezende Farm, and to any other property that it might be necessary to acquire in the future(...). Preference should be given to agricultural settlements as distinguished from business or comerce". Carta de Ludwig Lorch para Paul Baerwald, Presidente do American Jewish JOINT Distribution Committee, Cidade de Nova York. São Paulo, 19 de maio de 1939. Fundo Ludwig Lorch, LEER-USP.
} 
ano, grande parte das necessidades financeiras do Hicem era suprida por aquela associação.

A ICA havia fundado no Brasil, em 1904, mais precisamente no Estado do Rio Grande do Sul, as primeiras colônias agrícolas voltadas para receber e assentar os imigrantes judeus provenientes do Império Russo. O sucesso desse trabalho levou o HICEM a propor, em 1936, um novo projeto nos mesmos moldes dos anteriores, porém, voltado aos imigrantes judeu-alemães refugiados do nazismo no Brasil. Nesse contexto, surgiu a idéia de formar a colônia de Rezende, citada por Ludwig Lorch em sua carta. Naquele momento, agravavam-se as dificuldades para legalizar a situação de judeus recém-chegados ao Brasil e conseguir vistos para novos imigrantes. Ao mesmo tempo em que as autoridades e diplomatas do governo Vargas endureciam seus discursos em prol da instalação dos novos imigrantes no campo, crescia na Europa a demanda pela emigração por parte da comunidade judaica mais citadina, ligada à indústria e ao comércio europeus.

O Decreto-lei $\mathrm{n}^{\circ}$. 406, instituído em maio de 1938, explicitava qual era o tipo de imigrante ideal desejado pelo governo brasileiro:

Art. 16. Oitenta por cento $(80 \%)$ de cada quota serão destinados a estrangeiros agricultores ou técnicos de indústrias rurais.

Art. 17. O agricultor ou técnico de indústria rural não poderá abandonar a profissão durante o período de quatro (4) anos consecutivos, contados da data do seu desembarque.

Art. 18. Quando entender conveniente as necessidades econômicas do País, o Conselho de Imigração e Colonização poderá permitir que o saldo das quotas seja aproveitado na introdução de agricultores de nacionalidade, cuja quota já se tenha esgotado.

Durante o regime hitlerista, um dos principais objetivos da CIP era o de promover a imigração do maior número possível de judeus para o Brasil. Conhecendo os critérios impostos pela legislação imigratória federal, a CIP concluíra que seria uma estratégia interessante utilizar o subterfúgio de uma colônia agrícola para facilitar a concessão de vistos aos judeus:

\footnotetext{
"Seguem diversas propostas relativamente à hospidalização dos recém-chegados. O Snr. Gruenebaum pensa em uma fazenda para a formação de agricultores (...) O Snr. Wissman responde que por enquanto não se deixa entrar agricultores judeus, sendo que nem a Ica conseguiu possibilitar a entrada de agricultores judeus, munidos de um atestado do Ministério da Agricultura de Berlim." 261
}

\footnotetext{
${ }^{261}$ Protocolo da Sessão da Assembléia dos Representantes da Congregação Israelita Paulista. São Paulo, 29 de janeiro de 1939. Fundo 187/AHJB.
} 
Em 1939, momento no qual o salvamento das vítimas da Segunda Guerra Mundial constituía uma das principais missões da comunidade judaico-paulistana, a CIP desconhecia o caminho a seguir a fim de imigrar os judeus para o Brasil. Sabiam que a legislação brasileira resguardava $80 \%$ das cotas de imigração para agricultores e técnicos agrícolas e, assim, chamavam a atenção para a "necessidade de transformar nossa gente em lavradores e agricultores $(. . .)^{262}$ ". No entanto, ignoravam que, para o governo brasileiro, agricultores e agricultores judeus compunham duas categorias de imigrantes completamente diferentes. Além disso, os judeus refugiados do regime nazifascista apresentavam características diferentes daqueles que anteriormente haviam imigrado para o Brasil, provenientes do Leste europeu. Expulsos de seu país de origem e espoliados de seus direitos materiais e políticos, desesperavam-se ao saber que a condição para recomeçar em um novo país seria o assentamento em espaços agrícolas, com os quais, não estavam acostumados. Deste modo, a formação de uma colônia agrícola em Rezende fracassou.

Ciente das restrições impostas à imigração por diversos países americanos e dos subterfúgios anti-semitas utilizados por muitos desses governos, o JOINT procurava preparar-se para os dias difíceis que ainda viriam:

\begin{abstract}
"Eu serei grato a você se você gentilmente me relatar assim que puder sobre todos os emigrantes que chegaram ao seu país desde 1933 e que possuem qualquer registro criminal. (...) Por favor, permita-me saber o nome das pessoas que se enquadram nessa categoria, data e cidade de nascimento, residência antes de imigrar ao seu país, e as acusações que trazem contra si. Este material será usado somente para meu registro estritamente confidencial, mas eu considero importante estar equipado com todos esses fatos no caso do surgimento de algum argumento anti-semita relacionado ao Hemisfério Ocidental." 263
\end{abstract}

A comunidade judaica buscava, pois, defender-se de possíveis acusações acerca de seu caráter e atuação nos países para os quais imigravam. No caso brasileiro, seria difícil para Ludwig Lorch fazer um levantamento acerca de todos os imigrantes que possuíssem qualquer histórico criminal, já que, naquele momento, a polícia comandada por Getúlio Vargas empenhava-se em perseguir e vigiar quaisquer elementos

\footnotetext{
${ }^{262}$ Idem.

263 "I should be grateful to you if you would kindly report to me at your earliest convenience about all emigrants who came to your country since 1933 and who have any criminal record (...) Please let me know the name of persons who fall under that category, date and city of birth, residence before immigration to your country, and the charge brought against them. This material will be used only for my very confidential record but I consider it important to be equipped with all these facts in case anti-alien arguments should come up pertaining to the Western Hemisphere." Carta de Frederick W. Borchard, para Ludwig Lorch c/o para American Jewish JOINT Distribution Committee, Cidade de Nova York. Nova York, 15 de setembro de 1941. Fundo Ludwig Lorch, LEER-USP.
} 
"alienígenas" presentes na sociedade brasileira. Em posse desses dados, o JOINT poderia rebater possíveis acusações direcionadas aos judeus e tentar o deferimento do maior número possível de vistos junto aos consulados americanos na Europa.

Vários historiadores têm buscado compreender os motivos que provocaram essa reação negativa em relação a algumas categorias de imigrantes, por parte de países do continente americano, durante e após a Segunda Guerra Mundial. Em sua publicação mais recente, Maria Luiza Tucci Carneiro compilou textos de diversos estudiosos sobre o assunto a fim de relacionar e explicar as políticas assumidas por esses países em relação à imigração judaica para as Américas e, em especial, frente aos refugiados do nazismo ${ }^{264}$.

A tentativa de resgatar e conseguir vistos para os refugiados emigrarem ocupou um grande espaço na correspondência entre CIP e JOINT. Ser refugiado e, como tal, conseguir ingressar no Brasil era uma tarefa difícil: primeiro porque todo o processo da viagem dependia da boa-vontade de outros países pelos quais os refugiados teriam de transitar; em segundo, porque os consulados brasileiros não facilitavam a concessão de vistos, tendo em vista as restrições impostas pelas circulares secretas. Entre 1937 e 1948, segundo levantamento realizado por Tucci Carneiro, foram editadas 23 circulares secretas de teor anti-semita ${ }^{265}$. A somatória desses fatores resultou na constante peregrinação dos refugiados através dos consulados europeus em busca de vistos para qualquer país.

A historiografia atual tem se debruçado sobre as dificuldades e os percalços enfrentados pelos judeus, principalmente no período da Segunda Guerra Mundial, na tentativa de conseguir imigrar ao Brasil. A política anti-semita empreendida pelo governo de Getúlio Vargas (1930-1945) foi amplamente explorada em trabalhos como o de Maria Luiza Tucci Carneiro, Avraham Milgran e Fábio Koifman, já citados aqui. No entanto, a continuidade dessa política ao longo do governo de Eurico Gaspar Dutra (1946-1950) ainda está para ser estudado. Destaco, nesse aspecto a obra de Leonardo Senkman ${ }^{266}$, elucidativa acerca da continuidade de traços anti-semitas na política imigratória brasileira até o segundo governo Vargas (1951-1954).

\footnotetext{
${ }^{264}$ Maria Luiza Tucci Carneiro (org.). O Anti-semitismo nas Américas. São Paulo, Edusp, 2007.

${ }^{265}$ Maria Luiza Tucci Carneiro. $O$ Veneno da Serpente, Op.cit.

266 Leonardo Senkman. "A Questão Judaica na Argentina e no Brasil: A Contraditória Lógica de Inclusão/Exclusão do Populismo sob Vargas e Perón”. In: Maria Luiza Tucci Carneiro (org.) O Antisemitismo nas Américas, Op.cit.
} 
Ao final da Segunda Guerra Mundial, em 1945, acentuou-se na Europa o fenômeno das Displaced Persons, vítimas do conflito que haviam perdido suas casas e seus familiares, não tendo, pois, uma pátria para retornar. Dentre estes, havia milhares de sobreviventes do Holocausto que, sem família e documentos de identificação, debilitados e traumatizados, aguardavam por socorro. Iniciou-se assim, uma grande campanha coordenada pelas associações judaicas internacionais, como o JOINT e a HICEM, em busca de parcerias de outras entidades judaicas a fim de localizar parentes e amigos das vítimas e um lugar para que as mesmas pudessem recomeçar suas vidas. Entretanto, mesmo após o governo Vargas, o Estado não suprimiu as restrições à imigração judaica. Segundo Tucci Carneiro, "simultaneamente ao aparecimento físico deste 'ser deslocado', os governos intolerantes acionaram estereótipos e metáforas de forma a inseri-lo no discurso anti-semita em circulação" ${ }^{\text {267 }}$. Em Veneno da Serpente, a autora reproduz alguns trechos de um artigo de Geraldo de Menezes Cortes, publicado em março de 1947, pela Revista de Imigração e Colonização:

“(...) Pelas informações já colhidas, há entre eles elementos perturbadores do equilíbrio social; há 'desajustados do trabalho!', gente que perdeu o hábito de labutar (...) há os judeus que se acham obcecados pelos problemas da Palestina e cujo valor econômicosocial é de forma a não se recomendarem à nossa corrente imigratória (não se trata do odioso preconceito racial dos nazistas mas da defesa dos nossos interesses econômicos.....",268

A idéia de que o refugiado seria um "peso morto" para a economia do país era difundida entre os ideólogos da época, como pudemos constatar no texto de Menezes Cortes. Interessante salientar que, na tentativa de imigrar parentes e amigos para o Brasil, muitos judeus enviavam atestados de trabalho para os consulados brasileiros na Europa, como forma de comprovar que o candidato ao visto teria como se sustentar no país receptor. No entanto, em muitos casos, tais documentos não garantiam a concessão de um visto. Percebe-se que as exigências de adaptabilidade econômica funcionavam como um subterfúgio para o motivo real de uma política intolerante e seletiva baseada em critérios étnicos.

Leonardo Senkman afirma que, apesar de pró-Estados Unidos, o regime dito “democrático" de Dutra rejeitou os sobreviventes judeus e aceitou, como imigrantes, os colaboracionistas do nazismo. Esta mesma posição é sustentada por Tucci Carneiro

\footnotetext{
${ }^{267}$ Maria Luiza Tucci Carneiro. Cidadão do Mundo: Brasil e a Questão dos Refugiados Judeus (19331948), p. 441.

${ }^{268}$ Maria Luiza Tucci Carneiro. Veneno da Serpente, Op.cit, p.156.
} 
como um dos primeiros resultados de sua pesquisa "Missionários do Reich", no qual a autora analisa a presença dos nazistas no Brasil e a atuação de alemães imigrantes radicados no Brasil e seus descendente durante a Segunda Guerra Mundial. ${ }^{269}$ Dutra deu continuidade à política imigratória seletiva, investindo na incorporação de operários para a indústria e de trabalhadores para o campo. Nesse contexto, o governo "selecionava mão-de-obra de países etnicamente latinos e católicos como Itália, Portugal e Espanha, com a finalidade de velar pela composição étnica de uma população nacional facilmente assimilável." ${ }^{270}$. Concluímos, pois, que mesmo após o conhecimento do Holocausto e da tragédia humana que esse representou na vida de milhões de judeus, as propostas anti-semitas defendidas por burocratas varguistas, continuavam a ser praticadas pelo governo federal. Em seu artigo, Senkman comenta um informe confidencial, de um embaixador brasileiro em Washington para o Ministro de Relações Exteriores, no qual eram citadas instruções sobre a imigração judaica que haviam sido dadas pelo próprio General Dutra "no sentido de afastar, em torno desta imigração, quaisquer possibilidades de negociações" ${ }^{271}$.

Do mesmo modo que Getúlio Vargas, Dutra defendeu sua posição sob a "desculpa" de que países como os Estados Unidos, também adotavam medidas restritivas contra a imigração de certas raças e, que, sua intenção seria apenas a de priorizar a imigração de agricultores para o Brasil.

Em 1947, Leni Cahn, Chefe de Emigração do Comitê JOINT de Berlim, levou ao conhecimento de todas as outras filiais daquela associação, o teor de sua conversa com a Missão Diplomática brasileira do local: “(...) nós fomos informados que a Missão ainda não recebeu as esperadas novas instruções a respeito da imigração e que oficialmente a imigração para o Brasil está fechada"272. Oficialmente a imigração para o Brasil estava fechada, porém, seria possível conseguir que o Ministério das Relações Exteriores estudasse casos individuais e autorizasse a diplomacia, em missão no exterior, a conceder vistos. Para isso, era necessário ter parentes no Brasil dispostos a

\footnotetext{
${ }^{269}$ Maria Luiza Tucci Carneiro. Missionários do Reich. A Presença de Nazistas no Brasil (1932-1978). Projeto de Pesquisa, Edital Universal CNPQ, 2005-2008.

${ }^{270}$ Leonardo Senkman. "La Política Imigratoria del Primer Peronismo Respecto de Los Refugiados de La Postguerra: Uma Perspectiva Comparada com Brasil, 1945-1954”. In: Gurevich, Beatriz; Escude, Carlos (org.). El Genocídio Ante la Historia y la Natureza Humana. Buenos Aires, Grupo Editor Latinoamericano S.R.L., 1994, p. 267.

${ }^{271}$ Leonardo Senkman não citou em seu artigo o nome do referido embaixador. Idem. p. 270

272 "“...) we were informed that the Mission had not yet receveid the expected now instructions regarding immigration and that officially 'immigration to Brazil is closed". Carta de Leni Cahn, Chefe do Departamento de Emigração do Comitê JOINT de Berlim, para o Comitê Auxiliar do JOINT de São Paulo. Berlim, 18 de julho de 1947. Fundo 187/AHJB.
} 
entrar em contato com os órgãos competentes do governo comprovando estar em situação legal no país, ter residência fixa e condições de arcar com todas as despesas do imigrante.

A correspondência trocada entre membros da comunidade judaico-paulistana e a comunidade judaico-carioca, leva-nos a crer que a coletividade, apesar de ter conhecimento das medidas restritivas, acreditava na chegada de "dias melhores". Em Circular Reservada $n^{\circ} 589$ de $1^{\circ}$ de fevereiro de 1948, o Ministérios das Relações Exteriores autorizava a concessão de vistos a todos os imigrantes, com exceção de mães viúvas, pais maiores de sessenta anos, filhos menores, tutelados, órfãos e filhas solteiras, aos quais caberia solicitar uma autorização especial. Um informe da CIP de 21 de outubro de 1948 demonstra que a Circular $n^{\circ} .589$ foi recebida com alegria:

"O Ministério das Relações Exteriores, ouvido antes do Conselho de Imigração e Colonização, expediu a circular, de $\mathrm{n}^{\circ} .589$ na qual se recomenda às Missões Diplomáticas e aos Consulados de carreira e privativos que facilitem, tanto quanto possível, a entrada de imigrantes no Brasil.

Ficou estabelecido, para a concessão de vistos permanentes, um critério uniforme segundo o qual todo individuo de ambos os sexos, entre 18 e 60 anos de boa saúde, boa conduta, sem antecedentes penais, não prejudicial à ordem pública, à segurança nacional e à integridade do regime, e que interesse à composição étnica da população brasileira, é um imigrante útil ao Brasil",273

Acreditando não serem "prejudiciais à ordem pública", e achando-se “interessantes à composição étnica brasileira”, a comunidade judaica acreditou que tal circular poderia favorecê-los, possibilitando a entrada no Brasil de seus parentes e amigos ainda sem destino na Europa. Em março de 1948, outra circular viria complementar a anterior, afirmando que “(...) os estrangeiros que tencionem vir ao ou para o Brasil, devem dirigir-se pessoal e diretamente, às repartições consulares e solicitar-lhes os vistos necessários, que não dependem de autorização individual do Ministério das Relações Exteriores(...)"274. A autorização individual era exigida somente aos "técnicos e professores contratados, e parentes", aos quais caberia “apenas, habilitar a Divisão de Passaportes do Ministério das Relações Exteriores a comunicar às repartições competentes que foi assegurada a subsistência de um

\footnotetext{
${ }^{273}$ Informe da Congregação Israelita Paulista. São Paulo, 21 de outubro de 1948. Fundo 187/AHJB. Grifo nosso.

${ }^{274}$ Diário Oficial de 12 de março de 1948. Carta de Tadeusz Lurie, Secretário Geral do Comitê Auxiliar do JOINT do Rio de Janeiro, para J. Sachs, Diretor Executivo do Comitê Auxiliar do JOINT de São Paulo. Rio de Janeiro, 16 de maio de 1949. Fundo 187/AHJB.
} 
determinado imigrante(...),275. Ou seja, segundo a circular, o pedido de visto para o Brasil passava a ser um processo simples, cujo deferimento, na maioria dos casos, caberia unicamente ao cônsul brasileiro em missão no país de emigração.

A esperança de dias melhores desfez-se aos poucos, ao longo dos anos de $1948 \mathrm{e}$ 1949, considerando-se o contingente de vistos indeferidos por cônsules brasileiros no exterior. Ao final de 1948, o Comitê auxiliar paulistano não conseguia entender por que os Comitês europeus não estavam utilizando a Circular $n^{\circ} .589$ para tentar ampliar a concessão de vistos brasileiros permanentes aos judeus. Em resposta, o Comitê JOINT de Paris elucidou que a verdadeira intenção presente naquela disposição seria afastar do Brasil indivíduos cuja etnia não fosse interessante para a composição de sua população, o que era entendido por muitos cônsules brasileiros como uma ordem para não emitir vistos aos judeus:

"Nós lamentamos informar-lhe que as possibilidades de obtenção de tais vistos não parecem ter aumentando para os nossos emigrantes, desde que um trecho dessa circular referente aos 'elementos não interessantes do ponto de vista da composição étnica da população brasileira' pode ser e é considerado pelo cônsul daqui como dedicado aos Judeus"276

Meses depois, em 1949, J. Sachs, representante do JOINT junto às Associações Israelitas de São Paulo, em carta para o Comitê Auxiliar do JOINT do Rio de Janeiro declarou não entender por que vistos de emigração para o Brasil não estavam sendo concedidos por algumas missões brasileiras no exterior:

"ultimamente temos recebido dos nossos escritórios da Europa, informações de que vários cônsules recusam-se a conceder vistos de emigração alegando que é necessários o recebimento de autorização por parte do Ministério, ação essa, completamente contraditória à referida circular"277.

Constatamos que, nestes tempos sombrios, formou-se uma rede de comunicação entre as várias comunidades judaicas da Europa e das Américas. No caso do Brasil, foram intensos os laços de solidariedade entre a comunidade carioca e a coletividade

\footnotetext{
${ }^{275}$ Idem. Fundo 187/AHJB.

276 "We regret to inform you that the prospects for obtention of such visas do not appear to have improved for our emigrants, since a passage from that circular referring to 'uninteresting elements from the point of view of the ethnic composition of the Brazilian population' may be and is considered by the consul here as applying to Jews." Carta de Nelly Bondy, em nome do Comitê Auxiliar do JOINT de Paris, para o Comitê Auxiliar do JOINT de São Paulo. Paris, 25 de novembro de 1948. Fundo 187/AHJB.

${ }^{277}$ Carta de J. Sachs, Diretor Executivo do Comitê Auxiliar do JOINT de São Paulo, para o Comitê Auxiliar do JOINT do Rio de Janeiro. São Paulo, 12 de maio de 1949. Fundo 187/AHJB.
} 
paulistana a fim de se informar sobre as decisões do governo federal. A resposta enviada por Tadeusz Lurie, do Rio de Janeiro em 16 de maio de 1949, procurava explicar que os judeus constituíam uma exceção à aplicação da lei:

"Embora sejam assim redigidos os textos legais a prática em muitos casos é diversa. Tratando-se de judeus, os cônsules no exterior frequentemente não deferem os pedidos de vistos sob o pretexto que não podem concedê-los sem autorização do Ministério. Provavelmente estes cônsules não querem assumir a responsabilidade em vista de qualquer circular não publicada (...),278.

Ignorando o verdadeiro conteúdo das circulares secretas, mas sentindo "na pele" as suas conseqüências, os líderes da comunidade judaica procuravam negociar com a diplomacia nacional supondo a persistência de circulares secretas ainda no governo Dutra. Mesmo assim, alguns segmentos dessa mesma comunidade continuam a negar seu próprio passado de resistência ao fascismo e ao autoritarismo brasileiro. Aqueles que afirmam que no Brasil não houve anti-semitismo entre 1937 e 1949 e, por mera conveniência, reafirmam a idéia de um Brasil hospitaleiro, minimizam a força da solidariedade judaica e fortalecem os mitos propagados pelo Estado interessado em ocultar seus atos racistas. Em sua Livre-Docência, Tucci Carneiro afirma que:

“(...) tanto Vargas como Dutra, foram obrigados a sustentar a falsa imagem de presidentes 'liberais'(...) o que explica o fato das circulares contrárias à entrada de judeus no Brasil terem se mantido secretas mesmo no pós-guerra."279

Ao se referir à Circular $n^{\circ} .589$, Leonardo Senkman acrescenta que aquele documento impunha como condição à entrada de agricultores, técnicos e operários, que os mesmos não fossem prejudiciais à composição étnica brasileira. Naquela época, apesar de o Secretário Geral do Ministério de Relações Internacionais brasileiro afirmar que tais restrições não se dirigiam aos judeus, a imprensa carioca denunciava a persistência no novo governo, de antigos "funcionários anti-semitas do regime varguista”. ${ }^{280}$ Thomas Skidmore afirma que uma das críticas feitas pela oposição ao governo Dutra, referia-se à permanência do aparelhamento getulista no novo governo, o

${ }^{278}$ Carta de Tadeusz Lurie, Secretário Geral do Comitê Auxiliar do JOINT do Rio de Janeiro, para J. Sachs, Diretor Executivo do Comitê Auxiliar do JOINT de São Paulo. Rio de Janeiro, 16 de maio de 1949. Fundo 187/AHJB.

${ }^{279}$ Maria Luiza Tucci Carneiro. Cidadão do Mundo: Brasil e a Questão dos Refugiados Judeus (19331948), op.cit., p. 495.

${ }^{280}$ Semanário judaico-carioca Aonde Vamos? de 3 de julho de 1947. Leonardo Senkman, “A Questão Judaica na Argentina e no Brasil: A Contraditória Lógica de Inclusão/Exclusão do Populismo sob Vargas e Perón"Op.cit. 
que havia permitido que "um demasiado número de protegidos de Vargas permanecessem nos cargos $" 281$.

Ao constatar a persistência da política anti-semita herdada do governo Vargas, o Comitê do JOINT do Rio de Janeiro em carta para o JOINT paulistano acrescentou, em 25 de julho de 1949, que independentemente do país europeu em que se encontrasse um consulado brasileiro, o único meio que envolveria ainda uma pequena expectativa de obter um visto, seria um válido contrato de trabalho numa profissão importante para o Brasil. Completou afirmando que “(...) ultimamente não tivemos mais notícias confirmativas da intervenção no Ministério das Relações Exteriores em favor da concessão de vistos brasileiros a pessoas do nosso círculo interessado ${ }^{282}$.

Nesse contexto, nos anos imediatamente após a guerra, muito poucas centenas de sobreviventes do Holocausto eram aceitos entre as 30 mil pessoas deslocadas que o Brasil recebeu segundo acordos com a International Refugee Organization ${ }^{283, " .}$

Conseguir um visto era apenas a primeira de muitas etapas a serem seguidas pelos judeus que buscavam auxilio para sair da Europa. Os Comitês do JOINT sediados em várias capitais européias e americanas funcionavam como uma espécie de base para os interessados em emigrar. A ajuda, no entanto, estava condicionada a algumas exigências que objetivavam atender ao maior número possível de pessoas e, principalmente, aos mais necessitados. Uma das condições estipulava que o candidato ao visto tivesse ao seu dispor um sponsor, um patrocinador que pudesse arcar com os custos de sua viagem e, posteriormente, com sua manutenção no novo país. Os sponsors costumavam ser parentes ou amigos dos refugiados que haviam chegado ao Brasil antes ou durante a Segunda Guerra Mundial. Nos casos em que o refugiado não possuísse ninguém conhecido que pudesse ajudá-lo, o JOINT utilizava seus próprios fundos para patrocinar a viagem.

Exemplar é a história de Andrew Stern, filho de pais húngaros e nascido no Brasil em 1928. Em 1931, Andrew retornou à Hungria ainda criança. Com a eclosão da Segunda Guerra, a Hungria foi invadida pelos exércitos alemães e sua família foi

\footnotetext{
${ }^{281}$ Thomas Skidmore. Brasil: de Getúlio à Castelo. São Paulo, Paz e Terra, 1982. p.95.

${ }^{282}$ Carta de Tadeusz Lurie, Secretário Geral do Comitê Auxiliar do JOINT do Rio de Janeiro, para o Comitê Auxiliar do JOINT de São Paulo. Rio de Janeiro, 25 de julho de 1949. Fundo 187/AHJB. Grifo nosso.

${ }^{283}$ A International Refugee Organization (IRO) foi fundada em 1946 para tratar do crescente problema dos refugiados criados pela Segunda Guerra Mundial. Ela funcionava como uma agência especializada das Nações Unidas. Em 1952, suas operações cessaram e, em seu lugar, foi criada a Comissão de Refugiados das Nações Unidas. Leonardo Senkman. "A Questão Judaica na Argentina e no Brasil: A Contraditória Lógica de Inclusão/Exclusão do Populismo sob Vargas e Perón”, Op.cit, p. 586.
} 
deportada para os campos de concentração. Em 1944, todos haviam sido exterminados, sendo ele o único sobrevivente. Querendo começar “(...) uma nova vida no Brasil”284, Andrew Stern pediu ajuda ao Comitê do JOINT em Budapeste, que se propôs a cobrir os gastos de sua viagem, já que o emigrante não conhecia ninguém que pudesse ajudálo. Em carta para o JOINT paulistano, o Comitê em Budapeste solicitava a presença de algum membro da comunidade judaica no porto de Santos para receber Andrew e encaminha-lo a São Paulo. O jovem seria amparado pelos membros do Comitê paulistano e, conseqüentemente pela CIP, até que se estabelecesse e pudesse recomeçar no novo destino. Por ser natural do Brasil, Andrew Stern não teve nenhum problema para conseguir um visto brasileiro permanente, documento ainda difícil de ser alcançado pelos judeus no final da década de 1940.

O trâmite para a liberação de um visto temporário ou permanente era facilitado quando o interessado se apresentava como católico ou "protegido" por esta fachada. Foi assim que centenas de judeus sobreviventes da guerra e do Holocausto puderam emigrar para o Brasil. Em 1948, Leon Ettinger procurou o Comitê do JOINT paulistano a fim de tentar trazer para o Brasil uma menina, sua parente, que estava vivendo em um convento na Alemanha. A notícia de que a menina estaria sob um teto católico, alegrou aos membros do JOINT paulistano, pois, presumia-se que a garota possuísse documentos alemães, o que facilitaria a concessão de um visto brasileiro:

"A garota abaixo-assinada mora em um convento, então, nós presumimos, ela deve possuir documentos arianos. Nós gostaríamos que você se informasse sobre isso, pessoalmente, e, se ela tiver tais documentos, faça o convento requerer para ela ao Cônsul Brasileiro um visto permanente, ou mesmo um de turista. Se a garota não possuir documentos arianos cordialmente nos informe quais documentos o Cônsul exigiria para conceder um visto de turista." 285

Fragmentos de documentos como esse, demonstram que, em certos casos, seria mais fácil para um alemão católico conseguir um visto para o Brasil do que para um alemão judeu. Marie Thérese, por exemplo, conseguiria um visto permanente somente se possuísse documentos alemães. Caso contrário, se fosse classificada como apátrida,

\footnotetext{
284 “(...) a new life in Brazil”. Carta de Charles Radvany, do Comitê Auxiliar do JOINT de Budapeste, para o Comitê Auxiliar do JOINT de São Paulo. Budapeste, 22 de setembro de 1948. Fundo 187/AHJB.

285 "The above-named girl lives in a convent, so that, we presume, she must have arian papers. We would like you to check upon this, particularly, and, if she had such papers, make the convent apply for her to the Brazilian Consul for a permanent visa, or even a Tourist one. If the girl has no arian papers kindly advise us what documents would the Consul require to grant a Tourist visa." Carta de J. Sachs, Diretor Executivo do Comitê Auxiliar do JOINT de São Paulo, para o Comitê Auxiliar do JOINT de Louvain, Bélgica. São Paulo, 5 de julho de 1948. Fundo 187/AHJB.
} 
suas opções de visto ficavam restritas a uma autorização para visitar o Brasil como turista. Ou seja, assim como durante o Estado Novo, os vistos de turista estavam atrelados à apresentação de uma passagem de ida e volta que, deveria ser portada pelo viajante e apresentada à Polícia Marítima no momento do desembarque: " $O$ patrocinador está pronto para fazer uma afirmação registrada em cartório declarando que ele tomará conta da garota durante sua estadia aqui e também assegurará sua viagem de volta. "286 Tal informação deveria ser transmitida ao Cônsul encarregado de vistar o passaporte de Marie Thérese, caso a mesma não possuísse os documentos alemães necessários. Além de garantir a passagem de volta da viajante, seu sponsor, deveria abrir uma conta em seu nome, para comprovar ao Cônsul brasileiro, que a mesma teria como sobreviver durante os meses em que permanecesse no Brasil. Quanto a tais precauções, J. Sachs, autor da carta em questão, foi enfático: “É desnecessário dizer, isso ocorre apenas se a garota não possuir documentos arianos, porque se ela os tiver, nós não temos dúvida sobre isso, a obtenção de um visto permanente será muito fácil". ${ }^{287}$

Naquela mesma semana, em julho de 1948, outro caso chamaria a atenção do Comitê JOINT paulistano: Bedrich Klein e sua esposa Ilse, sitiados em Praga, na antiga Tchecoslováquia, não conseguiam obter o visto para imigrar ao Brasil. Na tentativa de resolver a questão os JOINTs de Praga, São Paulo e Rio de Janeiro se uniram para resolver o problema do casal. Responsável por estabelecer o contato entre os aspirantes à imigração e seu sponsor, o JOINT em São Paulo encaminhou ao JOINT em Praga uma carta, na qual propunha uma resolução para aquele problema:

\footnotetext{
"Sr. Heiss Fillip, o patrocinador deste caso foi informado pelos emigrantes que o Cônsul Brasileiro em Praga está bem intencionado com relação a Sra. Klein, e nós poderíamos, portanto sugerir, que ela tente obter um visto de turista. No caso disso dar certo, por favor, nos informe quais documentos o Cônsul exigirá (...). Em alguns casos a abertura de uma conta bancária no Banco do Brasil, e uma declaração registrada em cartório de que o patrocinador tomará conta dos emigrantes durante sua estadia no Brasil e viagem de volta, podem ser proveitosas para os emigrantes (...). Caso seja necessário, nós recomendamos que a família seja enviada para Paris, onde eles podem tentar obter seus vistos." 288
}

\footnotetext{
286 "The sponsor is ready to make a notarial statement declaring that he would take care of the girl during her stay here and also assure her trip back" Idem.

287 "Needless to say, this goes only if the girl has no arian papers, because if she had, we have no doubt about it, her obtaining the permanent visa would be very easy". Idem.

288 "Mr, Heiss Fillip, the sponsor of this case was informed by the emigrants that the Brazilian Consul in Prague is very friendly disposed toward Mrs. Klein, and we would, therefore suggest, that she tries to obtain a Tourist visa instead. In case it works out, please inform us, what documents the Consul would require (...). In some cases an opening of bank account at the Bank of Brazil, and a notary statement that
} 
Desde 1938, a obtenção de vistos de turista ou capitalista exigia um depósito no Banco do Brasil, cujos registros merecem ainda a atenção de pesquisadores que terão aqui uma espécie de termômetro deste fluxo que rendeu dividendos aos cofres brasileiros. Segundo Tucci Carneiro, essa tática foi amplamente utilizada pelos judeus que tentavam "negociar" um visto para o Brasil durante o Estado Novo varguista. A Circular Secreta $\mathrm{n}^{\circ} 1249$, expedida pelo Itamaraty em setembro de 1938 impunha, como forma de regular a entrada de semitas em território nacional, que os mesmos fossem turistas ou representantes comerciais, ou que provassem não necessitar de nenhuma ajuda econômica por parte do Estado, transferindo uma determinada quantia para o Brasil. Observamos, pois, que, dez anos depois dessa Circular ser expedida e três anos após o fim do Estado Novo, algumas de suas exigências continuavam a ser cumpridas pela diplomacia brasileira.

Peregrinar por vários consulados e embaixadas diferentes em busca do deferimento de um pedido de visto para o Brasil, foi uma das estratégias utilizadas por aqueles que desejavam imigrar. Em muitos casos, o visto que havia sido indeferido por um cônsul, poderia ser concedido por outro, mais tolerante. Szaja Wajsberg e sua família pretendiam imigrar para o Brasil em janeiro de 1949, partindo de Roma. Naturais da Polônia, a família havia chegado à Itália há cerca de um mês, na esperança de conseguir um visto com o cônsul brasileiro daquele país. Conforme a concessão do documento não acontecia, o JOINT paulistano, em contato com o sponsor da família, procurava outros meios para viabilizar sua emigração. Em carta para o JOINT de Roma, J. Sachs, do JOINT paulistano, informou que o cônsul brasileiro em Paris aceitava conceder vistos, desde que, pautados em contratos de trabalho firmados no Brasil. Deste modo, acreditava que o cônsul brasileiro em missão na Itália, também pudesse emitir o documento nessas mesmas condições:

"Como nós entendemos, o Cônsul Brasileiro em Paris concede vistos tendo como base contratos de trabalho daqui. Você poderia gentilmente consultar se o Cônsul brasileiro na Itália estaria disposto a conceder vistos nas mesmas condições. Enquanto isso, nós iremos, deste modo, tentar conseguir um contrato de trabalho." 289

the sponsor will take care of the emigrants during their stay in Brazil and trip back, might be helpful to the emigrants (...). Should be necessary, we would advise your sending that family to Paris, where they may also try to obtain their visa." Carta de J. Sachs, Diretor Executivo do Comitê Auxiliar do JOINT de São Paulo, para o Comitê Auxiliar do JOINT de Praga, Tchecoslováquia. São Paulo, 6 de julho de 1948. Fundo 187/AHJB.

289 "As we understand, the Brazilian Cônsul in Paris grants visas on grounds of labor-contracts sent from here. Would you kindly check if the Brazilian Consul in Italy would be willing to give visas on the same 
Em geral, os contratos de trabalho exigidos para a concessão de vistos, eram conseguidos junto à própria comunidade judaico-paulista, envolvida nesta rede de solidariedade. Desse modo, o JOINT de Roma foi aconselhado a enviar a família até Paris, como forma de garantir a concessão dos vistos. Caso a obtenção dos vistos não acontecesse, o último recurso seria tentar a autorização de imigração para qualquer outro país da América do Sul, contanto que o Brasil fosse utilizado como "local de trânsito". Assim, quando o navio atracasse no Porto de Santos, o Comitê JOINT de São Paulo poderia tentar, de alguma forma, que a família desembarcasse no Brasil. Os chamados "vistos de trânsito" foram muito comuns entre os refugiados judeus e utilizados como última alternativa possível para ingressar no Brasil.

Apesar de todas as tentativas, os sponsors da família não conseguiram os vistos necessários: “(...) Nós gostaríamos de informá-lo que temos discutido este assunto com os patrocinadores os quais disseram que nenhum passo com qualquer agência daqui foi tomado quanto a prover os migrantes com vistos brasileiros ${ }^{, 290}$. Assim, em fevereiro de 1949, os próprios sponsors, pediram à família, através do JOINT de São Paulo, que desistisse de imigrar para o Brasil, oferecendo ajuda para que Wajsberg, sua mulher e filho fossem para Israel.

Não obstante a peregrinação entre os consulados brasileiros na Europa a fim de se conseguir um visto, alguns países europeus não permitiam, ao menos, que os refugiados entrassem em seus territórios, ainda que temporariamente. Esses países temiam que tais pessoas permanecessem em suas fronteiras. Consequentemente, aqueles que buscavam pela solidariedade de cônsules mais complacentes, muitas vezes, acabavam frustrados por não conseguirem nem alcançar a sede consulado. Este era o caso da Itália que, nesse momento, restringia ao máximo as permissões de trânsito, proibindo que certas categorias de imigrantes permanecessem por muito tempo em seu território, especialmente tratando-se daqueles do Leste europeu: "Como você sabe, o governo italiano não concederá nenhuma permissão oficial para quaisquer pessoas em

conditions. In the meantime, we would in that case, try to get a labour-contract." Carta de J. Sachs, Diretor Executivo do Comitê Auxiliar do JOINT de São Paulo, para o Comitê Auxiliar do JOINT de Roma, Itália. São Paulo, 24 de janeiro de 1949. Fundo 187/AHJB.

290 “(...) we would like to inform you that we have talked over this matter with the sponsors who said that no steps with any agency here have been taken with regard to providing the migrants with Brazilian visas”. Carta de J. Sachs, Diretor Executivo do Comitê Auxiliar do JOINT de São Paulo, para o Comitê Auxiliar do JOINT de Roma, Itália. São Paulo, 10 de fevereiro de 1949. Fundo 187/AHJB. 
trânsito vindas do Leste europeu, ficarem aqui." ${ }^{291}$ Após a Segunda Guerra, a Itália passou a ser tratada pelas instituições judaicas de ajuda como um DP country, compondo ao lado da Alemanha e da Áustria a tríade dos países com maior número de campos de deslocados na Europa.

Em carta de julho de 1948, J. Sachs informou ao JOINT de Roma que, talvez, tivesse uma solução para o problema dos refugiados do Leste Europeu: a solidariedade de um cônsul sul-americano em missão no Brasil que aceitou escrever cartas aos cônsules brasileiros do Leste europeu garantindo que, caso fossem concedidos vistos, provavelmente de trânsito, a refugiados judeus, após a chegada desses emigrantes ao Brasil os mesmos receberiam um visto para outro país sul-americano, o que constituiria uma garantia de que o refugiado não permaneceria em território nacional. ${ }^{292}$

"Em vista das presentes dificuldades envolvendo a emissão de vistos para o exterior para os nossos clientes na Europa, nós gostaríamos de propor, como uma sugestão, que você investigue a possibilidade de países como Romênia, Polônia, Tchecoslováquia, Hungria, Iugoslávia, Bulgária e Grécia emitirem uma permissão de saída com base em uma carta escrita por um cônsul de um país Sul-americano aqui, em São Paulo, prometendo que, após a chegada do emigrante ao Brasil, ele irá conceder-lhe um visto permanente para o respectivo país". ${ }^{293}$

É sabido que, as Circulares Secretas encaminhadas aos diplomatas e embaixadores brasileiros tinham por objetivo a proibição da emissão de vistos aos judeus. Raros foram os funcionários dos consulados brasileiros na Europa que agiram no sentido de burlar essas regras e favorecer a emissão de vistos às vítimas da Guerra e do Holocausto. Tucci Carneiro atenta para esta questão procurando em seus estudos identificar os diplomatas brasileiros que, contrariando as determinações prescritas nas circulares secretas anti-semitas, concederam vistos para que centenas de judeus pudessem recomeçar no Brasil. ${ }^{294}$ Dentre os raros casos, podemos citar o embaixador

\footnotetext{
291 "As you know, the Italian government here will not issue any permission officially to any transients coming in from Eastern Europe, to stay here". Carta de Elka Eliaskevic, do AJDC Emigrants Bureau, para o Comitê Auxiliar do JOINT de São Paulo. Roma, 7 de março de 1949. Fundo 187/AHJB.

${ }^{292}$ Infelizmente, desconhecemos o nome desse cônsul sul-americano.

293 "In view of the present difficulties involving the issuance of overseas visas to our clients in Europe, we would like to propose, as a suggestion that, you investigate the possibility if the countries such Rumania, Poland, Czechoslovakia, Hungary, Jugoslavia, Bulgaria, Greece, would issue an exit permit in the strength of a letter written by a consul of South America country here, in São Paulo, promising that, upon emigrant's arrival in Brazil, he will issue him a permanent visa for the respective country." Carta de J. Sachs, Diretor Executivo do Comitê Auxiliar do JOINT de São Paulo, para o Comitê Auxiliar do JOINT de Roma, Itália. São Paulo, 5 de julho de 1948. Fundo 187/AHJB.

${ }^{294}$ Maria Luiza Tucci Carneiro. O Anti-semitismo na Era Vargas, Op.cit.
} 
Luiz Martins de Souza Dantas, cuja ação solidária é tema central da obra de Fábio Koifman $^{295}$.

Nessa mesma época, os diplomatas brasileiros em missão na Itália recusavam-se a vistar quaisquer passaportes de refugiados. Dentre as exceções temos um cônsul em Florença, que aceitava conceder vistos de turista para aqueles que comprovassem ter residência fixa e legal naquela cidade há, pelo ou menos, dois anos. Diante desta possibilidade, os escritórios da JDC situados na Itália tentavam, ao menos, garantir vistos aos judeus que aguardavam um destino nos campos para deslocados de guerra ${ }^{296}$.

Entre o final do ano de 1948 e o inicio de 1949, chegou ao conhecimento dos Comitês Auxiliares do JOINT do Rio de Janeiro e de São Paulo que, a partir daquele momento, o governo francês exigiria que os interessados em transitar pelo território da França portassem uma confirmação, por escrito, de que lhes seria concedido um visto para imigrar. Tal documento deveria ser assinado pelo cônsul que outorgaria o visto. Um novo problema delineava-se, então, para as associações judaicas: o cônsul brasileiro em missão na França recusava-se a conceder a requerida autorização, a menos que recebesse ordens diretas do Ministro da Imigração. Por outro lado, sem conseguir "entrar" na França, os emigrantes eram impedidos de buscar seus vistos e providenciar os detalhes de seu transporte para a América. Cabia aos Comitês JOINT brasileiros movimentarem-se no sentido de conseguir que o Ministro telegrafasse aos seus funcionários na França, autorizando os procedimentos necessários.

Não obstante, o Cônsul brasileiro em Paris passou a requerer como pré-requisito para a concessão de vistos de turista ao Brasil, a prova de que o pleiteante teria residência fixa na França há mais de três anos. Consequientemente, em relação aos vistos permanentes, o JOINT acreditava que sequer valeria a pena pedi-los, pois, segundo Charles Jordan, as leis brasileiras de imigração que autorizavam a concessão de vistos àqueles considerados "interessantes a composição étnica da população brasileira", eram interpretadas como uma forma de excluir as pessoas de fé judaica"297.

Diante desses fatos, a resolução do JOINT passada aos Comitês paulistano e carioca expunha que seria inútil tentar conseguir vistos para o Brasil através do consulado de Paris:

\footnotetext{
${ }^{295}$ Fábio Koifman, Op. cit.

${ }^{296}$ Carta de J. Sachs, Diretor Executivo do Comitê Auxiliar do JOINT de São Paulo, para o Comitê Auxiliar do JOINT de Roma, Itália. São Paulo, 10 de fevereiro de 1949. Fundo 187/AHJB.

297 Special Inter-office Memo $n^{\circ} 41$, de Charles H. Jordan. American JOINT Distribution Committee, Paris/França. Paris, 13 de novembro de 1948. Fundo 187/AHJB.
} 
"Até as condições para vistos de turista Brasileiros, ou a interpretação para a concessão de vistos permanentes, mudarem, não há razão em enviar pessoas em direção à Paris. Portanto, a menos que uma pessoa já possua uma carta válida de um Cônsul prometendo emitir-lhe um visto - e isso é excepcional - não envie qualquer pessoa para o Brasil através de Paris." 298

Apesar de todas as proibições, em relatório de 1951, o JOINT comemorava a retirada de cerca de 215.000 refugiados de campos de deslocados na Europa, inclusive dos campos italianos ${ }^{299}$. Além disso, a instituição se responsabilizava por inserir novamente na sociedade européia, e principalmente francesa, aqueles que eram considerados "não cidadãos", desempregados e sem possibilidades para sustentar suas famílias. Eram protegidas também as crianças órfãs e as pessoas mais idosas. Devido à constância de problemas financeiros, tentativas eram feitas pelo JOINT no sentido de localizar parentes dos sobreviventes para transferir-lhes os encargos do seu sustento.

Interessante notar que, se por um lado conseguir um visto para o Brasil era tarefa difícil, em alguns registros dos escritórios do JOINT, tal dificuldade parece estar superada. Por outro lado, acompanhando as tramitações e as negociações através da correspondência entre o JOINT e os interessados, contatamos que nem sempre os resultados eram os esperados. Por exemplo, Efraim Grandiski e sua mulher Ester, grávida de seis meses, tinham a possibilidade de emigrar para o Brasil, chamados por um amigo da família que atuaria como seu sponsor, cobrindo todos os gastos de sua viagem. No entanto, em maio de 1948, a única autorização conseguida pelo casal em Genova, na Itália, era um visto para o Paraguai. J. Sachs enviou uma carta para o JOINT sueco, responsável pelo caso, informando que o sponsor do casal possuía excelentes conexões no Porto de Santos e, assim, poderia desembarcá-los mesmo que possuíssem apenas um visto de trânsito:

“Como você deve saber, a emigrante Ester está grávida de seis meses, e nós gentilmente pedimos a você para apressar este caso e, especialmente fazer todo o possível para conseguir-lhes um visto de turista Brasileiro ou pelo ou menos um visto de trânsito. O patrocinador possui vários bons contatos no Porto de Santos, que podem ser muito úteis no caso de você conseguir obter esses vistos, os quais, nós pensamos, são um pouco mais fáceis de obter neste momento. Em uma próxima carta, nós enviaremos a você

\footnotetext{
298 "Until the requirements for the Brazilian tourist visas, or the interpretation for issuance of permanent visas, change, there is no point in sending people forward to Paris. Therefore, unless a person already holds a valid letter from the Consul promising to issue a visa - and this is exceptional - do not send any people for Brazil forward to Paris". Idem.

299 Relatório enviado por Edward M.M. Warburg, Presidente do American Jewish JOINT Distribution Committee, em Nova York, para o Comitê Auxiliar do JOINT de São Paulo. Nova York, 25 de maio de 1951. Fundo 187/AHJB.
} 
uma declaração preenchida pelo patrocinador, manifestando sua intenção de ajudar estas pessoas durante sua estadia aqui (eles devem conseguir um visto de turista) e também sustentar seu transporte de volta". 300

Note que, na maior parte dos documentos expostos até aqui, nem se considerava conseguir um visto permanente, como se uma autorização para visitar o Brasil por 90 dias fosse, reconhecidamente, a única opção à disposição do refugiado. Outro aspecto interessante no trecho exposto é a noção, transmitida por J. Sachs, de que seria fácil conseguir um visto para o Brasil naquele momento. Tratava-se, logicamente, de um visto de turista que, por sua vez, dependia da apresentação, junto à representação diplomática brasileira no exterior, de uma declaração de total responsabilidade por parte do mantenedor da família e, de passagens de ida e volta como forma de demonstrar que o prazo estabelecido pelo visto seria respeitado. Não obstante, para que os imigrantes pudessem ficar definitivamente no Brasil, o visto de turista ou de trânsito deveria ser transformado em permanente, trâmite que exigia amizades e contatos com as autoridades da emigração.

No caso específico do casal Grandiski, não era possível esperar por muito tempo a concessão de um visto, pois, esperava-se que o bebê de Ester nascesse em solo brasileiro e, deste modo, garantisse a estadia de seus pais no país. No entanto, até o final de julho daquele mesmo ano, a situação não havia sido resolvida e o bebê acabou nascendo mesmo na Suécia. Além disso, o visto que se considerava fácil de conseguir no consulado brasileiro em Estocolmo, não havia sido emitido. $\mathrm{O}$ cônsul brasileiro daquela localidade exigia, como prerrogativa para a emissão de um visto de turista, a apresentação das passagens de retorno. Assim, o mantenedor da família no Brasil deveria depositar nas contas do JOINT uma quantia adicional, da qual ele não dispunha naquele momento.

Como segunda opção, J. Sachs pediu ao JOINT sueco que enviasse a família para Paris, “(...) obtendo primeiro, é claro, um visto de trânsito francês.” ${ }^{01}$, onde

\footnotetext{
300 "As you may know, the emigrant Ester is in the family way gone six months, and we kindly ask you to speed up this case, and especially to do everything possible to get them a Brazilian Tourist visa or at least a Brazilian Transit one. The sponsor has great many connections in the Port of Santos, which may be very useful in case you succeed in obtaining those visas, which, we should think, are a trifle easier to obtain at the moment. By the next mail we shall send you a notary statement made out by the sponsor, declaring his willingness to support these people during their stay here (should they get a Tourist visa) and also maintain their transportation back". Carta de J. Sachs, Diretor Executivo do Comitê Auxiliar do JOINT de São Paulo, para o Comitê Auxiliar do JOINT de Estocolmo, Suécia. São Paulo, 21 de maio de 1948. Fundo 187/AHJB.
} 
acreditava que os mesmos conseguiriam obter vistos para o Brasil com maior facilidade. Além dos vistos, a estadia em Paris permitiria que o casal comprasse passagens de segunda ou terceira classe, num navio com destino ao Brasil. O mesmo não seria possível na Suécia, pois, naquele ano, apenas um navio partiria daquele país rumo à América do Sul e, tratava-se de um cruzeiro de luxo, cujas passagens tinham um preço muito elevado $^{302}$. Importante assinalar que o sponsor era totalmente responsável pelo custeio do imigrante mesmo que este ainda estivesse na Europa. No caso exposto, os gastos com o sustento e moradia da família na Europa e com as passagens utilizadas para viajar de um país para outro, corriam todos por conta de seu sponsor no Brasil.

Em maio de 1949, a família Grandicki, diante de tantas dificuldades para imigrar para o Brasil, resolveu mudar o destino de sua viagem e informou ao seu sponsor sua decisão de ir para Israel. Em carta J. Sachs lamentou a decisão da família:

"Nós gostaríamos, entretanto, de nossa parte que, você mais uma vez informe aos Grandicki que eles, em sua decisão de ir para Israel, onde no presente momento é muito difícil para os recém-chegados, estão perdendo uma grande chance, caso eles não tentem com mais firmeza no Consulado Brasileiro. Até onde nós sabemos, assim que os Grandicki chegarem ao Brasil, ele (Sr. Grandicki) irá imediatamente entrar no já bem estruturado negócio de seu patrocinador, oportunidade que muitos gostariam de ter." ${ }^{303}$

A existência de um sponsor que arcasse com os gastos do imigrante, principalmente àqueles relacionados à legalização, tornou-se algo imprescindível no inicio da década de 1950. O imigrante que não possuísse um patrocinador estava, praticamente, impossibilitado de viajar. A correspondência entre o Comitê Auxiliar do JOINT e os escritórios do JOINT em outros países demonstram que aqueles anos foram de dificuldades financeiras para todos, principalmente para o núcleo paulistano. Em 1951, Salo Wissmann escreveu para Moses A. Leavitt, Vice-Presidente do JOINT, a fim de garantir que uma pequena soma de dinheiro fosse enviada para os programas de assistência aos imigrantes judeus dirigidos pelas organizações judaico-paulistanas

301 “(...) obtaining first, of course, french transit visa”. Carta de J. Sachs, Diretor Executivo do Comitê Auxiliar do JOINT de São Paulo, para o Comitê Auxiliar do JOINT de Estocolmo, Suécia. São Paulo, 29 de julho de 1948. Fundo 187/AHJB.

${ }^{302}$ Carta de J. Sachs, Diretor Executivo do Comitê Auxiliar do JOINT de São Paulo, para o Comitê Auxiliar do JOINT de Estocolmo, Suécia. São Paulo, 18 de agosto de 1948. Fundo 187/AHJB.

303 "We would like, however, from our side that, you once more advise the GRANDICKI's that they in their decision to go to Israel, where at the moment is very difficult for the newcomers, are missing a big chance, if they not try harder at the Brazilian Consulate. As far as we know, upon GRANDICKI's arrival to Brazil he would immediately enter in the already well set-up business of the sponsor's, opportunity which many would like to have". Carta de J. Sachs, Diretor Executivo do Comitê Auxiliar do JOINT de São Paulo, para o Comitê Auxiliar do JOINT de Estocolmo, Suécia. São Paulo, 11 de maio de 1949. Fundo 187/AHJB. 
especializadas em recepcionar os recém-chegados. Como resposta, Wissmann recebeu elogios e uma recusa:

"Nós sabemos que você concorda conosco que o dinheiro necessário para a assistência aos recém-chegados, e para outros aspectos do trabalho local de assistência social, deve ser levantado por cada comunidade (...). Em primeiro lugar é conveniente para cada comunidade judaica ser auto-suficiente. São Paulo tem demonstrado plenamente sua capacidade para estabelecer, operar e financiar os serviços de organização necessários à comunidade judaica. Mais do que isso, tem sido um líder e pioneiro na América do Sul nesse campo de operações." ${ }^{304}$

Segundo o JOINT, sua prioridade deveria ser a assistência aos judeus que estavam em áreas nas quais não havia uma comunidade judaica estruturada. Considerando a comunidade judaico-paulistana como a mais bem organizada dentre todas aquelas situadas na América do Sul, Moses Leavitt acreditava que o Comitê JOINT não precisava mais de ajuda financeira, tendo tornado-se auto-suficiente desde o final da década de 1940. É certo que, diante do poderio econômico de alguns membros da comunidade judaico-paulistana, como a família Klabin, a auto-suficiência não só era possível, como também confortável para o Comitê paulistano. O problema eram os gastos não programados, pois, apesar de praticamente auto-suficiente, o Comitê não contava com uma reserva para imprevistos.

No inicio do ano de 1952, A Sra. Kapluch e sua filha Ida chegaram ao porto do Rio de Janeiro portando apenas vistos de trânsito pelo Brasil, com destino final para o Paraguai. A intenção das duas era a de permanecer no Brasil e o JOINT de Munique, que agilizou seus processos, estava ciente desse desejo. Diante dessa atitude, aparentemente inofensiva, o Comitê de São Paulo se desespera, pois, processos de legalização eram ainda muito caros nessa época e, se o JOINT não pretendia mais ajudar financeiramente a associação paulistana, por que então enviava imigrantes sem vistos de permanência e sem recursos para o Brasil?

“Como nós escrevemos para você repetidas vezes é legalmente impossível legalizar vistos de trânsito com exceção de casos extraordinários. Todavia, estes transmigrantes

\footnotetext{
304 "We know that you agree with us that monies needed for assistance to newcomers, and for other aspects of local welfare work, should be raised by each community (...) In the first place, it is to the advantage of each Jewish community to be self-sufficient. Sao Paulo has fully demonstrated its capacity to establish, operate and finance the necessary Jewish community organizations services. More than that, it has been a leader and a pioneer in South America in that field of operations." Carta de Moses A. Leavitt, Vice-Presidente Executivo do American Jewish JOINT Distribution Committee, em Nova York, para Salo Wissmann. Presidente do Comitê Auxiliar do JOINT em São Paulo. Nova York, 6 de dezembro de 1951. Fundo 187/AHJB.
} 
têm sucesso algumas vezes em legalizar sua situação por custos muito altos e procedimentos impossíveis para as organizações" 305

Além dos altos custos da legalização, existia ainda o problema da manutenção do imigrante enquanto o mesmo estivesse no Brasil. Segundo a legislação brasileira, até que lhe fosse concedida a permissão para permanecer definitivamente no Brasil, o imigrante não poderia trabalhar e prover o seu próprio sustento. Caberia às associações judaico-paulistanas despender elevadas quantias para legalização e sustento do recémchegado e de sua família. Diante das reclamações de Hans Hamburger, o JOINT parisiense alegou que "Ficou claro por um bom tempo que somente aqueles protegidos com parentes no Brasil, os quais afiançavam seus sustentos etc. para irem ao Brasil, seriam ajudados por nós em seus transportes. ${ }^{~} 306$. Ou seja, num momento posterior à guerra, em que a integridade física do membro da comunidade judaica, teoricamente, não seria mais violada, o papel do JOINT passava a ser o de facilitador da parte burocrática e patrocinador das passagens para emigração.

No caso da Sra. Kapluch, era sabido que a mesma não possuía qualquer parente na América do Sul. No entanto, a senhora havia afirmado ao JOINT de Paris que portava a quantia necessária para manter-se no Brasil até que estivesse com a documentação preparada e em condições de trabalhar. Tal promessa mostrou-se infundada logo que a imigrante e sua filha chegaram ao Brasil. Sem condições de se auto-sustentarem e, sem conhecer ninguém que lhes pudesse ajudar, caberia à CIP os cuidados necessários às duas mulheres.

No início da década de 1950, os Comitês do JOINT da América do Sul enviaram aos escritórios centrais suas idéias para solucionar a problemática do sustento dos imigrantes: os Comitês sul-americanos deveriam conseguir uma declaração dos sponsors, assinada, na qual houvesse a promessa de comprometimento total com os imigrantes desde o seu desembarque no novo país. Em último caso, seriam aceitas declarações rubricadas pelo próprio imigrante, obrigatoriamente feitas em três vias e enviadas pelo Comitê que o auxiliou inicialmente, ao Comitê do país sul-americano

\footnotetext{
305 "As we wrote you again and again it is legally not possible to legalize transit visas with the exception of extraordinary cases. In despite of this transmigrants sometimes succeeded in legalizing their situation at very high costs and procedures impossible for organizations." Carta de Hans Hamburger, Diretor Executivo do Comitê Auxiliar do JOINT em São Paulo, para o American Jewish JOINT Distribution Committee de Nova York e Paris. São Paulo, 15 de abril de 1952. Fundo 187/AHJB.

306 "It has been clear for quite a while that only those proteges with relatives in Brazil who guaranteed the maintenance, etc. for their relatives going to Brazil, would be helped by us with their transportation." Carta do American Jewish JOINT Distribution Committee de Paris, para Hans Hamburger, Diretor Executivo do Comitê Auxiliar do JOINT em São Paulo. Paris, 6 de maio de 1952. Fundo 187/AHJB.
} 
para o qual ele se dirigiria. Tais medidas deveriam ser tomadas, pois, muitos emigrantes, na ânsia de poder recomeçar, declaravam possuir condições de se sustentar e legalizar a sua situação no novo país para o qual iriam. No entanto, ao chegarem a seus destinos, anunciavam que suas declarações eram falsas e requeriam auxilio por parte das associações judaicas instaladas nesses países:

"Nós estamos repetindo esse aviso já que continuamos recebendo denúncias dos Comitês de que, embora os migrantes assinem declarações antes da partida, uma vez na América do Sul, eles geralmente anunciam que foram forçados a assinar tais declarações antes de partirem e insistem em assistência, legalização, etc." ${ }^{307}$

O excessivo número de vitimas deixado pela Segunda Guerra Mundial resultou na constância da insuficiência de recursos por parte de algumas associações beneficentes de auxilio, como a CIP. A formação do Estado de Israel e a emergência do ideal sionista viriam agravar ainda mais essa situação. Em relação ao restante da comunidade brasileira, gói, esta documentação demonstra que o processo de democratização do Brasil diante da aceitação do outro, respeitando suas diferenças, foi sempre muito lento. A postura humanitária assumida pelo Brasil diante das Nações Unidas (ONU) era frágil, desprovida de sentimentos de solidariedade. Somente após a década de 19502 é que a comunidade judaica radicada n Brasil encontrou condições para florescer e expor a sua identidade.

\footnotetext{
307 "We are repeting this warning since we continually receive complaints from the Committees that although migrants sign declarations before departure, once in South America, they generally proclaim that the signing of such declarations were forced upon them prior to departure and they insist on assistance, legalization, etc." Comunicado de Emanuel Rosen, Diretor Associado do American Jewish JOINT Distribution Committee, de Buenos Aires, para Beatrice Vuncan, Diretora do American Jewish JOINT Distribution Committee de Viena, Áustria. Buenos Aires, 25 de janeiro de 1952. Fundo 187/AHJB.
} 


\section{IV - A COMUNIDADE JUDAICA EOS SÚDITOS DO EIXO}

\section{1 - A CIP e os Súditos do Eixo}

Entre 1942 e 1945, os membros da coletividade judaica brasileira foram atormentados pela possibilidade de serem detidos pela Polícia Política sob a acusação de serem súditos do Eixo. Confundidos com seus algozes por serem alemães, austríacos ou poloneses, dentre outras nacionalidades colaboracionistas dos nazistas, os judeus viveram dias tensos e traumáticos aqui no Brasil. Desde a ascensão de Hitler ao poder na Alemanha, em 1933, o governo brasileiro demonstrou, em muitos aspectos, nutrir simpatias pelo regime nazi-fascista, postura que levou o governo brasileiro a se declarar neutro diante da eclosão da Segunda Guerra Mundial. No entanto, a pressão norteamericana, principalmente após 1939, agia no sentido de afastar o governo brasileiro das ideologias nazistas e convencê-lo a receber centenas de refugiados judeus espalhados pela Europa. Por outro lado, diante das pretensões desenvolvimentistas de Getúlio Vargas para o Brasil, o Presidente sentia-se propenso a aceitar ideologicamente a potência que lhe oferecesse maiores possibilidades de ganho no campo econômico. A apelidada "dualidade varguista" se estendeu até 1942, momento em que se concretizaram as propostas norte-americanas para a construção da Companhia Siderúrgica de Volta Redonda. Nesse ano, o Brasil, através de decreto presidencial, rompeu suas relações diplomáticas com os países componentes do Eixo - Alemanha, Itália e Japão - delegando à Polícia Política o poder de vigiar, prender e neutralizar possíveis núcleos de "súditos eixistas", 308

Desde o inicio de seu governo, Getúlio Vargas adotou uma posição pragmática em relação à política externa, negociando com aqueles que atendessem aos seus interesses e simpatias ideológicas. O período compreendido entre 1934 e 1939 caracterizou-se pela crescente participação da Alemanha no comércio exterior brasileiro. Segundo Boris Fausto, a Alemanha tornara-se então, a principal compradora do algodão brasileiro e, em 1938, fecharia um importante acordo com o Brasil para o fornecimento de artilharia ${ }^{309}$. Por outro lado, a eclosão da Segunda Guerra Mundial, no ano seguinte, levaria os Estados Unidos a preencher o vazio comercial deixado pela

\footnotetext{
${ }^{308}$ Renata Mazzeo Barbosa. Judeus em Tempos de Guerra. A Comunidade Judaica e os Súditos do Eixo. Pesquisa de Iniciação Cientifica. São Paulo, apoio FAPESP, 2002-2204.

${ }^{309}$ Boris Fausto. História do Brasil. São Paulo: Edusp, 2002, p.380.
} 
Inglaterra na América Latina. Mais especificamente em relação ao Brasil, em 1940, os Estados Unidos estabeleceu a chamada "Política da Boa Vizinhança", visando a constituição de um sistema continental pan-americano que anulasse o projetado sistema pan-germânico. A resposta brasileira a tais iniciativas consistiu em aproximar-se, cada vez mais, de seu vizinho do Norte, procurando conseguir maiores vantagens. A entrada dos Estados Unidos na Segunda Guerra, em 1941, forçou Getúlio Vargas a uma resolução: aderir à linguagem do pan-americanismo. No final de 1941, os Estados Unidos instalou tropas norte-americanas no nordeste brasileiro e, no ano seguinte, assinou com o Brasil um acordo político-militar de caráter secreto ${ }^{310}$. O Brasil estava definitivamente na guerra contra o nazi-fascismo.

Para Roberto Gambini, o Brasil seria o país que apresentava melhores condições para os projetos de expansão da influência alemã na América Latina. As colônias de imigrantes alemães em território brasileiro, contavam com cerca de $85 \%$ de adeptos do nazismo. Assim, o fato de o Brasil ter se alinhado ideologicamente aos Aliados gerou grande tensão para os alemães emigrados dos países do Eixo ${ }^{311}$.

O predomínio da ideologia nazista entre os nacionais da Alemanha explica o recrudescimento da vigilância policial brasileira sobre os imigrantes "súditos do Eixo": japoneses, italianos e alemães. Partindo-se do pressuposto de que todo alemão poderia desenvolver práticas nazistas, a repressão policial sobre a comunidade alemã urbana deveria acontecer independentemente de sua identificação com o ideário do III Reich. Isso acarretou na prisão de centenas de imigrantes alemães de forma arbitrária, justificada apenas pela situação de guerra e legitimada pelo conceito político de "perigo

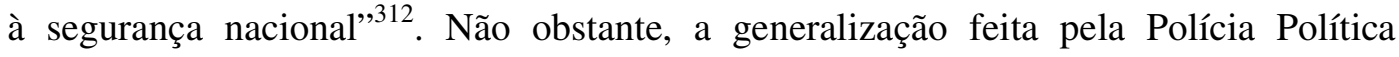
atingiu muitos dos judeus expulsos ou emigrados da Alemanha, acusados então por práticas nazistas. A partir de 1942, cabia à seção de segurança nacional evitar atitudes agressivas e ofensivas dos "súditos do Eixo", vigiar as autoridades consulares desses países, fechar as entidades estrangeiras eixistas e impedir qualquer manifestação de tais grupos $^{313}$.

Apenas alguns meses depois do rompimento das relações diplomáticas com os países do Eixo, a comunidade judaico-paulistana já sentia os primeiros efeitos daquela

\footnotetext{
${ }^{310}$ Boris Fausto. Op. $c$ it. p 383.

${ }^{311}$ Roberto Gambini, O Duplo Jogo de Getúlio Vargas: Influência Americana e Alemã no Estado Novo. São Paulo, Símbolo, 1977.

312 Priscila Ferreira Perazzo. O Perigo Alemão e os Mecanismos de Repressão Policial no Estado Novo, São Paulo, Divisão de Arquivo do Estado, Coleção Teses e Monografias, 1999.

${ }^{313}$ Ibid. p. 48.
} 
decisão. Segundo o rabino Fritz Pinkuss, de origem alemã e também refugiado no Brasil,

“(...) nós éramos, a partir de então, qualificados como súditos de nacionalidades inimigas, sofrendo restrições por isso. Ao mesmo tempo, muitos cidadãos de origem italiana ou alemã, no sul, eram considerados nacionais" ${ }^{314}$.

A partir de 1942, centenas de refugiados judeus foram, pois, detidos sob a acusação de colaborar com o regime de Hitler. Nicolau Manoel Kaufmann, refugiado judeu e austríaco que, apesar de ser brasileiro naturalizado, foi acusado em setembro de 1942, pelo DEOPS-SP, por ser um "exaltado elemento pró-nazismo", alardeando a todos que "ninguém poderia sobrepujar o poderio da Alemanha"315. Para convencer o aparato policial de sua inocência foi necessário que Kaufmann relembrasse, em pedido feito à Polícia, todo o drama vivenciado na Europa nazista:

"O suplicante teve oito pessoas mortas e três suicídios em sua família, por causa do regime hitlerista. Com efeito, acompanhando a presente petição vai junta uma declaração do Snr. Geza Reichmann (...) o qual foi prisioneiro da Gestapo, juntamente com a mãe e a esposa do suplicante, e este, pelo espaço de três meses em Viena, sendo que a mãe e a esposa do suplicante vieram posteriormente a falecer, em conseqüência da perseguição sofrida. (...). Ainda mais: o suplicante que era dono de uma casa bancária, em Viena, foi despojado da administração daquela casa bancária e, para poder ser posto em liberdade e poupar a sua vida, foi obrigado a entregar toda a siua fortuna $\mathrm{O}$ Reich, o qual dela se apossou(...).,316

Geza Reichmann, também refugiado judeu e austríaco, havia estado preso com Kaufman por três meses no Quartel da Gestapo em Viena. Seu depoimento foi tomado pela Polícia a fim de verificar a veracidade dos fatos relatados por Kaufmann. Reichmann, por sua vez, fora preso dias depois em sua própria casa, por agentes do Serviço Secreto da Polícia Política. Colocado à disposição do Departamento de Ordem Política e Social de São Paulo, Reichmann permaneceu detido por dois meses, sob a acusação de colaborar com os países do Eixo $^{317}$. Caso semelhante aconteceu com Rudolf Joseph que, em outubro de 1942, apesar de declarar-se seguidor da religião

\footnotetext{
${ }^{314}$ Fritz Pinkuss. Op. cit. P. 60.

${ }^{315}$ Relatório da Sub-Chefia de Ordem Política e Social enviado ao Sr. Delegado Especializado de Ordem Política e Social. São Paulo, 08 de junho de 1943. Pront. $n^{o} .51379$, de Nicolau Manoel Kaufman. DEOPS/SP. APESP.

316 Abaixo -assinado de Nicolau Manuel Kaufmann para o Major Hildebrando Vierira de Mello, Superintendente da Segurança Política e Social. Departamento de Ordem Política e Social. São Paulo, 8 de junho de 1943. Pront. $n^{o} .51379$, de Nicolau Manoel Kaufman. DEOPS/SP. APESP.

317 Informe de Arthur Reis Machado, encarregado da turma "B", para o Dr. Manoel Ribeiro da Cruz, Delegado Especializado de Ordem Política e Social da Capital. São Paulo, 24 de agosto de 1942. Pront. $n^{o} .11268$ de Geza Reichman. DEOPS/SP. APESP.
} 
israelita, foi preso. Acusado de "fazer propaganda nazista em plena via pública (...) $)^{318}$, Joseph foi, dentre tantos outros, vitima do autoritarismo do governo brasileiro. Outros membros da comunidade judaica, apesar de nunca terem sido presos, foram vigiados, investigados e protagonizaram muitos dos devaneios da Polícia Política paulistana. Em agosto de 1944, a interceptação de uma correspondência pelo Serviço de Censura Postal do DEOPS de São Paulo, provocou uma detalhada investigação acerca de um dos membros mais ilustres da CIP: o Dr. Alfred Hirschberg, editor do jornal Crônica Israelita. Hirschberg havia enviado um relatório bilíngüe em inglês e alemão para o Dr. Fritz Bamberger, em Chicago e, para Ernest Lowenthal, em Londres, editores dos periódicos Coronet e Esquire, respectivamente. Traduzida pela Polícia, a correspondência tratava dos fuzilamentos ocorridos na Alemanha em junho de 1934, após a revolta de Roehm. Ainda na Alemanha, Alfred Hirschberg fora, naquela data, procurado pela esposa de um jovem médico judeu que havia sido levado por membros da Gestapo para um interrogatório, sendo depois encontrado morto, com tiros na cabeça. Para poder receber o dinheiro da apólice do seguro de vida de seu marido, a senhora em questão, precisava comprovar que o mesmo não estava envolvido em nenhum tipo de revolta e, que havia sido morto por motivos de vingança pessoal. Como pertencia à diretoria de uma das mais importantes organizações judaica-alemã, Hirschberg se dirigiu até o quartel-general da Gestapo a fim de conseguir uma declaração sobre os motivos que haviam levado o jovem médico à morte. Enquanto o oficial alemão procurava o nome do médico judeu em sua lista de fuzilados daqueles dias, Hirschberg percebeu que a tal lista possuía cerca de 32 páginas e, que em cada página, havia o nome de 31 pessoas. Ou seja, segundo a listagem, mais de 900 pessoas haviam sido fuziladas sob a assinatura de Adolf Hitler.

Diante da leitura da tradução do relatório escrito por Hirschberg, o Delegado Especializado de Ordem Política e Social concluiu que o mesmo, aparentemente, seria anti-nazista. No entanto, conviria ao Departamento de Ordem Política investigar mais sobre o remetente daquela correspondência, a fim de apurar seu "nome completo $e$ nacionalidade, afazeres comuns, locais que freqüenta, tendências políticas" ${ }^{319}$. Após quase dois meses de investigação, o Serviço Secreto da Polícia Política de São Paulo

\footnotetext{
${ }^{318}$ Auto de Qualificação de Rudolf Joseph. São Paulo, 19 de outubro de 1942. Pront. $n^{\circ}$. 45244, de Rudolf Joseph. DEOPS/SP. APESP.

${ }^{319}$ Parecer do Delegado Especializado de Ordem Política e Social. Departamento de Ordem Política e Social de São Paulo. São Paulo, 31 de julho de 1944. Dossiê 41-B-50 de Alfred Hirschberg. DEOPS/SP. APESP.
} 
possuía um amplo panorama acerca do cotidiano, das atividades e dos relacionamentos de Alfred Hirschberg. No entanto, nos documentos anexados ao dossiê inexiste qualquer tipo de declaração feita pelo próprio investigado, o que nos leva a crer que todo o relatório tenha sido elaborado com base em vigilância policial:

“(...) Dr. Alfred Hirschberg é seu nome completo e é de nacionalidade alemã (...). Ocupa o cargo de Superintendente da Congregação Israelita Paulista e é colaborador do jornal bi-manal editado por essa agremiação. Diariamente, dirigi-se à sede da referida congregação no período da tarde e nas demais horas, dedica-se ao jornalismo em sua própria residência, levando assim sua vida particular um tanto retraída. Suas tendências políticas são fortemente anti-nazistas (...).",320

O agente do Serviço Secreto descobrira também que Hirschberg chegara ao Brasil em 1940, vindo da Inglaterra, onde se encontrava refugiado da Alemanha. Aí, fazia parte da Associação dos Cidadãos Alemães de Fé Israelita, motivo segundo o qual, fora preso por várias vezes, sendo, até mesmo, internado em um campo de concentração e despojado de toda a sua fortuna pelos nazistas. Através de um inquérito aplicado a algumas pessoas próximas ao investigado e do conhecimento de sua história de luta pessoal contra o nazismo, a Polícia é levada, então, a concluir que o mesmo alinhava-se ideologicamente ao Brasil.

Além daqueles detidos e investigados por suspeita de atividades nazistas, havia ainda o problema dos mais idosos, constantemente atormentados pela Polícia Política por conversar em língua alemã, em público. Para esses, restava o apoio da CIP, que muitas vezes foi a responsável por retirar das prisões esses estrangeiros que não conseguiam se comunicar em português.

As restrições aos "súditos do Eixo" foram legalizadas a partir da declaração de guerra contra a Alemanha, a Itália e o Japão, no início de 1942. Visando a geopolítica do controle, os Departamentos Estaduais de Ordem Política e Social instituíram o uso de salvo-condutos para quaisquer viagens, principalmente para as cidades portuárias, como Santos e Rio de Janeiro, por exemplo. ${ }^{321}$ O direito de "ir e vir" dos suspeitos por

\footnotetext{
${ }^{320}$ Relatório do "S-4" para o Chefe do Serviço Secreto. Superintendência de Ordem Política e Social. São Paulo, 26 de setembro de 1944. Dossiê 41-B-50 de Alfred Hirschberg. DEOPS/SP. APESP.

321 Quando um estrangeiro (identificado como "súdito do Eixo") precisava viajar para outra cidade ou Estado, por motivos de saúde, negócios ou lazer, tornava-se necessário solicitar a devida autorização junto à Secção de Salvo-Condutos, setor do DEOPS. Nesse pedido deveria constar, além de seus dados pessoais (nome do requerente, filiação, data de nascimento, nacionalidade, naturalidade, local de residência, número da carteira de identificação, número do registro geral), o local para onde se pretendia ir, o motivo e a duração da viagem, o meio de transporte a ser utilizado e o local onde ficaria hospedado. Durante a viagem, o indivíduo deveria apresentar essa autorização quando abordado por um policial e, na
} 
atividades eixistas foi cerceado também pela imposição da Circular de $1^{\circ}$ de setembro de 1943, que regulamentava a transferência de residência de "súditos do Eixo", segundo os interesses da Segurança Nacional ${ }^{322}$. A promulgação do Decreto-lei no. 4166, autorizava o confisco dos bens dos súditos alemães, italianos e japoneses como forma de reparar os prejuízos sofridos pelo governo brasileiro diante do estado de guerra ${ }^{323}$. Em sua biografia, o Rabino Pinkuss relembra esse período com tristeza:

“(..) o Decreto-lei 4166, que atingiu a nós, judeus alemães - nós, que já havíamos perdido a nacionalidade alemã, alguns por decreto individual e muitos por decreto coletivo -, identificando-nos como de uma nacionalidade inimiga por termos tido um dia uma cidadania que já nos fora retirada! Lembro-me de que, um dia, no desejo de receber um documento que comprovava a expatriação coletiva dos judeus, dirigi-me ao Consulado Alemão (...), Naturalmente, foi-me recusado. Durante a conversa, um funcionário teve a audácia de propor inscrever-me como alemão no próprio consulado $(\ldots)^{, 324}$

Além da tentativa de isentar-se de culpa pela expatriação de milhares de judeus dos países dominados pelo nazismo, o Consulado alemão propôs ainda devolver a cidadania àquele que havia sido expulso pelo Estado nazista. Ou seja, os alemães que se sentissem injustiçados pelas novas determinações do governo federal brasileiro poderiam recorrer ao consulado de seu país como forma de garantir a solução dos seus problemas. Mas, sem possuir sequer um estado nacional, muito menos, um Consulado, a quem os refugiados judeus, em sua grande maioria apátridas, deveriam recorrer?

Sempre atuante e preocupada com o bem-estar coletivo, entre 1942 e 1945, a coletividade judaica de todo o Brasil, principalmente em São Paulo e Rio de Janeiro agiu no sentido de buscar a diferenciação entre os judeus e os verdadeiros "súditos do Eixo". Conseqüentemente, tentariam anular as restrições impostas aos judeus alemães e italianos por ocasião do estado de guerra. Diante dessa realidade, a comunidade judaicopaulistana, através da Congregação Israelita Paulista, começou a articular estratégias que pudessem ser utilizadas para tal. A primeira ação dessa associação frente às

\footnotetext{
falta desse, seria encaminhado à Delegacia de Polícia mais próxima. Ao chegar à localidade escolhida, o visitante deveria ir à Delegacia local informar por quanto tempo ficaria na cidade e os motivos pelos quais estava ali.

${ }^{322}$ A mudança de residência, quando para outro Estado, exigia tanto a autorização do Delegado local, como do outro Delegado responsável pela região para a qual o interessado desejava transferir-se. Quando autorizadas, as transferências eram publicadas no Diário Oficial, o que possibilitava informar a todos os órgãos públicos sobre o paradeiro do estrangeiro, garantindo o auxílio para sua vigilância.

${ }^{323}$ Decreto-lei $n^{o} .4166$ de 11/03/1942. Dispõe sobre as indenizações devidas por atos de agressão contra bens do Estado brasileiro e contra a vida e bens de brasileiros ou de estrangeiros residentes no Brasil.

${ }^{324} \mathrm{O}$ autor não especifica a data exata em que tal situação ocorreu. Fritz Pinkuss. Op. cit. p. 61.
} 
resoluções do Decreto $n^{\circ} .4166$ foi a de enviar uma extensa carta ao Ministro da Justiça e Negócios do Interior, a fim de esclarecer a situação dos refugiados judeus no Brasil:

"Todos os israelitas do Brasil acompanham o desenrolar dos acontecimentos que nos conduzem à guerra com o mesmo sentimento patriótico que despertaram em todo o nosso povo. Em face da brutal agressão de que fomos vítimas, viram com entusiasmo a ação enérgica e decisiva do governo, e aplaudiram incondicionalmente as medidas postas em prática relativamente aos súditos do Eixo aqui residentes, medidas que visaram assegurar a defesa de nossas instituições, prevenindo uma possível ação subversiva e constituíram justo revide ao injustificável atentado que conta o Brasil se cometeu.

Para que fosse feita, entretanto, a estrita justiça que notoriamente constituía o propósito do governo, seria necessário que se examinasse, ao se aplicarem aos súditos do Eixo as medidas restritivas de que cogitam os diferentes decretos promulgados até essa data, a situação dos refugiados israelitas da Alemanha e da Itália, que, aqui tendo chegados banidos pelos governos de seus países de origem, acham-se sob a ameaça de ser considerados, em virtude de seu lugar de origem, também como súditos do Eixo, e de ser atingidos, consequentemente, pelas mesmas medidas restritivas que a eles foram impostos.

(...) Ao passo que os alemães e italianos não refugiados constituem, em terra brasileira, como que um prolongamento de sua pátria de origem, à qual sempre estiveram e continuam ligados, da qual sempre receberam apoio e proteção diplomática, os israelitas se viram, desde a instauração do nazismo, na Alemanha e, na Itália, desde a aliança entre Hitler e Mussolini, banidos de seus lares, privados de seus direitos, irremissivelmente desligados da comunidade a que haviam pertencido, e obrigados a procurar outros povos que, generosa e compreensivelmente os soubessem acolher $(\ldots)^{, 325}$

O autor relata ainda toda a sorte de dificuldades sofridas pelos judeus nos países europeus ocupados por Hitler, as prisões, as deportações, a formação dos guetos, a fome, o frio, as epidemias de doenças e as internações em campos de concentração. Além disso, cita a legislação nazi-fascista responsável por confiscar todos os bens dos judeus alemães e italianos. Diante desse quadro de extrema crueldade, tornara-se impossível continuar vivendo naqueles países, o que fez com que milhares de judeus procurassem refúgio em outros lugares.

"Em face do exposto, é evidente que os israelitas refugiados, primeiras vítimas do nazifascismo, são os seus mais intransigentes adversários, e os mais decididos partidários dos aliados na luta que hoje se trava ente a civilização e a barbárie" ${ }^{\text {"326. }}$.

\footnotetext{
${ }^{325} \mathrm{Na}$ data de produção desse documento, março de 1942, o Ministro de Estado, Justiça e Negócios Interiores em exercício no Brasil era Vasco Tristão Leitão da Cunha. Website do Ministério da Justiça. Carta de Ludwig Lorch, Presidente do Conselho da Congregação Israelita Paulista para o Exmo. Senhor Doutor Ministro da Justiça e Negócios do Interior. São Paulo, 23 de março de 1942. Fundo Lorch/LEER - USP.

${ }^{326}$ Idem.
} 
Acreditando ser correta e imprescindível a ação do governo brasileiro em relação à guerra que acontecia na Europa, o autor da carta em questão, Ludwig Lorch, procurou mostrar ao Ministro da Justiça a diferença que existia entre os judeus refugiados e os verdadeiros "súditos do Eixo". Mas como os judeus poderiam fazer com que o governo brasileiro os aceitasse simplesmente como judeus, sem que possuíssem nenhuma nacionalidade? Durante o regime hitlerista, decretou-se que todos os judeus nãoalemães “(...) deviam ser privados de sua cidadania antes da deportação ou, ao mais tardar, no dia em que fossem deportados". ${ }^{327}$ Ainda segundo Hannah Arendt, no caso dos judeus-alemães, esse decreto não era necessário porque existia uma lei no III Reich segundo a qual todo o judeu que fosse deportado ou deixasse o território alemão, perderia automaticamente sua cidadania ${ }^{328}$. Nesse sentido, a ascensão de Hitler ao poder na Alemanha e a conseqüente fuga dos judeus dos países ocupados pelos nacionalsocialistas produziram milhares de novos apátridas. Por outro lado, aqueles que haviam imigrado ao Brasil em períodos anteriores a 1933, apesar de conservarem sua nacionalidade a mantinham apenas no papel; em seu íntimo, estavam cientes de ter perdido sua pátria-mãe, referência de identidade nacional. Não obstante, a chegada ao Brasil thes havia garantido apenas a permissão para permanecer no país, pois, não lhes foram dadas as condições para tornarem-se cidadãos brasileiros. Pairava no ar a constante preocupação de que o anti-semitismo poderia aflorar também nos países sulamericanos que não ocultavam suas simpatias pela Alemanha.

Nesse contexto e diante do Decreto-lei $\mathrm{n}^{\circ}$. 4166, a CIP tentou ainda obter a naturalização para todos os judeus refugiados, sem sucesso. A situação judaica no Brasil, nesse momento, pode ser melhor interpretada através das reflexões de Hannah Arendt em Origens do Totalitarismo:

“(...) a condição de apátrida, que é o mais recente fenômeno de massas da história contemporânea (...) um novo grupo humano, em contínuo crescimento, constituído de pessoas sem Estado, grupo sintomático do mundo após a Segunda Guerra Mundial” ${ }^{\text {"29 }}$.

Nenhum país estava preparado para a questão dos apátridas e dos refugiados de guerra. Um caminho viável para a resolução de seu problema seria conceder-lhes a naturalização em outro país. Porém, como nenhuma nação, com raras exceções, queria outorga-lhes uma pátria, seria mais fácil restituir-lhes sua nacionalidade de origem. $\mathrm{Na}$

\footnotetext{
${ }^{327}$ Hannah Arendt. Op.cit. p.313.

${ }^{328}$ Idem.

${ }^{329}$ Hannah Arendt. Op.cit. p. 310.
} 
verdade, estavam sendo ignorados pelas autoridades de muitos países que, indiferentes ao drama vivenciado pelos judeus, preferiam ignorá-los.

No entanto, em sua exposição, Ludwig Lorch sugere, de forma sutil, que a naturalização era o melhor caminho a ser seguido pelo governo brasileiro com o objetivo de evitar possíveis confusões decorrentes do estado de guerra. Identificado com o seu povo e, enquanto líder de sua comunidade, Lorch argumentou com base nas qualidades do povo judeu, ressaltando a aplicação de recursos nas lavouras e indústrias brasileiras, além de explicitar suas ações em direção à assimilação:

\begin{abstract}
"Os moços refugiados falam em suas casas apenas o português. As crianças freqüentam e freqüentaram as escolas brasileiras, onde aprendem no convívio com os seus colegas a amar e a respeitar sua nova pátria. Muitos dos refugiados casando-se com brasileiros, ou aqui tendo filhos, estreitaram ainda mais os laços que os ligavam à terra que tão hospitaleiramente os acolhera (...). Aqueles que se puderam valer das exceções previstas em lei, já requereram a sua naturalização; outros o fa-lo-ão certamente, uma vez que isso lhes seja facultado (...),330
\end{abstract}

A fim de colaborar para a viabilização da distinção solicitada, Ludwig Lorch expõe ao Ministro brasileiro da Justiça e Negócios do Interior, alternativas que ajudariam a identificar possíveis espiões nazistas travestidos como vítimas do nazifascismo. Considerando que em todo país existiam associações judaicas presididas por brasileiros natos, essas poderiam fornecer ao governo informações e garantias sobre a situação particular de cada refugiado, além de atestar sua lealdade ao Brasil. A coletividade judaica estaria, então, como forma de gratidão ao país que os acolhera, colaborando com o governo federal "na luta sem trégua que se está travando e que somente a vitória final da causa aliada poderá fazer cessar" ${ }^{\text {331 }}$. O Brasil poderia ainda, imitar seus parceiros Aliados, como Estados Unidos e Inglaterra, cujos territórios possuíam um número muito maior de refugiados judeus, o que não os impedira de inventar formas legais de distinção entre o inimigo nazi-fascista e suas vítimas. $\mathrm{Na}$ Inglaterra, por exemplo, segundo Lorch, os judeus possuíam uma ressalva em suas carteiras de identidade que os classificava como "um estrangeiro amigo". 332

Até que ponto a declaração de guerra contra os países do Eixo representaria mais que uma simples questão de aliança econômica, cabe ainda à historiografia atual

\footnotetext{
${ }^{330}$ Carta de Ludwig Lorch, Presidente do Conselho da Congregação Israelita Paulista para o Exmo. Senhor Doutor Ministro da Justiça e Negócios do Interior. São Paulo, 23 de março de 1942. Fundo Lorch/LEER - USP.

${ }^{331}$ Idem.

${ }^{332}$ Idem.
} 
desvendar. É sabido que, ideologicamente, o Estado Novo talvez não se afastasse com tanto empenho daqueles que dizia combater. Quiçá por isso, os pedidos e sugestões para distinção feitos pela comunidade judaica, logo no início da definição brasileira de alinhamento na Segunda Guerra Mundial contra o Eixo, não tenham sido levados em consideração e tantos outros judeus tenham continuado a ser detidos pelas DOPS estaduais, confundidos com seus carrascos nazistas.

Após perceber que seu apelo fora ignorado, a Diretoria a Congregação Israelita Paulista decidiu então, em novembro de 1942, enviar José Midlin, Vice-presidente da CIP, ao Rio de Janeiro a fim de conversar com o Ministro da Justiça, Dr. Marcondes Filho. Após o encontro, o interlocutor relatou, em uma carta, quais teriam sido as partes mais importantes da conversa e as respostas do Sr. Ministro àquilo que lhe havia sido pedido. O objetivo da visita era claro: entregar ao Ministro um memorial relatando todas as vicissitudes sofridas pelos judeus na Europa ocupada por Hitler, os motivos que os fizeram emigrar, sua condição de apátridas, a gratidão e o carinho que sentiam pelo Brasil e, "pedir ao governo, em nome da CIP, que examinasse a possibilidade de se estabelecer uma distinção entre os refugiados israelitas da Alemanha e da Itália, e os súbditos do Eixo"333. Segundo o visitante, a ausência dessa distinção poderia favorecer a ação dos "quinta-colunistas" constituindo, ainda, uma extensão da perseguição nazista levada a cabo na Europa.. As respostas dadas pelo Ministro a tais apelos foram transcritas no relatório:

“O problema Dr. M. não é tão simples como pode parecer. É possível que a Inglaterra e os EE.UU. o tenham conseguido resolver, mas não sei se as circunstâncias são as mesmas. O Sr. sabe que o governo tem procurado facilitar a vida dos estrangeiros (...). O Sr. que é de São Paulo sabe que há para o governo outros problemas semelhantes. Sabe que existe aqui um contingente muito mais numeroso que o dos refugiados, aqui residente há muito mais tempo, com largos serviços prestados ao país, e que também pretende ver reconhecida sua identificação com o nosso meio. É o contingente italiano. Muitos deles estão há quarenta ou cincoenta anos, e, no entanto, as vezes um detalhe qualquer revela que ainda não são brasileiros (...) Eu não quero dizer que a situação dos refugiados seja a mesma desses italianos aqui residentes. Muitas circunstâncias de suas vidas são únicas. Mas devo dizer-lhe que a parte do que sofreram na Alemanha não commove. Não commove porque esse sofrimento já foi equilibrado, compensado, pelo fato de nós os termos recebido aqui. Poderíamos não recebe-los, deixando que vagassem nesses navios phantasmas, como judeus errantes. Poderíamos dizer que o problema não nos dizia respeito, e que não tínhamos qualquer obrigação de acolhe-los (...). É o que eu Dr. M., fazendo questão de recebe-lo, quiz lhe dizer, para lhe mostrar o

333 Informações Reservadas para conhecimento da Diretoria e Comissão de Relações Públicas da Congregação Israelita Paulista. s/d. Fundo Lorch/LEER - USP. 
quanto é difícil, complexo, delicado, no momento, um acto resolutório do governo, no sentido que o $\mathrm{Sr}$, pleiteia." 334

Nessa explanação o Ministro Marcondes Filho ${ }^{335}$ deixou claro ao seu interlocutor que, naquele momento, para o governo federal brasileiro seria mais importante cuidar da questão dos imigrantes italianos, “com largos serviços prestados ao país”, do que de problemas referentes aos refugiados judeus. Sob a alegação de que aquele contingente seria mais numeroso do que esse último, o Ministro tentou convencer o Vice-presidente da CIP de que os problemas italianos mereceriam maior urgência do que os judaicos. Além disso, o sofrimento infringido aos judeus na Europa, segundo o Ministro, já deveria ter sido superado por aqueles que haviam conseguido imigrar para o Brasil. Acolhendo alguns milhares de refugiados sem que houvesse qualquer obrigatoriedade para isso, o Brasil acreditava fazer mais do que o suficiente pelos judeus, vítimas da Segunda Grande Guerra. Nesse sentido, um novo pedido ao governo federal proveniente da comunidade judaico-paulistana não teria razões para existir, já que a submissão de toda a comunidade judaico-brasileira às mesmas leis aplicadas aos suspeitos de atividades nazi-fascistas não era algo que enternecesse o governo. Por isso, Marcondes Filho diz não estar comovido com o problema daqueles refugiados, já que, graças à bondade do governo brasileiro, os mesmos não estavam por aí, vagando como "judeus errantes" 336 .

Nessa linha de pensamento, Marcondes Filho esqueceu-se apenas de dimensionar a diferença existente entre os problemas vivenciados pelos imigrantes italianos e aqueles que os judeus vinham enfrentando. No caso, a grande maioria católica dos imigrantes italianos havia emigrado para o Brasil em condições completamente diferentes: fugiam da fome e da falta de trabalho na Itália, e não da morte em campos de concentração planejados pelos nazi-fascistas. Entre a minoria identificada com a religião judaica, estavam aqueles que, após 1938, haviam sido expulsos de suas casas na Itália em decorrências das leis raciais impostas por Benito

\footnotetext{
${ }^{334}$ Informações Reservadas para conhecimento da Diretoria e Comissão de Relações Públicas da Congregação Israelita Paulista. s/d. Fundo Lorch/LEER - USP.

335 Alexandre Marcondes Machado Filho foi Ministro de Estado, Justiça e Negócios Interiores no Brasil entre 17/07/1942 à 03/03/1943.

${ }^{336} \mathrm{O}$ judeu errante é um personagem mítico, que faz parte dos mais remotos ciclos de tradições orais cristãs. Tratar-se-ia de um contemporâneo de Jesus Cristo, o judeu chamado Ahsverus habitante de Jerusalém; ali, trabalhava, num cortume, ou oficina de sapateiro, que ficava numa das ruas por onde os condenados à morte por crucificação passavam carregando suas cruzes. Na Sexta-Feira da Paixão, Jesus Cristo, passando por aquele mesmo caminho carregando sua cruz, foi importunado com ironias, ou agredido verbal ou fisicamente, pelo coureiro Ahsverus. Jesus, então, o teria amaldiçoado, condenando-o a vagar pelo mundo, sem nunca morrer, até a sua volta, no fim dos tempos.
} 
Mussolini $^{337}$. Centenas desses refugiados buscavam asilo no Brasil considerando que, em São Paulo havia uma grande comunidade de imigrantes italianos. Certamente, em sua explanação, Marcondes Filho não se referia a estes judeus italianos, e nem estava preocupado em julgar se os refugiados judeus, italianos ou alemães estavam sendo injustamente suspeitos por práticas eixistas.

Segundo Giralda Seyferth, no artigo "A assimilação dos imigrantes como questão nacional”, o governo brasileiro durante a Segunda Guerra Mundial, manifestava certa predileção pelos italianos, em detrimento dos alemães e japoneses, já que, acreditavam que os primeiros fossem mais assimiláveis e menos organizados ideologicamente. Em meio a uma forte campanha nacionalista, definida por Seyferth de "cruzada anti-nazista”, o governo varguista acreditava que “(...) os alemães eram os mais alienígenas, os italianos estavam mais próximos dos brasileiros, e os poloneses ocupavam um espaço intermediário (...)"338.

No entanto, sobre a cabeça de todos os possíveis "eixistas" pairavam as determinações do Decreto-lei $n^{\circ} .4166$ que impunha que todos os bens pertencentes aos súditos alemães, italianos e japoneses poderiam ser confiscados pelo governo federal como forma de reparar ao Brasil, os prejuízos causados pelas agressões provenientes dos países do Eixo:

"Art. $1^{\circ}$ Os bens e direitos dos súditos alemães, japoneses e italianos, pessoas físicas ou jurídicas, respondem pelo prejuízo que, para os bens e direitos do Estado Brasileiro, e para vida, os bens e os direitos das pessoas físicas ou jurídicas brasileiras, domiciliadas ou residentes no Brasil, resultaram, ou resultarem, de atos da agressão praticados pela Alemanha, pelo Japão ou pela Itália.

Art. $2^{\circ}$ Será transferida para o Banco do Brasil, ou, onde este não tiver agência, para as repartições encarregadas de arrecadação de impostos devidos à União, uma parte de todos os depósitos bancários, ou obrigações de natureza patrimonial superiores a dois contos de réis, de que sejam titulares súditos alemães, japoneses e italianos, pessoas físicas ou jurídicas.”. 339

Sob o risco de perderem tudo o que haviam conseguido conquistar no país de acolhimento, muitos imigrantes, dentre eles os refugiados judeus, passaram a pressionar o governo brasileiro em busca de uma solução para o problema da generalização dos “inimigos de Estado". Sob este prisma é que deve ser interpretada a visita de Mindlin ao

\footnotetext{
${ }^{337}$ Sobre este tema ver Anna Rosa Bigazzi, Op.cit.

338 Giralda Seyferth. “A assimilação dos imigrantes como questão nacional”. Rio de Janeiro, Scielo.br, abril de 1997. p. 07.

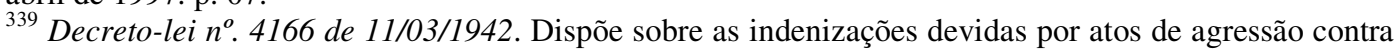
bens do Estado brasileiro e contra a vida e bens de brasileiros ou de estrangeiros residentes no Brasil.
} 
Ministro Marcondes Filho. No entanto, com exceção de alguns casos isolados, a legislação brasileira só começou a ser modificada após o final da Segunda Guerra Mundial. Consideramos interessante avaliar a convergência entre as idéias e opiniões expressas acima pelo Dr. Marcondes Filho e a "rápida" mudança efetivada nas leis de modo a atender as reivindicações dos imigrantes italianos: os bens dos súditos italianos foram liberados dos efeitos do Decreto $\mathrm{n}^{\circ} .4166$ em abril de 1946, enquanto que as contas bancárias do restante dos "súditos do Eixo" somente seriam liberadas em 1948, e os efeitos do referido decreto só cessariam definitivamente no final de $1950^{340}$.

Menos de dois meses após a promulgação do Decreto $\mathrm{n}^{\circ}$. 4166, o governo federal lançou a Portaria $\mathrm{n}^{\circ} .8408$, regularizando a forma da declaração de patrimônio que deveria ser realizada por todos os "súditos do Eixo" até o dia 31 de maio de 1942. O $2^{\circ}$ artigo dessa portaria definia quais pessoas deveriam ser considerados súditos alemães, italianos e japoneses, excetuando aqueles que haviam perdido ou conseguido novas nacionalidades, mediante a apresentação do devido registro a ser aceito pelo governo brasileiro. Aos judeus que haviam sido expulsos da Alemanha, após 1933, delineava-se uma possibilidade de distinção em relação aos naturais dos países dominados pelo nazismo. O registro exigido pelo governo federal e expedido pela Secção Consular da Embaixada da Alemanha, nada mais era do que uma certificação no passaporte do judeu indicando que aquele cidadão "por decreto de 26 de novembro de 1941, perdeu a nacionalidade alemã ${ }^{, 341}$. No entanto, tal registro deixara de ser concedido pelas embaixadas alemãs no Brasil desde a declaração de rompimento das relações diplomáticas entre estes dois países. Diante dessa situação, as associações cariocas UNIAO e a ARI - responsáveis, sempre, por pleitear junto ao governo federal uma legislação mais justa para os refugiados judeus - aconselhavam aos seus amigos e associados que, através de um advogado de confiança pessoal, produzissem uma “justificação em que se provará que V.S. não é súdito do Eixo":

"Em virtude do Decreto-lei n ${ }^{\circ} .4166$, e da Portaria Ministerial nº.8408, essa Associação julga de seu dever aconselhá-lho ao que se segue. Em face dos textos das leis acima indicadas, supomos que será do interesse do nosso caro associado que, por intermédio de um advogado de sua confiança pessoal, produza em juízo uma justificação em que se provará que V.S. não é súdito alemão, italiano ou japonês. Esse documento judicial que, no momento, não terá efeito de decidir definitivamente a situação de V.S., poderá no

\footnotetext{
${ }^{340}$ Respectivamente: Decreto-lei $n^{o} .9123$ de 3/04/1946. Dispõe sobre a liberação de bens de súditos italianos; Lei $n^{o} .291$ de 22/06/1948. Dispõe sobre a abertura de contas bancárias de súditos do Eixo; Lei $n^{o}$. 1224 de 4/11/1950. Dispõe sobre a liberação dos bens dos súditos do Eixo.

${ }^{341}$ Comunicado de Paul Zander, Presidente da "União", Associação Beneficente Israelita, aos sócios. Rio de Janeiro, maio de 1942. Fundo Lorch/LEER - USP.
} 
futuro, talvez próximo, ser-lhe muito necessário, si tanto o interpretarem as autoridades que o irão examinar."342

Tal documento não se mostrou determinante de uma modificação da condição judaica no Brasil após a declaração de guerra ao Eixo. Em setembro de 1942, Ernst Wolff, judeu refugiado da Alemanha, foi detido sob a acusação de manifestar-se a favor do Eixo, razão que determinou o confisco de seus bens $\mathrm{s}$ de acordo com os preceitos estabelecidos pela legislação dos "tempos de guerra". Desconhecemos quais foram os caminhos percorridos por Ernst Wolff para conseguir a restituição de seus direitos. No entanto, sabemos que o Decreto-lei $n^{\circ}$. 24.293, de 31 de dezembro de 1947, liberou os bens pertencentes a Ernst Wolff considerando que:

“(...) os valores pertencentes a Ernst Wolff, natural da Alemanha, se originaram de remessa que fêz, muito antes de flagrada a guerra, para atender a exigências das leis imigratórias brasileiros com intento de vir residir no país,

Considerando que a sua vinda para o Brasil não se efetivou por motivos alheios à sua vontade;

Considerando que participou da guerra nas fôrças aliadas, as quais prestou relevantes serviços, e que desde maio de 1944 é cidadão americano por naturalização,

DECRETA:

Art. $1^{\circ}$ Ficam liberados dos efeitos do Decreto-lei nº .4 .166 , de 11 de março de 1942, os bens pertencentes a Ernst Wolff., ${ }^{343}$

Segundo o texto da lei, a restituição dos bens de Ernst Wolff só foi possível porque este comprovou tê-los trazido para o Brasil antes da deflagração da Segunda Guerra Mundial, no cumprimento de exigências feitas pelo governo brasileiro àqueles que pretendiam imigrar. Além disso, o Sr. Wolff, apesar de oriundo da Alemanha, não integrava o grupo dos refugiados de guerra, não possuía mais a naturalidade alemã e, tampouco, era apátrida: possuía naturalização norte-americana. Considerou-se ainda, sua participação como soldado integrando as fileiras do exército Aliado contra o Eixo. O "caso Wolff" constituía, assim, uma exceção em meio a maioria da comunidade judaico-brasileira. Para esses, restava acompanhar as ações das associações comunitárias e aguardar pela modificação da legislação.

Ainda em 1946, Hans Hamburger relatou à Diretoria do JOINT sobre a situação dos judeu-alemães no Brasil desde 1942: “A lei considera como alemão qualquer pessoa que entrou no Brasil com um passaporte alemão. Deste modo, os judeus

${ }^{342}$ Comunicado de Eduardo Levy, Presidente da Associação Religiosa Israelita do Rio de Janeiro, aos sócios. Rio de Janeiro, 8 maio de 1942. Fundo Lorch/LEER - USP.

${ }_{343}^{34}$ Decreto-lei $n^{\circ}$. 24.290 de 31/12/1947. Libera dos efeitos do decreto-lei 4166, de 11 de março de 1942, os bens pertencentes a Ernst Wolff, natural da Alemanha. 
refugiados da Alemanha em sua grande maioria são também considerados alemães". 344

Segundo Hamburger, o controle efetuado pelo Banco do Brasil sobre os "súditos do Eixo"era extremamente rigoroso e quaisquer venda ou compra de imóveis, empréstimos ou contratação de seguros deveria se previamente aprovada por aquela instituição. Todavia, todos os pedidos de suspensão das determinações da lei $\mathrm{n}^{\circ} .4166$ aos judeus, realizados pela CIP e pelo Comitê Representativo dos Interesses dos Judeus Alemães no Brasil não haviam sido, até então, levados em consideração. Hans Hamburger comenta ainda que, o último desses pedidos feito em setembro de 1945 e, endereçado ao Presidente da República, não havia, ao menos, sido respondido, e foi diretamente repassado à recém-criada Comissão das Reparações de Guerra: "Pode ser que essa demora na decisão sobre este último requerimento seja devido à Conferência de Paz de Paris, onde o Governo Brasileiro pretende reivindicar uma participação nas reparações de guerra “345.

O rompimento de relações diplomáticas do Brasil com os países do Eixo tornara os navios brasileiros alvo de ataques dos submarinos alemães. Nos sete meses seguintes, cerca de 20 navios mercantes brasileiros foram torpedeados na costa do país, causando centenas de perdas humanas. A participação no esforço de guerra aliado e, principalmente, o envio da FEB - Força Expedicionária Brasileira - ao front italiano, em 1944, levaram o governo brasileiro a supor que o país teria um papel importante a desempenhar nas negociações de paz do pós-guerra, na qualidade de "potência associada" e "aliado especial" dos Estados Unidos. As reivindicações de indenização pelas perdas da guerra e de um assento permanente no Conselho de Segurança da ONU transformaram-se, deste modo, em prioridades da diplomacia brasileira, embora as negociações relativas a tais assuntos tenham ficado, desde o início, restritas às grandes potências participantes das conferências aliadas.

Dois anos após o término da Segunda Guerra Mundial, discussões na Câmara dos Deputados Federal visavam decidir de que modo deveria ocorrer a liquidação dos bens confiscados em decorrência do Decreto-lei $n^{\circ} .4166$. A lei havia sido promulgada para restituir ao Brasil possíveis perdas materiais causadas pelos países do Eixo durante

344 "The Law considers as German every person, who entered Brazil with a German passport. Therefore the Jewish refugees from Germany in their great majority are also considered Germans." Carta de Hans Hamburger, do Comitê Representativo do Interesse dos Judeus Alemães no Brasil, para o JOINT. São Paulo, 24 de setembro de 1946. Fundo Lorch/LEER - USP.

345 "It may be that this delay of deciding about this last application is due to the Paris Peace Conference, where the Brazilian Governmente intends to claim a participationin War-reparations". Carta de Hans Hamburger, do Comitê Representativo do Interesse dos Judeus Alemães no Brasil, para o JOINT. São Paulo, 24 de setembro de 1946. Fundo Lorch/LEER - USP. 
a Segunda Guerra, porém, ao final dela, tais danos haviam sido menores do que se mensurava. Qual seria então o mais acertado? Devolver todos os bens confiscados ou mantê-los em posse do governo?

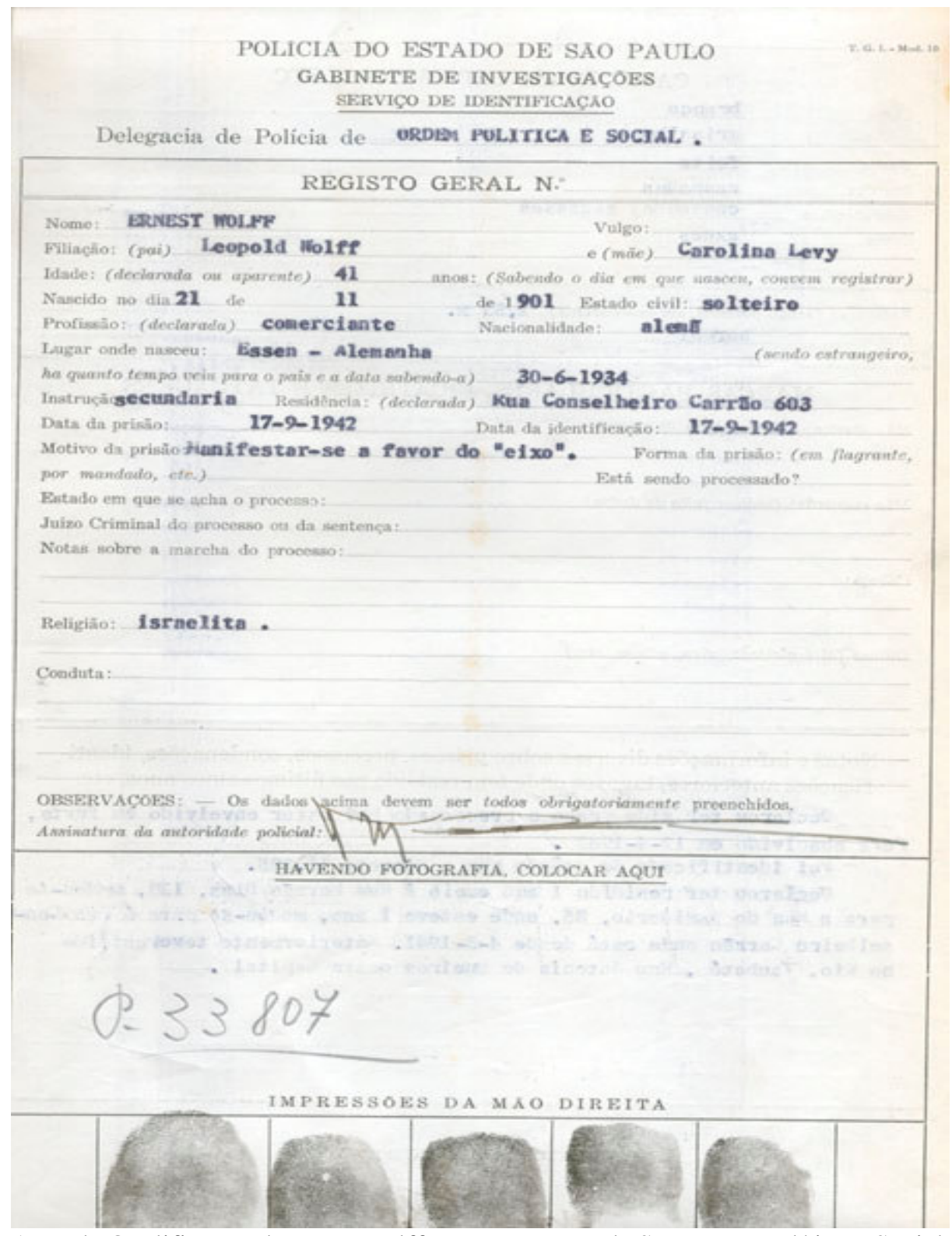

- $\quad$ Auto de Qualificação de Ernst Wolff. Departamento de Segurança Política e Social. São Paulo, 17 de setembro de 1942. Prontuário $n^{o} .33807$ de Ernst Wolff. DEOPS/SP. APESP.

Nas exposições em plenário de 1947, aqueles que defenderam a liberação total dos bens dos "súditos do Eixo" foram vencidos por aqueles que pleiteavam a venda imediata dos bens confiscados e o recolhimento da quantia conseguida ao Banco do Brasil numa conta chamada Fundo de Indenização. Este fundo serviria para indenizar todo e qualquer dano causado a pessoas físicas e jurídicas, resultante "de depreciações 
ou outras manifestações populares ocorridas em território brasileiro a partir de 1942, inclusive, e motivadas pela guerra ou por atos de opressão praticados contra o Brasil

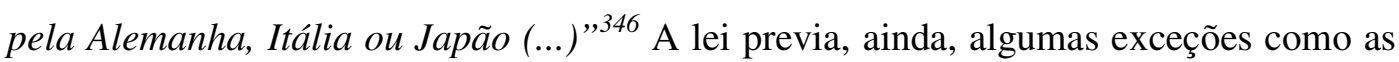
propriedades rurais dos alemães residentes no Brasil e os bens dos súditos japoneses, já que o Japão não havia causado nenhum dano material ao Brasil no decorrer da guerra. Os bens dos súditos italianos também foram desobrigados da lei, pois, o Brasil havia assinado um tratado de paz com a Itália, no pós-guerra:

"Nestas condições, a decretação da venda de bens pertencentes a italianos assume caráter de ato gravemente inamistoso para com um país ao qual estamos ligados por laços de toda a natureza. Desse ato não decorrerá vantagem alguma para o Brasil (...) O fato de ser o Brasil a única das nações vitoriosas a manter em seqüestro os bens dos italianos não pode deixar de ter, entre outras, funestas conseqüências sobre nossas relações comerciais (...)"347

O governo brasileiro voltava-se então, unicamente, aos imigrantes alemães, entre os quais estavam centenas de judeus, apropriando-se de uma vingança que, não exatamente, lhe dizia respeito. Apesar de cientes das implicações causadas à comunidade judaica pelo confisco de seus bens, pois, durante anos a coletividade se pronunciou junto às esferas do poder federal a fim de regularizar sua situação, os legisladores não incluíram os judeus entre nenhuma das exceções previstas em lei.

Ainda em 1942, a Congregação Israelita, não obstante o fracasso em pleitear alterações na legislação prevista durante o estado de guerra encarado pelo Brasil, denunciou aos seus correligionários a situação enfrentada pela comunidade judaicopaulistana e brasileira. A Crônica Israelita em sua edição de 5 de dezembro de 1942 explicitava em sua primeira página a questão dos "súditos do Eixo", que extrapolava os "fenômenos materiais e financeiros". A perturbação se faria sentir muito mais enquanto "situação psicológica e moral":

"O relatório começa quase que matematicamente com o momento em que o nosso continente entrou na guerra e, termina com o momento auspicioso da invasão da Europa. A tensão geral da humanidade pelas peripécias da guerra, a participação cada vez mais intensa do Brasil nos próprios acontecimentos da guerra, encontraram os seus reflexos no meio da nossa Congregação.

Acresce que as medidas tomadas pelo Brasil contra os atentados do nazi-fascismo a vida e propriedade brasileira, atingiram fortemente numerosos sócios da Congregação, naturais da Alemanha e da Itália. Não foram tantos os fenômenos materiais e

\footnotetext{
${ }^{346}$ Cópia da ata da Sessão Plenária da Câmara dos Deputados do Distrito Federal brasileiro. s/d, 1947. Fundo 187/AHJB.

${ }^{347}$ Idem.
} 
financeiros que perturbaram os nossos sócios, mas a sua situação psicológica e moral, isto é, o fato de que foram atingidos primeiro e com mais intensidade, pelo nazifascismo alemão, para depois, além das fronteiras dos países que os haviam perseguido, serem equiparados aos seus perseguidores.

A Congregação que sempre se preocupou com a situação moral, material e jurídica dos refugiados, vítimas do nazismo, aproveitou todas as possibilidades para obter uma solução adequada ao problema ligado à definição 'súditos do Eixo'. Consubstanciaramse esses esforços em telegramas, memoriais, palestras com personalidades competentes e, em última instância, numa audiência do atual Presidente da CIP, José Mindlin com sua Excia. Ministro da Justiça, Dr. Marcondes Filho, audiência essa que se realizou em 5 de novembro de 1942.

(...) Por motivos óbvios que deixamos de expor nesse relatório, a situação dos 'súditos do Eixo' judeus, não se alterou, até o momento atual. Seria prematuro fazer conjecturas sobre que, quando, e de que forma, poderia ser feita uma revisão da posição legal pela justa apreciação da situação legal, moral e jurídica.

A diretoria lamenta juntamente com aqueles sócios legalmente aqui denominados 'súditos do Eixo' que, não tenha sido possível até agora, alterar-lhes a situação e, espera que futuros esforços sejam cercados de melhor êxito.

Imediatamente após o rompimento das relações diplomáticas do Brasil com os países do Eixo, a Congregação facultou aos seus respectivos sócios, a prova de sua qualidade de vítimas do nazismo e, simultaneamente de sócios de reconhecida organização brasileira - o cartão azul da CIP." 348

Consciente da situação vivenciada pelos refugiados judeus, a CIP procurava manter seus sócios informados sobre todas as medidas idas que haviam sido tomadas pela associação em busca de uma distinção entre súditos nazistas e refugiados judeus. Lamentava-se que, até aquela data, nenhuma de suas atitudes tivesse surtido o efeito esperado. Após meses de impasses e pedidos indeferidos frente ao governo brasileiro, a Congregação iniciou a emissão de "carteiras azuis", uma espécie de documento de identificação que deveria ser portado pelo judeu como forma de comprovar sua "qualidade de vítima do nazismo" e de associado a uma instituição brasileira, desvinculando-o da imagem de "súdito do Eixo". Essa atitude buscava, acima de tudo, remediar os danos psicológicos e morais causados aos judeus pelo estado de guerra brasileiro que, segundo Alice Hirschberg, foram muito maiores do que os danos financeiros ${ }^{349}$. No entanto, a definição para o problema dos “judeus-alemães” brasileiros ocorreria apenas em meados de 1945, com a criação, no Rio de Janeiro, do Comitê Representativo dos Judeus Alemães no Brasil.

Autorizados por João Alberto, Chefe de Polícia e do Departamento Federal de Segurança Pública, as principais associações judaico-cariocas fundaram o referido Comitê, com o objetivo de "representar e defender os interesses dos nossos

\footnotetext{
${ }^{348}$ Crônica Israelita. São Paulo, 5 de dezembro de 1942. Pront. $n^{o}$. 4705, da Congregação Israelita Paulista. DEOPS/SP. APESP. Grifo nosso.

${ }^{349}$ Alice Irene Hirschberg, Op.cit. p. 72.
} 
correligionários de nacionalidade alemã, os quais não obstante a sua origem judaica, foram atingidos pela mesma legislação à qual estão sujeitos os "Súditos do Eixo" 350 . Como ato primeiro, o Comitê propunha que, em caráter de urgência, fosse organizado um registro completo de todos os judeus alemães passíveis de serem atingidos pelo Decreto $n^{\circ}$. 4166. Tal registro seria disponibilizado às autoridades competentes através do Comitê Representativo, para que as mesmas tivessem a possibilidade de descriminar os judeus alemães dos verdadeiros súditos do Eixo.

O Comitê constituía uma espécie de "ponte" entre as demais associações judaico-brasileiras e o governo federal. No questionário veiculado pela entidade eram requeridos todos os dados sobre o judeu e seu cônjuge: os números das carteiras de identidade para estrangeiros e das matrículas em grêmios ou associações judaicas, a data de chegada da família e o porto no qual haviam desembarcado, além da situação do imigrante no país, "Admitido em território nacional em caráter permanente definitivo, ou temporário ou precário?",351. Os questionários preenchidos eram entregues, juntamente com duas fotografias do judeu-alemão, ao Comitê Representativo que os repassava para o Departamento Federal de Segurança Pública. Após analisar os pedidos, o DOPS liberava os beneficiados das restrições policiais às quais estavam submetidos os súditos do Eixo como, por exemplo, a obrigatoriedade do porte do salvo-conduto para viajar e de autorizações para transferir sua residência. Logo, iniciou-se a distribuição de uma "carteira vermelha" que deveria ser portada por todos os judeualemães como prova de não-identificação com os inimigos do Brasil.

Logo no início desse programa, a CIP percebeu que seus filiados poderiam ser beneficiados com a novidade e requereu a autorização do Comitê para enviar-lhe questionários e fotografias. Inicialmente, o Comitê aceitou a remessa de 1.000 questionários paulistas, mas, segundo os cálculos da Congregação, seriam necessários, no mínimo, 2.000 questionários para começar a solucionar os problemas dos judeualemães estabelecidos na cidade de São Paulo.

Ao retornarem para o Rio de Janeiro, os questionários serviam como base para que a Polícia disponibilizasse ao pleiteante a "carteira vermelha" que, em formato padronizado, trazia os seguintes dizeres: "O Sr. Fulano de Tal, cuja fotografia se vê à margem, devidamente carimbada, está isento das formalidades policiais referentes aos

\footnotetext{
${ }^{350}$ Ata de Fundação do Comitê Representativo dos Judeus Alemães no Brasil. Rio de Janeiro, 31 de maio de 1945. Fundo 187/AHJB.

${ }^{351}$ Questionário do Comitê Representativo dos Judeus Alemães no Brasil. S/d. Fundo 187/AHJB.
} 
súditos do Eixo e está autorizado a viajar, por qualquer via, em todo o território nacional" ${ }^{, 352}$.

O documento era assinado pelo próprio João Alberto, Chefe da Polícia Federal, e deveria ser reconhecido em cartório por Djalma da Fonseca Hermes, o único tabelião especialmente autorizado a "abonar" a assinatura de João Alberto. Por semana, eram despachadas pela Polícia Federal cerca de 200 carteiras, das quais, aproximadamente 120, diziam respeito aos judeus radicados em São Paulo.

Podemos perceber que o texto da "carteira vermelha" refletia um dos maiores inconvenientes para aqueles que, até então, eram confundidos com os súditos nazifascistas: a obrigatoriedade dos salvo-condutos. No Departamento de Polícia Política de São Paulo centenas de prontuários foram abertos com o objetivo único de conceder, ou não, os salvo-condutos para indivíduos judeus. $O$ problema concentrava-se, principalmente, em torno de centenas de judeus que trabalhavam como representantes comerciais e, por isso, dependiam de suas viagens para sobreviver ${ }^{353}$.

Apesar de benéfico, o documento não era válido para isentar os bens dos judeualemães das restrições econômicas e do confisco imposto pelo Decreto nº ${ }^{\circ}$ 4166. Além disso, aqueles que não professavam a religião judaica tinham dificuldades para garantir a concessão do documento, precisando comprovar que possuíam descendência israelita. Visando colaborar com aqueles que moravam distantes dos centros de decisão da região sudeste, a CIP se encarregou de enviar questionários para a colônia judaica de Rolândia, no Paraná, comprometendo-se a devolvê-los, já preenchidos, para o comitê carioca. ${ }^{354}$

Ao final de agosto de 1945 ainda havia indivíduos em São Paulo aguardando as remessas de seus cartões. A CIP e o Comitê calculavam então, que seriam necessárias pelo ou menos mais dez semanas até que a situação fosse completamente regularizada $^{355}$. Não obstante, sabemos que em dezembro daquele ano de 1945, a

\footnotetext{
${ }^{352}$ Carta do Comitê Representativo dos Judeus Alemães no Brasil, para a Congregação Israelita Paulista. Rio de Janeiro, 9 de julho de 1945. Fundo. 187/AHJB.

${ }^{353}$ Importante lembrar que muitos destes "representantes comerciais" haviam sido em seus países de origem, advogados, médicos, engenheiros, proprietários de lojas comerciais, dentre outras profissões liberais. Vários desses casos, como o do casal italiano Giorgio e Maria Schraiber, professores universitários que chegando ao Brasil foram contratados como "tratadores de cavalos" na Fazenda de Francisco Matarazzo, foram explorados por Maria Luiza Tucci Carneiro em Brasil, Um Refúgio nos Trópicos: A Trajetória dos Refugiados do Nazi-fascismo. Op.cit. pp. 84-90.

354 Rolândia, no norte do Paraná, desde 1933, abrigava uma representativa comunidade de refugiados judeus alemães que ali compraram terras através de operações com Companhia Paraná Plantations. Maria Luiza Tucci Carneiro em Brasil, Um Refúgio nos Trópicos: A Trajetória dos Refugiados do Nazifascismo. pp.133-138.

${ }^{355}$ Carta do Comitê Representativo dos Judeus Alemães no Brasil, para a Congregação Israelita Paulista. Rio de Janeiro, 24 de agosto de 1945. Fundo 187/AHJB.
} 
Segunda Guerra Mundial chegara ao fim e, portanto, o Brasil não precisaria mais preocupar-se com possíveis súditos do Eixo vagueando por seu território. Naquele mesmo mês, os representantes do Comitê carioca foram chamados à Delegacia Especial de Segurança Política e Social e intimados a devolver todas as carteiras vermelhas que haviam sido distribuídas aos judeu-alemães. A notícia da necessidade de devolução das carteiras causou grande aborrecimento à CIP, constrangida por ter de pedir aos seus sócios a entrega daquele documento:

“(...) A decisão atual traz o perigo de abalar a confiança dos interessados e, por isso, não podemos consentir com essa decisão na sua forma atual. Já formalmente não podemos compreender que direito tem a Delegacia Especial de Segurança Política e Social de recolher documentos emitidos não por essa Delegacia, mas, pelo Chefe de Polícia. $(\ldots), 356$

A Congregação alegou ainda que, considerando-se que o Comitê não possuía sócio algum, constituindo apenas uma Associação responsável por "apresentar certas pessoas às autoridades", não seria correto a mesma comprometer-se a devolver cartões que não poderia recolher por si própria. Assim, diante do medo de retornar à condição de perigosos à Segurança Nacional e, desconfiando das palavras da Delegacia de Segurança Política e Social, a CIP, inicialmente, recusou-se a recolher as "carteiras vermelhas" entregues aos seus sócios, devolvendo apenas, aquelas que ainda não haviam sido repassadas. ${ }^{357}$

A contestação à alcunha de "súditos do Eixo" pode ser entendida como uma ação da comunidade judaico-brasileira contra as disposições arbitrárias do governo Vargas. Classificar essas disposições como atos de um governo irrefutavelmente antisemita, nos lançaria a uma armadilha, pois, não sabemos até que ponto seus efeitos atingiram a comunidade judaica já radicada e, se a mesma acreditou na extensão dos laços anti-semitas no Brasil. A historiografia brasileira tem apresentado, nos últimos anos, uma fervorosa discussão sobre a existência de práticas anti-semitas no Brasil. É indubitável que a diplomacia brasileira em missão no exterior agia em obediência às Circulares Secretas, procurando impedir a entrada de judeus no país. Quanto a esta questão, nos parece que não há mais motivos para discussão. Agora, uma vez radicados no país, quais seriam as reais condições de sobrevivência legadas aos judeus?

\footnotetext{
${ }^{356}$ Carta da Congregação Israelita Paulista para o Comitê Representativo dos Judeus Alemães no Brasil. São Paulo, 28 de dezembro de 1945. Fundo 187/AHJB.

357 Idem.
} 
Autores como Roney Cytrynowicz e Zilda Iokoi defendem que, dentro do Brasil, nunca ocorreu nenhum tipo de manifestação anti-semita, sendo que, muitas vezes, os judeus por serem estrangeiros, acabavam sendo enquadrados em leis que restringiam a atuação política e ideológica de certas categorias de imigrantes ${ }^{358}$. Muitos judeus que chegaram ao Brasil durante as décadas de 1930 e 1940 defendem a mesma opinião. Se considerarmos a falta de documentação oficial referente ao trato específico dos judeus já radicados em território nacional, podemos endossar a opinião de Cytrynowicz e Iokoi, na qual os judeus seriam meras vítimas de circunstâncias cotidianas. Mas, será que não poderíamos avaliar a omissão e a arbitrariedade das autoridades brasileiras como uma forma de exclusão? Constatamos que o Brasil, ao romper suas relações diplomáticas com os países do Eixo em 1942, promulgou o Decreto $\mathrm{n}^{\circ} 4166$ transformando os imigrantes italianos, alemães e japoneses em perigosos à segurança nacional. Dias depois, a comunidade judaico-brasileira tentava junto às autoridades encontrar uma forma de isentar os judeus das disposições do referido decreto. No entanto, a única resposta que obtiveram das autoridades brasileiras transmutou-se em omissão e descaso, provocando o fichamento de centenas de judeus junto ao DEOPS paulista. Em vários casos provocaram prisões e, certamente em todos, medo, insegurança e trauma. Deste modo, talvez não possamos defender a existência de um anti-semitismo explicito e oficial no Brasil, mas, também não devemos ignorar acontecimentos como os descritos acima e tratá-los como se não tivessem ocorrido. Cabe à historiografia contemporânea desfazer esta trama que obstrui o conhecimento histórico e trazer à tona a expressiva documentação produzida pelo Ministério de Justiça e Negócios Exteriores, nos tempos de Francisco Campos e seu secretário Ernani Reis, assim como não devemos omitir as ações anti-semitas de Dulphe Pinheiro Machado junto ao Departamento Nacional de Imigração $^{359}$. Cabe também aos historiadores investigar, junto aos arquivos do Exército, os registros acerca dos refugiados judeus que, provavelmente, foram tratados de forma estereotipada pelos representantes da direita. ${ }^{360}$

\footnotetext{
358 Roney Cytrynowicz. "Além do Estado e da ideologia: imigração judaica, Estado- Novo e Segunda Guerra Mundial." In: Revista Brasileira de História. São Paulo, junho de 2002; Zilda Grícoli Iokoi. Op.cit.

${ }^{359}$ Ver Maria Luiza Tucci Carneiro, O Anti-semitismo na Era Vargas e Cidadão do Mundo: Brasil e a Questão dos Refugiados Judeus (1933-1948), Op.cit.; Fábio Koifman, Op.cit.

${ }^{360}$ Sobre os protestos anti-semitas de diferentes segmentos da Igreja Católica no Brasil já tratou a historiadora Taciana Wiazovski. O Mito do Complô Judaico-Comunista no Pensamento Autoritário Brasileiro: Gênese, Difusão e Desdobramentos, Op.cit.
} 


\section{2 - A CIP e a sociedade brasileira}

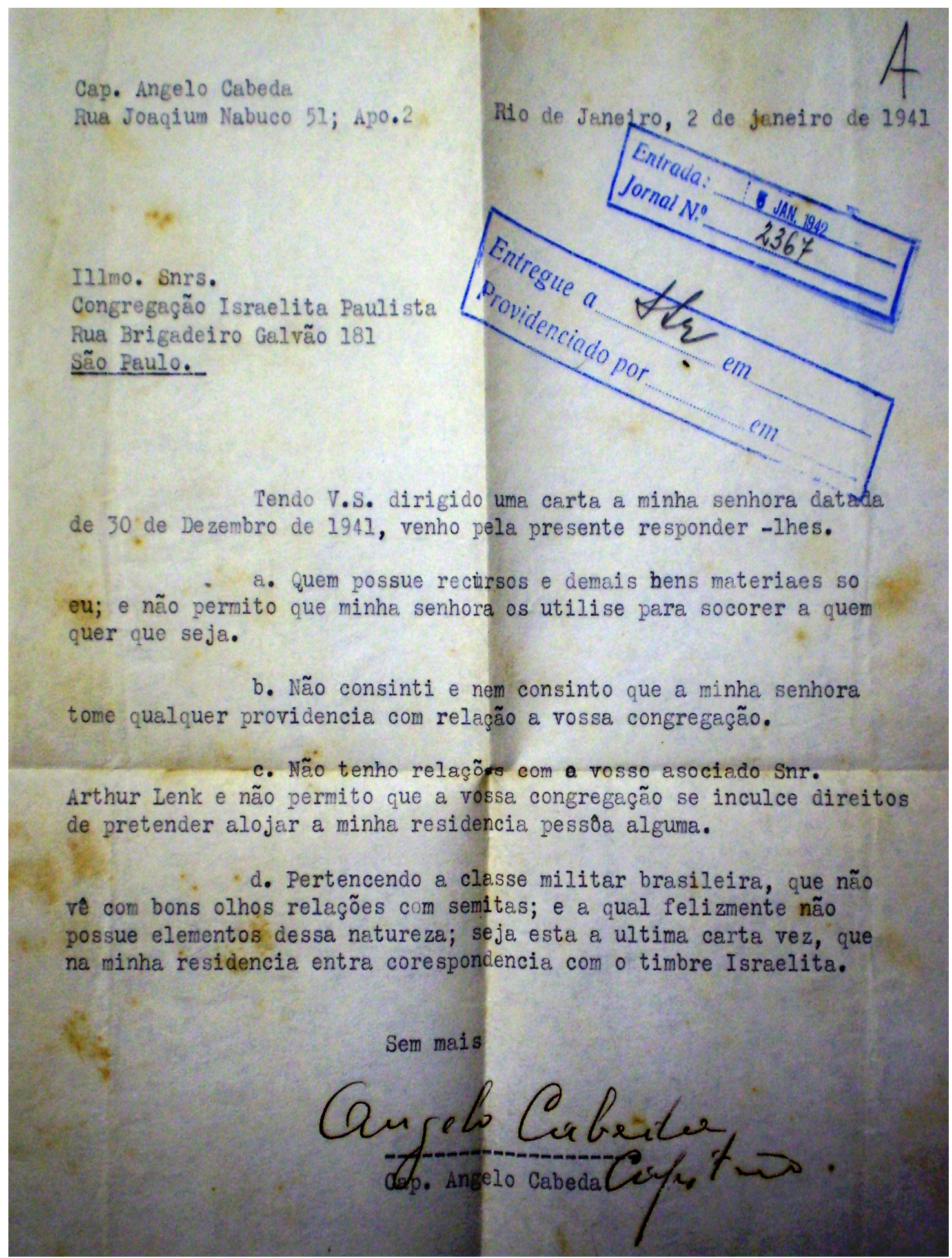

- Carta do Capitão Ângelo Cabeda para a Congregação Israelita Paulista. Rio de Janeiro, 2 de janeiro de 1941. Fundo Lorch/LEER - USP. 
A eclosão da Segunda Guerra Mundial na Europa intensificou a emigração de idosos para qualquer país que lhes concedesse um visto. Nos casos daqueles que chegavam ao Brasil, muitos não conheciam ninguém que os pudesse ajudar. Na maioria dos casos, essas pessoas de idade mais avançada adoeciam ou não conseguiam nenhuma colocação profissional no Brasil. Sua sobrevivência dependia, pois, do auxilio concedido pelas associações beneficentes judaicas. Por causa das constantes dificuldades financeiras e do intenso fluxo de pessoas a serem ajudadas, as associações não raramente tentavam encontrar os parentes ou amigos do imigrante que pudessem assumir suas despesas. Tal era a situação de Arthur Lenk.

Arthur Lenk imigrara para o Brasil no contexto exposto acima. Apesar de possuir três filhos estabelecidos no país, foi amparado pela CIP que supriu suas necessidades em custos médicos, remédios e roupas. Em dezembro de 1940, diante da incapacidade de continuar a arcar com as despesas do Sr. Lenk, a CIP enviou uma carta à sua filha Cudrum Lenk Cabeda, residente no Rio de Janeiro, na tentativa de encontrar alguma solução:

"É completamente impossível para nós sustentar o Sr.Lenk no futuro. Pedimos por isso à V.S. que entre e relações com seus irmãos para arranjar mensalmente os meios que são necessários para a vida de seus pai, trata-se - mais ou menos - de Rs. $300 \$ 000$ (trezentos milréis) por mês.

Caso não resolva isso até o dia 8 de janeiro de 1942, seriamos obrigados a pedir ao Sr. Lenk ir para o Rio de Janeiro para ele viver lá junto com um de seus filhos. Nesse caso seriamos prontos a pagar as despesas de viagem." 361

Dias após este apelo, a CIP recebeu uma resposta assinada não por Cudrum Lenk Cabeda, mas por seu marido, o capitão do exército brasileiro Ângelo Cabeda. Em sua carta, Ângelo expõe sua indignação frente aos pedidos da CIP à sua esposa. Recusase a contribuir com qualquer quantia para a manutenção de seu sogro, e afirma que não autorizaria sua esposa a ajudar o próprio pai. Ao explicar os motivos segundo os quais tomava aquelas atitudes, explicita seu preconceito em relação aos judeus, compartilhado também pelo Exército, pois, “(...) pertencendo a classe militar brasileira que não vê com bons olhos relações com semitas; e a qual, felizmente, não possui elementos dessa natureza... ${ }^{362}$. Desconsiderando que estava casado com uma descendente de judeus, o capitão extrapolou o problema para o seu campo profissional. Certamente estava

${ }^{361}$ Carta da Congregação Israelita Paulista para Sra. Cudrum Lenk Cabeda. São Paulo, 30 de dezembro de 1940. Fundo Lorch/LEER - USP.

${ }^{362}$ Carta do Capitão Ângelo Cabeda para a Congregação Israelita Paulista. Rio de Janeiro, 2 de janeiro de 1941. Fundo Lorch/LEER - USP. 
preocupado com o comprometimento que a presença de Arthur Lenk poderia trazer para a sua família em conseqüência de sua identidade judaica.

Apesar das declarações do Capitão Cabeda, em 1942, a Congregação Israelita Paulista aceitou participar da arrecadação de fundos a fim de presentear a mocidade brasileira com três aviões de treinamento, por ocasião do aniversário do Presidente Getúlio Vargas. Tal iniciativa fora tomada pela associação carioca "Comitê Central de Socorro aos Israelitas Vítimas da Guerra", como forma de homenagear o Presidente da República em nome de todos os judeus que viviam no Brasil. Esta campanha recebeu o título simbólico de "asas para o Brasil" e contava com a participação de todos os grupos e instituições de beneficência judaicas existentes no país:

"Este empreendimento, a ser realizado dentro de um prazo muito curto, é de significação simbólica, dando aos israelitas do Brasil a oportunidade, de por este meio, fazerem chegar ao grande estadista que dirige os destinos desta grande terra hospitaleira a expressão de sua gratidão e de sua irrestrita solidariedade na presente emergência nacional" 363

Em janeiro de 1942 o governo brasileiro havia decidido romper suas relações diplomáticas com os países do Eixo. A declaração de guerra aconteceria meses depois, em agosto. Nesse ínterim, em abril, Getúlio Vargas comemorou seu aniversário e recebeu, como presente, a promessa da doação de aviões de treinamento pela comunidade judaico-brasileira. Essa iniciativa emergiu num momento em que o governo brasileiro reconhecia o nazi-fascismo como seu inimigo também. Essa atitude seguiu então, envolta em gratidão: gratidão pela acolhida e gratidão pelo reconhecimento de um perigo comum. Um ato sintomático da coletividade judaicobrasileira que, apesar de não ignorar as restrições secretas anti-semitas sustentadas pelo Estado brasileiro, aplaude sua postura pró-aliados. Para que um presente tão caro pudesse ser doado a Getúlio Vargas, naquele mês, todas as famílias associadas à CIP depositaram em conta especial, no Banco do Brasil, uma quantia equivalente a duas mensalidades pagas à associação. ${ }^{364}$

Os aviões foram entregues em dezembro daquele mesmo ano e, ao invés de três, a comunidade judaica conseguiu doar cinco aeronaves. No inicio de janeiro de 1943, uma nota de agradecimento expedida pela Presidência da República, e assinada pelo

\footnotetext{
363 Circular de Roberto Lichtenstein, Presidente da Congregação Israelita Paulista, enviada aos sócios. São Paulo, 17 de abril de 1942. Fundo Lorch/LEER - USP.

364 Idem.
} 
próprio Getúlio Vargas, foi publicada na primeira página da Crônica Israelita. Nesse texto, percebemos a tentativa de mostrar um Brasil tolerante a todas as "raças" e "religiões" e profundamente indignado com a situação dos judeus na Europa, provocada pela barbárie nazista:

“(...) O Brasil é um pais aberto a todas as raças, religiões e cultos. (...) Acompanhamos com tristeza a perseguição nazista aos israelitas na Europa (...). Digam aos seus representantes que o Brasil está aborrecido por essas perseguições." 365

Meses depois desse empreendimento, o Brasil reconheceria a situação de beligerância com as nações do Eixo, fato que levaria Alfred Hirschberg, em nome do Conselho da CIP a enviar um telegrama a Getúlio Vargas, em nome de toda a comunidade judaico-paulistana:

"Os milhares de associados da Congregação Israelita Paulista entre os quais numerosos
refugiados vitimados pela barbárie nazista, vêm expressar a v. exa. sua profunda
indignação diante do selvagem e injustificável atentado à soberania brasileira.(...) A
Congregação Israelita Paulista, a pedido dos numerosos refugiados israelitas
inteiramente integrados com os sentimentos do país que lhes deu asilo, nesta hora grave
da nação, vem transmitir a Vossa Excelência a expressão da incondicional solidariedade
dessas primeiras vítimas da opressão totalitária. “366 O "atentado à soberania brasileira" citado por Alfred Hirschberg, dizia respeito ao torpedeamento de embarcações brasileiras por submarinos alemães. Naquele momento, o Brasil havia sido atacado pelo mesmo inimigo que perseguia e dizimava milhares de judeus nos campos de extermínio de Hitler. Esse fato ofereceu a oportunidade para a comunidade judaico-brasileira colocar em pauta a situação dos refugiados judeus, agora solidários com os brasileiros na luta contra um inimigo comum: a barbárie nazista.

Em setembro daquele ano, José Mindlin foi indicado para participar de uma audiência com Alexandre Marcondes Filho, Ministro da Justiça e do Trabalho, com o objetivo de discutir as novas resoluções federais. Tratava-se do Decreto-lei $n^{\circ} .4684^{367}$, que proibia as organizações de caráter cultural ou beneficente de tomarem providências

\footnotetext{
${ }^{365}$ Alice Hirene Hirshberg, Op. cit. p.74.

${ }^{366}$ Ata da Reunião da Assembléia dos Representantes da Congregação Israelita Paulista. São Paulo, 25 de agosto de 1942. Fundo 187/AHJB. Grifo nosso.

${ }^{367}$ Decreto-lei $n^{\circ}$. 4684, de 12 de setembro de 1942. Regula condições para fundação e funcionamento de associações visando quaisquer objetivos de interesse da defesa nacional e dá outras providências.
} 
em prol da defesa nacional sem a prévia autorização do Ministro da Justiça ${ }^{368}$. A CIP visava, com isso, coordenar o envio de alguns de seus membros como voluntários para “o serviço militar, quaisquer outros serviços, fornecimento de sangue, etc." ${ }^{369}$ Nesse contexto, a CIP chegou a disponibilizar uma ficha para o "Alistamento Voluntário para a Defesa do Brasil" ${ }^{\text {,370 }}$, na qual constavam, além de todos os dados do candidato, a assinatura do Presidente da CIP, Ludwig Lorch, com os seguintes dizeres: "Declaro pela presente que coloco-me a disposição das autoridades militares como voluntário para a defesa do Brasil",371.

É possível que informações como essa sequer chegassem ao conhecimento da sociedade brasileira, católica em sua maioria. Pode-se mesmo constatar que alguns segmentos da população continuavam a avaliar a comunidade judaica com desconfiança e pré-conceitos. Em alguns momentos, tais sentimentos extrapolaram o âmbito privado e alcançaram o público leitor do jornal A Gazeta que, em outubro de1942 publicou a notícia "O Perigo", com matéria de primeira página:

"Chegamos ao momento em que o preparo da defesa do Brasil não pode sofrer a menor restrição. Si entramos na guerra, foi porque o imperialismo alemão, auxiliado pela cumplicidade de seus sócios, ameaça a América e, diretamente o Brasil (...). O povo brasileiro está se enfileirando (...) ao lado de nações que, como a Inglaterra e a Rússia, demonstram como a energia e a vontade de um povo unido e corajoso anulam e exterminam a violência dos conquistadores famintos e brutais. (...) Devemos estar de olho vivo contra as infâmias da quinta-coluna. Há inimigos espalhados por aí, de atalaia, e a emprestar ajuda ao nazi-fascismo. (...).

O exercício do "black-out" encerra, além do mais, importância em relação à disciplina e à obediência que mostra o animo patriótico de nosso povo. Os recalcitrantes, justifiquem-se como quiserem, são perniciosos, trabalham para a quintacoluna. Hoje, como nunca, a Alemanha procura debilitar os outros países por meio da espionagem e do derrotismo. (...) Atacar a quinta-coluna, extingui-la em todos os redutos, elimina-la em seus membros - eis o grave imperativo dessa emergência.

Falávamos do "black-out" de ontem. Tanto no bairro do Jardim América, como em vários pontos do perímetro central, judeus alemães, devidamente identificados, persistiram com acinte, em manter suas casas e seus apartamentos iluminados, de modo que a luza irradiava fora. Os jovens encarregados da fiscalização tiveram fadiga insana em advertir os tais súbditos do "eixo" sobre as determinações da II Região Militar, ao que os judeus alemães responderam com a continuação da desobediência. Francamente, é revoltante. Esses indivíduos, cuja presença é nefasta no interior de nossa casa, denunciam maus intuitos e estão acobertados por uma tolerança nossa que precisa acabar. Sob excusa de serem judeus, escondem a realidade de suas

\footnotetext{
368 Ata da Reunião do Conselho das Comissões da Congregação Israelita Paulista. São Paulo, 30 de setembro de 1942. Fundo 187/AHJB.

${ }^{369}$ Idem.

${ }^{370}$ Ofício da Congregação Israelita Paulista para Ludwig Lorch. São Paulo, 15 de outubro de 1942. Fundo 187/AHJB.

${ }^{371}$ Ficha para o Alistamento Voluntário para a Defesa do Brasil. Congregação Israelita Paulista. São Paulo, 1942. Fundo 187/AHJB.
} 
incumbências; e nós de nenhum modo podemos alimentar tanta boa fé que nos venha, depois, causar arrependimentos.

Ponhamos termo à tolerância incompatível com o estado de guerra. Tudo quanto é alemão deve ser vigiado de perto. Nada de casas alemãs rotuladas de nomes nacionais. Nada de instituições em que figurem patrícios de Adolf Hitler. São assaz conhecidas as tramóias da quinta-coluna. (...) Assim com os institutos bancários, com as casas de comércio e com as indústrias, onde remanesce o contágio da lepra nazista.

Liquidemos com o perigo, antes que o perigo nos acometa pelas costas."

Dias antes de esse artigo ser publicado, a II Região Militar havia informado aos moradores de alguns bairros centrais da cidade de São Paulo que realizaria um treinamento de defesa passiva antiaérea, sendo necessário que a população apagasse todas as luzes da região. Eram os exercícios de black-out ocorridos nas principais capitais brasileiras durante a Segunda Guerra Mundial. Os bondes paravam de circular, e as luzes da rua, das casas, dos faróis dos carros e dos centros de comércio eram apagadas para que a Aeronáutica pudesse treinar o enfrentamento de prováveis bombardeios nazi-fascistas. Nesse momento, em que grande parte da população brasileira se mobilizava visando o bem comum, alguns se viam "tomando parte" e atuando ao lado de todo o Brasil contra o inimigo-além-mar. Diante de tal patriotismo, seria normal observar o comportamento dos vizinhos e averiguar se o comprometimento da maioria estaria sendo respeitado por todos.

Em dois momentos da reportagem, o autor elogia as atitudes da Inglaterra e da Rússia. Considerando a defesa a um país comunista e a acusação de quinta-colunista ${ }^{373}$ dirigida à comunidade judaico-paulistana, podemos concluir que a pretensão do autor em relacionar os judeus aos nazistas e não aos comunistas, alusão que ganhara ímpeto no Brasil durante a década de $1930^{374}$. De forma explícita, a comunidade judaica foi acusada de espionagem e de não participar do black-out propositadamente, obstruindo o treinamento simulado da Força Aérea Brasileira que se preparava para um "possível" ataque nazi-fascista. A argumentação tem como centro a suposição de que os judeus estariam se utilizando da desculpa de serem judeus e, assim, passarem despercebidos em meio à população brasileira que os veria simplesmente como vítimas da barbárie de

\footnotetext{
372 Jornal A Gazeta. "O Perigo”. São Paulo, 3 de outubro de 1942. APESP. Grifo nosso.

373 "Quinta coluna" é um termo usado para se referir a grupos clandestinos que trabalham dentro de um país ou região, ajudando na invasão armada promovida por outro país em caso de guerra internacional. Por extensão, o termo é usado para designar todo aquele que auxilia a ação de forasteiros, mesmo quando não há previsão de invasão. A ação de uma quinta coluna não se dá no plano puramente militar. Assim como os demais partícipes de uma guerra, os elementos quinta-colunistas agem por meio da sabotagem e da difusão de boatos.

374 Sobre esse assunto ver: Taciana Wiazovski. O Mito do Complô Judaico-Comunista no Pensamento Autoritário Brasileiro: Gênese, Difusão e Desdobramento, Op. cit.
} 
Hitler. Tradicionais slogans anti-semitas foram empregados para construir a imagem de perigo como, por exemplo, a expressão “cuja presença é nefasta...”, “maus intuitos..." e judeus que "se escondem".

A identificação dos indivíduos judeus com os súditos alemães e com o nazismo, explicitada principalmente no terceiro parágrafo do artigo, não deve ser considerada como isolada do contexto histórico. Durante os anos de 1942 a 1945, até mesmo a Polícia Política, encarregada de "proteger" a população, incorreu em atos anti-semitas ao deter e acusar judeus por práticas nazistas. Uma inversão de valores inadmissível para uma nação que optara por lutar contra o totalitarismo.

Atenta a tais manifestações, a Congregação Israelita Paulista enviou, cinco dias após a publicação desse artigo, uma resposta à direção do jornal A Gazeta, refutando as acusações feitas à comunidade judaica e exigindo retratação pública. A CIP acusava o autor de "anti-semitismo desenfreado", ao igualar os judeus aos seguidores de Hitler e Mussolini. Além disso, em entrevista ao mesmo jornal, o General Maurício Cardoso comentou sobre os resultados do exercício do black-out: "Se falhas houve numa insignificância numérica, não descoloriram o êxito total (...)”, 375.

Não obstante, para Ludwig Lorch o autor do artigo publicado em A Gazeta demonstrava estreiteza ideológica com o nazi-fascismo, já que, expressava opiniões anti-semitas:

"Homens proeminentes já tem manifestado sua opinião de que o anti-semitismo é o primeiro degrau do nacional-socialismo e o sintoma de propensão nazi-fascista. Querer acoimar os inimigos do nacional-socialismo, como os são os israelitas da Alemanha, de quinta-colunistas, só pode partir da intenção de estabelecer confusão na luta clara contra os verdadeiros quinta-colunistas, desviando do verdadeiro perigo da frente interna a boa vontade do povo e atirando-o contra os judeus. “376

As acusações de nazismo feitas aos judeus, durante a Segunda Guerra Mundial, persistiram até o final do conflito, como observamos em outra passagem deste trabalho. No período pós - Guerra e, mais precisamente, após a formação do Estado de Israel, em 1948, um segmento da população brasileira viu-se atormentado pela "fuga de capitais" que estaria ocorrendo devido às constantes doações de dinheiro, alimentos e objetos feitas pela comunidade judaico-paulistana em direção ao novo país. Atenta a esses movimentos, a Polícia Política introduziu esse discurso em vários de seus relatórios,

\footnotetext{
${ }^{375}$ Carta de Ludwig Lorch, Presidente do Conselho da Congregação Israelita Paulista, à Direção do jornal A Gazeta. São Paulo, 8 de outubro de 1942. Fundo Lorch/LEER - USP. Grifo nosso.

${ }^{376}$ Idem.
} 
valendo-se do termo sionista ${ }^{377}$ para acusar a qualquer organização judaica que se dispusesse a colaborar de alguma forma com o recém-criado Estado de Israel. Com atitudes distantes de quaisquer movimentos políticos, porém presentes em todos os tipos de ajuda humanitária, as estratégias utilizadas pela CIP não escaparam à desconfiança policial, principalmente em sua relação com o JOINT, sendo este, tratado pela Polícia como uma "ramificação da corrente sionista." 378.

"Ora, sabido que as posses desses elementos judaicos são grandes no Brasil, notadamente no Rio e São Paulo, a convetibilidade dessas arrecadações irão desfalcar de muito as nossas reservas (...) Afinal, não é justo que esses elementos aqui radicados ganhem fortuna em nosso comércio ou na nossa indústria e, a seguir, prejudiquem-na com transferência sem possibilidade de volta, um intercambio inconveniente. Se os acolhemos e consentimos que se desenvolvessem entre nós(...) não nos parece lícito que desviem seus haveres para outros fins que não os satisfatórios a nossa economia." ${ }^{379}$

A crise econômica sentida no Brasil durante os anos do governo do General Dutra, pode ser um dos motivos pelos quais alguns segmentos da população brasileira, impregnados pelos ideais anti-semitas veiculados no Brasil na década de 1930, insistiam em culpar os judeus pelos eventuais problemas financeiros que afetavam o país. Segundo Thomas Skidmore entre os anos de 1946 e 1949, a política econômica de Dutra mostrou-se "contraproducente", caracterizando-se pela dissipação das reservas cambiais acumuladas durante a Segunda Guerra; pelo aumento das importações associado à capacidade limitada do Brasil para importar; e pelo fracasso do plano SALTE (saúde, alimentação, transporte e energia) ${ }^{380}$. Ou seja, não eram os judeus os responsáveis pelo “desfalque das reservas” brasileiras, mas sim, a própria política governamental.

Nos momentos em que a crise caracterizou a economia brasileira percebemos o resgate, por parte de um segmento da população nacional, de valores anti-semitas que, provavelmente, lhes foram passados por seus pais e avós. Interessante notar que a imputação de culpa aos judeus em questões relacionadas à economia, foi uma das táticas

\footnotetext{
${ }^{377}$ Movimento político que defende o direito à autodeterminação do povo judeu e à existência de um Estado Judaico, por isso sendo também chamado de nacionalismo judaico . Ele se desenvolveu a partir da segunda metade do século XIX, em especial entre os Judeus da Europa Central e da Europa de Leste, sob a pressão de pogroms e do anti-semitismo, crónicos nessas regiões.

${ }^{378}$ Relatório Preliminar sobre as atividades Sionistas em São Paulo. Departamento de Ordem Política e Social. São Pulo, 25 de fevereiro de 1948. Dossiê 30J-30-98 de Organização Sionista do Brasil. DEOPS/SP. APESP.

${ }^{379}$ Relatório do Departamento de Ordem Política e Social de São Paulo. São Paulo, 1 de setembro de 1949. Dossiê 30J-30-98 de Organização Sionista do Brasil. DEOPS/SP. APESP.

380 Thomas Skidmore, Op.cit.
} 
utilizadas por Hitler, entre 1930 e 1940, para convencer a população alemã do "perigo semita". Durante a década de 1970, frente ao colapso econômico causado pelo desgaste da política denominada "Milagre Brasileiro", a culpabilidade dos judeus voltou à tona em uma correspondência recebida pela associação paulista CONIB (Confederação Israelita do Brasil $)^{381}$, da qual a Congregação fazia parte:

"Srs Judeus:

Eu nada teria contra vossa raça, de por acaso não fossem vocês, dentre outros fatores um dos mais importantes fatores inflacionários no Brasil e fora dele.

Reconheço o valor do povo judeu que muito contribuiu para a humanidade, fornecendo aos nossos cientistas as cobaias necessárias aos estudos levados a efeito em nossos campos de concentração no período da II Guerra Mundial. Por isto: obrigado. Infelizmente nem todos puderam ser úteis.

Voltando aos problemas de hoje, eu entenderia que qualquer comunidade de estrangeiros tivesse seu fundo comunitário, para auxiliar seus membros necessitados, mas não posso aceitar de vocês, uma vez que o usam para comprar dólares e enviar a Israel.

Com a compra dos dólares, provocam a especulação monetária. Depois vocês mandam esse dinheiro para Israel, de modo a esvaziar nossa reserva de dólares. Assim fica cada vez mais caro comprar petróleo e outros artigos necessários para mover a sociedade; também dificulta o pagamento, pois precisamos comprar cada vez mais papel moeda. Insuflam assim, a inflação, tornam cada vez mais difícil nossas crianças pobres se alimentarem adequadamente.

Analisando outros aspectos, vocês com suas indústrias, 'nacionais' e multinacionais, suas lojas e demais empreendimentos estão constantemente realimentando a inflação mundial através do controle de preços das matérias-prima e dos produtos industrializados. Por intermédio da expansão na variedade de bens duráveis promovida por vossas indústrias, vocês estão aumentando a necessidade do homem moderno, fazendo declinar a qualidade de vida do mesmo homem, com as poluições produzidas (...)

Estes motivos aqui expostos já são suficientes para decretar: MORTE AOS JUDEUS ${ }^{\text {382 }}$

Este documento foi escrito, provavelmente, entre os anos de 1970 e 1980 (data estimada em função dos outros documentos presentes na seleção). O autor, oculto por suas iniciais, inicia a carta identificando a religião e a cultura judaicas como sinônimos de raça, e prossegue acusando os judeus de serem os grandes culpados por grande parte dos problemas que o Brasil e o mundo enfrentavam naquele momento. Na tentativa de ofender a comunidade judaica o autor, inicialmente, escapa de associações corriqueiras relacionadas ao capitalismo judeu, relembrando as misérias sofridas durante a II Guerra Mundial, como as experiências médicas nazistas, em que seres humanos judeus eram utilizados como cobaias. A seguir ataca a remessa de recursos da comunidade judaica

\footnotetext{
${ }^{381}$ Fundada em 30/05/1948 a CONIB, com sede em São Paulo, foi organizada a partir das iniciativas das comunidades judaicas de São Paulo e Rio de Janeiro.

${ }^{382}$ Carta de M.R.N ao Dr. José Meicheis da Confederação Israelita Brasileira. Série Ordem Política $n^{o}$ 1124: Sionismo. DEOPS/SP. APESP. Grifo nosso.
} 
brasileira para o recém-criado Estado de Israel, apontando esse fator como a causa da situação inflacionária brasileira e da fome de crianças pobres. Posteriormente, através da utilização dos já conhecidos jargões anti-semitas, aponta as indústrias judaicas "nacionais e multinacionais" como as culpadas pela situação inflacionária mundial, pela queda na qualidade de vida do homem moderno e, até mesmo, pela produção de poluição.

É interessante notar o conteúdo da carta associando-o ao momento histórico em que a mesma foi escrita: cerca de 20 anos após os acontecimentos principais apresentados nesse trabalho. Ou seja, mesmo com a revogação de toda a legislação antisemita, no imaginário coletivo de alguns segmentos da população brasileira a questão judaica perdurou por muito tempo, atravessou a ditadura militar e, em função do ressurgimento de tantos grupos neo-nazistas, continua bem atual. 


\section{CONSIDERAÇÕES FINAIS}

A partir do inicio do século XX e, mais precisamente, após o fim da Primeira Guerra Mundial, os governos europeus se viram atormentados pela questão das minorias étnicas e religiosas. Os Tratados de Paz que definiram a formação de muitos Estados Nacionais na Europa, não levaram em consideração as idiossincrasias de cada cultura, agrupando povos distintos num mesmo território. Esta atitude favoreceu o fortalecimento do racismo e da xenofobia em muitos países europeus. ${ }^{383}$ Constituindo uma minoria histórica, os judeus acreditavam que o inicio do século XX lhes traria novas condições de sobrevivência, possibilitando sua ascensão política, econômica e social.

No caso especifico alemão, o anti-semitismo, que nunca deixara de existir, tornara-se mais forte durante e depois da Primeira Guerra Mundial. Segundo Gershom Scholem, nessa época, a literatura anti-semita na Alemanha era vasta, abrangendo desde livros a periódicos e revistas “(...), nos quais se propagava, com toda a clareza e sem deixar margem a mal-entendidos, o que os nazistas colocaram em prática vinte anos depois, com a ascensão de Hitler ao poder." ${ }^{384}$ Por sua vez, a comunidade judaica acreditava que poderia assimilar-se ao conjunto da população "ariana" e procurava não se preocupar com manifestações anti-semitas que acreditavam ser isoladas.

Nesse contexto, em 1933, Hitler ascendeu ao poder na Alemanha sob a égide da política totalitária e nazi-fascista. Aproveitando-se do anti-semitismo em voga e da grave crise econômica pela qual passava o país, transformou os judeus nos "inimigos objetivos" da nação alemã. Inicialmente, espoliou esses cidadãos de todos os seus bens materiais e de sua dignidade. Por fim, decidiu resolver "o problema" através das deportações e do extermínio.

Vítimas principais do regime de terror hitlerista, milhares de judeus dependiam da fuga da Europa para sobreviver. O continente americano e, conseqüentemente o Brasil, emergiam, nesse momento, como uma possibilidade de refúgio e recomeço. Emigrar era muito difícil, pois, principalmente após 1939, o regime de Hitler impedia que os judeus saíssem dos territórios dominados pelo nazi-fascismo. Além disso, em muitos casos, a concessão de vistos estava atrelada ao depósito de determinadas

\footnotetext{
${ }^{383}$ Hannah Arendt. Op.cit.

${ }^{384}$ Gershom Scholem. De Berlim à Jerusalém. São Paulo: Perspectiva, 1991. p. 60.
} 
quantias no banco nacional do país, o chamado "visto capitalista" e, mesmo quando essa autorização de entrada em um país era conseguida, restava ainda garantir os recursos necessários para as passagens e o sustento do emigrante. Não obstante, o problema das minorias já havia ultrapassado as barreiras continentais européias e alcançado muitos países nas Américas, cuja elite intelectual e política consumiam avidamente títulos xenófobos e anti-semitas produzidos e enviados pelo outro lado do atlântico.

Na década de 1930, Gustavo Barroso traduziu para o português a obra antisemita, originalmente russa, "Os protocolos dos Sábios de Sião”, na qual os judeus eram tidos como seres humanos maquiavélicos que pretendiam dominar a economia, a política e a sociedade mundial. Nesse mesmo período, no Brasil, um segmento da comunidade judaica defendia os ideais de igualdade comunistas, publicava seus "escritos subversivos" e se reunia para discutir os teóricos de esquerda e a situação atual do país. Muitos desses homens e mulheres chegaram a ser presos sob a acusação de comunismo e subversão ${ }^{385}$. Logo, as preferências ideológicas de alguns se prestaram para rotular todos os membros da coletividade judaico-brasileira como propagadores do credo comunista. O anti-semitismo no Brasil havia encontrado o seu subterfúgio e a Polícia Política seria a responsável por agir em nome da segurança nacional.

Getúlio Vargas (1930-1945) foi o presidente que instituiu as diretrizes antisemitas em nível nacional, transformando certos argumentos racistas em política de estado. Ansiando por livrar o país do perigo comunista e construir um Brasil branco e europeu, Vargas tratou de impedir a imigração daqueles que não se enquadravam em seu projeto étnico e político. Acordando com alguns dos ideais disseminados pelo nacional-socialismo, a alta cúpula do governo federal brasileiro concluiu que os judeus estavam entre aqueles que seriam improdutivos e dispensáveis para a composição da população brasileira. Apesar de brancos e europeus, os judeus contribuíam para a formação de quistos na sociedade, recusavam-se à assimilação, mantinham práticas religiosas e sociais próprias e instalavam-se preferencialmente nas grandes cidades, competindo por empregos com os naturais do país e recusando-se a participar da colonização agrícola que tinha espaço naquele momento.

Como medidas práticas que afastassem esses indivíduos do território brasileiro foram adotadas políticas de cotas à imigração, cartas de chamada e Circulares Secretas. O problema principal, no entanto, foi mais a época em que tais medidas foram tomadas

${ }^{385}$ Sobre este tema ver Taciana Wiasovski, Bolchevismo e Judaísmo, A Comunidade Judaica sob o Olhar do DEOPS, Op.cit. 
do que o embasamento anti-semita presente nelas. Praticamente nesse mesmo período, entre 1934 e 1945, ocorria na Europa a maior perseguição a um povo da História Contemporânea e, o povo perseguido, era exatamente aqueles mesmos judeus que a legislação imigratória brasileira procurava afastar. Nesse sentido, o que seria mais importante? A composição étnica brasileira ou o salvamento de milhares de homens, mulheres e crianças prestes a serem enviados aos campos de extermínio nazistas?

Foi exatamente nesse contexto em que foram fundadas em São Paulo as principais associações beneficentes judaicas, muitas em funcionamento até hoje, como é o caso da CIP, nosso principal foco de análise. Estas instituições surgiram, inicialmente, como uma forma de suprir as lacunas do estado brasileiro no trato dos refugiados judeus que conseguiam chegar ao Brasil, recebendo-os, amparando-os e oferecendo-lhes o conforto material e espiritual necessários a todos os que vivenciaram experiências traumáticas. Os emigrantes eram recebidos logo no momento do desembarque, no porto de Santos, por representantes da CIP. Trazidos para a capital paulistana, eram encaminhados aos cursos de português e recebiam auxilio financeiro para que pudessem sustentar a si e às suas famílias durante os meses de adaptação. Aqueles que conseguiam superar as dificuldades iniciais e reconstruir suas vidas devolviam o empréstimo feito pela Congregação e filiavam-se a essa instituição, contribuindo mensalmente com quantias que possibilitariam auxiliar outros imigrantes. A solidariedade formava, assim, uma corrente invisível e infinita.

Conforme piorava a situação na Europa, os líderes da comunidade judaica perceberam que não bastaria apenas receber os que chegavam: seria preciso também possibilitar a fuga daqueles que ainda estavam em meio ao terror hitlerista. Acordos com associações internacionais, como o ocorrido entre a CIP e o JOINT, o incremento de campanhas unidas, a fabricação de falsas cartas de chamada e a constante busca por informações sobre a situação dos judeus na Europa foram as ferramentas que possibilitaram à comunidade judaico-paulistana uma atuação positiva e bem sucedida frente aos desafios impostos pela perseguição nazi-fascista e a legislação varguista.

Contudo, em sua trajetória, essas associações esbarraram com a vigilância e com a desconfiança da Polícia Política de Vargas, convivendo com idas ao DEOPS, pedidos de autorização para a realização de festas e reuniões e visitas surpresa de investigadores. Seus dirigentes e associados tampouco escaparam da repressão imposta pela Polícia: foram presos, fichados, cerceados em seu direito fundamental de ir e vir e proibidos de manifestar sua língua e cultura livremente. 
A eclosão da Segunda Guerra Mundial e o posterior alinhamento do Brasil aos países aliados em 1942, ofereceu ao governo Vargas e à Polícia um novo "inimigo": o nazi-fascismo. A palavra de ordem do DOPS entre 1942 e 1945 centrou-se na caça aos núcleos imigrantes alemães e italianos que, possivelmente, abrigariam os defensores da ideologia de Hitler. Porém, constituída por refugiados, em sua grande maioria, de países como Alemanha, Áustria, Polônia e Itália, a comunidade judaico-brasileira logo retornou à zona de alvo das investidas policiais. Dessa vez, confundida com os alemães nazistas, se viu humilhada com prisões arbitrárias sob a acusação de se manifestarem a favor do Eixo ou defenderem os ideais nazi-fascistas. Naqueles anos sombrios, os judeus estiveram proibidos de viajar ou transferir sua residência; temiam que alguém os visse conversar em seu idioma natal e, acima de tudo, atemorizavam-se com a possibilidade de serem confundidos com os homens que haviam autorizado o massacre de seus parentes e amigos na Europa Central e do Leste.

Foram muitas as atitudes tomadas pela comunidade judaica e, especialmente pela CIP, na tentativa de desfazer essa aparente confusão e isentar os judeus das investidas policiais. No entanto, assistimos ao pouco caso das autoridades, para as quais qualquer atitude oficial no sentido de diferenciar judeu-alemães de alemães nazistas seria impossível e desnecessária. ${ }^{386}$ Apesar de ciente da injustiça enfrentada pela comunidade judaica radicada no país, o governo brasileiro se absteve de qualquer resolução. Enquanto isso, em âmbito externo, continuava sua política de orientação aos cônsules em missão na Europa para que os passaportes de emigrantes judeus não fossem, de modo algum, vistados.

O término da Segunda Guerra Mundial, em 1945, não trouxe fim ao problema da questão judaica nos países europeus e, tampouco o fez a fundação do Estado de Israel. Nesse sentido, mesmo nos anos pós-guerra, o auxilio àqueles que haviam conseguido sobreviver à Hitler ainda era indispensável. Os judeus continuavam sua luta em busca de um recomeço; muitos países europeus não os aceitavam e, aqueles que possuíam parentes em outros continentes acreditavam que seria mais interessante unir-se a eles do que imigrar para Israel.

Nessa mesma época, chegava ao fim o Estado Novo, reconhecido pela historiografia brasileira como o ponto alto da política oficial anti-semita. A substituição

\footnotetext{
386 Opinião do Ministro Alexandre Marcondes Filho sobre a questão dos judeus "súditos do Eixo". Informações Reservadas para conhecimento da Diretoria e Comissão de Relações Públicas da Congregação Israelita Paulista. s/d. Fundo Lorch/LEER - USP.
} 
de Vargas frente à Presidência da República, no entanto, não implicou em mudanças significativas na legislação referente à questão judaica. O governo de Eurico Gaspar Dutra persistiu com as determinações que visavam afastar os refugiados judeus do território nacional. Em um momento no qual os campos de concentração nazistas eram abertos e deslocados de guerra vagavam sem rumo através dos países europeus, o Brasil, mais uma vez, fechava as suas fronteiras. Não obstante, dessa vez não era mais possível alegar desconhecer o drama vivenciado pelos judeus na Europa: a Segunda Guerra já havia acabado e os acontecimentos do Holocausto haviam chegado ao conhecimento de todos.

Nesse contexto, a CIP iniciou uma nova etapa em seu programa de assistência social que incluía: a remessa de objetos, alimentos e roupas aos judeus deslocados de guerra; tentativas de reunir famílias despedaçadas, procurando por parentes e amigos daqueles que já se encontravam radicados no Brasil e dos que ainda estavam na Europa; e a formação de Comitê Auxiliar do JOINT em São Paulo, especializado em lidar com a situação dos refugiados no pós-guerra. Em conjunto com outras associações judaicobrasileiras e internacionais, como a ARI, a UNIAO e o próprio JOINT, a CIP continuava tentando trazer para o Brasil o maior número possível de judeus. Driblando a legislação imigratória brasileira e convivendo com uma constante falta de recursos, a Congregação teve ativa participação na reconstrução da vida de muitas famílias judias radicadas da capital paulistana.

Em 1948, a fundação do estado de Israel suscitou novas possibilidades aos refugiados na Europa e novos desafios à comunidade judaica mundial. Coube à CIP e às outras associações judaico-paulistanas incrementar suas campanhas e ampliar a arrecadação de recursos, visando enviar auxilio também para o novo estado. Contudo, em um aspecto específico, a formação de Israel representou um duro golpe para a Congregação: a expansão da ideologia sionista consolidou, entre a comunidade judaica, a idéia de que quaisquer doações que fossem feitas deveriam ser direcionadas ao recémformado estado judeu. Deste modo, instituições anti-sionistas como o JOINT e a própria CIP que, dependiam de doações da comunidade judaica para sobreviver, se viram em meio a uma falta de recursos crônica. Além disso, muitos não aceitavam que suas doações servissem para ajudar aos judeus deslocados da Europa, acreditando que o Estado de Israel estivesse mais necessitado de auxilio. No Brasil, a fundação da Federação Israelita do Estado de São Paulo (FISESP), reunindo diversas associações 
paulistanas, inclusive as sionistas, provocou o desvio de verbas que anteriormente seriam destinadas à CIP e ao Comitê Auxiliar do JOINT.

Desde então, os judeus não são mais tidos pelo governo federal como subversores da ordem; a maioria conseguiu oferecer aos seus filhos e netos a respeitabilidade e as condições de sobrevivência com as quais sonharam; e os cônsules brasileiros em missão no exterior não condicionam mais a concessão de vistos ao fato de o individuo ser judeu ou não. Atualmente, o governo brasileiro tem demonstrado encarar de outra forma o desenvolvimento da comunidade judaica e, em alguns aspectos, tem procurado aprender com a ideologia de vida e os preceitos legados pelo judaísmo. Muitas das políticas sociais promovidas pelo governo paulista, em nível estadual e municipal, tem fundamento na beneficência e solidariedade judaicas. Entre 2000 e 2001, o governo do estado paulista procurou por representantes da Instituição Beneficente Israelita "Ten Yad"387 - reconhecida em nível federal como uma das 50 instituições beneficentes mais importantes do país - a fim de elaborar um programa para combater a fome da população urbana e desempregada. Estabeleceu-se, então, uma parceria entre a instituição e a Secretaria de Agricultura e Abastecimento do Estado, inaugurando em abril de 2002 um restaurante popular conhecido por "Bom Prato". 388

Em nível municipal, Floriano Pesaro, descendente de judeu-italianos e atual Secretário de Assistência e Desenvolvimento Social da cidade de São Paulo, em entrevista coletiva com diversos órgãos da Imprensa Judaica, explicou que, pela primeira vez, as organizações sociais judaicas estavam sendo tratadas "como um ponto estratégico no desenvolvimento da política social em São Paulo”. ${ }^{389}$ O Secretário frisou ainda que um dos conceitos judaicos que ele introduziu em seu trabalho foi o da tsedaká, uma noção de justiça social que visa substituir a esmola e, cuja idéia ele adotou no nome de sua campanha "Dê mais que esmola, dê futuro." 390 As entidades beneficentes judaicas foram convidadas, por Pesaro, a formar um convênio com a prefeitura a fim de trazer patrocinadores ao projeto e transmitir sua experiência.

Àqueles que foram perseguidos, humilhados e até mesmo confundidos com nazistas, resta o consolo de observar que sua obra beneficente e seus ensinamentos de

\footnotetext{
${ }^{387}$ Instituição judaica-beneficente, fundada em 1992, e atuante no combate à fome e à miséria.

${ }^{388}$ Informe da Instituição Beneficente Israelita “Ten Yad”. São Paulo, 2002.

389 "Floriano Resaro faz balanço da gestão". In: A Tribuna Judaica. São Paulo, 20 de abril de 2008. Ano IX, n'211. p.12.

${ }^{390}$ Idem.
} 
solidariedade ao próximo, não só não foram esquecidos como, hoje, são apreciados e copiados pelo mesmo poder público que tentou impedir sua entrada no Brasil. 


\section{FONTES}

\section{Policiais: Fundo DEOPS/APESP}

\section{Prontuários}

- $20403 \quad$ Adolfo Weill

- 45885 Alfred Ettlinger

- 23074 Alfred Hirschberg

- 74897 Charlotte Hamburger

- 4705 Congregação Israelita Paulista.

- $33807 \quad$ Ernst Wolff

- $36002 \quad$ Frederico Zausmer

- $38006 \quad$ Fritz Pinkuss

- 11268 Geza Reichman

- 44006 Guilherme Krausz

- 20505 Herbert Cohn.

- $59120 \quad$ Luiza Klabin Lorch

- $53569 \quad$ Movimento dos Alemães Livres

- 51379 Nicolau Manoel Kaufman.

- 45244 Rudolf Joseph

- 69353 Salo Wissman

- 1182 Sociedade Israelita de Beneficência e Proteção aos Imigrantes "EZRA".

\section{Dossiês}

- 41-B-50 Alfred Hirschberg

- 30J-30-98 Organização Sionista do Brasil.

- 50-J-67 Sociedades Estrangeiras

$\bullet$

Série Ordem Política

- $1124 \quad$ Sionismo

\section{Periódicos}

- Jornal A Gazeta. “O Perigo”. São Paulo, 3 de outubro de 1942. 


\section{AHJB: Arquivo Histórico Judaico-Brasileiro}

\section{Fundo 187-Congregação Israelita Paulista}

\section{Atas}

- Ata da Reunião do Conselho das Comissões da CIP. São Paulo, 1 de agosto de 1938.

- Ata da Sessão dos Representantes em conjunto com a Diretoria. São Paulo, 20 de agosto de 1939.

- Ata da reunião da Assembléia dos Representantes da CIP. São Paulo, 6 de setembro de 1939.

- Ata da Reunião da Assembléia dos Representantes da CIP. São Paulo, setembro de 1939.

- Ata da Reunião da Diretoria da Congregação Israelita Paulista. São Paulo, 22 de novembro de 1939.

- Ata da Reunião da Assembléia dos Representantes da Congregação Israelita Paulista. São Paulo, 25 de agosto de 1942.

- Ata da Reunião do Conselho das Comissões da Congregação Israelita Paulista. São Paulo, 30 de setembro de 1942

- Ata da Reunião do Conselho das Comissões da Congregação Israelita Paulista. São Paulo, 5 de outubro de 1944.

- Ata de Fundação do Comitê Representativo dos Judeus Alemães no Brasil. Rio de Janeiro, 31 de maio de 1945.

- Ata da Reunião da Diretoria da Congregação Israelita Paulista. São Paulo, 12 de junho de 1945 .

- Ata da Reunião da Diretoria da Congregação Israelita Paulista. São Paulo, 19 de junho de 1945.

- Ata da Reunião da Diretoria e Presidentes das Comissões da Congregação Israelita Paulista. São Paulo, 21 de maio de 1946.

- Ata da Reunião da Diretoria e Presidentes das Comissões da Congregação Israelita Paulista em conjunto com os representantes do Comitê Auxiliar do JOINT. São Paulo, 27 de junho de 1946.

- Ata da Reunião da Assembléia dos Representantes da CIP. São Paulo, 18 de novembro de 1946.

- Ata da Sessão Plenária da Câmara dos Deputados do Distrito Federal brasileiro. s/d, 1947.

\section{Cartas}

- Carta do Comitê Representativo dos Judeus Alemães no Brasil, para a Congregação Israelita Paulista. Rio de Janeiro, 9 de julho de 1945. 
- Carta do Comitê Representativo dos Judeus Alemães no Brasil, para a Congregação Israelita Paulista. Rio de Janeiro, 24 de agosto de 1945.

- Carta da Congregação Israelita Paulista para o Comitê Representativo dos Judeus Alemães no Brasil. São Paulo, 28 de dezembro de 1945.

- Carta de Leni Cahn, Chefe do Departamento de Emigração do Comitê JOINT de Berlim, para o Comitê Auxiliar do JOINT de São Paulo. Berlim, 18 de julho de 1947.

- Carta de J. Sachs, Diretor Executivo do Comitê Auxiliar do JOINT de São Paulo, para o Comitê Auxiliar do JOINT de Estocolmo, Suécia. São Paulo, 21 de maio de 1948.

- Carta de J. Sachs, Diretor Executivo do Comitê Auxiliar do JOINT de São Paulo, para o Comitê Auxiliar do JOINT de Louvain, Bélgica. São Paulo, 5 de julho de 1948.

- Carta de J. Sachs, Diretor Executivo do Comitê Auxiliar do JOINT de São Paulo, para o Comitê Auxiliar do JOINT de Roma, Itália. São Paulo, 5 de julho de 1948.

- Carta de J. Sachs, Diretor Executivo do Comitê Auxiliar do JOINT de São Paulo, para o Comitê Auxiliar do JOINT de Praga, Tchecoslováquia. São Paulo, 6 de julho de 1948.

- Carta de J. Sachs, Diretor Executivo do Comitê Auxiliar do JOINT de São Paulo, para o Comitê Auxiliar do JOINT de Estocolmo, Suécia. São Paulo, 29 de julho de 1948.

- Carta de J. Sachs, Diretor Executivo do Comitê Auxiliar do JOINT de São Paulo, para o Comitê Auxiliar do JOINT de Estocolmo, Suécia. São Paulo, 18 de agosto de 1948.

- Carta de Charles Radvany, do Comitê Auxiliar do JOINT de Budapeste, para o Comitê Auxiliar do JOINT de São Paulo. Budapeste, 22 de setembro de 1948.

- Carta de Nelly Bondy, em nome do Comitê Auxiliar do JOINT de Paris, para o Comitê Auxiliar do JOINT de São Paulo. Paris, 25 de novembro de 1948.

- Carta de J. Sachs, Diretor Executivo do Comitê Auxiliar do JOINT de São Paulo, para o Comitê Auxiliar do JOINT de Roma, Itália. São Paulo, 24 de janeiro de 1949.

- Carta de J. Sachs, Diretor Executivo do Comitê Auxiliar do JOINT de São Paulo, para o Comitê Auxiliar do JOINT de Roma, Itália. São Paulo, 10 de fevereiro de 1949.

- Carta de Elka Eliaskevic, do AJDC Emigrants Bureau, para o Comitê Auxiliar do JOINT de São Paulo. Roma, 7 de março de 1949.

- Carta de J. Sachs, Diretor Executivo do Comitê Auxiliar do JOINT de São Paulo, para o Comitê Auxiliar do JOINT de Estocolmo, Suécia. São Paulo, 11 de maio de 1949.

- Carta de J. Sachs, Diretor Executivo do Comitê Auxiliar do JOINT de São Paulo, para o Comitê Auxiliar do JOINT do Rio de Janeiro. São Paulo, 12 de maio de 1949.

- Carta de Tadeusz Lurie, Secretário Geral do Comitê Auxiliar do JOINT do Rio de Janeiro, para J. Sachs, Diretor Executivo do Comitê Auxiliar do JOINT de São Paulo. Rio de Janeiro, 16 de maio de 1949. 
- Carta de Tadeusz Lurie, Secretário Geral do Comitê Auxiliar do JOINT do Rio de Janeiro, para o Comitê Auxiliar do JOINT de São Paulo. Rio de Janeiro, 25 de julho de 1949.

- Carta de Moses A. Leavitt, Vice-Presidente Executivo do American Jewish JOINT Distribution Committee, em Nova York, para Salo Wissmann. Presidente do Comitê Auxiliar do JOINT em São Paulo. Nova York, 6 de dezembro de 1951.

- Carta de Hans Hamburger, Diretor Executivo do Comitê Auxiliar do JOINT em São Paulo, para o American Jewish JOINT Distribution Committee de Nova York e Paris. São Paulo, 15 de abril de 1952.

- Carta do American Jewish JOINT Distribution Committee de Paris, para Hans Hamburger, Diretor Executivo do Comitê Auxiliar do JOINT em São Paulo. Paris, 6 de maio de 1952.

\section{Comunicados}

- Comunicado de Emanuel Rosen, Diretor Associado do American Jewish JOINT Distribution Committee, de Buenos Aires, para Beatrice Vuncan, Diretora do American Jewish JOINT Distribution Committee de Viena, Áustria. Buenos Aires, 25 de janeiro de 1952.

\section{Fichas/Questionários}

- Questionário do Comitê Representativo dos Judeus Alemães no Brasil. s/d.

- Ficha para o Alistamento Voluntário para a Defesa do Brasil. Congregação Israelita Paulista. São Paulo, 1942.

\section{Informes}

- Informe da Congregação Israelita Paulista. São Paulo, 21 de outubro de 1948.

\section{Memorandos}

- Special Inter-office Memo $n^{\circ} 41$, de Charles H. Jordan. American JOINT Distribution Committee, Paris/França. Paris, 13 de novembro de 1948.

\section{Ofícios}

- Ofício da Congregação Israelita Paulista para Ludwig Lorch. São Paulo, 15 de outubro de 1942.

\section{Panfletos}

- Panfleto "O que é e o que faz o Comitê Auxiliar do JOINT de São Paulo”. São Paulo, 1946.

\section{Periódicos}

- Crônica Israelita 10 anos. Dezembro de 1946. Dez Anos de Construção da Congregação Israelita Paulista. 


\section{Prontuários}

- Adolf Schiller: Secção de Serviço Social da Congregação Israelita Paulista; Casos atendidos - 1939 a 1946.

\section{Protocolos}

- Protocolo da Sessão da Diretoria da Congregação Israelita Paulista. São Paulo, 12 de maio de 1938.

- Protocolo da Sessão da Assembléia dos Representantes da Congregação Israelita Paulista. São Paulo, 29 de janeiro de 1939.

- Protocolo da Sessão da Assembléia dos Representantes da Congregação Israelita Paulista. São Paulo, 12 de novembro de 1939.

\section{Relatórios}

- Relatório do Conselho sobre as Atividades da Congregação Israelita Paulista de 1945 a 1947. São Paulo, 18 de dezembro de 1947.

- Relatório enviado por Edward M.M. Warburg, Presidente do American Jewish JOINT Distribution Committee, em Nova York, para o Comitê Auxiliar do JOINT de São Paulo. Nova York, 25 de maio de 1951.

\section{Fundo Alfred Hirschberg}

\section{Boletins}

- Boletim no. 1 da Campanha de 1946 do Comitê Auxiliar do JOINT. São Paulo, setembro de 1946.

- Boletim n'. 3 "Se sua sorte fosse esta...?"da Campanha de 1946 do Comitê Auxiliar do JOINT.

\section{Panfletos}

- Panfleto ilustrando o progresso do trabalho do JOINT Distribution Committee de 1946 a 1948.

\section{Relatórios}

- Para que tornem a viver. Relatório Anual de 1945 do JOINT Distribution Committee. São Paulo, outubro de 1946.

- The JDC Story, 1914-1952, por Moses A. Leavit, Vice- Presidente Executivo do JOINT Distribution Committee.

\section{Fundo Ludwig Lorch - LEER/USP}

\section{Atas}

- Ata da Reunião a respeito dos fundos da Campanha de 1941. São Paulo, 16 de novembro de 1942. 
- Ata da Reunião do Comitê Auxiliar do JOINT de São Paulo. São Paulo, 13 de julho de 1948.

\section{Cartas}

- Carta da Família Klabin para a Diretoria da Congregação Israelita Askenasi. São Paulo, 26 de dezembro de 1924.

- Carta de José Mindlin para Ludwig Lorch, Presidente da Congregação Israelita Paulista. São Paulo, 25 de novembro de 1937.

- Carta de Ludwig Lorch para Paul Baerwald, Presidente do American Jewish JOINT Distribution Committee, Cidade de Nova York. São Paulo, 19 de maio de 1939.

- Carta de Betti Katzenstein, Representante da Comissão da Colônia de Férias da Congregação Israelita Paulista para a Diretoria da Congregação Israelita Paulista. São Paulo, 2 de dezembro de 1940.

- Carta da Congregação Israelita Paulista para Sra. Cudrum Lenk Cabeda. São Paulo, 30 de dezembro de 1940.

- Carta do Capitão Ângelo Cabeda para a Congregação Israelita Paulista. Rio de Janeiro, 2 de janeiro de 1941.

- Carta de Ludwig Lorch para Frederick W. Borchard c/o para American Jewish JOINT Distribution Committee, Cidade de Nova York. São Paulo, 31 de maio de 1941.

- Carta de Frederick W. Borchard, para Ludwig Lorch c/o para American Jewish JOINT Distribution Committee, Cidade de Nova York. Nova York, 15 de setembro de 1941.

- Carta de Robert Pilpel, do American Jewish JOINT Distribution Committee para Hans Hamburger. Nova York, 28 de Janeiro de 1942.

- Carta de Alfred Jaretzki Jr., Presidente do Sub-Comitê de Ajuda aos Refugiados nas Américas do Sul e Central, para Ludwig Lorch e Salo Wissman. Nova York, 6 de fevereiro de 1942.

- Carta de Hans Hamburger para o American Jewish JOINT Distribution Committee, em Nova York. São Paulo, 8 de março de 1942.

- Carta de Ludwig Lorch, Presidente do Conselho da Congregação Israelita Paulista para o Exmo. Senhor Doutor Ministro da Justiça e Negócios do Interior. São Paulo, 23 de março de 1942.

- Carta de Ludwig Lorch, Presidente do Conselho da Congregação Israelita Paulista, à Direção do jornal A Gazeta. São Paulo, 8 de outubro de 1942.

- Carta de Hans Hamburger, do Comitê Representativo do Interesse dos Judeus Alemães no Brasil, para o JOINT. São Paulo, 24 de setembro de 1946.

- Carta de Ludwig Lorch, Presidente da Congregação Israelita Paulista, para o Presidente do Conselho de Imigração e Colonização. s/d. 


\section{Cartões e Propagandas}

- Cartão de doação enviado pela CIP aos seus sócios e correligionários. São Paulo, 1938.

- Cartão distribuído pela Congregação Israelita Paulista durante a Campanha de 1941.

- Livreto “Que podemos fazer hoje?” distribuído pela Congregação Israelita Paulista em 1941.

- Fazenda Embaré. Propaganda da Colônia de Férias para arrecadação de fundos das férias de 1942/1943. São Paulo, 1942.

\section{Circulares}

- Circular de Roberto Lichtenstein, Presidente da Congregação Israelita Paulista, enviada aos sócios. São Paulo, 17 de abril de 1942.

\section{Comunicados}

- Comunicado de Eduardo Levy, Presidente da Associação Religiosa Israelita do Rio de Janeiro, aos sócios. Rio de Janeiro, 8 maio de 1942.

- Comunicado de Paul Zander, Presidente da "União", Associação Beneficente Israelita, aos sócios. Rio de Janeiro, maio de 1942.

\section{Cópias}

- Cópia da resposta de E. Koch, Presidente da Assembléia dos Representantes da Congregação Israelita Paulista, à carta de 13 de janeiro de 1943 do Movimento dos Alemães Livres do Brasil. São Paulo, s/d.

- Cópia da Ata de Assembléia dos Representantes da Congregação Israelita Paulista. São Paulo, 1941.

\section{Currículos}

- Currículos de Hermann Merzbacher e Kurt Roth. Congregação Israelita Paulista. São Paulo, 24 de abril de 1940.

- Currículo de M. Schwartzman e Heinz Arno Hirsch. Congregação Israelita Paulista. São Paulo, 13 de maio de 1940.

\section{Declarações}

- Declaração de José Aron Barmak em cartão distribuído pela Congregação Israelita Paulista durante a Campanha de 1941.

\section{Fotografias}

- Fotografias publicadas no livreto "Que podemos fazer hoje?" distribuído pela Congregação Israelita Paulista em 1941.

- Montagem cm fotografias das crianças na Colônia de Férias de Embaré. Congregação Israelita Paulista. São Paulo, 1942.

- Fotografias das crianças do Lar da Criança Israelita. São Paulo, s/d. 
- Fotografias do grupo de escotismo da Congregação Israelita Paulista. São Paulo, s/d.

- Fotografia das "Tardes de Costura" com as senhoras da Congregação Israelita Paulista. São Paulo, s/d.

- Fotografia da Biblioteca da Congregação Israelita Paulista. São Paulo, s/d.

\section{Informes/Informações}

- Informe da CIP. São Paulo, 6 de novembro de 1939.

- Informações Reservadas para conhecimento da Diretoria e Comissão de Relações Públicas da Congregação Israelita Paulista. s/d.

\section{Listas}

- Lista de Passageiros impedidos de desembarcar no Rio de Janeiro e em Santos do vapor Montevidéu Marú em 14 de janeiro de 1941; Lista dos passageiros impedidos de desembarcar no Rio de Janeiro e em Santos do vapor Serpa Pinto em 4 de agosto de 1941.

- Lista dos passageiros impedidos de desembarcar em Santos do Vapor Uruguai, em 29 de agosto de 1941; Lista dos passageiros impedidos de desembarcar no Rio de Janeiro do vapor Cabo da Buena Esperança, em 25 de setembro de 1941.

- Lista dos passageiros impedidos de desembarcar no Rio de Janeiro do vapor Cabo de Hornos em 20 de outubro de 1941; Lista dos passageiros impedidos de desembarcar em Santos do vapor Cabo de Hornos em 21 de outubro de 1941.

\section{Pareceres}

- Parecer de Pedro Baptista Martins à União (Associação Beneficente Israelita). São Paulo, 4 de agosto de 1939.

- Parecer da Comissão da Juventude da Congregação Israelita Paulista, Departamento Juvenil, sobre a ampliação da Casa da Juventude. São Paulo, 11 de novembro de 1941.

\section{Questionários}

- Questionário - Fragebogen. Congregação Israelita Paulista. São Paulo, 1939.

\section{Rascunhos}

- Rascunho de nota a ser publicada no $\mathrm{n}^{\circ} .101$ do jornal Crônica Israelita. Escrito por Ludwig Lorch. São Paulo, 1942.

- Rascunho de um relatório de Ludwig Lorch a respeito da situação do "JOINT" em São Paulo. São Paulo, s/d.

\section{Relatórios}

- Relatório O que é a Congregação Israelita Paulista? São Paulo, janeiro de 1939.

- Relatório do setor administrativo da Congregação Israelita Paulista sobre as atividades realizadas em 1941. São Paulo, dezembro de 1941. 
- Relatório de Betti Katzenstein: "Sugestão para a Comissão dos Três". São Paulo, 19 de janeiro de 1942.

- Relatório "Situação Financeira do Departamento de Assistência Social - no momento da transferência de fundos da Comissão dos três para a CIP”. São Paulo, 30 de setembro de 1942.

- Relatório da Comissão da Colônia de Férias da Congregação Israelita Paulista para o período de 1942/43. São Paulo, 22 de março de 1943.

- Relatório "En redor a la proyectada United Jewish Appeal em São Paulo", de T. Berelejis, Oficina Latinoamericana del JDC. São Paulo, 8 de fevereiro de 1948.

- Relatório “Cidades Visitadas”. Campanha Pró-sobreviventes JOINT-HIAS-ORT-OSE. São Paulo, 29 de novembro de 1948.

- Relatório sobre as atividades do Departamento de Assistência Social. s/d.

- Relatório: Situação precária de um certo número de refugiados israelitas no Brasil. Congregação Israelita Paulista. São Paulo, s/d.

- Relatório de Ludwig Lorch para a Congregação Israelita Paulista. s/d.

\section{Requerimentos}

- Requerimento de proposta de empréstimo, Congregação Israelita Paulista. São Paulo, s/d.

\section{Telegramas}

- Telegrama de Horácio Lafer, Ludwig Lorch e Paulo Zander para Getúlio Vargas, Presidente do Brasil, e para o Presidente do Conselho de Imigração no Rio de Janeiro. São Paulo, 8 de agosto de 1941.

- Telegrama de Horácio Lafer, Vogal da Congregação Israelita Paulista, para Getúlio Vargas, Presidente do Brasil. São Paulo, 6 de novembro de 1941.

\section{$\underline{\text { Acervos Consultados }}$}

- Fundo DEOPS/SP - Arquivo Público do Estado de São Paulo

- Fundo Lorch - LEER/USP

- Fundos 187, Congregação Israelita Paulista; Fundo Alfred Hirschberg - Arquivo Histórico Judaico Brasileiro. 


\section{ANEXOS}

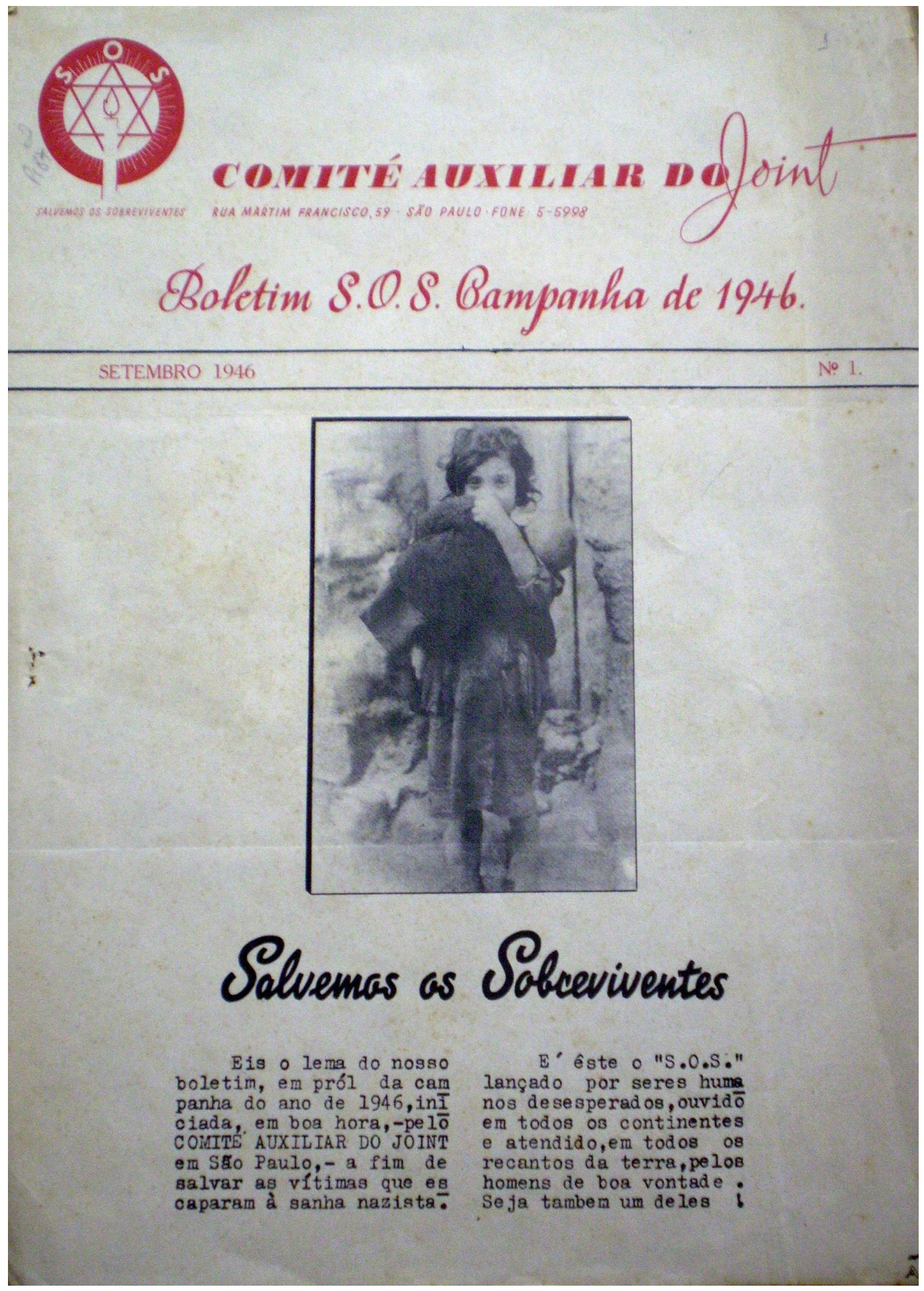

- Boletim no. 1 da Campanha de 1946 do Comitê Auxiliar do JOINT. São Paulo, setembro de 1946. Fundo Alfred Hirschberg/AHJB. 


\section{COMITÉ AUXILIAR DO JOINT NO RIO DE JANEIRO}

AV. FRANKLIN ROOSEVELT, 137

4. ANDAR ‥ SALAS $410 / 12$

Nossa ref.: No. $3729 / 19$

Sua ref.: No. Il!57/R//
FONE : $32 \cdot 6488$

ENDERECYO TELEGRAFICO: RIOCOMITEX

$\mathrm{AO}$

COMITE AUXII,IAR DO JOINT

RUA MARTTM FRANTCISCO 59

SÃO PATTLO / CAPTTAL.

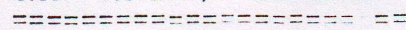

Re: Emissão de vistos brasijeiros pelo Consulado do Brasil em Viena

Prezados Senhores:-

Em resposta ao seu favôr de 79 de Julho n.n., acomnanhado de uma conia da carta que o JotNT de Viena, a 8 de Julho p.r. dirjgiu a VV.SS. com referencia ao assunto acima indicado, temos que mencionar, em forma gera?, que indenendentemente do paiz euronéo em que se encontrar um consulado brasijeiro, o unico,meio que involve ainda uma nequena expetativa de obter um visto, é um valido contrato de trabalho numa profjssão jmnortante nara o nosso paf $z$. 0 reconhecimento deste documento garante, segundo a nossa experiencia, a concessão do visto ao requerente o qual, com o auxilio do JOINT ou da IRO, ou pelos esforços combinados das duas organjzações, poderá seguir o seu caminho ao Prasil.

UItimamente não tivemos mais noticias confirmativas da intervencão do Ministerio das Relações Exteriores em favôr da concessão de vistos brasileiros a pessoas do nosso circulo interessado.

Infelizmente não nos é possivel transmitir a VV.Ss. noticias mais concretas em pról da causa em que ambos estamos interessados e, declarando-nos sempre ao seu dispor, subscrevemo-nos

$s$

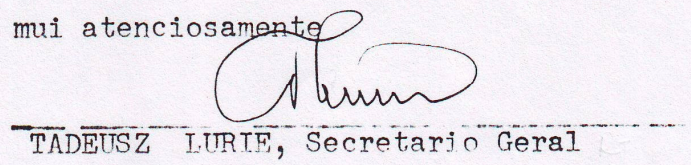

CW/
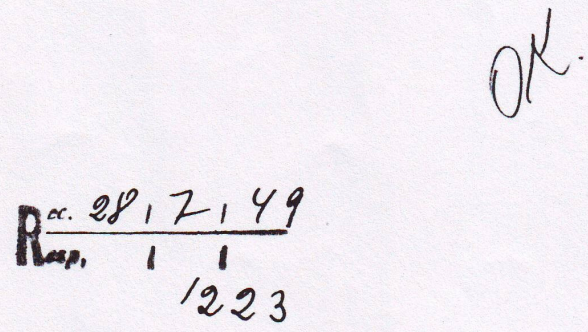

- Carta de Tadeusz Lurie, Secretário Geral do Comitê Auxiliar do JOINT do Rio de Janeiro, para o Comitê Auxiliar do JOINT de São Paulo. Rio de Janeiro, 25 de julho de 1949. Fundo 187/AHJB 


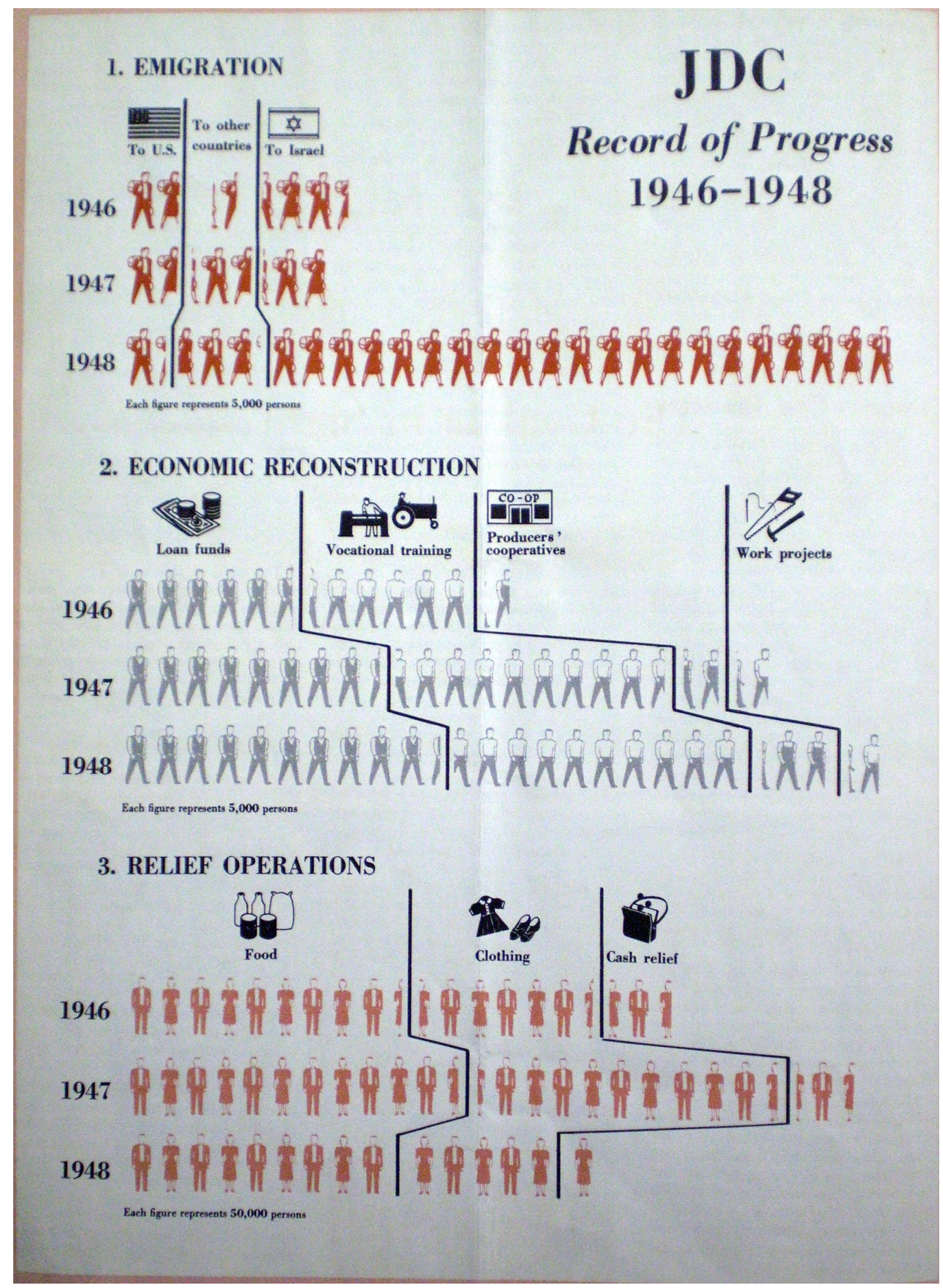

- Panfleto ilustrando o progresso do trabalho do JOINT Distribution Committee de 1946 a 1948. Fundo Alfred Hirschberg/AHJB. 
According to the 3 razilian Law n: 4.166 from Maroh 1942 all axis-nationals had to declare thelr assets in Brazil and had to deliver, according to the amount of their assets 10 - 20 - or $30 \%$ of the avallable assets, such as money, banking-accounts and securities to the "3anco do 3rasil.". These assets are not yet confiscated, but are for the time-being just under secuester. Besides the axis-nationals are superintended vith thelr other assets, and are not allowed to sell real-estate, securities, loans eto. without the pernit of the "Ajânola de Defesa Beononice do Banco do Bras11". The supervision is rather rigorous. The Italians have been exerpted of this lav last year, so that now only German and Japanese nationals are subnitted to this law.

The law considers as Ceman every person, who entered 3 razil with a cerian passport. Therefore the Jewish rofugees from Gemany in their great nejority are also considered Gernans.

Unt1l now all efforts to liberate the Jewish refugees did not succeed. From Harch 1942 on various officlal and non-official steps were taken in this direction. The flrst of these applications was rejected because the Brazilian Govemment at that tine had not the attention to make individual distinctions between Cemans and cemans. Other applications were not directly rejeoted, but delayed or not answered at all. Cenerally the Brazilian high offlolals concemed (anong then 2 Ministers of State) are recognizing that this treatment of the Jevish refugees envolves a great injustice, but they allege that It would be very, difficult to nake a clear distinction between refugees and other.Gemans, It is understood that the Jewish organizations concerned nade several proposals to overcone this dificulty, but until now withou result.

The last application, which was made in September 1945, is still not answered. This application was directed to the President of Brazil, who gave it to the Hinistry of Justice and Internal Affairs. There the referent of the Ministry gave his opinion in a very fayourable way, but in the reantime a new Department was created: the "Conissão de Reparaçoes de Guerra", to which the application was sent. The application is still there, and we heard unofficially that the referent of our case has the opinion that the comission is not competent for this application, as it envolves a question of high politics. It may be that this delay of decidins about this last application is due to the Paris Peace Conference, where the 3razilian Goverment intends to clain a participation in War-reparations.

The Jewish organizations in Brazil, which are concermed with this question, are the "Comité Representativo dos Interesses dos Judeus Alenäes no 3rasil", rua Martins Perreira, 52, Rio de Janeiro and the "Congregąão Israelita

São Paulo, Soptenber 24, 1946

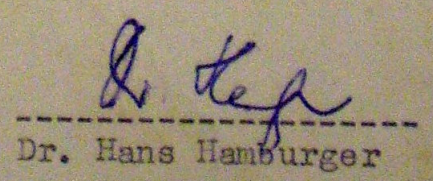

- Carta de Hans Hamburger, do Comitê Representativo do Interesse dos Judeus Alemães no Brasil, para o JOINT. São Paulo, 24 de setembro de 1946. Fundo Lorch/LEER USP. 


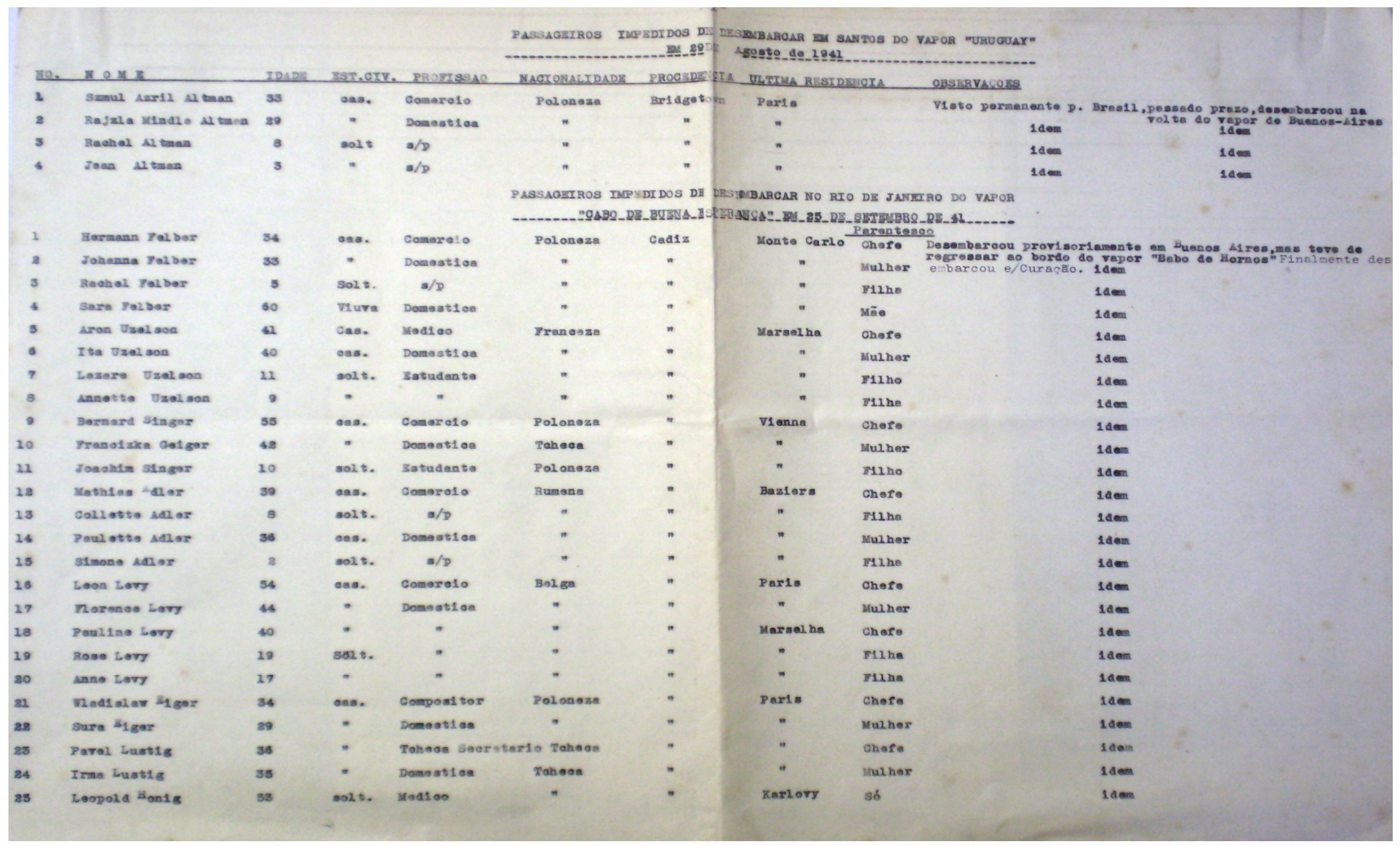

- Lista dos passageiros impedidos de desembarcar em Santos do Vapor Uruguai, em 29 de agosto de 1941; Lista dos passageiros impedidos de desembarcar no Rio de Janeiro do vapor Cabo da Buena Esperança, em 25 de setembro de 1941. Fundo Lorch/LEER - USP. 

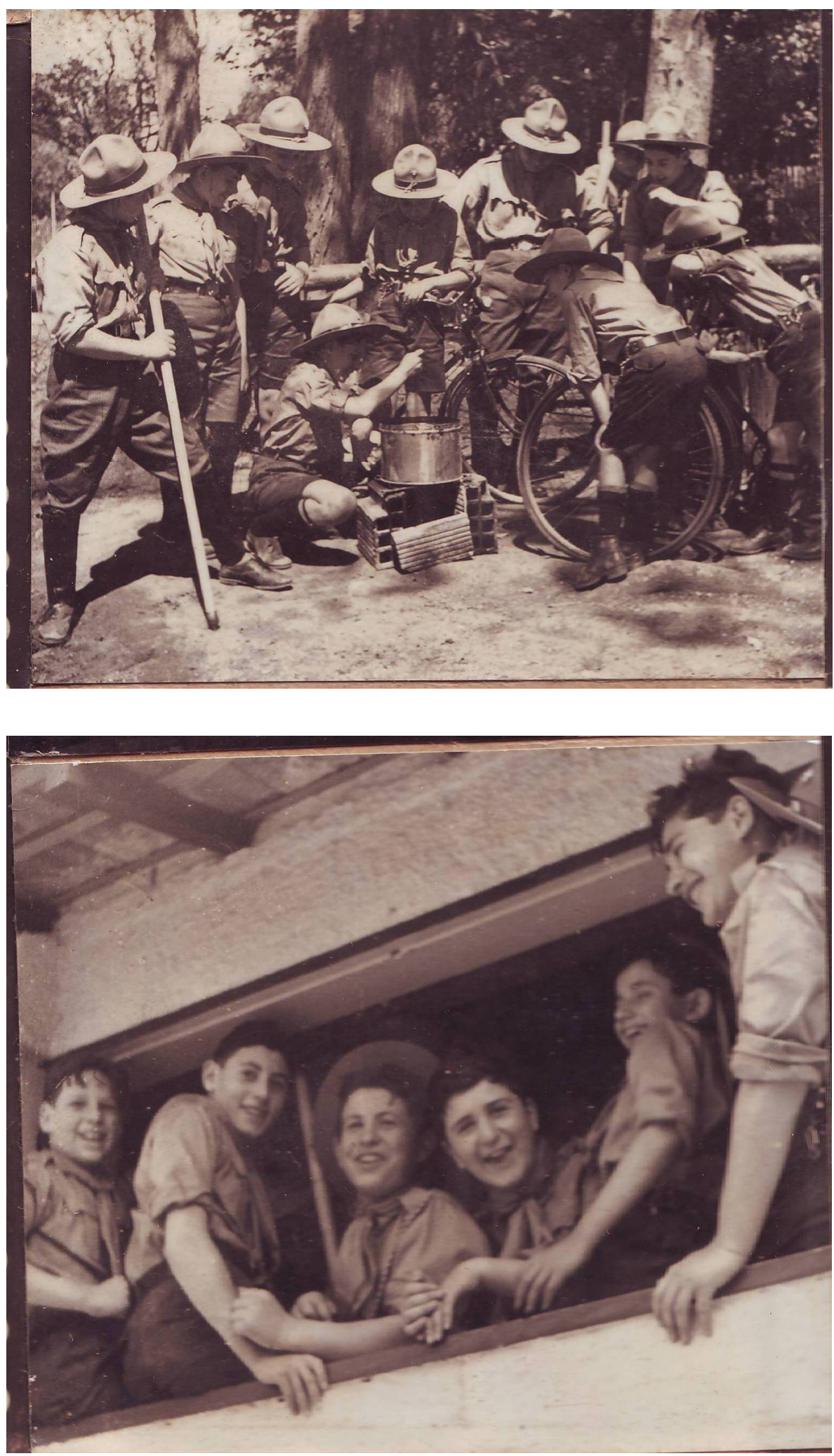

2 Fotografias do grupo de escotismo. Congregação Israelita Paulista. São Paulo, s/d. Fundo Lorch/LEER - USP. 


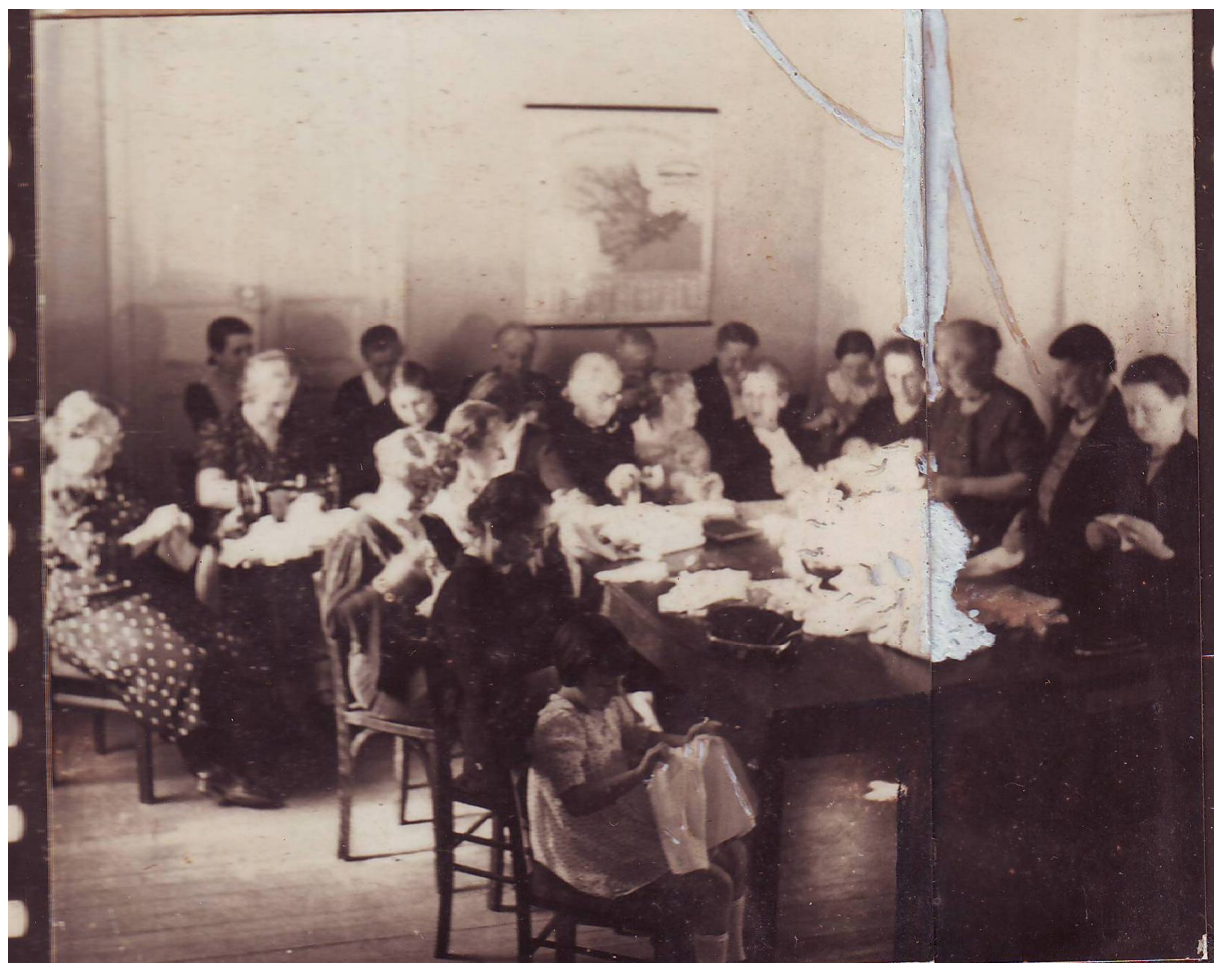

3 Fotografia das "Tardes de Costura" com as senhoras da Congregação Israelita Paulista. São Paulo, s/d. Fundo Lorch/LEER - USP.

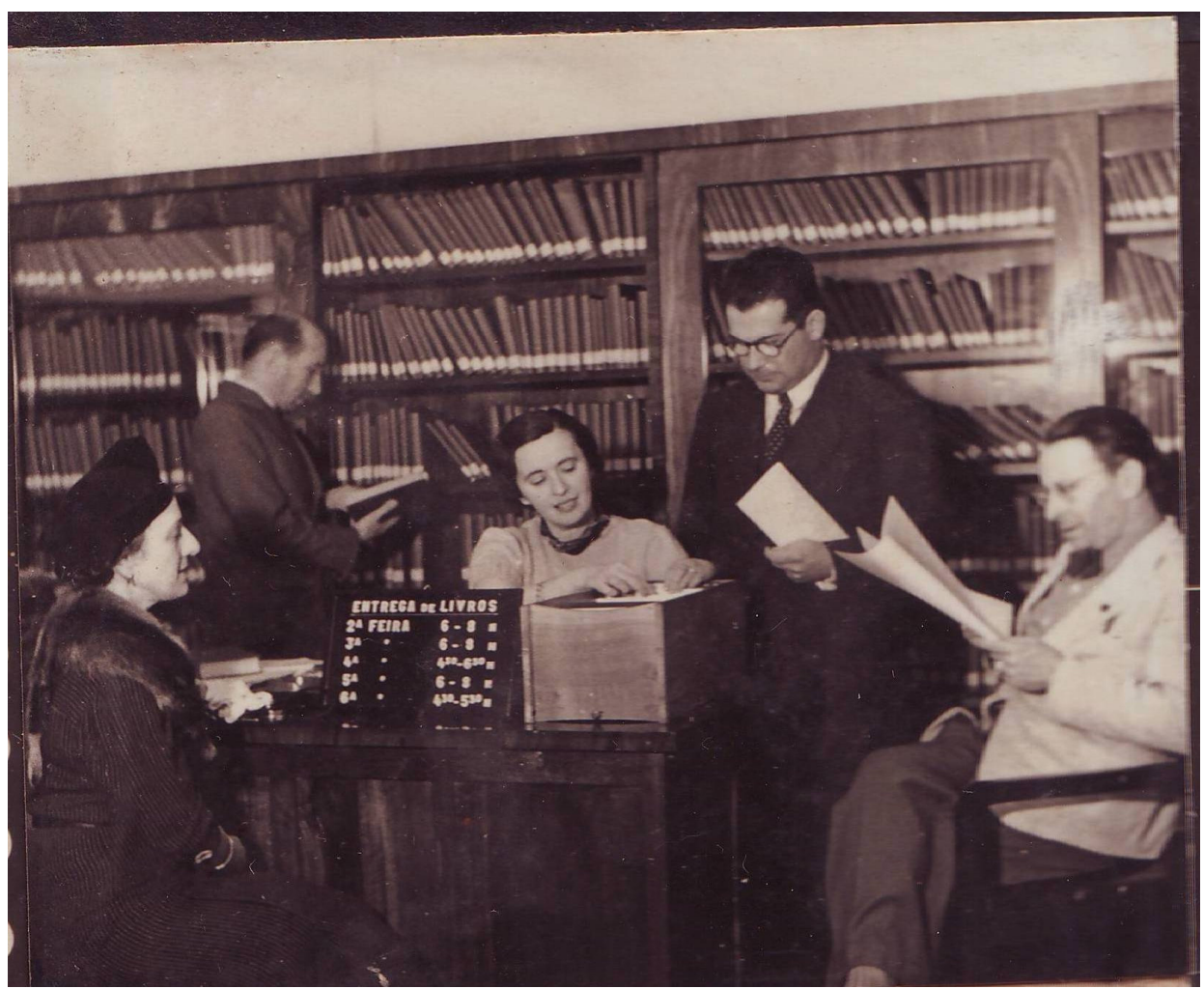

4 Fotografia da Biblioteca da Congregação Israelita Paulista. São Paulo, s/d. Fundo Lorch/LEER - USP. 


\section{BIBLIOGRAFIA}

ARENDT, Hannah Origens do Totalitarismo: Anti-Semitismo, Imperialismo, Totalitarismo. São Paulo: Companhia das Letras, 1989.

BARBOSA, Renata Mazzeo Barbosa. Judeus em Tempos de Guerra. A Comunidade Judaica e os Súditos do Eixo. Pesquisa de Iniciação Cientifica. São Paulo, apoio FAPESP, 2002-2204.

BARTH, Fredrik. Ethnic Groups Boundaries: The Social Organization of Culture Difference. Boston: Little Brown \&Co, 1969.

BIGAZZI, Anna Rosa. In Difesa della Razza - Os judeus italianos refugiados do fascismo e o anti-semitismo do Governo Vargas. Doutorado em Língua Hebraica, Literatura e Cultura Judaica; Departamento de Letras Orientais, FFLCH/USP, 2008.

BRAUDEL, Fernand. Historia e Ciências Sociais. Lisboa: Presença, 1986.

BRUMER, Anita. Identidade em Mudança. Pesquisa Sociológica sobre os Judeus do Rio Grande do Sul. Porto Alegre: Federação Israelita do Rio Grande do Sul, 1994.

CALDEIRA, João Ricardo de Castro. Integralismo e Política Regional: a Ação Integralista no Maranhão (1933-1937). São Paulo: Annablume, 1999.

CANCELLI, Elizabeth. O Mundo da Violência. A Polícia da Era Vargas. Brasília: UnB, 1994.

CANER, Elisa. Judeus-alemães no Brasil - Um Estudo dos Depoimentos das Vitimas do Nazismo. Dissertação de Mestrado apresentada ao Departamento de Língua Hebraica, Literatura e Cultura Judaica. FFLCH/USP, 1996.

CAPELATO, Maria Helena. Estado Novo: Novas Histórias, In: Historiografia Brasileira em Perspectiva. São Paulo: Contexto, 1998.

Multidões em Cena. São Paulo: Papirus, 2001

CARNEIRO, Maria Luiza Tucci O Anti-semitismo na Era Vargas (1930-1945), $3^{\circ}$ edição. São Paulo: Perspectiva, 2001.

. O Veneno da Serpente. São Paulo: Perspectiva, 2003.

Brasil, Um Refúgio nos Trópicos: A Trajetória dos Refugiados do Nazi-

fascismo. São Paulo: Estação Liberdade, 1996.

Cidadão do Mundo: Brasil e a Questão dos Refugiados Judeus (1933-

1948). Tese de Livre-docência apresentada ao Departamento de História: FFLCH/USP. São Paulo, 2001, Perspectiva, no prelo. 
, KOSSOY, Boris. (orgs.). Maria Luiza Tucci Carneiro, Boris Kossoy

(orgs.). A Imprensa Confiscada pelo DEOPS, 1924-1954. São Paulo: Imprensa Oficial/Atliê Editorial, 2003.

(org.). O Anti-semitismo nas Américas. São Paulo: Edusp, 2007.

O Racismo na História do Brasil: Mito e Realidade. São Paulo: Ática, 1994.

Nos Porões do Estado Novo: Vargas demarcou etnias e ideologias exóticas. O Estado de São Paulo, 9.12.2001, p. 5.

COHN, Norman. El Mito de la Conspiracion Judia Mundial. Argentina: Raices, 1969.

CYTRYNOWICZ, Roney. Unibes 85 anos. Uma História de Trabalho Social da Comunidade Judaica em São Paulo. São Paulo: 2001.

A Congregação Israelita dos Pequenos: História do Lar das Crianças da Congregação Israelita Paulista, 65 anos. São Paulo: Narrativa-um, 2003.

Integralismo e anti-semitismo nos textos de Gustavo Barroso na década de 30. Dissertação de Mestrado apresentada ao Departamento da História da FFLCH/USP, 1992.

Guerra sem guerra - a mobilização e o cotidiano em São Paulo durante a Segunda Guerra Mundial. São Paulo: Geração Editorial/Edusp, 2000.

DAVIES, Alan. Antisemitism: An Enduring Problem in Western Society. Canadá: Jcrelations.net, 1996.

DEUTSCHER, Isaac. O Judeu não-judeu e Outros Ensaios. Rio de Janeiro: Civilização Brasileira, 1970.

DIETRICH, Ana Maria e outros. In: CARNEIRO, Maria Luiza Tucci, Inventário DEOPS: módulo I- Alemanha. São Paulo: Arquivo do Estado, 1997.

A Caça às Suásticas. O Partido Nazista em São Paulo na mira da Polícia Política. São Paulo: Humanitas/ FAPESP/ Imprensa Oficial, 2007.

FALBEL, Nachman. Estudos sobre a Comunidade Judaica no Brasil. São Paulo: Federação Israelita do Estado de São Paulo,1984.

Arquivo Histórico Judaico Brasileiro: Inventários dos Fundos das Entidades Beneficentes. São Paulo: Humanitas, 1999.

Manasche: Sua Vida e Seu Tempo. São Paulo: Editora Perspectiva, 1996. 
FAUSTO, Boris (org.). História Geral da Civilização Brasileira, Tomo III: O Brasil Republicano, 3. Sociedade e Política (1930-1964). Rio de Janeiro: Bertrand Brasil, 1996.

História do Brasil. São Paulo: Edusp, 2002.

FERREIRA, Jerusa Pires. O Judeu Errante - a Materialidade da Lenda, in Revista Olhar, São Carlos: UFSCAR, Ano II, nº 3, maio 2000, p.24-30.

FINKELSTEIN, Norman G. A Indústria do Holocausto. Rio de Janeiro: Record, 2001.

GIRARDET, Raoul. Mitos e Mitologias Políticas. São Paulo: Companhia das Letras, 1987.

FISESP. Fisesp 50 anos. Comemorativo ao Aniversário da Federação Israelita de São Paulo. São Paulo: 1996.

FREIDENSON, Marília; BECKER, Gaby Becker (orgs.) Passagem para a América. Relatos da Imigração Judaica para São Paulo. São Paulo: Arquivo do Estado / Imprensa Oficial, 2003.

GAMBINI, Roberto, O Duplo Jogo de Getúlio Vargas: Influência Americana e Alemã no Estado Novo. São Paulo: Símbolo, 1977.

GIDDENS, A. O Estado Nação e a Violência. São Paulo: EDUSP, 1985.

GOFFMAN, Erving. Estigma. Rio de Janeiro: Zahar Editores, 1980.

HEMSI, Silvana. Identidade Judaica: Significados e Pertinência. Um estudo sobre jovens judeus liberais. Tese de Doutorado apresentada ao Programa de Pós em Língua Hebraica, Literatura e Cultura Judaicas. FFLCH / USP, 2002.

HIRSCHBERG, Alice Irene. Desafio e Resposta, a História da Congregação Israelita Paulista, Edição especial por ocasião do quadragenário da Congregação Israelita Paulista. São Paulo: 1976.

IGLICKY, Ilana Rabinovici. A Ética Judaica Inserida no Sistema Educacional como Fator Construtor da Identidade Comunitária: Fatos e Realidades. Dissertação de Mestrado apresentada ao Programa de Pós em Língua Hebraica, Literatura e Cultura Judaicas. FFLCH / USP, 2004.

IOKÓI. Zilda Márcia Gricoli. A Questão Judaica. Diplomacia, Repressão e Resistência no Brasil Contemporâneo. Tese de Livre Docência apresentada ao Departamento de História: FFLCH / USP, 2001.

ISAAC, Jules. Las Raíces Cristianas del Antisemitismo. Buenos Aires: Editorial Paidos, 1966.

JOHNSON, Paul. História dos Judeus. Rio de Janeiro: Imago, 1989. 
KOIFMAN, Fábio. Dom Quixote nas Trevas. Rio de Janeiro: Imago, 2000.

LESSER, Jeffrey. O Brasil e a Questão Judaica. Rio de Janeiro: Imago, 1995.

LEWIN, Helena. Judaísmo: Memória e Identidade (vol. I e II). Rio de Janeiro: UERJ, 1997.

“Os Judeus e seu Compromisso com a Memória”. Revista do Museu

Judaico, Edição comemorativa do $25^{\circ}$ aniversário. Rio de Janeiro, julho de 2002.

LEWISOHN, Luis. O que é a Herança Judaica? Rio de Janeiro: Editora B'Nai B'rith, $\mathrm{s} / \mathrm{d}$.

MEDEIROS, J. A Ideologia Autoritária no Brasil (1930-1945). Rio de Janeiro: FGV,1978.

MILGRAN, Avraham. Os judeus do Vaticano. Rio de Janeiro: Imago, 1994

MIZRAHI, Rachel. Imigração e Identidade. As Primeiras Comunidades Judaicas do Oriente Médio em São Paulo e no Rio de Janeiro. Tese de Doutorado apresentada ao Departamento de História, FFLCH / USP, 2000. Publicada em 2003, São Paulo: Ateliê Editorial.

MOTTA, Rodrigo Patto Sá O Perigo Vermelho. São Paulo: Perspectiva, 2002.

NEHAB, Werner. Anti-semitismo, Integralismo, Neo-nazismo. Rio de Janeiro: Livraria Freitas Bastos S.A., 1988.

OLIVEIRA, Roberto Cardoso. Identidade, Etnia e Estrutura Social. São Paulo: Livraria Pioneira, 1976,

OMEGNA, Nelson. Diabolização dos Judeus. Martírio e Presença dos Sefardins no Brasil Colonial. São Paulo: Record, 1969.

PERAZZO, Priscila Ferreira. O Perigo Alemão e os Mecanismos de Repressão Policial no Estado Novo. São Paulo: Divisão de Arquivo do Estado, Coleção Teses e Monografias, 1999.

Estado, 1997

PINCHERLE, Lívio Túlio. Meus dois Mundos: História da vida de médico judeu ítalobrasileiro. São Paulo: Roswitha Kempf, 1987.

PINKUSS, Fritz. Estudar, Ensinar, Ajudar - Seis décadas de um rabino em dois continentes. São Paulo: Cultura, 1990;

POLIAKOV, Leon. A Causalidade Diabólica I. São Paulo: Perspectiva, 1991. Anti-sionismo ao Anti-semitismo. São Paulo: Perspectiva, 1988. 
POMAR, Pedro Estevam Rocha. A Democracia Intolerante. Dutra, Adhemar e a repressão ao Partido Comunista (1946-1950). São Paulo: Coleção Teses e Monografias Vol. 4, 2002

RATTNER, Henrique. Tradição e Mudança. A Comunidade Judaica em São Paulo. São Paulo: Ática: 1977.

- (org.). Nos Caminhos da Diáspora. Uma Introdução ao Estudo Demográfico dos Judeus. São Paulo: Centro Brasileiro de Estudos Judaicos, 1972.

SENKMAN, "La Política Imigratoria del Primer Peronismo Respecto de Los Refugiados de La Postguerra: Uma Perspectiva Comparada com Brasil, 1945-1954”. In: Gurevich, Beatriz; Escude, Carlos (org.). El Genocídio Ante la Historia y la Natureza Humana. Buenos Aires, Grupo Editor Latinoamericano S.R.L., 1994

SEYFERTH, Giralda. "A assimilação dos imigrantes como questão nacional”. Rio de Janeiro, Scielo.br, abril de 1997.

SORJ, Bila. (org.). Identidades Judaicas no Brasil Contemporâneo. Rio de Janeiro: Imago, 1997.

SCHOLEM, Gershom. De Berlim à Jerusalém. São Paulo: Perspectiva, 1991.

SKIDMORE, Thomas. Brasil: De Getúlio a Castelo, $13^{\circ}$ ed.. São Paulo: Paz e Terra, 2003.

SODRÉ, Nelson Werneck. Memórias de um Escritor -1. Rio de Janeiro: Civilização Brasileira, 1970;

TRACHTENBERG, Joshua. El Dablo y los Judios. Buenos Aires: Editorial Paidos, 1975.

TOTA, Antônio Pedro. O estado novo. São Paulo: Editora Brasiliense, 1987.

VARGAS, Getúlio. A Nova Política do Brasil; Volume V-O Estado Novo, 10 de Novembro de 1937 à 25 de Julho de 1938. Rio de Janeiro: José Olympio.

A Nova Política do Brasil; Volume IV - Retorno à Terra Natal, Confraternização Sul-Americana, A Revolução Comunista: Novembro de 1934 à Julho de 1937. Rio de Janeiro: José Olympio.

VIANNA, Francisco José de Oliveira. Ensaios Inéditos. Campinas: Ed. Unicamp, 1991. Raça e Assimilação. São Paulo: Companhia Editora Nacional, 1932.

WEINBERG, M. F. Histórias Recontadas: Imigrantes Judias Empresárias em São Paulo (1945-1956). Tese de Mestrado apresentada ao Programa de Pós em Língua Hebraica, Literatura e Cultura Judaicas. FFLCH / USP, 2004. 
WIAZOVSKI, Taciana. Bolchevismo e Judaísmo, A Comunidade Judaica sob o Olhar do DEOPS; Módulo VI - Comunistas. Arquivo do Estado/Imprensa Oficial 2001.

O Mito do Complô Judaico-Comunista no Pensamento Autoritário

Brasileiro: Gênese, Difusão e Desdobramentos. Dissertação de Mestrado apresentada ao Programa de Pós em Língua Hebraica, Literatura e Cultura Judaicas. FFLCH / USP, 2005. No prelo pela Associação Editorial Humanitas.

WOLFF, Egon e Frida. Depoimentos: Um Perfil da Coletividade Judaica Brasileira. Rio de Janeiro: Instituto Histórico e Geográfico Brasileiro, 1988.

Guia Histórico da Comunidade Judaica de São Paulo. São Paulo: BNei Brith S/C, 1988.

Campos: Ascensão e Declínio de uma Coletividade. Rio de Janeiro: ERCA Editora, 1986.

Fatos Históricos e Mitos: da História dos Judeus no Brasil. Rio de Janeiro: Xenon Editora e Produtora Cultural, 1996.

ZVEIBIL, Silvia Jane. Identidade Étnica Judaica. Caracterização e Processo de Constituição. Tese de Doutorado apresentada ao Departamento de Ciências Sociais. FFLCH/USP, 1980. 